\title{
DINÂMICA POPULACIONAL CANINA E A \\ PERSISTÊNCIA DA RAIVA NA CIDADE DE RECIFE (PE), \\ NORDESTE DO BRASIL, 1987-1997
}

\section{ANTÔNIO DUARTE DE LIMA JƯNIOR}

Tese de Doutorado apresentada ao Departamento de Epidemiologia da Faculdade de Saúde Pública da Universidade de São Paulo, para obtenção do grau de Doutor.

Área de concentração:

Epidemiologia

ORIENTADOR: PROF. DR. EDUARDO MASSAD

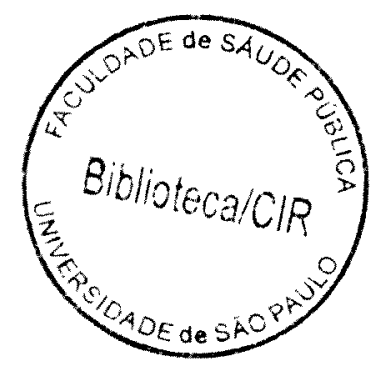

São Paulo

1999 
Autorizo, exclusivamente para fins acadêmicos e científicos, a reprodução total ou parcial desta tese, por processos fotocopiadores.

Assinatura:

23 de Janeiro de 1999

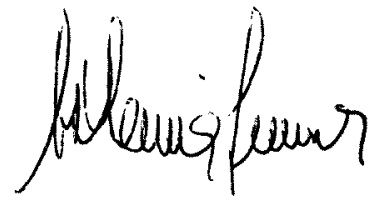

$$
38499199 \text { doe }
$$


Este trabalho é dedicado às minhas filhas

\section{JÚLIA e ANA CAROLINA.}




\section{AGRADECIMENTOS}

O trabalho "Dinâmica Populacional Canina..." foi resultado da parceria entre Instituições e Pessoas, a todos cabendo os méritos pelas conquistas.

Citamos abaixo:

Centro de Vigilância Animal da Prefeitura da Cidade de Recife, e particularmente

$\checkmark$ Dr. Amaury Pereira

$\checkmark$ Médicos Veterinários: Doutores Agrício B. Santos Filho, Carlos, M. Edwis T. Emílio, Eunice Gonçalves, Geraldo V. Andrade Filho.

$\checkmark$ Funcionários do canil, da vacinação, pessoal técnico e de apoio, em especial a sra. Antônia.

Centro de Controle de Zoonoses do Municipio de São Paulo, e particularmente

$\checkmark$ Pessoal do Laboratório de raiva, em especial dra. Elizabeth Amatuzzi da Costa Aguiar, Luzia Fátima Alves Martorelli e Marilene Fernandes de Almeida.

$\checkmark$ Pessoal do Departamento de Recursos Humanos

$\checkmark$ Pessoal dos Setores de Controle de Raiva

Estudantes do Curso de Medicina Veterinária da UFRPE, e graduados que participaram da equipe de trabalhos de campo:

$\checkmark$ Alberto, Ana Magna, Domício, Emerson, Giovana, Karla, Ladjane, Luciana, Rondon, Simone, Wellington. Excelente turma, para o que der e vier.

Secretaria de Saúde do Estado de Pernambuco, em particular ao Dr. Francisco Duarte.

$I B G E$

LAPA / Ministério da Agricultura

FACEPE, que financiou parte deste trabalho.

À Arca Brasil, CNCZAP/FNS, Instituto Pasteur/SP, OPAS e Secretaria de Saúde do Ceará, e em particular aos Doutores Francisco Anilton Alves Araújo, Luiz Elias Bouhid de Camargo, Marco Ciampi, Miguel Angel Genovese, Neide Yumie Takaoka, Nélio Batista de Morais e Rita de Cássia Garcia, pelo apoio para a divulgação do trabalho em diferentes reuniões.

Aos amigos do DMV / UFRPE Doutores Tomoe Noda Saukas, Lêucio Câmara Alves e Alberto Neves Costa, pela orientação inicial e pela ajuda na preparação dos Resumos.

À amiga Nélida Schmidt Fornes, colega de curso, sempre presente, atenciosa e prestativa. Mais que uma colega, uma amiga de ouro.

Ao pessoal da Biblioteca da Faculdade de Saúde Pública da USP, pela assistência.

Aos meus Professores da Faculdade de Saúde Pública da Universidade de São Paulo

Menciono em particular, pelas contribuições, orientação, e ainda, pela confiança e apoio:

$\checkmark$ Professor Dr. Eduardo Massad-FM/USP, o meu orientador

$\checkmark$ Professora Dra. Nilza Nunes da Silva-FSP/USP

Cabe ainda o registro dos nossos agradecimentos à população de entrevistados da cidade de Recife, pela atenção e apoio oferecidos.

Antecipadamente, deixo registrada a minha preocupação com o eventual esquecimento de pessoas que colaboraram conosco, pois estas foram muitas. A elas, as minhas desculpas pelo lapso de memória, e os meus sinceros agradecimentos por terem nos ajudado incondicionalmente. 


\section{RESUMO}

Lima Júnior, A.D. Dinâmica populacional canina e a persistência da raiva na cidade de Recife / PE, Nordeste do Brasil, 1987-1997. São Paulo; 1999. [Tese de Doutorado Faculdade de Saúde Pública da USP]

Objetivo. A raiva canina é endêmica em Recife, apesar de existirem atividades de controle. Por este motivo, realizou-se estudo para identificar fatores relacionados à persistência da raiva - com ênfase na ecologia populacional canina, e avaliar o potencial de diferentes medidas de controle. Métodos. Foram realizados: estudo transversal em amostra de 1296 domicilios em 1996, com pesquisa de anticorpos contra raiva em 320 cães; estudo na campanha de vacinação de 1995; pesquisa de anticorpos em 315 cães capturados pela Prefeitura (1995-1996); estudo descritivo e análise de séries temporais da raiva canina (19871997); e simulações numéricas com modelo matemático deterministico. Resultados. Aproximadamente $80 \%$ das vacinações ocorrem em campanha, onde 23,8 \% são primovacinados; $77 \%$ dos cães não vacinados eram filhotes ou não nascidos na última campanha. As coberturas oscilaram entre 60 e $75 \%$ desde 1987 a 1997. Recife teve 522 cães $/ \mathrm{km}^{2}$ (204 a 1324) e 9,14 habitantes por cão $(8,39$ a 11,23). Existiram elevadas fecundidade, natalidade e mortalidade. Apenas $60,7 \%$ dos animais eram totalmente restritos. Títulos de anticorpos, idade e número de vacinações apresentaram correlação positiva. $32 \%$ dos cães com domicilio e $14,5 \%$ dos cães capturados apresentaram títulos $\geq 0,5 \mathrm{UI} / \mathrm{ml}$. A freqüência relativa de casos de raiva diminuiu nos animais a partir de 4 anos. Em setores pobres os cães tenderam a ser mais jovens e menos restritos, e havia densidades populacionais mais elevadas. Conclusões. A elevada densidade de suscetiveis favorece a persistência da raiva canina. Esta é sazonal em função do crescimento progressivo dos suscetiveis na população, após as campanhas de vacinação, ocasionado pela elevada renovação populacional e perda de imunidade. $O$ incremento na imunização efetiva e a diminuição da idade média à primeira vacinação (atualmente 10 meses), são as medidas com maior potencial de êxito para eliminação da raiva.

Descritores: RAIVA, epidemiologia. ESTUDOS TRANSVERSAIS. MODELOS TEÓRICOS. CÃES. ANTICORPOS. 


\section{SUMMARY}

Lima Júnior, A D. Dinâmica populacional canina e a persistência da raiva na cidade de Recife / PE, Nordeste do Brasil, 1987-1997. [Dog population dynamics and the persistence of rabies in the City of Recife, State of Pemambuco, Northeast of Brazil, 1987-1997]. São Paulo (BR); 1999. [Tese de Doutorado - Faculdade de Saúde Pública da Universidade de São Paulo].

Objective. Despite existing control efforts, canine rabies is endemic in Recife. For this reason a study was held to identify the factors related to rabies persistence - stressing on canine populational ecology and the assessment of potential differences of control measures.

Methods. Cross-sectional studies were made in 1296 homes in 1996, researching rabies antibodies in 320 dogs; during the 1995 vaccination campaign, as well as in 315 dogs captured by the township (1995-1996); a descriptive study and time series analysis of canine rabies (1987-1997); and also numerical simulation by mathematical deterministic model. Results. Aproximately $80 \%$ of vaccinations occured during campaign, $23,8 \%$ being primovaccinated; $77 \%$ of non-vaccinated dogs were puppies or not yet born at the last campaign. The coverages varied between 60 and $75 \%$ from 1987 to 1997 . Recife had 522 dogs $/ \mathrm{km}^{2}$ (204 to 1324) and 9,14 inhabitants per dog $(8,39$ to 11,23$)$. There were high fertility, birth and mortality rates. Only $60,7 \%$ of animals were totaly restricted. Antibody titers, ages and vaccination numbers presented positive co-relation. $32 \%$ of home dogs and $14,5 \%$ of captured ones, presented titers $\geq 0,5 \mathrm{IU} / \mathrm{ml}$. The relative rabies frequency decreased in animal ages from 4 years on. In poor areas, dogs tended to be younger and less restricted and there were higher population densities. Conclusions. The high density of liable dogs enables canine rabies persistence. This is seasonal due to progressive growth of liable dogs among the canine population after vaccination campaigns, due to high populational renovation and immunity loss. The increase of effective immunization and decrease in average age at the first vaccination (now 10 months), are measures of greater success towards elimination of rabies.

Descriptors: RABIES, epidemiology. CROSS-SECTIONAL STUDIES. MODELS, THEORETICAL. DOGS. ANTIBODIES. 


\section{ÍNDICE}

1 INTRODUÇÃO

1.1 Antecedentes 1

1.2 Revisão de Literatura 2

1.2.1 Breve história da raiva 2

1.2.2 Aspectos históricos da raiva em Pernambuco ___ 6

1.2 .3 A doença __ 9

1.2.4 Populações caninas, ecologia, epidemiologia e o controle da raiva ___ 15

1.2.5 Vacinas e Vacinação anti-rábica ____ 26

1.2.6 Avaliação da vacina inativada produzida em cérebro de camundongos lactentes (VCCL) em condições naturais ___ 32

1.2.7 A vacinação anti-rábica canina no Brasil e o Programa Nacional de Profilaxia da Raiva ___ 36

1.3 Caracterização do problema da raiva na cidade de Recife ___ $\mathbf{4 0}$

2 OBJETIVOS _ 52

2.1 Objetivos Gerais: ___ 52

2.2 Objetivos Específicos:

3 PROCEDIMENTOS METODOLÓGICOS _ 53

3.1 Estudo transversal da população canina vacinada na campanha de vacinação anti-rábica de Recife, 1995: 53

3.2 Estudo transversal da população canina em domicílios da cidade de Recife, 1996: 55

3.2.1 Planejamento do estudo transversal e atividades preparatórias __ 55

3.2.2 Plano de amostragem:

3.2.3 Entrevistas e colheita de sangue dos cães _ 58

3.2.4 Informações complementares sobre o estudo transversal ___

3.3 Estudo sorológico dos cães capturados pelo CVA/PCR, 1995-1996: __ 60

3.4 Exames Sorológicos 61

3.4.1 Processamento e armazenamento das amostras ___ 61

3.4.2 Transporte ___ 62

3.4.3 Testes sorológicos _ 62

3.5 Modelagem matemática: ___ 64

3.5.1 Características e suposições do modelo ___ 64 
3.5.2 Etapas da Modelagem: 68

3.6 Análises estatísticas: 72

3.6.1 Métodos estatísticos

3.6.2 Softwares

3.6.3 Análise multivariada 72

3.6.4 Estudo da estrutura etária, mortalidade e natalidade da população canina $-75$

3.6.5 Análise de séries temporais aplicada aos casos de raiva canina na cidade de Recife: 79

4 RESULTADOS 83

4.1 Quem respondeu às entrevistas: 83

4.2 Características diferenciais entre as Unidades Primárias de Amostragem (UPA) 85

4.3 Tamanho e densidade da populaçåo canina de Recife / PE, 1996 86

4.4 Características da população canina de Recife / PE, 1996 88

4.5 Estrutura etária, natalidade e mortalidade na população canina de Recife / PE, 1996 94

4.5.1 Estrutura etária ___ 94

4.5.2 Natalidade ___ 95

4.5.3 Mortalidade ___

4.6 Caracterização dos casos de raiva canina em Recife, PE 100

4.7 Análise temporal dos casos de raiva canina de Recife __ 105

4.7.1 Análise de tendência: __ 105

4.7.2 Índices estacionais: 106

4.7.3 Componente ciclica: 109

4.8 Avaliação da imunização anti-rábica __ 111

4.8.1 Campanha de vacinação anti-rábica, Recife / PE, $1995 \_112$

4.8.2 Estudo transversal __ 113

4.8.3 Estudo dos animais capturados no Centro de Vigilância Animal da Prefeitura da Cidade de Recife

4.9 Resultados das Simulações

4.9.1 Influência da vacinação sobre a dinâmica da raiva

4.9.2 Influência da perda de imunidade sobre a dinâmica da raiva 123

4.9.3 Influência da mortalidade sobre a dinâmica da raiva 124

5 Discussão 
5.1 Aspectos de representatividade e confiabilidade da amostra

5.2 A amostra e suas características : perfil geral dos domicilios, seus habitantes e aspectos relevantes para o estudo

5.3 Características diferenciais entre as Unidades Primárias de Amostragem 131

5.3.1 Criação de cães: _ـ 131

5.3.2 Abundância de "cães de rua" ___ 132

5.3.3 Prevalência de cães dependentes e de cães restritos _ 133

5.3.4 Cães vacinados contra raiva __ 135

5.4 População canina _ـ 137

5.4.1 Tamanho e densidade ___ 137

5.4.2 Origem dos cães ___ 138

5.4.3 Distribuição quanto ao sexo _ـ 139

5.4.4 Raças de cães _ـ 140

5.4.5 Finalidade dos cães _ـ_ 140

5.4.6 Natalidade e mortalidade __ 141

5.4.7 Estrutura etária __ 144

5.5 Campanha de vacinação anti-rábica ___ 147

5.6 Casos de Raiva __ 150

5.7 Imunidade__ 153

5.7.1 Aspectos relacionados à técnica sorológica ___ 153

5.7.2 Eficiência da imunização anti-rábica __ 155

5.8 Estacionalidade___ 161

5.9 A dinâmica da doença

6 Conclusões ___ 172

$7 \quad$ REFERENCIAS

$8 \mathrm{ANEXOS}$

8.1 ANEXO I - Definição operacional das variáveis utilizadas no trabalho ___ 2

8.2 ANEXO II - Fórmulas para determinação do tamanho da amostra, objetivando a estimativa de médias e proporções populacionais (Stevenson, 1986) 5

8.3 Anexo III - Questionário da CAMPANHA DE VACINAÇÃO ANTIRÁBICA DA CIDADE DO RECIFE 7 
8.4 Anexo IV - QUESTIONÁRIO DO DOMICÍLIO 8

8.5 Anexo V - QUESTIONÁRIO INDIVIDUAL DOS ANIMAIS 9

8.6 Anexo VI - Correlação entre as variáveis censitárias 10

8.7 Anexo VII - Indicador de saúde da população canina 11

8.8 Anexo VIII - Metas educacionais e sociais estabelecidas para o projeto 12 


\section{LISTA DE FIGURAS}

Figura I: distribuição dos casos de raiva na cidade de Recife, segundo os bairros, entre os anos de 1991 e 1997. 41

Figura 2: Homem arremessando cão morto no Rio Capibaribe (liha Joana Bezerra). 43

Figura 3: proporção de cobertura de vacinação ao nascer requerida para interromper a transmissão da doença 48

Figura 4: diagrama representativo do modelo matemático utilizado para as simulações numéricas relacionadas à raiva na cidade de Recife / PE. 66

Figura 5: quem foi entrevistado, em estudo da população canina de Recife / PE, 1996 83

Figura 6: pirâmide etária de uma amostra de cães vacinados em campanha de vacinação antirábica, Recife / PE, 1995 94

Figura 7: pirâmide etária de cães em uma amostra de domicílios de Recife / PE, 1996 94

Figura 8: percentual de partos em cães de uma amostra de domicilios de Recife / PE; avaliação retrospectiva de 12 meses no primeiro trimestre de 1996. 96

Figura 9: curva de mortalidade proporcional para cães de Recife / PE, 1995-6___ 98

Figura 10: coeficiente de mortalidade em cães de Recife / PE, 1995-6. (x 1000) 100

Figura 11: número de casos de raiva canina diagnosticados laboratorialmente na cidade de Recife entre os anos de 1974 e 1997.

Figura 12: casos de raiva canina na cidade de Recife, entre os anos de 1987 e 1997;

observados e esperados (baseado em dados de tendência e estacionalidade. 106

Figura 13: indices estacionais para raiva canina em Recife / PE, entre os anos de 1987 e 1997. 107

Figura 14: indices estacionais para casos de raiva canina em Recife / PE (1987 a 1997) e partos em cadelas (\%) 108

Figura 15: relativos de ciclo para casos de raiva canina em Recife / PE, 1987 a 1997. 109

Figura 16: influência percentual dos efeitos ciclicos sobre os casos de raiva canina em Recife /

PE, 1987 a 1997. 110

Figura 17: cobertura de vacinação em campanhas de vacinação anti-rábica na cidade de Recife, 1987-1997 111

Figura 18: distribuição de frequiência dos titulos de anticorpos contra raiva, segundo a idade, em cães de uma amostra de domicílios de Recife / PE, 1996 116

Figura 19: proporção de animais com titulos $\geq 0,5 \mathrm{UI} / \mathrm{ml}$ (boa resposta), segundo a idade em meses, em cães de uma amostra de domicilios, Recife / PE, 1996 117

Figura 20: distribuição de freqüência dos títulos de anticorpos contra raiva, segundo a faixa etária presumida, em cães capturados pelo Centro de Vigilância Animal da P.C.R., Recife / PE, 1996 119 
Figura 21: proporção de animais com título $\geq 0,5 \mathrm{UI} / \mathrm{ml}$, segundo a faixa etária presumida, em uma amostra de cães capturados pelo Centro de Vigilância Animal da P.C.R., Recife / PE, 1996.

Figura 22: curva ajustada de anticorpos contra raiva em cães de Recife /PE, 1996 121

Figura 23: relação entre a taxa de vacinação anti-rábica e o número de animais infectados (por 100.000 cães), Recife / PE, 1996.

Figura 24: relação entre a idade média à primeira vacinação contra raiva, e a taxa de infecção pela doença, Recife / PE, 1996

Figura 25: efeito da taxa de perda de imunidade contra raiva sobre o número de animais infectados (por 100.000 cães), Recife / PE, 1996

Figura 26: efeito da mortalidade sobre o número de casos de raiva (por 100.000 cães), com valor de $\beta$ variável, Recife / PE, 1996

Figura 27: Cães acasalando livremente na rua, em municipio da Região Metropolitana de Recife.

Figura 28: cobertura de vacinação anti-rábica e eliminação de cães errantes na cidade de Recife, no periodo de 1987 a 1997.

Figura 29: Evolução do indice de desenvolvimento humano segundo estados do Brasil, 19701996.

Figura 30: percentual de amostras de origem canina positivas para raiva, segundo o mês, entre os anos de 1996 e 1997. 165

Figura 31: indices estacionais para raiva, percentual de partos em cadelas e percentual de amostras positivas em exame laboratorial para raiva, Recife, $P E$. 166 


\section{LISTA DE TABELAS}

Tabela 1: Casos positivos de raiva no Nordeste Brasileiro entre 1965 e 1972. 8

Tabela 2: varióveis, parâmetros, e variáveis de controle utilizados no modelo: 67

Tabela 3: Variáveis utilizadas como fatores de classificação (dependentes) e respectivas definições. 73

Tabela 4: Variáveis independentes e respectivas definições. 74

Tabela 5: modelos finais da análise discriminatória aplicada a diferentes varióveis dependentes, em estudo da população canina de Recife / PE, 1996.

Tabela 6. estimativas de parâmetros da população canina, a partir de dados de uma amostra de domicilios e de dados oficiais, em estudo da população canina de Recife / PE, 1996

Tabela 7: caracterização dos cães quanto a sexo, estado reprodutivo, origem e idade de aquisição, em uma amostra de domicilios, Recife / PE, 1996 88

Tabela 8: forma de aquisição dos cães em uma amostra de domicilios de Recife / PE, 1996 89

Tabela 9: finalidade dos cães em uma amostra de domicilios de Recife / PE, 1996 90

Tabela 10: categorização dos cães, quanto à restrição e dependência, em uma amostra de domicilios de Recife / PE, 1996

Tabela 11: classificação dos cães em uma amostra de domicilios de Recife / PE, 1996 92

Tabela 12: razão entre o numero de habitantes por cães e por gatos, segundo a região politico administrativa, em uma amostra de domicilios de Recife / PE, 1996 93

Tabela 13: mortalidade proporcional em cães, segundo faixa etária, Recife / PE, 1995-6 97

Tabela 14: Mortalidade Proporcional (\%) em cães, segundo a causa presumida, e segundo a causa presumida por grupo etário. Recife / PE 1995-6.

Tabela 15: Coeficiente Geral de mortalidade e coeficientes especificos por causa presumida, segundo faixa etária, em cães, Recife / PE 1995-6. (x 1000 cães)

Tabela 16: casos de raiva canina na cidade de Recife / PE, segundo bairro e RPA, entre os anos de 1993 e 1997.

Tabela 17: total de casos de raiva canina na cidade de Recife / PE, segundo a RPA, entre os anos de 1993 e 1997

Tabela 18: situação de domiciliação dos cães com diagnóstico laboratorial de raiva, entre os anos de 1993 e 1997, Recife / PE. 103

Tabela 19: casos de raiva diagnosticados laboratorialmente na cidade de Recife / PE, entre 1993 e 1997, segundo o grupo etário e situação de vacinação contra raiva. 104

Tabela 20: situação de vacinação anti-rábica em cães de uma amostra de domicilios de Recife

/PE, 1996

Tabela 21: composição de grupos etários de cães com proprietários em diferentes áreas geográficas 
Tabela 22: casos de raiva diagnosticados laboratorialmente (com idade registrada), entre 1993 e 1997, segundo o grupo etário, e freqüência de grupos etários de cães em Recife.

Tabela 23: correlação entre as variáveis dependentes e independentes do estudo: coeficiente de correlação (probabilidade $<n$ ) 10

Tabela 24: cálculo do indicador de saúde para a população de cães de Recife / PE 11 


\section{INTRODUÇÃO}

\subsection{Antecedentes}

No ano de 1993, a Universidade Federal Rural de Pernambuco (UFRPE) foi convidada a participar de uma reunião da Comissão Estadual de Profilaxia da Raiva do Estado de Pernambuco (CEPR). Fomos indicados para a tarefa, pelo Departamento de Medicina Veterinária, e aceitamos o convite. Até aquele momento, estranhamente, não tínhamos conhecimento de que representantes do único curso de Medicina Veterinária do estado de Pernambuco, tivessem participado das atividades da citada comissão

Durante esta reunião, da qual participaram inúmeros representantes de órgãos oficiais com sede no Estado de Pernambuco, tomamos conhecimento de diversos aspectos ligados ao controle da raiva em Pernambuco, e dois deles nos chamaram maior atenção.

$\mathrm{O}$ primeiro desses aspectos, referia-se à falta de uma maior integração entre as instituições que colaboravam com as atividades de controle da raiva. Alguns representantes, por repetidas vezes, não compareceram às reuniões da CEPR, apesar dos convites enviados pela comissão. $\mathrm{O}$ outro aspecto, correspondia à falta de avaliações mais particulares dos resultados das campanhas de vacinação anti-rábica, atividade prioritária do programa de controle da raiva. As avaliações se limitavam principalmente ao levantamento de números de animais vacinados em diferentes regiões da cidade.

Em função da constatação desta realidade, tomamos duas iniciativas:

Na primeira delas, realizamos uma mesa redonda na UFRPE, com a participação de representantes da CEPR, técnicos da área de controle de zoonoses dos municípios da Região Metropolitana de Recife (RMR), e uma platéia de mais de 300 pessoas, principalmente estudantes de Medicina Veterinária e Médicos Veterinários. Um dos frutos dessa reunião, além da amplificação das discussões sobre o problema da raiva, foi o início de pleitos que resultaram na participação de Médicos Veterinários no processo de seleção para curso de Residência em Saúde Pública do Núcleo de Estudos em Saúde Coletiva / Fiocruz / Recife, até então destinados apenas a outros profissionais da área de Saúde.

A outra delas, foi a realização de um estudo preliminar com o intuito de avaliar alguns aspectos da campanha de vacinação anti-rábica no ano de 1993. Neste ano, a UFRPE participou mais diretamente das atividades de treinamento para a campanha, não só mediante a participação de estudantes do curso de Veterinária, supervisores das atividades na campanha, mas também na forma de um treinamento teórico mais detalhado. 
A partir de então, começamos a nos envolver mais com o problema da raiva, em particular na cidade de Recife, a qual centralizava algumas atividades de controle da raiva na RMR, e dispunha de registros mais sistemáticos das atividades desenvolvidas. Os resultados da avaliação fizeram com que tomássemos conhecimento de inúmeras deficiências nas atividades de controle da raiva.

Estas experiências, e o nosso crescente interesse no envolvente universo do conhecimento sobre a raiva, resultaram na decisão de realização de um trabalho de pesquisa, com o objetivo de aprofundar os nossos conhecimentos sobre o problema da raiva na cidade de Recife, as suas causas e possibilidades de intervenção, tema da presente Tese de Doutoramento. Por não serem indispensáveis à caracterização do projeto, no Anexo VIII foram incluídas as metas educacionais e sociais estabelecidas para o projeto.

\subsection{Revisão de Literatura}

\subsubsection{Breve história da raiva}

A raiva é provavelmente a infecção com registro mais antigo. A palavra tem origem no sânscrito, a partir da palavra "rabbahs" que significa "fazer violência". Esta refere-se ao período védico da Índia (30 séculos a.C.), quando o deus da morte foi descrito em companhia de um cão, seu constante companheiro e emissário da morte. A primeira descrição da doença data de 23 séculos a.C., em um código prémosaico da Babilônia. A associação do cão com a doença já era conhecida no Egito antigo, quando o deus Sirius foi imaginado na forma de um cão furioso, e a raiva parecia ser prevalente no fimm do verão ( $\mathrm{Fu}, 1997)$.

Uma descrição detalhada da história da raiva é apresentada por Steele (1975). As citações da doença remontam à história antiga, e os cães raivosos estão presentes em episódios associados a personagens famosos e até divindades, como é o caso dos Gregos, que tinham um deus (Aristaeus, filho de Apolo) para contra atacar os efeitos da raiva. Lyssa ou Lytta, como era chamada a raiva pelos Gregos, significava loucura, e a doença no homem era descrita como hidrofobia, na qual o individuo era atormentado ao mesmo tempo pela sede e pelo temor à água. 
Acredita-se que o primeiro registro de descrição da raiva canina tenha sido feito por Demócrito, aproximadamente 500 anos antes de Cristo. Os animais doentes ficavam bastante irritados e os animais mordidos pelos doentes adoeciam. Um escritor Romano descreveu a infectividade da saliva dos cães raivosos, onde o material infeccioso é caracterizado como um veneno ou "virus" em Latim. Plínio menciona uma outra causa para a doença, um verme da língua do cão, e a prevenção da doença, acreditava-se, era obtida através do corte de uma estrutura da língua (frenum linguae), na qual pensava-se estar localizado o verme. Essas crenças persistiram até o século 19, quando Pasteur demonstrou a causa da raiva (Steele, 1975).

Até o período dos estudos de Pasteur, a história da raiva em diferentes épocas e culturas é rica em crenças e nas mais diversas tentativas de tratamento das pessoas mordidas por cães raivosos. Muitos são os escritos sobre episódios envolvendo animais e pessoas doentes. As epizootias eram raras até a idade média. A maioria dos episódios envolviam mordidas únicas por cães raivosos, e algumas vezes por lobos, texugos, raposas e ursos. O primeiro grande surto de raiva foi descrito na Francônia no ano 1271. Lobos raivosos invadiram cidades e vilarejos, atacando as criações e pessoas. Ao menos trinta pessoas mordidas pelos lobos morreram. Na América do Sul em 1750, foi descrito um tipo de loucura que afetava os cães, matando-os em 2 a 3 dias caso eles não fossem mortos (Steele, 1975).

No século 18 as autoridades mataram milhares de cães na França, Itália e Espanha. Neste mesmo século, a raiva já causava alarme em cidades da América do Norte. Em países da América Latina e Caribe ocorreram episódios da doença, quer na forma paralítica ou furiosa. Muitas pessoas eram mordidas e morriam, assim como animais domésticos, como eqüinos, suinos e caprinos. No século 19 a doença estava disseminada na Europa, onde também ocorreram grandes surtos de raiva em raposas. Neste período, a doença já era prevalente na Ásia e também ocorreu pela primeira vez no Peru e Chile, onde diversas pessoas e animais morreram. Em La Plata, na Argentina, a doença foi introduzida em 1806 através de cães para prática de esportes, pertencentes a oficiais Ingleses (Steele, 1975).

Fernández e Gil (1975), citam que há evidências que havia raiva na América no período pré-Colombiano, a julgar por testemunhos de cronistas da conquista da 
América. Estes autores citam um testemunho deixado por Fernando de Oviedo em 1514: em "la Crónica de la Conquista de Darien, los indios enseñaron a los españoles el método de cauterizar las heridas producidas por las mordeduras de quirópteros". A raiva canina nas Américas teria se originado da Europa, pois as epizootias conhecidas começaram em cidades costeiras, aparentemente durante o século XVIII.

Conforme avaliam Smith e Seidel (1993), a dispersão das populações humanas através dos continentes, as colonizações, o mercado internacional e as guerras, influenciaram a dispersão das populações caninas ao redor do mundo, e também da raiva. Estes autores discutem aspectos históricos relacionados à disseminação do vírus rábico através dos continentes. A partir de estudos de seqüenciamento do genoma viral, verificou-se que amostras de vírus rábico isoladas em países do Norte da África estão mais relacionadas entre si do que com amostras isoladas no México. Tal comportamento se repete entre amostras de outros continentes e entre amostras de diferentes espécies. Os autores sugerem que a emergência de diferentes cepas do vírus rábico em cães pode ser resultado do efeito cumulativo do isolamento geográfico das populą̧̃̃es de canídeos, modulada posteriormente pelas influências politicas e culturais nas viagens de humanos e animais domésticos. Os períodos de livre mercado e transporte internacional de cães, intercalados por períodos de isolamento político, podem ter produzido bolsões de diversidade genética.

\section{Relatos pitorescos sobre a história da raiva}

Finalizando os relatos históricos, transcreve-se a seguir trechos do trabalho de Rocha (1955), que relata os antigos tratamentos preconizados para a raiva, ilustrando assim o quão trágico foi o caminho evolutivo do conhecimento da doença:

"Métodos de tratamento os mais variados foram seguidos pelos estudiosos da centúria passada, ingênuos uns, extranhos outros, todos porém, com a característica comum da inocuidade"... 
"De Bourrel é a sugestão curiosa de se dar aos dentes dos cães uma forma tal, que mais os aproximasse dos dentes dos herbívoros, não podendo, portanto, haver, com as mordeduras, a inoculação do vírus."

"Caffé aceitou a sugestão de Bourrel, aconselhando como mais conveniente a secção parcial dos dentes caninos e incisivos, deixando-se intatos ùnicamente os moláres."

"O grande remédio, porém, era a cauterização com o ferro em braza; ou então com o clorêto de antimônio, com o ácido nítrico, com o ácido sulfúrico, com o ácido fénico líquido a $10 \%$, com o amoníaco, com os alcális voláteis e com a potassa, entre outros".

"Como meio coadjuvante, fazia-se a suç̧ão das feridas, contanto que fossem perfeitos os dentes do sugador e isenta a bôca de soluções de continuidade"...

"Registre-se, igualmente, esta mistura de arruda, casca de rozeira brava, margarida, escorcioneira, alho e estrume de galinha,..."

"Repare-se como o banho sempre foi preconizado, desde a época de Celso, que assim o prescrevia: - 'Declarada a doença, mergulhar o doente em um vasto reservatório de água fria; caso o doente não saiba nadar irá ao fundo e o encarregado do tratamento o tirará logo depois, tendo o cuidado de repetir algumas vêzes o processo; mas, se o doente sabe nadar, o mesmo encarregado o obrigará a mergulhar algumas vêzes. Assim saciará a sêde e perderá o horror da água; depois dessas imersões forçadas será colocado em um banho de óleo quente para equilibrar as fôrças perdidas'..."

E concluindo:

"Faria Neves Sobrinho registra o fato em seu conto "O Hidrófobo", Recife - 1896, quando põe na bôca de um dos seus personagens esta frase aterradora:

'...e diziam que os médicos davam veneno para matar mais depressa; era até uma obra de caridade'..." 


\subsubsection{Aspectos históricos da raiva em Pernambuco}

Rocha (1955) menciona que a raiva era, aparentemente, desconhecida do índio Brasileiro. "Os Estudiosos das doenças e dos remédios do aborígine dela não fazem menção. $O$ cão doméstico, principal transmissor da doença, não era conhecido, tendo sido trazido ao Brasil pelos portugueses, com os primeiros núcleos de colonização."

\footnotetext{
Rocha (1955) ainda cita:

Fernão Cardim, em seu 'Tratados da terra e gente do Brasil, S. Paulo 1939, informa: - "Cães - Os cães têm multiplicado nesta terra, e há-os de muitas castas; são cá estimados assim entre os portuguêses que o trouxeram, como entre os indios que o estimam mais que quantas cousas têm, pelo os ajudarem na caça e serem animais domésticos, e assim os trazem as mulheres às costas de uma parte para a outra, e os criam como filhos, e lhes dão de mamar ao peito".
}

No Brasil, possivelmente existem registros históricos sobre a ocorrência da raiva em diferentes épocas, a julgar pelo grande número de teses sobre raiva realizadas no século 19, citadas por Rocha (1955). Infelizmente, trata-se de literatura dispersa, até o momento não compilada. Entretanto, em seu trabalho sobre a evolução da profilaxia da raiva em Pernambuco, o citado autor deixou registradas importantes informações históricas sobre a raiva no Brasil, particularmente em Pernambuco.

Pernambuco teve a segunda unidade do Instituto Pasteur no Brasil, ainda no período imperial, vindo a funcionar em 1899 sob a direção do Dr. Rodolfo Galvão. A primeira unidade do Instituto Pasteur foi inaugurada no Rio de Janeiro em 1888, e a terceira unidade foi inaugurada em São Paulo em 1904 (Rocha, 1955). Na atualidade, Pernambuco não conta mais com uma unidade do citado instituto.

A presença do cão é antiga na cidade de Recife. Em ilustrações de um livro de Souto Maior e Silva (1992), verifica-se que na paisagem recifense o cão está incluído em vistas retratadas por W. Bassler (1847), Emil Bauch (1852), Luís Schlappriz e Francisco Henrique Carls (1865). E possivelmente em muitas outras obras. Entretanto, parecem ser escassos na literatura os registros históricos sobre a raiva em Pernambuco. 
Rocha (1955) apresenta um resumo da distribuição de casos de raiva em Pernambuco, notificados no Instituto Pasteur entre os anos de 1899 e 1914 . Dentre 2257 casos notificados, $83 \%$ ocorreram na espécie canina, seguidos por casos em "gatos, cavalos, macacos, burros, bois, cobral ( $\underline{\text { sic), }}$, porco e papa-mel" ", da maneira citada pelo autor, nesta ordem. Os casos na cidade de Recife corresponderam a $72 \%$ dos 1355 casos notificados em municípios da região litorânea, sendo mais freqüentes os casos nos bairros de Boa Vista, Graças e Afogados, seguidos por Várzea, Poço da Panela, São José, Santo Antônio e Recife, nesta ordem.

Um trabalho de Cavalcanti e Silva (1974), reproduz os resultados de exames laboratoriais em 1987 amostras de cérebro de animais suspeitos de raiva, provenientes dos estados do Nordeste e remetidos ao Laboratório de Diagnóstico da Inspetoria de Defesa Animal (Laboratórios da Defesa Sanitária Animal do Ministério da Agricultura, à época localizado em Recife), durante o período compreendido entre maio de 1965 e dezembro de 1972, das quais 924 amostras foram positivas (46,5\%).

Cavalcanti e Silva (1974) citam que estima-se existirem "10 cães para cada 100 habitantes nos grandes centros." "Sabendo-se que a raiva é perpetuada nestes mesmos centros, pelas brigas dos cães entre si e destacando-se como elemento de maior periculosidade na disseminação da zoonose, o cão vadio, justifica-se perfeitamente a maior freqüência da doença nessa espécie." Os resultados dos exames são apresentados na Tabela 1.

\footnotetext{
10 grifo é nosso. Não se conhece a ocorrência de vírus rábico em répteis. $O$ termo foi citado conforme está na publicação original, sendo provável que tenha ocorrido erro tipográfico, possivelmente relacionado à palavra original cabra (Capra hircus).
}

\footnotetext{
${ }^{2} \mathrm{O}$ autor não cita nome científico correspondente ao nome vulgar "papa mel", bem como das espécies de primatas. Em Pernambuco, há na atualidade um animal conhecido como "papa mel", ameaçado de extinção: Eira barbara, Família Mustelidae, Ordem Carnivora. É uma espécie encontrada na América do Sul e América Central. Outros nomes pelos quais é conhecida no Brasil e em outros países são Irara, Taira e Tayra. É provável que seja a espécie citada pelo autor.
} 
Tabela 1: Casos positivos de raiva no Nordeste Brasileiro entre 1965 e 1972.

\begin{tabular}{lcccccccc}
\hline Anos & 1965 & 1966 & 1967 & 1968 & 1969 & 1970 & 1971 & 1972 \\
\hline Espécie & & & & & & & & \\
Bovina & 14 & 20 & 45 & 55 & 55 & 58 & 22 & 19 \\
Canina & 1 & 21 & 46 & 77 & 80 & 56 & 41 & 182 \\
Outras & 1 & 3 & 5 & 19 & 17 & 10 & 5 & 25 \\
\hline
\end{tabular}

- Felis cattus, Equus caballus, Equus asininus, Simia, Chiroptera, Capra hircus, Cavia porcelus ${ }^{3}$, Suis domesticus, Rattus rattus ${ }^{3}$ e Ovis aries.

Somente a partir da implantação do Programa Nacional de Profilaxia da Raiva no Brasil é que tomam-se disponiveis registros sistemáticos e mais confiáveis da raiva em Pernambuco.

3 Os autores não mencionam se são casos experimentais ou possivel infecção natural. Vale citar que Delpietro et al.(1990) relataram a transmissão experimental de raiva para roedores (Calomys musculimus e Mus musculus) que se alimentaram com tecidos animais naturalmente infectados pelo vírus rábico. A partir dos resultados do experimento, os autores mencionam o risco de roedores transmitirem raiva para o homem, e também a possibilidade de passagem do vírus para carnivoros predadores de roedores. Mas no Brasil, Estado de São Paulo, Summa et al. (1987) examinaram 1083 amostras de roedores e nenhuma delas foi positiva. Adicionalmente, o exame de dezenas de milhares de roedores silvestres e sinantrópicos nas Américas revelou raros casos de infeç̧ão rábica, sendo improvável que esses animais atuem como reservatórios do vírus rábico na natureza (WHO, 1992). 


\subsubsection{A doença}

Os vírus causadores das encefalites rábicas pertencem ao gênero Lyssavirus da família Rhabdoviridae. De acordo com aspectos sorológicos e antigênicos eles foram classificados em quatro sorotipos: os sorotipos causadores da raiva clássica e cepas vacinais (caracterizados como sorotipo 1), e os vírus relacionados denominados "Lagos bat", "Mokola" e "Duvenhage", compreendidos dentre os sorotipos 2, 3 e 4, para os quais as cepas vacinais do sorotipo 1 têm pouco ou nenhum efeito protetor. Os quatro sorotipos correspondem a quatro genótipos (1 a 4), aos quais foram adicionados os genótipos 5 e 6, correspondentes a Lyssavirus de morcegos europeus denominados EBL1 e EBL2 (Tordo, 1996). Recentemente, um vírus isolado de morcego frugívoro australiano foi classificado como Lyssavirus genótipo 7 (Gould et al., 1998).

$\mathrm{O}$ vírus rábico é um RNA vírus que tem forma de bala, com diâmetro de 75 $\mathrm{nm}$ e comprimento entre 100-300 nm. É formado por duas unidades estruturais principais, sendo uma unidade central cilíndrica constituída pelo ribonucleocapsídeo helicoidal, e um envelope protetor com $8 \mathrm{~nm}$ de espessura, coberto com projeções em forma de espículas (Tordo, 1996).

Cinco proteínas fazem parte da composição do vírus: (1) A proteína $L$, que é uma RNA polimerase dependente do RNA; (2) a glicoproteína $G$, ancorada na membrana e principal componente das espículas; (3) a nucleoproteína $N$; (4) a fosfoproteína $\mathrm{M} 1$, pertencente ao ribonucleocapsídeo; e (5) a proteína matriz ou de membrana, denominada M2, em contato com a membrana mas acoplada ao ribonucleocapsídeo (Tordo, 1996).

$\mathrm{Na}$ natureza, a raiva se mantém devido à existência de animais que atuam como reservatórios e vetores ${ }^{4}(\mathrm{sic})$. Os vetores devem ser animais altamente

4 Em todo o parágrafo, o autor utiliza as palavras "vector" e "vectors" (inglês), cuja tradução para o português é "vetor, portador de germes" (Veiga, 1979). No parágrafo foram mantidos os termos utilizados originalmente pelo autor, pois embora pareça mais apropriado 0 uso das palavras transmissor / transmissores em substituição a vetor no parágrafo em questão, na acepção da palavra não consideramos incorreto $o$ uso do termo vetor.

Em continuação, são apresentadas diversas definições relacionadas, encontradas em diferentes textos. São citadas por ajudarem uma melhor avaliação da terminologia utilizada. $\Rightarrow$ 
suscetíveis e capazes de desenvolver interações que favoreçam a transmissão da doença antes da morte. $\mathrm{Na}$ atualidade, a raposa vermelha é o principal vetor da raiva na Europa. Na América do Norte o guaxinim e o texugo também são importantes. O cão é o principal vetor nos paises subdesenvolvidos, apesar do envolvimento de animais silvestres, e espécies de morcegos atuam como os principais reservatórios de Lyssavirus pertencentes aos genótipos $2,4,5$ e 6 , além de atuar na transmissão do genótipo 1 (Tordo, 1996).

A principal forma de transmissão da raiva é através de feridas provocadas por mordidas. Também há registros de transmissão através de aerossóis e lambidas em pele ou mucosa com solução de continuidade (Tordo, 1996). O vírus rábico pode ser transmitido para receptores de transplante de córnea, embora existam poucos casos documentados (Javadi et al., 1996). Sipahioglu e Alpaut (1985) descrevem um caso por eles considerado o primeiro relato de transmissão placentária em humanos.

The American Heritage Dictionary (1994): "Vector": "2. Pathology. An organism, such as a mosquito or tick, that carries disease-causing microorganisms from one host to another".

Garnier e Delamare (1984): Vetor: "adj. ou s.m. (vector, de vehere, portar) (parasitologia). 'Hospedeiro intermediário que transmite uma infecção após evolução, em seu organismo, do germe que a produz' (Edm. Sergent, L. Parrot e A. Cataneil)."

Acha e Szyfres (1986) "Huésped - Es una persona o animal vivo, inclusive las aves y los artrópodos, que en. circunstancias naturales frente a las experimentales permiten la subsistencia o el alojamiento de un agente infeccioso. ... El huésped que sirve de vehículo es un vector en. el que el organismo permanece vivo pero no se desarrolla". Entretanto, ao definir a transmissão de agentes infecciosos, menciona dois tipos de transmissão por vetor (mecânica e biológica), "En Ambos casos se considera al artrópodo como vector".

Forattini (1992) assim define Hospedeiro: "Organismo que propicia alimento ou abrigo a organismo de outra espécie. Cf. interação positiva; interação negativa"; Reservatório: "Denominação particular, empregada em epidemiologia, para designar a fonte do agente infeccioso, quando representada por ser animado, animal ou vegetal. Cf. fonte"; Transmissão: "Denominação geral dada ao processo pelo qual o parasito encontra o hospedeiro. Em epidemiologia designa a transferência de um agente infeccioso, da fonte ao suscetivel". E vetor: "Denominação geral dada a espécie cujos organismos podem albergar o parasito e assim propiciar-lhe a transmissão para acesso ao hospedeiro. Cf. vetor biológico; vetor mecânico".

Thrusfield (1991) apresenta as seguintes definições: "Host: a plant, animal or arthropod that is capable of being infected with, and therefore giving sustenance to, an infectious agent. Replication or development of the agent usually occurs in the host". "Reservoir: a term commonly used as a synonym for, or prefix to, host, for instance 'reservoir', 'reservoir host'. A reservoir host is one in which an infectious agent normally lives and multiplies, and therefore is a common source of infection to other animals." "Vector: an animate transmitter of infectious agents. By common usage, vectors are defined as invertebrate animals - usually arthropods - that transmit infectious agents to vertebrates. The dictionary definition of the term inplies independent movement, that is, a living vehicle". "Biological vector: a vector (usually an arthropod) in which an infectious agent undergoes either a necessary part of its life-cycle, or multiplication, before transmition to the natural or secondary host.". 
Muller-Holve et al.(1977) entretanto, consideram altamente improvável esta forma de transmissão em humanos.

Após a mordida, o vírus rábico penetra em fibras nervosas desmielinizadas ou junções mioneurais. Em seguida, atinge o próximo neurônio sensorial ou motor nos gânglios dorsais ou corno anterior da medula espinhal, por transporte axonal retrógrado, onde se replica. Após a replicação, o vírus pode retornar para o sítio da mordida por transporte axonal, ou seguir ao longo da medula até o cérebro, onde infecta neurônios em quase todas as regiões cerebrais. Nos casos de infecção por aerossóis, o vírus entra no corpo através do epitélio olfatório do nariz, e é transportado para os neurônios do bulbo olfatório, onde se replica. Do cérebro, o vírus é transportado para a periferia através das vias neuronais, podendo ser encontrado nas glândulas salivares e tecidos de outros órgãos (Fu, 1997).

A ligação do vírus às células é mediada pela proteína $G$. $O$ processo de síntese de proteínas virais é precedido por uma transcrição autônoma mediada pela RNA polimerase RNA-dependente, resultando na produção de um RNA mensageiro complementar (Tordo, 1996).

As principais proteínas do vírus rábico envolvidas na resposta imunitária são a proteína $\mathrm{G}$, o ribonucleocapsídeo e a proteína $\mathrm{N}$, apesar de todas elas serem antigênicas. A proteína $\mathrm{G}$ é o único antígeno rábico que induz a produção de anticorpos vírus-neutralizantes de forma consistente, sugerindo ser este o antígeno mais importante para a imunização. A proteína $G$, e também as proteínas $\mathrm{N}$ e $\mathrm{M} 1$, induzem resposta imune citomediada envolvendo células $T$ auxiliares e células $T$ citotóxicas. Uma característica importante da proteína $\mathrm{N}$ é a sua menor variabilidade em relação aos outros antigenos rábicos, podendo assim proporcionar um aumento no espectro de proteção das vacinas anti-rábicas (Tordo, 1996).

$\mathrm{O}$ vírus rábico pode permanecer por um longo tempo no local da inoculação após a mordida. Durante o transporte centrípeto do vírus até o cérebro, anticorpos específicos não são detectados antes do surgimento dos sintomas da doença, talvez devido à insuficiente quantidade de antígeno viral para desencadear a resposta imune. Cães inoculados experimentalmente com cepas representativas do vírus rábico podem se recuperar da raiva clínica, independente da cepa ou tamanho do inóculo administrado (Fekadu, 1988). 
$\mathrm{Na}$ raiva experimental, o período de incubação e de morbidade dependem mais da dose de vírus inoculado do que da cepa utilizada, e variou entre 9 e 42 dias com uma cepa da Etiópia, e entre 12 e 69 dias com uma cepa Mexicana (Fekadu; Shaddock, 1984). No citado estudo experimental, $70 \%$ dos cães desenvolveram raiva paralítica, $12 \%$ desenvolveram a forma furiosa e $18 \%$ morreram sem apresentar qualquer sintoma.

Cinco casos naturais de "raiva muda" são descritos por Okolo (1986), que aponta para os riscos associados a esses casos de raiva que não são prontamente diagnosticados como tal, devido a motivos como se associar raiva a comportamento agressivo do animal, verificado na forma furiosa. Apenas um dos cães doentes era vacinado. Embora se utilize a expressão "raiva muda" no trabalho, os casos descritos apresentavam sintomatologia neurológica verificada em casos de raiva paralítica.

Cães inoculados com cepas de cães e cepas de morcegos da América do Norte, e com cepas de cães Africanos, adoeceram e se recuperaram em $20 \%$ dos casos (Fekadu, 1988). Sete cães inoculados com uma cepa de vírus rábico da Etiópia, e um cão inoculado com uma cepa Mexicana, não desenvolveram doença nem apresentaram anticorpos detectáveis durante um período de dois anos de observação (Fekadu; Shaddock, 1984). Entretanto, Fekadu et al.(1981) relatam a excreção intermitente de vírus rábico na saliva de um cão, inoculado com uma cepa isolada de um cão etíope aparentemente são, sugerindo a existência do estado de portador de raiva.

A presença do vírus rábico na saliva e glândulas salivares é o fator mais importante na transmissão da raiva. Há casos documentados de animais inoculados com vírus rábico que eliminam o agente até 14 dias antes do surgimento dos sintomas. Também já se verificou excreção intermitente do vírus rábico na saliva por até 305 dias após a recuperação da doença, em cães inoculados com cepa de rua de vírus rábico da Etiópia (Fekadu, 1988).

Em estudo experimental de Fekadu e Sahddock (1984), o vírus foi detectado nas glândulas salivares de $52,9 \%$ dos animais inoculados com uma cepa da Etiópia, dependendo esta presença da dose inoculada. Em animais inoculados com uma cepa Mexicana, o vírus foi detectado na glândula salivar de 72,7 \% dos cães, e a presença não foi afetada pelo inóculo. 
Chamelet (1986) estudou a presença de vírus rábico na saliva e glândulas salivares de 50 cães naturalmente infectados, atendidos no Instituto Pasteur de São Paulo; $74 \%$ dos animais apresentaram infectividade simultânea na saliva e glândulas salivares. As glândulas submaxilares foram positivas em $98 \%$ dos casos, a saliva em $88 \%$, e as glândulas parótidas em $80 \%$. Inicialmente mais elevados, os títulos verificados 12 horas antes da morte do animal eram muito baixos. Em $10 \%$ dos casos a saliva foi negativa, e em $2 \%$ dos casos todas as amostras examinadas foram negativas. Dentre os animais raivosos, existiam 4 animais com história de vacinação prévia.

Experimentalmente, verificou-se que $25 \%$ a $40 \%$ de animais inoculados com elevadas doses de vírus rábico apresentavam o vírus nas glândulas salivares, enquanto que o vírus foi detectado nas glândulas salivares de quase todos os animais inoculados com pequenas doses. A inoculação de pequenas doses de vírus tende a produzir maiores periodos de incubação e resultar em maiores alterações patológicas (Fekadu, 1988).

Apesar da marcante sintomatologia apresentada, os animais que morrem de raiva apresentam pouca ou nenhuma alteração macroscópica no Sistema Nervoso Central (SNC). Pode ocorrer congestão meníngea, e o edema cerebral é raro. Microscopicamente pode haver infiltrado celular no SNC e destruição celular. Inclusões de Negri, de natureza eosinofilica e específicas para a raiva, são encontradas no citoplasma neuronal. Estas são constituídas em sua maioria por nucleoproteínas. Geralmente o número de corpúsculos de Negri encontrados é inversamente proporcional à severidade da inflamação (Fekadu, 1988).

Estudos neurofarmacológicos sugerem que a raiva fatal é resultante mais de alterações funcionais dos neurônios do que de danos estruturais. $O$ virus induz a expressão de genes que resultam na redução de neuropeptídeos e neurotransmissores essenciais à função neuronal, levando a distúrbios funcionais no $\mathrm{SNC}$, e eventualmente à morte dos indivíduos infectados (Fu, 1997).

Ito et al. (1985) realizaram estudo comparativo para detecção do vírus rábico em diferentes áreas do cérebro e medula, de animais infectados naturalmente ou experimentalmente, utilizando as técnicas de imunofluorescência e inoculação em camundongos. Em cães infectados naturalmente, os resultados foram todos positivos 
em ambas as provas para: corno de Amon, cerebelo e bulbo; nas medulas cervical, torácica, lombar e sacral, estes valores variaram entre 93,5 e $100 \%$. Os resultados apresentaram $100 \%$ de positividade em todos os 6 animais inoculados experimentalmente que morreram de raiva. Os autores ressaltam a importância da acurácia e presteza no diagnóstico da raiva para os serviços de saúde pública, particularmente para a orientação de atividades de controle de foco, na redução da possibilidade de raiva humana e também para evitar imunização desnecessária. 


\subsubsection{Populações caninas, ecologia, epidemiologia e o controle da raiva}

Existem evidências de que o cão foi domesticado há aproximadamente 12.000 anos. Em Israel, o esqueleto de um filhote de lobo ou cão foi encontrado enterrado junto a um esqueleto humano, em uma associação que indica relacionamento estreito entre o homem e o cão (Davis e Valla, 1978).

Os cães são encontrados em praticamente cada continente ou ilha ocupados pelo homem, ocorrendo em elevadas densidades populacionais como nenhuma outra espécie de carnivoro. Há registros de povoados onde o número de cães é superior ao número de pessoas. Estima-se que a população canina mundial pode chegar a 500 milhões de animais (Wandeler et al., 1993).

Wandeler et al. (1993) citam que a abundância da população canina é dependente do hábitat, particularmente da disponibilidade de alimentos, água e abrigo. Estes aspectos são influenciados pelos padrões de colonização, distribuição de lixo e de resíduos, regras para criação de animais e outras práticas culturais. Cada cão pode ter diferentes status de propriedade, diferentes graus de restrição ao seu movimento, interação social e reprodução, e diferentes níveis de dependência do cuidado humano.

Os cães são mantidos pelo homem devido aos mais diversos motivos, como a habilidade que têm para caçar, guardar as pessoas e a propriedade, como animais de tração, como objeto de troca, como fonte alimentar, ou simplesmente pelo papel que desempenham como parceiros sociais e companheiros (Wandeler et al., 1993). Os citados autores apresentam uma detalhada revisão sobre diversos aspectos relacionados às populações caninas.

A distribuição e abundância de cães variam de lugar para lugar. Um relatório da Organização Mundial de Saúde (WHO, 1988) descreve o resultado de estudos realizados no Equador, Tunísia e Sri Lanka. Em áreas urbanas e rurais estudadas, entre $60 \%$ e $87 \%$ dos domicílios possuíam cães, e o número de pessoas por cada cão variou entre 5,8:1 e 11:1. A densidade canina variou entre 15 e 2400 cães por $\mathrm{km} 2$.

Em Lima e Callao, no Peru, estimou-se uma razão de 1 cão para cada 10 habitantes, e de 1 gato para 18 habitantes; $58 \%$ dos cães eram do sexo masculino e $42 \%$ do sexo feminino (Chomel et al., 1988). 
Na Tunísia, Osman e Nadia (1988) estimaram a existência de 10,9 cães por 100 habitantes ( 1 cão para 9,17 habitantes).

As populações caninas de diferentes lugares também apresentam diferentes estruturas etárias, diferentes razões entre sexos, variáveis frequências de raças e origens dos cães. As taxas de reprodução e mortalidade são características de cada lugar. Na Tunísia por exemplo, a mortalidade, reprodução, migração e emigração são tais que asseguram uma população canina estacionária. Lá, a maior parte dos cães recém-nascidos são mortos pelos proprietários, outra parte morre de doenças ou desnutrição, e apenas uma pequena parte dos animais sobrevive. A renovação populacional pode chegar a $35 \%$ dentro de um ano. Já no Equador, parece não haver controle do tamanho das ninhadas por parte dos proprietários. De uma maneira geral, cães do sexo masculino apresentam ligeira predominância sobre cães do sexo feminino (WHO, 1988).

Em áreas do Equador, Tunísia e Sri Lanka (WHO, 1988), a maior parte dos cães foi recebida como presente de parentes ou vizinhos, sendo os demais animais adquiridos por compra, cria nascida no próprio domicílio ou adotados das ruas. Em Sri Lanka, a média de idade dos animais foi estimada entre 3 e 4 anos, enquanto que na Tunisia e no Equador esta média era de apenas 2,5 anos. Os niveis de restrição, supervisão, e a utilização dos cães também são variáveis de acordo com a localidade, e podem ser dependentes do status socioeconômico dos domicílios. Nas localidades citadas, os cães são mantidos em sua maioria como animais de guarda ou estimação, ou também como pastores no caso da Tunísia.

$\mathrm{Na}$ Nigéria, verificou-se que a população canina domiciliada em áreas urbanas é duas vezes maior do que em áreas rurais. Foram encontradas razões entre cães e pessoas iguais a 1:21 e 1:45, para áreas urbanas e rurais, respectivamente. Para essas áreas, as densidades foram iguais a $131 / \mathrm{km}^{2}$ e $15 / \mathrm{km}^{2}$, nesta ordem. Entre $18,2 \%$ e $29,6 \%$ dos domicílios possuíam cães. Não existiu diferença entre as proporções de animais quanto ao sexo, e $46 \%$ dos cães tinham menos de um ano de idade. A maioria dos cães são de raça nativa, com função de guarda ou caça, e $96 \%$ deles nunca foi mantido confinado. Apesar de receberem alimento dos donos quando presos, os animais, quando não restritos, buscam alimentação no lixo e perambulam pelas ruas em busca de acasalamento. O quadro descrito traz evidentes implicações 
para a saúde pública, relacionadas à transmissão de doenças (Oboegbulem e Nwakonobi, 1989).

Durante uma campanha de vacinação anti-rábica no Senegal em 1987, foram estudados aspectos relacionados à população canina em uma zona suburbana de Dakar. Os cães são mantidos sobretudo devido à insegurança existente, e fatores étnicos influenciam a abundância desses animais. Grande parte dos cães pertencem a jovens e adolescentes, e a maioria dos animais são jovens (idade média de 29 meses), havendo preferência por indivíduos do sexo masculino. Segundo Akakpo et al.(1990), a pobreza favorece à não vacinação e não restrição dos cães, que perambulam em busca de alimentos para sobreviver, facilitando assim o contato permanente entre animais e a transmissão de doenças.

No Zimbabwe estimou-se uma razão média de 1 cão para cada 6,5 habitantes. Os cães apresentavam idade média de 2,3 anos e em sua maioria (70\%) eram utilizados com finalidade de guarda (Brooks, 1990). Diversas outras características da população canina do local são descritas.

Estudos realizados em países desenvolvidos também fornecem importantes informações sobre a criação de cães, possibilitando a observação de contrastes. Na Califórnia, década de 70, a criação de animais de estimação, em sua maioria cães e gatos, parecia estar mais relacionada a fatores econômicos. Pessoas que criavam cães tendiam a ter renda maior do que aquelas que não criavam cães, e a presença de crianças no domicílio aumentava a chance de existência de animais de estimação (Franti et al., 1974).

Em Manhatan (Nassar; Mosier, 1980), estimou-se uma razão entre pessoas e cães de 4,14:1; $76 \%$ das cadelas eram ovariectomizadas, numa população de tamanho estável. Devido ao pequeno número de nascimentos, a estabilidade era mantida pela imigração de cães jovens, em sua maioria adquiridos de criadores de outras cidades.

Diversos outros aspectos ligados à dinâmica populacional canina, a criação de animais em centros urbanos e a transmissão de doenças para o homem são discutidos por Beran et al. (1972), Beck (1973), Feldmann (1974), Frant et al.(1974), Beck (1975), Nassar e Mosier (1980), WHO (1987), Beran e Frith (1988), Coman e Robinson (1989), Cook (1989), Carter (1990), e WHO (1990). 
Em condições ótimas, uma população canina poderia quase triplicar a cada ano, mas na realidade, o tamanho desta chega a uma situação de equilíbrio ao atingir a capacidade de suporte do meio ambiente, a qual depende da disponibilidade e qualidade de recursos. Diferentemente das populações silvestres, as populações caninas recebem recursos oriundos das populações humanas, e a capacidade de suporte do meio estará relacionada a diferentes hábitats, culturas, e camadas sociais das populações humanas urbanas ou rurais. Qualquer redução na população canina devido ao aumento na mortalidade é rapidamente compensado pelo aumento na reprodução e taxa de sobrevivência. A expectativa de vida dos sobreviventes aumentará devido a esta fração remanescente ter melhor acesso aos recursos disponiveis (Wandeler et al., 1988).

Cães bem supervisionados, apresentam taxa reprodutiva relativamente baixa, porque alguns deles são castrados e as fêmeas em cio são mantidas sob controle. A média de idade nesses seguimentos é relativamente alta, aproximadamente 4,5 anos em cães dos Estados Unidos (Wandeler et al., 1988) em contraste com a baixa média de 2,5 anos de idade observada em estudos realizados em países subdesenvolvidos (WHO, 1988).

Cães com proprietário mas pobremente supervisionados, reproduzem livremente, e a taxa de sucesso de criação desses animais é elevada, pois eles recebem abrigo e proteção dos seus donos. As crias excedentes de cães pobremente supervisionados originam as populações de cães sem dono, os quais são tolerados, embora sejam alimentados irregularmente. Estes cães se abrigam em estruturas desocupadas e apresentam baixa taxa de sucesso reprodutivo, em parte devido à falta de proteção para as crias (Wandeler et al., 1988).

Fu (1997) comenta que o mundo vive hoje uma situação de raiva epidêmica, e excetuando alguns países insulares, como Austrália ${ }^{5}$, Nova Zelândia, Inglaterra ${ }^{6} \mathrm{e}$

5 Fraser et al.(1996) comunicaram a caracterização de um vírus do gênero Lyssavirus, Família Rhabdoviridae, em Pteropus alecto, morcego frugivoro nativo da Austrália. Mais tarde, os Lyssavirus isolados de Pteropus, intimamente relacionados ao sorotipo 1 do vírus rábico clássico, foram classificados como Lyssavirus genótipo 7, um membro do gênero Lyssavirus até então não reconhecido (Gould et al., 1998).

6 Durante um período de 10 anos (1986-1995), 23 espécies de morcegos do reino unido foram pesquisadas para a presença de antígeno rábico, sendo negativos todos os 1882 animais testados. Em 
Japão, a raiva continua ocorrendo em quase todos os países do mundo, e em muitos deles o número de casos da doença está aumentando. A razão mais importante para a raiva permanecer endêmica são os reservatórios globais da doença. Os cães continuam sendo os principais reservatórios na África, Ásia e América Latina, onde ocorrem a maioria dos casos de raiva humana. Nos países onde a raiva canina foi controlada através de vacinação, a exemplo de países na Europa e América do Norte, o problema persiste em animais silvestres como raposas e guaxinins. A raiva também é endêmica em morcegos hematófagos do México à Argentina, e em morcegos insetívoros na América do Norte e Europa.

Segundo Wandeler et al. (1988), as populações caninas, assim como outras populações, dependem de recursos como alimento, água e abrigo, os quais são fornecidos pelo homem, deliberadamente ou não. Já as práticas de restrição e cuidados com os cães são influenciadas por fatores culturais. Os cães são os principais reservatórios da raiva devido ao fato de sempre atingirem densidades que possibilitam a manutenção da doença. No passado, os programas de controle da raiva obtiveram sucesso, mas a maioria deles estão falhando na atualidade, sendo a ocorrência da doença predominante nos países subdesenvolvidos. A maioria dos casos de raiva humana são transmitidos pelo cão, e ocorrem em países subdesenvolvidos, sob circunstâncias culturais e ecológicas muito diferentes daquelas existentes nos países ocidentais industrializados. Assim, para este autor, os programas de controle da raiva devem levar em consideração princípios de gerenciamento, mas também aspectos da biologia das populações caninas e características culturais das comunidades.

$\mathrm{Na}$ maioria dos países subdesenvolvidos, a raiva canina é um grande problema em centros urbanos e subúrbios das megalópoles. Por volta do ano 2000, em torno de $75 \%$ das cidades com 5 milhões ou mais de habitantes estarão localizadas em países menos desenvolvidos (Chomel, 1993). Nestes países, a raiva está se disseminando em novas áreas, e a freqüência de casos está aumentando nas áreas onde a doença já é prevalente. Isto se deve principalmente ao aumento $\mathrm{e}$ 
mobilidade das populações humanas, com aumento concomitante das populações caninas. Essas mudanças ecológicas resultam no aumento da densidade ou proximidade das populaçð̃es caninas (WHO, 1982).

A este respeito Fernández e Gil (1975), na Venezuela, já citavam:

"La rabia canina, entre nosotros, há tenido un comportamiento extensivo, siguiendo los grandes flujos de desarollo económico y poblacionales, ocupando cada vez nuevos espacios, de ahí la necesidad de hacer estudios regionales y de emprender acciones regionales para su control".

A influência da urbanização em massa nos paises da América Latina sobre o comportamento da raiva é mencionada por Cifuentes (1988). À época do trabalho, estimava-se que $65 \%$ da população da América Latina vivia em áreas urbanas, e que ao final do século este valor chegaria a $75 \%$. Entretanto, devido a dificuldades de naturezas diversas, grande parte dessas populações vivem em áreas marginais - onde a superpopulação, desemprego e insegurança são prevalentes. Este quadro favorece o aumento das populaçð̃es de animais urbanos, particularmente de cães e gatos, e em conseqüência, o aumento do número de casos de zoonoses como a raiva.

Sabe-se que as elevadas densidades de cães favorecem a manutenção do vírus rábico em populações animais, mas não se sabe ao certo o limiar de densidade necessário à manutenção do agente em uma população animal.

Cleaveland e Dye (1995) demonstram evidências de manutenção da infecção por vírus rábico em um distrito com densidade canina $>5 / \mathrm{km}^{2}$, mas não em outros dois com densidades caninas de valor $<1 / \mathrm{km}^{2}$. Estes autores entretanto, ainda consideram este primeiro valor muito abaixo da densidade requerida para a persistência da doença, sugerindo uma possibilidade de que animais portadores, ainda que ocorrendo em freqüências muito baixas, favoreçam a persistência da infecção. Foggin (1988) apud Cleaveland e Dye (1995) apresentam evidências de que a raiva parece persistir em populações com densidade média de $6 \mathrm{cães} / \mathrm{km}^{2}$.

Beran e Frith (1988) citam que em Guayaquil, Equador, onde há uma densidade média de 1.792 cães $/ \mathrm{km}^{2}$ (de 681 a $2.388 / \mathrm{km}^{2}$ ), a raiva apresenta endemicidade em setores onde a população de cães não vacinados é maior do que 
$680 / \mathrm{km}^{2}$, enquanto que em setores com baixa densidade de cães não vacinados a raiva ocorre mais provavelmente na forma de surtos esporádicos ou epidêmicos.

Os contatos freqüentes entre cães, em especial durante as estações de acasalamento, são um dos fatores que favorecem a transmissão da raiva (Belcher et al., 1976; Ernst e Fabrega, 1989; Narayan, 1985). Entretanto, no Peru se observou uma estreita relação entre a ocorrência de casos de raiva e os nascimentos de cães (Málaga et al., 1979), sugerindo que a estacionalidade está associada à mudança na estrutura etária da população ao longo do ano.

A caracterização dos casos de raiva em diferentes localidades pode fornecer elementos para uma melhor compreensão de importantes aspectos epidemiológicos relacionados à raiva canina.

Belcher et al. (1976) citam que a grande maioria dos casos de raiva em Accra, Gana, ocorreram em cães de estimação, jovens, usualmente não vacinados. Foram descritos quatro casos de falha de vacinação, dois dos quais em animais vacinados 12 meses antes, e outros dois vacinados entre 15 e 18 meses antes, mas as possíveis causas não foram elucidadas.

De maneira diferente da maioria dos relatos, Kennedy (1988), cita que no Zimbabwe, apenas $23 \%$ dos casos confirmados de raiva canina ocorreram em cães com donos identificados, e $73 \%$ foram considerados animais errantes. Por outro lado, a grande maioria dos cães raivosos (92 \%) não apresentavam indicativos de vacinação. Aproximadamente $1 / 3$ dos casos de raiva em cães com dono ocorreram em animais com idade entre três e seis meses.

Bhatia (1988), em Delhi, Índia, observaram a grande maioria dos casos de raiva em animais com menos de 1 ano, ocorrendo um decréscimo gradual com o aumento da idade. Ocorreu predominância de casos em machos, mas não significativa. A maior freqüência foi registrada em animais não vacinados, e a ocorrência de raiva em vacinados é atribuída ao impróprio armazenamento das vacinas e dosagem inadequada. Também na Índia, Rajan et al. (1990) citam 75,6 $\%$ de casos de raiva canina em machos.

Em uma área central de Java, na Indonésia, entre 1995-1996, 89 \% dos casos de raiva durante uma epidemia ocorreram em cães. Setenta por cento dos cães tinham proprietário identificável (Waltner-Toews et al., 1990). Estes cães foram 
classificados pelos autores como cães domésticos, e os demais, por exclusão, cães errantes.

Em Lima, no Peru, Malaga et al. (1976) descrevem a ocorrência de $78 \%$ dos casos de raiva canina em machos e $22 \%$ em fêmeas, parte explicado pela existência de $71 \%$ de machos e $29 \%$ de fềmeas na população, e também porque os machos saem mais às ruas, estando expostos a maior risco. Quanto à idade, $39 \%$ dos casos ocorreram em animais com menos de 1 ano ( $28 \%$ da população), $34 \%$ em animais com 1 ano ( $21 \%$ da população), $13 \%$ naqueles com 2 anos (17\% população), $8 \%$ em cães com 3 anos (12\% população), $3 \%$ em cães com 4 anos ( $7 \%$ população), 2 $\%$ em cães com 5 anos ( $4 \%$ população) e $2 \%$ no grupo etário com mais de 5 anos (10\% população). Observou-se redução progressiva da freqüência de raiva com o aumento da idade, explicado pelo maior percentual de cães vacinados e revacinados nos grupos de maior idade. Cães com menos de 6 meses foram responsáveis por 56 $\%$ dos casos em animais com menos de 1 ano de idade.

Em Guayaquil, Equador, 7,6\% dos casos de raiva ocorreram em filhotes com menos de 3 meses. Lá, $85 \%$ dos cães com 1 a 4 anos e $95 \%$ dos cães com 5 ou mais anos já tinham sido vacinados contra raiva ao menos uma vez (Beran e Frith, 1988).

Segundo Burnes et al. (1991), em Tamaulipas, no México, 78,7 \% dos casos de raiva ocorreram em cães e $11,8 \%$ dos casos em gatos. Dentre os cães, $63,6 \%$ eram machos e 36,3 \% fềmeas, o que foi atribuído à maior agressividade e comportamento de domínio territorial característico do sexo masculino, ou ainda pela preferência que a população tem pelos machos. A idade média dos cães raivosos era de 15,6 meses. Apenas $22 \%$ dos positivos eram vacinados contra raiva, na maioria das vezes, segundo os autores, por "negligência" e desconhecimento das responsabilidades que os proprietários de cães devem ter.

Em Hermosillo, México, Eng et al. (1993) estimaram idade mediana dos cães raivosos em 1 ano; $8 \%$ tinham menos de 3 meses e $44 \%$ menos de 1 ano. Destes, $69 \%$ eram machos e $98 \%$ cães com dono. Segundo informaçðes dos proprietários, $30 \%$ dos cães raivosos foram vacinados contra raiva. A maior parte dos animais (89 \%) foi adquirida na própria cidade e $11 \%$ fora dela. Comparando dados da 
população canina e dos animais que morreram, observou-se que os cães com dono eram significativamente mais velhos do que os cães raivosos.

Nos Estados Unidos, a idade mediana de cães e gatos raivosos foi igual a 1 ano (Eng e Fishbein, 1990). Os cães raivosos tinham maior probabilidade de serem machos $(O R=2,6), 84 \%$ eram animais de estimação, e $10 \%$ eram cães errantes. A grande maioria dos cães não eram vacinados contra raiva. Ocorreram 3 casos de falha de vacinação em cães e gatos, todos eles em animais que receberam uma única dose de vacina inativada. A única vacina implicada em mais de uma vez foi uma vacina produzida em cérebro de camundongos lactentes. Todos os três animais foram vacinados por via intramuscular e por veterinários licenciados. Os lotes das vacinas que foram testados tinham elevada potência (NIH entre 3,8 e 4,2), e não se sabe como as vacinas foram manuseadas em campo. Em função dos achados, estes autores ressaltam a importância de aderir a programas de revacinação, pois a probabilidade de uma resposta imune adequada aumenta com vacinações subseqüentes.

Segundo Málaga et al.(1976), a maior freqüência de casos de raiva entre animais com menos de um ano de idade, a qual tende a diminuir com o aumento da idade, se explica pela maior proporção de animais vacinados e revacinados nos grupos de maior idade. A proporção de animais não vacinados diminui com a idade. Provavelmente, os cães que recebem maiores cuidados de seus donos são vacinados com maior freqüência, e também tendem a ter uma expectativa de vida maior.

No Chile, ocorreu o desaparecimento do padrão de sazonalidade da raiva, e o comportamento de ciclos, a cada cinco anos, tornou-se pouco evidente quando a freqüência da doença atingiu baixos níveis, após a implantação de medidas de controle da doença. Os ciclos eram atribuídos a mudanças na composição da população, aumentando o número de animais suscetíveis (Ernst e Fabrega, 1989; Ernst, 1989).

Chomel et al. (1987) descrevem a situação da raiva em Lima, no Peru, durante a década de 80. À época, a cidade possuía entre 5 e 6 milhões de habitantes, metade dos quais vivendo em áreas de baixo status socioeconômico, onde diversas doenças infecciosas eram endêmicas, inclusive a raiva. Durante anos, ocorreu a imigração de grande número de pessoas e cães, muitos destes oriundos de áreas onde 
a raiva era endêmica. Após o quase desaparecimento da raiva na década de 70 , em conseqüência de campanhas de vacinação em massa, realizadas entre 1971 e 1973, a raiva ressurgiu em 1980, e no ano de 1982 foram notificados mais de mil casos de raiva canina na cidade, e 13 casos humanos, o que motivou a realização de novos programas de imunização.

$\mathrm{Na}$ Tunísia, os programas de controle da raiva enfatizam o controle da raiva em cães, considerados os reservatórios essenciais de vírus para outros animais e humanos (Osman e Haddad, 1988). Lá, a raiva em cães corresponde a $90 \%$ de todos os casos de raiva animal. Os programas compreendem a vacinação sistemática dos cães acessiveis e o controle dos demais cães (cães errantes), tendo como meta a eliminação de $10 \%$ da população canina estimada. Neste, foram usados quatro vacinas produzidas em cultivo celular, e uma outra produzida em tecido nervoso de terneiro. Após o início de um programa de campo para o controle da raiva, constatou-se diminuição no número de casos de raiva animal e humana. Estes últimos foram mais comuns em áreas com elevada quantidade de cães errantes, onde os contatos entre homens e animais são mais freqüentes.

$\mathrm{Na}$ Tailândia (Wasi et al., 1997) estima-se que apenas $20 \%$ dos 10 milhões de cães são atingidos pela vacinação, apesar de $80 \%$ deles serem acessíveis à vacinação. Em torno de 300.000 cães errantes são eliminados a cada ano. A maioria dos casos de raiva humana se devem a mordidas por cães, e $50 \%$ dos cães testados, e 20-25\% dos gatos, são positivos para raiva.

Chomel et al. (1988) consideram que para controlar focos enzoóticos de raiva, campanhas de vacinação em massa devem ser realizadas regularmente, particularmente onde não existem programas de controle de cães errantes, já estabelecidos e mantidos.

$\mathrm{Na}$ Europa e na América ao norte do México, apenas $0,1 \%$ a $5 \%$ dos casos de raiva envolvem cães, o que se deve a três fatores: uma grande proporção dos cães têm movimentação restrita; a vacinação canina é fortemente recomendada ou é compulsória; e cepas de vírus de animais silvestres, que ocorrem nessas localidades, possivelmente não se propagam bem em populações caninas (Wandeler et al., 1988).

A melhor maneira de se reduzir a taxa de exposição dos humanos à raiva é controlar a doença em seu principal hospedeiro, o cão. Os métodos clássicos 
envolvem o controle da população canina e a vacinação, os quais apresentaram grande sucesso em diversos países nas décadas de 40 e 50 (Wandeler et al., 1981). De acordo com os citados autores, os recentes insucessos no controle da raiva ocorreram devido à falta de programas adequados que levassem em consideração a biologia da população canina, e devido a características culturais e estruturais. $O$ tamanho e acessibilidade da população canina alvo das medidas devem ser conhecidos. Embora a eliminação de cães errantes seja usualmente ineficaz como método de controle populacional, tal medida pode vir a criar conscientização pública e maior responsabilidade dos criadores. 


\subsubsection{Vacinas e Vacinação anti-rábica}

\section{Vacinas anti-rábicas}

Desde o desenvolvimento da primeira vacina anti-rábica por Pasteur, no final do século 19, até meados das décadas de 50 e 60 , predominou o uso de vacinas que usualmente eram produzidas em tecido nervoso. Eram vacinas com vírus modificado ou inativado. A primeira vacina anti-rábica com virus modificado usada em cães foi uma vacina produzida em embrião de pinto, desenvolvida por Koprowski e Cox em 1948. Esta vacina utilizava a cepa Flury, após 136 passagens intra-cerebrais em pintos de um dia (Sikes, 1975).

Johnson (1954) verificou que cães imunizados com vacina produzida em cérebro de ovino, com vírus inativados pelo fenol, apresentavam elevado grau de imunidade após 1 ano da vacinação, e comparando esta com a vacina Flury, a última se mostrou superior e também de mais longa duração. Após o desafio com vírus de rua, realizado 12 meses depois da vacinação, $11,5 \%$ de 52 cães vacinados desenvolveram raiva enquanto que $79 \%$ dos animais não vacinados morreram da doença.

Merry et al. (1969), considerando o fato de que a vacina Flury HEP produzia imunidade superior, quando comparada às vacinas inativadas com fenol, e a indicação de se utilizar vias diferentes para as vacinas com vírus vivo (intramuscular) em contraposição à via subcutânea utilizada para as vacinas inativadas, realizaram estudo para comparar a resposta de cães à vacina Flury HEP, aplicada pelas vias subcutânea e intramuscular. Não foram verificadas diferenças significativas entre as duas vias de inoculação.

Um outro achado de Merry et al. (1969) foi que alguns animais vacinados, mas com títulos baixos ou mesmo títulos não detectáveis, sobreviveram ao desafio.

Segundo Sikes et al. (1971), até o início da década de 60 nos Estados Unidos, existiam apenas 2 tipos de vacinas anti-rábicas comercialmente disponiveis para uso em animais domésticos. Uma delas, a vacina inativada produzida em tecido nervoso de pequenos ruminantes, e a outra, a vacina Flury, que era uma vacina com vírus modificado. 
Durante a década de 60 foram desenvolvidas diversas vacinas, dentre elas vacinas inativadas e vacinas modificadas produzidas em cultivo de tecidos, e a vacina inativada produzida em cérebro de camundongos lactentes (Sikes, 1975).

$\mathrm{Na}$ década de 70 , Sikes et al. (1971) testaram 8 tipos de vacina quanto à qualidade imunogênica e duração da imunidade, incluindo dentre estas uma vacina produzida em cérebro de camundongos lactentes (VCCL), tipo utilizado na América Latina já na época do experimento. A vacina purificada, concentrada para conter 10 vezes a massa antigênica da VCCL, foi a única que protegeu $100 \%$ dos cães durante três anos.

Nos experimentos de Sikes et al.(1971), após 36-39 meses da vacinação, 31\% de 59 animais que receberam vacinas inativadas - incluindo a VCCL, tinham anticorpos detectáveis, ao passo que $77 \%$ dos 147 animais que receberam vacinas atenuadas ainda tinham anticorpos detectáveis. A VCCL protegeu todos os cães por 12 meses, e $80 \%$ deles por 3 anos. A taxa de persistência de anticorpos foi significativamente maior em cães que receberam vacina purificada em comparação com a VCCL, mas não em comparação com as vacinas com vírus vivo. A VCCL, com potência testada pelo método do NIH, apresentou valor antigênico de 1,5 , que segundo os autores, era cinco vezes maior do que a potência mínima requerida para uso como vacina anti-rábica humana.

A VCCL apresentou grande eficácia em um estudo realizado por Fields et al. (1976). Vinte e quatro cães foram inoculados com uma única dose de $1 \mathrm{ml} \mathrm{da}$ VCCL, por via intramuscular e diluída para conter valor antigênico igual a 3,15 ?. Posteriormente os cães foram desafiados com vírus rábico de rua ${ }^{8}$. Todos os animais sobreviveram ao desafio aos 37 meses após a vacinação. Após o desafio, detectou-se aumento dos títulos de anticorpos, mesmo em animais que previamente não apresentavam níveis de anticorpos detectáveis. Este foi o caso de 2 animais que não mais apresentavam anticorpos detectáveis aos 36 meses, mas resistiram ao desafio. Durante o desafio, o virus atuaria como um 'booster' para os animais que foram vacinados no passado. Os autores conclúram que apesar da relação entre os títulos de anticorpos e proteção, os títulos de anticorpos podem declinar de um título

\footnotetext{
${ }^{7}$ Os autores não citam o método utilizado para estimar o valor antigênico.
} 
positivo elevado até um nível baixo ou negativo, mas o animal poderá permanecer resistente ao desafio.

No Brasil, em condições experimentais, verificou-se que cães confinados e bem nutridos respondem melhor à vacinação com VCCL do que cães mal nutridos e em más condições de saúde, ainda que estes últimos animais sejam revacinados. Observou-se que o título de anticorpos aumentou com o aumento do número de doses da vacina (Soares et al., 1992).

Por outro lado, também há evidências de que populações de cães errantes apresentam menor proporção de animais com títulos protetores contra raiva, em comparação com animais domiciliados (no texto, o termo domiciliado não implica em restrição total ou parcial, indica antes um domicílio de referência, e provavelmente maior atenção em relação ao cão).

Bota et al. (1987) estudaram dois grupos de cães para pesquisa de anticorpos contra raiva. Um deles, formado por 202 animais atendidos em hospitais veterinários, e um segundo composto de 149 animais provenientes de abrigos para animais errantes / não reclamados. Anticorpos contra raiva foram detectados em elevada proporção de animais do primeiro grupo $(89,1 \%)$, ao passo que apenas 38,3 $\%$ de animais do segundo grupo apresentavam anticorpos. Os títulos de anticorpos foram significativamente mais elevados entre animais com dono, e animais com idade entre 6-12 meses apresentaram títulos inferiores aos encontrados em grupos mais velhos.

A VCCL foi avaliada frente a diferentes cepas de vírus rábico isolados de diferentes espécies e localidades do Brasil, tendo conferido graus de proteção variáveis entre $15 \%$ e $100 \%$ dos camundongos inoculados (Hayashi et al., 1984). Os resultados deste estudo são sugestivos da existência de diferentes cepas de vírus rábico no Brasil, as quais foram classificadas em cinco grupos, com base nos estudos de proteção.

Também no Brasil, Timenetsky et al. (1985) avaliaram a imunidade citomediada em cães vacinados com a VCCL, submetidos a um regime de vacinação de 5 doses diárias mais um 'booster' 210 dias depois. Em todos os cães, a imunidade

\footnotetext{
${ }^{8}$ Titulação em camundongo do vírus utilizado no desafio: $10^{3.8} \mathrm{DL}_{50} / 0,03 \mathrm{ml}$
} 
citomediada foi detectada entre 8 e 15 dias aproximadamente, e em todos os animais também foram detectados anticorpos. $\mathrm{Na}$ revacinação, os títulos de anticorpos foram maiores que na primovacinação. Este autores questionam se a imunidade citomediada poderia ser obtida em cães primovacinados e com apenas uma dose da vacina.

$\mathrm{Na}$ atualidade, o Brasil já possui recursos para a produção de vacinas em cultivos celulares. Guidolin et al. (1983) descrevem o processo de desenvolvimento de vacinas anti-rábicas produzidas em cultivo celular no país, para uso em bovinos e caninos, indicando resultados satisfatórios dos testes de potência.

Dellepiane e Diaz (1987) apresentam uma revisão sobre a resposta imunitária à vacinação anti-rábica e vacinas anti-rábicas desenvolvidas até os dias atuais. Entre as vacinas de primeira geração, estão as vacinas anti-rábicas produzidas em tecido nervoso, incluindo a vacina Fuenzalida-Palacios. Dentre as vacinas de segunda geração, estão incluídas as vacinas com vírus adaptados a cultivos celulares primários e de células diplóides, estas últimas caracterizadas pela elevada resposta imunitária associada à segurança. Estão em desenvolvimento vacinas de vírions inteiros, vacinas de subunidades virais (em particular a glicoproteína - responsável pela infectividade, indução de anticorpos e citotoxidade mediada por células), e vacinas com recombinantes.

Fu (1997) cita que um novo mutante, o SAG-2, foi selecionado como um candidato para vacinação de animais, mostrando-se avirulento para roedores, raposas, gatos e cães adultos. Também já foram realizados experimentos com plantas transgênicas para expressarem antígenos do vírus rábico. Camundongos alimentados repetidamente com tomates transgênicos apresentaram produção de anticorpos anti-glicoproteina rábica. E a nucleoproteína do vírus rábico foi inserida no genoma de uma bactéria que infecta vegetais. Camundongos inoculados parenteralmente com o Clavibacter recombinante apresentaram resposta de anticorpos para a nucleoproteína do vírus rábico.

As vacinas produzidas com a amostra SAG-2 já foram testadas com diversas espécies de animais silvestres que não são alvo da vacinação anti-rábica, e que estão presentes em ecossistemas da Europa (Masson et al., 1996) e da África (Bingham et al., 1997), tendo em vista o futuro da vacinação oral em raposas e de outros canídeos 
silvestres, respectivamente. Em ambos os estudos, não se verificou patogenicidade da vacina para os animais passíveis de ingerirem as iscas utilizadas na vacinação oral das espécies alvo.

Fekadu et al. (1996) avaliaram a vacinação oral em cães com a amostra atenuada SAG-2, ou Street Alabama Gif, um mutante de baixa virulência da cepa $\mathrm{SAD}$, ou Street Alabama Dufferin. Os animais receberam a vacina oralmente na língua ou através de iscas, e $100 \%$ deles resistiu ao desafio com vírus de rua 180 dias após a vacinação. A vacina mostrou-se segura e efetiva para imunização oral de cães. Para esses autores, "o desenvolvimento de vacinas anti-rábicas orais seguras e efetivas, para cães errantes que não podem ser alcançados ou contidos para a vacinação parenteral, poderá facilitar a vacinação de uma grande proporção desses animais".

Em países da África e América Latina já foram realizados testes com iscas destinadas à vacinação oral contra a raiva em cães (Perry et al., 1988; Frontini et al., 1992).

Recentemente, um novo tipo de vacina anti-rábica produzida em cultivo celular livre de soro foi testado (Perrin et al., 1995), e foram avaliados "biovetores" com potencial de aumentar a imunogenicidade do antígeno rábico (Castignolles et al., 1996),

Com o desenvolvimento dessas novas técnicas, visualiza-se um novo horizonte para o controle da raiva, e o caso particular da vacinação oral de cães traz novas perspectivas para o controle da raiva em paises subdesenvolvidos, sobretudo devido às possibilidades de imunização de animais errantes, não acessíveis à vacinação parenteral.

\section{Vacinação anti-rábica}

Um exemplo de sucesso em campanhas de vacinação em massa contra raiva ocorreu no Peru (Chomel et al.,1988). Através de campanhas de vacinação, a raiva chegou a ser controlada em Lima na década de 70 , voltando a reaparecer na década de 80 , devido à falta de medidas de controle adequadas, e atingindo proporções de epizootia em 1982, quando foram registrados 1023 casos. A vacinação em massa foi então reintroduzida, mas focos enzoóticos persistiram, motivando a realização de um 
trabalho conjunto entre o ministério da Saúde do Peru, a Organização pan-americana de Saúde e outras duas instituições internacionais.

Na campanha realizada no Peru (Chomel et al., 1988), foram vacinados 270.000 cães (e aproximadamente 27.000 gatos) durante o período de um mês no ano de 1985 , o equivalente a $65 \%$ da população canina estimada. A vacina inativada foi produzida com a cepa PV 11 cultivada em células de embrião de hamster, sendo inativada pela beta-propiolactona, tendo como adjuvante o hidróxido de alumínio. Aplicou-se uma dose de $1 \mathrm{ml}$ pela via subcutânea. Como resultado da vacinação, o número de casos de raiva animal caiu de uma média de 292 casos anuais para três casos. Não foram notificados mais casos de raiva humana, em contraste com 13 casos registrados entre os anos de 1983 a 1985, antes da realização da campanha. Outro aspecto de grande importância foi que passados 12 meses da vacinação, $97 \%$ dos cães tinham títulos de anticorpos neutralizantes iguais ou superiores a 0,5 UI / $\mathrm{ml}$, e $87 \%$ possuíam títulos iguais ou superiores a $1,0 \mathrm{UI} / \mathrm{ml}$. Os cães estudados foram selecionados randomicamente, e $51 \%$ destes eram animais primovacinados. Não se verificou diferenças significantes entre os títulos de anticorpos de animais primovacinados e de animais previamente vacinados, aos 12 meses após a vacinação.

Chomel et al. (1988) citam ainda o contraste entre os resultados do estudo no Peru, e um outro na Tunísia, com a mesma vacina. No caso da Tunísia, $24 \%$ de 29 cães, acompanhados durante um ano, apresentaram títulos $\geq 0,5 \mathrm{UI} / \mathrm{ml}$. Os autores atribuem a diferença ao número de animais estudados e à metodologia. No Peru, amostras representativas constituidas de diferentes grupos de animais foram selecionadas ao longo do período de estudo, totalizando mais de 600 cães. O possivel efeito do parasitismo e má nutrição, explicação apontada para o estudo na Tunísia, não foram consideradas hipóteses prováveis, uma vez que também no Peru estas condições pareciam comuns, pois a maioria dos cães vacinados eram de áreas de baixo status socioeconômico.

Nas localidade de Castilla e León, na Espanha, considerada livre de raiva, mas que pode atuar como uma ponte de ligação entre a África (onde a raiva é endêmica) e a Europa (onde a raiva canina foi eliminada), são realizadas vacinações obrigatórias dos cães a cada dois anos, utilizando uma vacina anti-rábica com vírus Pasteur (PV) cultivado em células BHK-21, inativada pela beta-propiolactona, e 
adsorvida em hidróxido de alumínio. Esta vacina confere imunidade protetora por ao menos 2 anos, e conforme citam Delgado e Cármenes (1997), é a única vacina autorizada na maioria dos países da Europa. Os citados autores realizaram um estudo transversal para avaliar a resposta imune dos cães nas referidas localidades da Espanha, após a campanha de vacinação. Foram colhidas 156 amostras de soro num periodo de 12 meses entre 1993 e 1994.

Através do teste ELISA indireto, Delgado e Cármenes (1997) verificaram que $58,3 \%$ dos animais eram soropositivos (títulos iguais ou superiores a $0,5 \mathrm{UI} / \mathrm{ml}$ ), existindo diferenças significantes entre as duas localidades (50 e $77 \%$ ), indicando uma resposta limitada ao programa de vacinação. Não se verificou diferenças na soroprevalência quanto aos fatores idade, sexo, hábitat e uso do cão. As diferenças entre as duas localidades são atribuidas a possiveis diferenças nas estruturas e densidades populacionais.

Uma questão essencial para o controle da raiva em uma população canina é a proporção de animais a serem vacinados para o controle da raiva. A Organização Mundial de Saúde recomenda que $70 \%$ da população seja imunizada para eliminar ou prevenir surtos de raiva. Coleman e Dye (1996) estimaram esta proporção crítica entre $39 \%$ e $57 \%$, para valores de reprodutibilidade basal (R0) variando entre 1,62 e 2,33 . As estimativas foram realizadas através de simulações com dados de quatro surtos em áreas urbanas e rurais dos Estados Unidos, México, Malásia e Indonésia, e indicam que o valor recomendado pela OMS seria suficiente para prevenir um grande surto de raiva em $96,5 \%$ das ocasioes.

\subsubsection{Avaliação da vacina inativada produzida em cérebro de camundongos lactentes (VCCL) em condições naturais}

No Brasil, a resposta imunitária de cães primovacinados à VCCL foi avaliada por Germano et al. (1982). Estes utilizaram 20 cães domiciliados, com 4 a 6 meses de idade, sem antecedentes de vacinação e sem anticorpos detectáveis por soroneutralização (SN) e imunofluorescência (IF) indireta. A vacina, inativada pela beta-propiolactona e produzida pelo TECPAR, tendo grau de potência de 48.350 $\mathrm{DL}_{50}$ (Método de Habel), foi aplicada em uma dose subcutânea de $2 \mathrm{ml}$. A 
imunidade medida através da SN apresentou ascensão lenta e de pequena magnitude, e um declínio rápido, já aos 45 dias de vacinação, atingindo neste curto período níveis que só ocorreram aos 24 meses no estudo realizado por Sikes et al. (1971). Avaliando os resultados da pesquisa, os autores ressaltaram preocupação com os baixo titulos observados, em especial por considerarem que "a medida mais eficiente para o controle da raiva urbana consiste na realização de campanhas de vacinação em massa da população canina, e que o intervalo de tempo preconizado entre uma vacinação e outra é de 12 meses".

No município de Araçatuba, estado de São Paulo, realizou-se a pesquisa de anticorpos contra raiva em cães em uma área de foco de raiva, nove meses após a realização de uma campanha de vacinação; 32 \% dos cães não eram vacinados contra raiva. Aproximadamente $47 \%$ dos animais apresentavam baixos títulos de anticorpos $(<1: 5)$, dos quais $53,3 \%$ haviam recebido 2 ou mais doses da vacina. A maioria dos cães primovacinados apresentavam baixos títulos de anticorpos (Silva et al., 1996).

Um outro trabalho realizado em São Paulo, por Almeida et al. (1997) avaliou a presença de anticorpos contra raiva em cães dos municípios de São Paulo e Paulínia, nos anos de 1994 a 1996, 12 meses após a realização da campanha de vacinação anti-rábica nos respectivos lugares e 30 dias após o reforço da vacinação No total, foram testadas 259 amostras de soro. No município de São Paulo, todos os cães foram vacinados com um mesmo lote da VCCL, com título de 1,4 UI / dose (método do NIH). No caso de Paulínia, foram utilizados diferentes lotes do mesmo tipo de vacina, todos aprovados pela mesma técnica (os títulos não foram citados no trabalho).

Almeida et al. (1997) verificaram um acentuado decréscimo na freqüência de animais não reagentes após a realização da vacinação de reforço. Doze meses após a última campanha de vacinação anti-rábica, apenas 25 a $26,2 \%$ dos cães eram reagentes (títulos iguais ou superiores a $0,5 \mathrm{UI} / \mathrm{ml}$ ). Após o reforço, a frequêencia de reagentes passou a variar entre 64 e $72,7 \%$. O estado nutricional dos animais não apresentou associação com a reatividade avaliada através da sorologia, mas constatou-se uma associação positiva entre o número de vacinaçð̃es anteriores e a resposta imune dos cães. Os autores concluem que a vacina utilizada não confere 
imunidade prolongada e que o estado nutricional não é fator preponderante na supressão.

Hayashi et al. (1985 e 1986) discutem aspectos da produção e utilização da VCCL no Brasil. Segundo estes, o uso da VCCL se ajusta bem à realidade epidemiológica e econômica do país (por suas características de custo de produção, potência e estabilidade), tendo produzido importantes mudanças no comportamento epidemiológico da raiva no Brasil e em países da América Latina. Comparativamente, as vacinas purificadas e concentradas, produzidas em cultivos celulares, possuem baixo nivel de impurezas e elevada potência imunogênica. Entretanto, embora estas últimas estejam em uso crescente em diversos países que já atingiram o controle da raiva canina, apresentam elevado custo de produção.

Estudos realizados em condições naturais na Indonésia (Hirayama et al., 1990) e no México (Eng et al., 1993) indicaram um rápido decréscimo no título de anticorpos anti-rábicos em cães vacinados com a VCCL. Elevada proporção de animais vacinados apresentaram baixos títulos de anticorpos já aos 3-4 meses após a vacinação. No caso do México, ocorreu falha de vacinação em $46 \%$ dos casos de raiva em cães com registro de vacinação verificado.

Hirayama et al. (1990) sugerem que uma única vacinação anual é insuficiente para manter os níveis de anticorpos protetores contra a raiva (na Indonésia foram usadas a VCCL e uma vacina inativada produzida em cérebro de caprinos), e citam que a imunização com duas doses em cães com menos de um ano mostrou-se efetiva, produzindo forte imunidade, embora seja difícil a utilização de reforço em campanhas de vacinação em massa.

Para explicar a baixa imunogenicidade das vacinas anti-rábicas utilizadas durante uma epizootia de raiva no México (VCCL e uma vacina inativada produzida em cultivo celular), Eng et al. (1993) avaliaram as hipóteses de (1) via de administração incorreta, (2) resposta imune limitada (fatores nutricionais e sanitários), (3) falhas na conservação da vacina, e (4) falta de potência inerente à vacina. Considerando os aspectos investigados, a pobre imunogenicidade das vacinas foi a hipótese que melhor explicou o problema. Os cães do México, a maioria dos quais mal nutridos, e os cães que foram testados em condiçð̃es de laboratório nos Estados Unidos, responderam de forma similar às vacinas. Por outro 
lado, cães do México que foram vacinados com uma outra vacina com vírus modificado soroconverteram, a maioria com títulos adequados, indicando que eles podem responder adequadamente às vacinas anti-rábicas.

Eng et al. (1993) verificaram que apenas cães que receberam mais de quatro doses de vacina apresentavam títulos adequados de forma consistente, sugerindo serem necessárias múltiplas doses da VCCL para assegurar uma proteção adequada. Estes comentam ainda os resultados de um estudo realizado na Argentina (Larghi et al., 1986), cujos autores sugerem que a VCCL com um valor antigênico mínimo de 0,3 pode ser utilizada com sucesso para o controle da raiva no ambiente urbano, embora no caso daquele país tenham sido utilizadas vacinas com valor antigênico médio maior que 1 para a maioria dos anos de vacinação, além do fato de que o controle da raiva só foi atingido após diversos anos de vacinação.

Entretanto, não é apenas com a VCCL que são registrados problemas de imunização e falhas vacinais. Na literatura há diversos registros de episódios, alguns dos quais são mencionados a seguir, a título de ilustração.

Bourhy et al. (1988) descrevem 11 casos de raiva em cães vacinados com diversos tipos de vacina inativada produzida em cultivo celular, sem explicação aparente, onde foram descartadas hipóteses como baixa potência, más condições de saúde dos animais ou cepa viral para qual as vacinas utilizadas não induzem proteção. Os casos de raiva ocorreram entre 4,5 e 11,5 meses (em média 8,7 meses) após a última vacinação. Nove cães eram primovacinados, e três deles eram crias de cadelas sabidamente vacinadas (possível interferência da imunidade materna).

Okoh (1982) relata a ocorrência de 14 casos de raiva em cães vacinados com vacina de vírus modificado, 10 dos quais resultantes de aparente falha vacinal, e quatro casos possivelmente induzidos pela vacina. Quase todos os cães eram adultos e todos eles tinham dono.

Casos de possivel falha na vacinação de cães no Texas são discutidos por Clark et al. (1981). Estes autores fazem importantes considerações sobre as observações que são feitas em vacinação anti-rábica experimental e em condições naturais. ... "Experiências a campo em algumas instâncias invalidaram conclusões derivadas unicamente de experimentos laboratoriais."... Em condições de campo, "há muitas variáveis que podem afetar adversamente as respostas imunológicas". 
..."As falhas de vacinação enfatizam o fato de que a proteção contra raiva não é absoluta". ..."Fatores como a falta inerente de potência, perda de potência devido à manipulação incorreta, imprópria administração, ou não responsividade imunológica do animal recipiente podem resultar em imunidade inadequada". $\mathrm{O}$ tempo insuficiente após a vacinação também deve ser considerado.

\subsubsection{A vacinação anti-rábica canina no Brasil e o Programa Nacional de Profilaxia da Raiva}

O Programa Nacional de Profilaxia da Raiva (PNPR) foi implantado no Brasil no ano de 1973, tendo como prioridade as atividades de (1) tratamento profilático humano; (2) vacinação anti-rábica canina; (3) diagnóstico laboratorial; (4) educação em saúde; (5) captura de cães; (6) vigilância epidemiológica (Gomes, 1980; Gomes, 1983).

Segundo Gomes (1983), a vacinação anti-rábica canina é prioritária devido ao cão ser responsável pela transmissão de aproximadamente $90 \%$ dos casos de raiva humana, além de se observar que quando há redução na incidência de raiva canina, também ocorre diminuição na incidência de raiva nas outras espécies, indicando ser o cão elemento essencial no ciclo da raiva em ambiente urbano.

Belotto (1988) cita que estudos realizados na fase preliminar PNPR, entre os anos de 1974 e 1976, indicaram uma razão média de 1 cão para cada 10 habitantes nas áreas urbanas do Brasil. Gomes (1983) também cita que o tamanho da população canina corresponde a $10 \%$ da população humana, variando entre $1: 6$ e $1: 14$ em estudos realizados em diferentes estados.

O PNPR é coordenado nacionalmente pelo Ministério da Saúde, através da Fundação Nacional de Saúde. Belotto (1988) e Gomes (1983) apresentam uma descrição geral da organização e funcionamento da vacinação anti-rábica a partir do início do PNPR, além das outras atividades que fazem parte do programa.

Segundo Belotto (1988), no Brasil preferiu-se a vacinação em massa em relação à eliminação de cães errantes, por motivos que vão da maior simplicidade à maior aceitação por parte da população, que apóia e participa da execução das campanhas. 
Schneider et al. (1996) citam que "a captura de animais durante o controle de foco passou a ser considerada fundamental, mas a captura de rotina em áreas urbanas não demonstrou ser sempre necessária para que se consiga o controle da enfermidade. Curitiba, que foi a primeira cidade a conseguir controlar a raiva no Brasil, não realizava captura sistemática. Essa estratégia provavelmente depende da realidade local".

Entre os anos de 1974 e 1980, na maioria das cidades do Brasil a vacinação era realizada por vacinadores que faziam visitas domiciliares, o que deixou de ocorrer devido a problemas diversos envolvendo aspectos operacionais e de divulgação. A partir de 1981, seguindo a estratégia adotada para o controle da poliomielite, teve início a realização de campanhas de vacinação anti-rábica em um único dia, após a obtenção de sucesso em experiência efetuada em duas cidades (Belotto, 1988).

As campanhas de vacinação em massa são realizadas em um dia nacional de vacinação anti-rábica dos cães. As vacinas, elaboradas em cérebro de camundongo lactente e inativadas pela beta-propiolactona, são produzidas por um único laboratório nacional, e o controle de qualidade é realizado por laboratório do Ministério da Agricultura. As campanhas de vacinação envolvem os serviços de saúde pública federal, estadual e municipal, além de contar com a participação das forças armadas e outros seguimentos da sociedade. Estas têm como meta vacinar ao menos $80 \%$ da população canina de cada cidade, e cães com idade a partir de 1 mês são vacinados anualmente. A acentuada diminuição nos casos de raiva canina, num período de cinco anos da década de 80 , é atribuída ao aumento no número de animais vacinados (Belotto, 1988).

Outro fator importante a se observar nas estratégias de vacinação anti-rábica da população canina, é o comportamento dos proprietários de cães. Segundo Belotto et al. (1977), apenas $5 \%$ dos proprietários de cães vacinam os seus animais por iniciativa própria, comportamento mais limitado às classes de maior poder aquisitivo e com maior conscientização sobre o problema. Um dado que reforça este aspecto são os resultados de um estudo realizado em Araçatuba / SP, onde todos os cães vacinados o foram em campanha (Silva et al., 1996). 
Considerando a importância de um melhor conhecimento da organização e funcionamento das campanhas de vacinação anti-rábica canina no Brasil, apresentase a seguir a descrição das fases de uma campanha, apresentada por Belotto (1988):

"As campanhas têm três niveis de organização - federal, estadual e municipal, cada um com responsabilidades definidas.

A nivel federal: (1) coordenação da produção, aquisição e distribuição de vacinas para os estados; (2) produção de material para promoção nacional da campanha através dos diversos meios de publicidade; e (3) colaboração com os outros setores governamentais, tais como Ministério da Agricultura e Educação, e forças armadas.

A nivel estadual: (1) organizar com outras instituiçðes oficiais e comunidade as respectivas participações na campanha, com respeito a pessoal, veículos e demais detalhes; (2) providenciar material para vacinação e publicidade, particularmente para pequenas cidades ou localidades, as quais não podem realizar tais acertos sozinhas; e (3) armazenar as vacinas e distribui-las para o nivel municipal

A nivel municipal: (1) Planejar, executar e avaliar a campanha em sua área; (2) providenciar a localização dos postos; e (3) treinar os vacinadores e demais pessoal envolvido na campanha.

A campanha é realizada no início da primavera, no último sábado do mês de setembro, entre 8:00 e 17:00 h. Os postos de vacinação são localizados em unidades de saúde, escolas, clubes, clinicas veterinárias particulares, quarteirões e outras áreas públicas. Os postos são distribuídos de acordo com a densidade da população canina, de modo a vacinar em torno de 250 a 300 cães em cada posto durante um dia. A distância entre os postos também é importante, e os proprietários podem caminhar com os seus cães até os postos sem dificuldades. Postos móveis são usados em áreas com baixa densidade de cães.

Em cada posto, há ao menos duas pessoas, uma das quais atua como vacinador, e a outra realiza o registro e algumas vezes auxilia os proprietários a controlarem os seus animais e a prepará-los para vacinação. Para cada dez postos há um supervisor, o qual lida com eventuais problemas que surjam durante a vacinação. Este tem à disposição um veiculo para deslocamento e para transportar vacina adicional e outros itens até os postos, quando necessário.

Os vacinadores recebem dois dias completos de treinamento, nos quais adquirem conhecimentos gerais sobre raiva, técnicas de vacinação dos cães e outros conhecimentos práticos. Durante 15 dias antes da vacinação, mensagens sobre a campanha de vacinação e prevenção da raiva humana e animal são 
veiculadas pela televisão e rádios. Notícias são impressas em contas de gás, telefone e eletricidade. Panfletos contendo informações gerais e localização dos postos de vacinação são distribuídos em escolas, unidades de saúde, agências de correios, supermercados, e em outros estabelecimentos. No dia da vacinação, a localização dos postos são impressas nos jornais mais populares."

Algumas cidades brasileiras, a exemplo do município de São Paulo, já conseguiram controlar a raiva no ambiente urbano, e no caso de Curitiba no Paraná, após o controle da raiva, a vacinação em massa foi suspensa, mantendo-se apenas as medidas de vigilância e controle de animais errantes (Schlogel et al., 1985; Konolsaisen, 1985; Monteiro et al., 1992).

Diversos trabalhos discutem a distribuição e o comportamento da raiva no Brasil, particularmente após a implantação do PNPR (Nagata et al., 1980; Belotto, 1985; Gomes, 1985; Konolsaisen, 1985; Schlogel et al., 1985; Hayashi et al., 1986; Schneider, 1990; Monteiro et al., 1992), assim como aspectos da exposição humana a agressões por animais e tratamento anti-rábico (Tornero e Shibayama, 1974; Moreira et al., 1976; Liechti e Loureiro, 1979; Liechti, 1982; Liechti e Loureiro, 1982; Pinto e Alleoni, 1986). A análise dos citados trabalhos torna evidente o acentuado decréscimo no número de casos de raiva animal e humana com a implantação do PNPR, embora também fique evidente a existência de inúmeros problemas, requerendo ajustes no programa. 


\subsection{Caracterização do problema da raiva na cidade de Recife}

A raiva é atualmente um problema endêmico em Recife. Nos últimos anos, casos de raiva animal, com predominância da raiva canina, foram diagnosticados na maioria dos meses do ano, e também ocorreram casos de raiva humana.

Após um periodo de acentuado declínio nos casos de raiva canina em Recife, com a implantação de medidas preconizadas pelo PNPR, a incidência de raiva canina não tem apresentado tendência de declínio, ao contrário do êxito do programa em outros estados, especialmente das regiões Sul e Sudeste, caracterizando a existência de disparidades regionais, como acontece com outras questões de saúde pública. A cidade de Recife é considerada área de alto risco para a raiva (SCHNEIDER, 1990).

Ao contrário, uma análise de dados obtidos no Centro de vigilância animal da Prefeitura da cidade de Recife (CVA/PCR) e no LAPA (Ministério da Agricultura), indicam uma nítida tendência de aumento do número de casos de raiva canina em Recife na década de 90. A partir de 1991, ano após ano, de maneira invariavelmente consistente, o número de casos de raiva canina diagnosticados laboratorialmente vem aumentando, e os mesmos estão amplamente distribuídos na cidade de Recife, envolvendo inclusive bairros do centro da cidade (Figura 1). 
Figura 1: distribuição dos casos de raiva na cidade de Recife, segundo os bairros, entre os anos de 1991 e 1997.

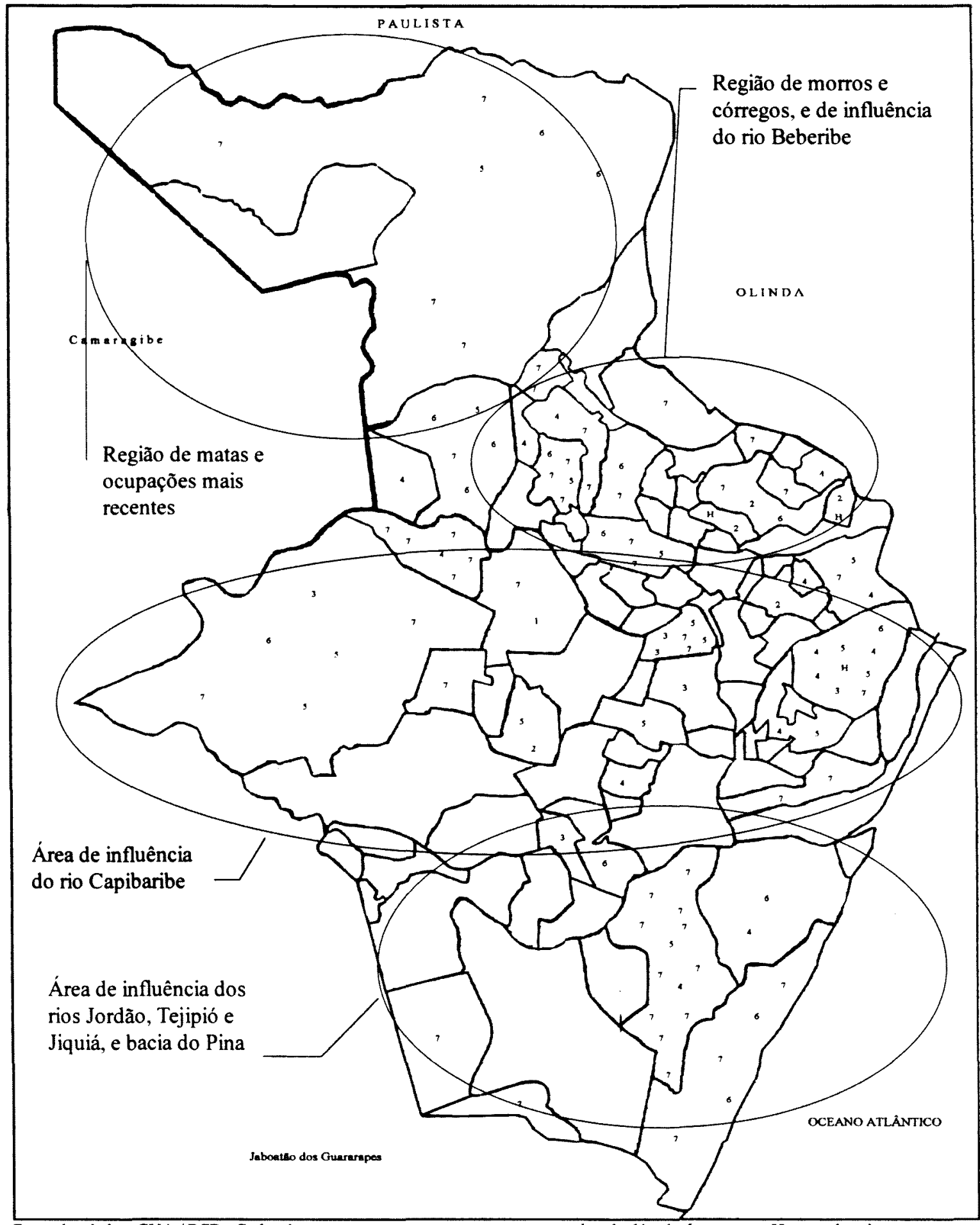

Fonte dos dados: CVA / PCR. Cada número representa um caso no ano respectivo da década de noventa; $\mathrm{H}$ : caso de raiva humana. Os números nåo representam a exata localização espacial dos casos, mas apenas o bairro onde os mesmos foram notificados 
A maioria dos casos de raiva mais recentes ocorreram em cães com dono, muitos deles envolvendo cães domiciliados e vacinados, segundo informações dos proprietários. Ressalta-se que o aumento na remessa de material para diagnóstico laboratorial não explica este comportamento.

O que parece existir em comum entre as áreas com maior freqüência de casos de raiva canina é a existência de populações mais pobres, residindo geralmente em áreas subnormais ou Favelas. Grande parte das favelas de Recife se desenvolveram em áreas adjacentes a rios, lagoas, canais, córregos ou em morros, impróprias para edificações regulares, e que foram invadidas por populações mais carentes. Dentre essas áreas, merecem destaque as áreas próximas ao rio Capibaribe, que corta a cidade no sentido oeste para Leste; as áreas cortadas pelos rios Jordão, Tejipió e Jiquiá, com influência nos setores sul e sudoeste da cidade; as áreas próximas ao rio Beberibe, situadas ao norte da cidade, nas proximidades da divisa com o município de Olinda; e finalmente, todas as áreas de morros e córregos situadas na zona norte de Recife.

Mesmo em bairros habitados por famílias de elevado poder aquisitivo, existem aglomerados de residências pobres, situados geralmente ao longo de canais, na forma de palafitas e barracos.

Basta percorrer a cidade de Recife, conhecida como a "Veneza brasileira", ao longo dos seus rios, e uma imagem comum será presenciada: em primeiro plano, veremos os rios e as favelas às suas margens, e ao fundo, os grandes edificios, cada vez mais freqüentes na paisagem recifense.

Nessas áreas, os casos de raiva não estariam ocorrendo necessariamente em favelas. Mas lá existem elevadas densidades caninas, com baixos níveis de restrição, o que se explica pelo elevado adensamento populacional em áreas limitadas, com muitas famílias de baixa renda, habitando residências cujo tipo favorece a não restrição dos cães, como já foi discutido anteriormente.

Assim, nestas localidades, o vírus rábico provavelmente encontra condições adequadas para a sua manutenção e transmissão. E como os cães não restritos podem percorrer quilômetros em busca de alimentos e acasalamentos (Beck, 1973), o vírus pode chegar aos outros setores da cidade, dentro do raio de ação dos cães, sendo esta difusão condicionada pelas barreiras naturais ou criadas pelo homem. Nestes locais, 
embora com mais cães sujeitos a algum tipo de restrição, os cães sob maior risco seriam aqueles que têm algum acesso ao ambiente extra-domiciliar, ou que embora presos, podem ter contato com outras cães na rua através de grades ou portões.

Resultados de inquéritos epidemiológicos apontam para a existência de casos de raiva além dos que foram notificados, a julgar por diferentes tipos de evidências e também por informações fornecidas pela população. Esses não foram investigados, possivelmente devido ao desconhecimento da população quanto à conduta em caso de suspeita de raiva, e também pela falta de um sistema eficiente de vigilância epidemiológica.

Assim, o número real de casos de raiva deve ser bem maior do que o conhecido oficialmente, o que é reforçado pelo fato de que muitas pessoas enterram os seus cães mortos sem encaminharem a investigação da causa de morte. Em áreas carentes, através de entrevistas, constatamos a existência da prática de jogar em rios, canais, córregos e marés os animais mortos (Figura 2), e nessas áreas as pessoas acham que alguns desses cães morreram de raiva.

Figura 2: Homem arremessando cão morto no Rio Capibaribe (Ilha Joana Bezerra).

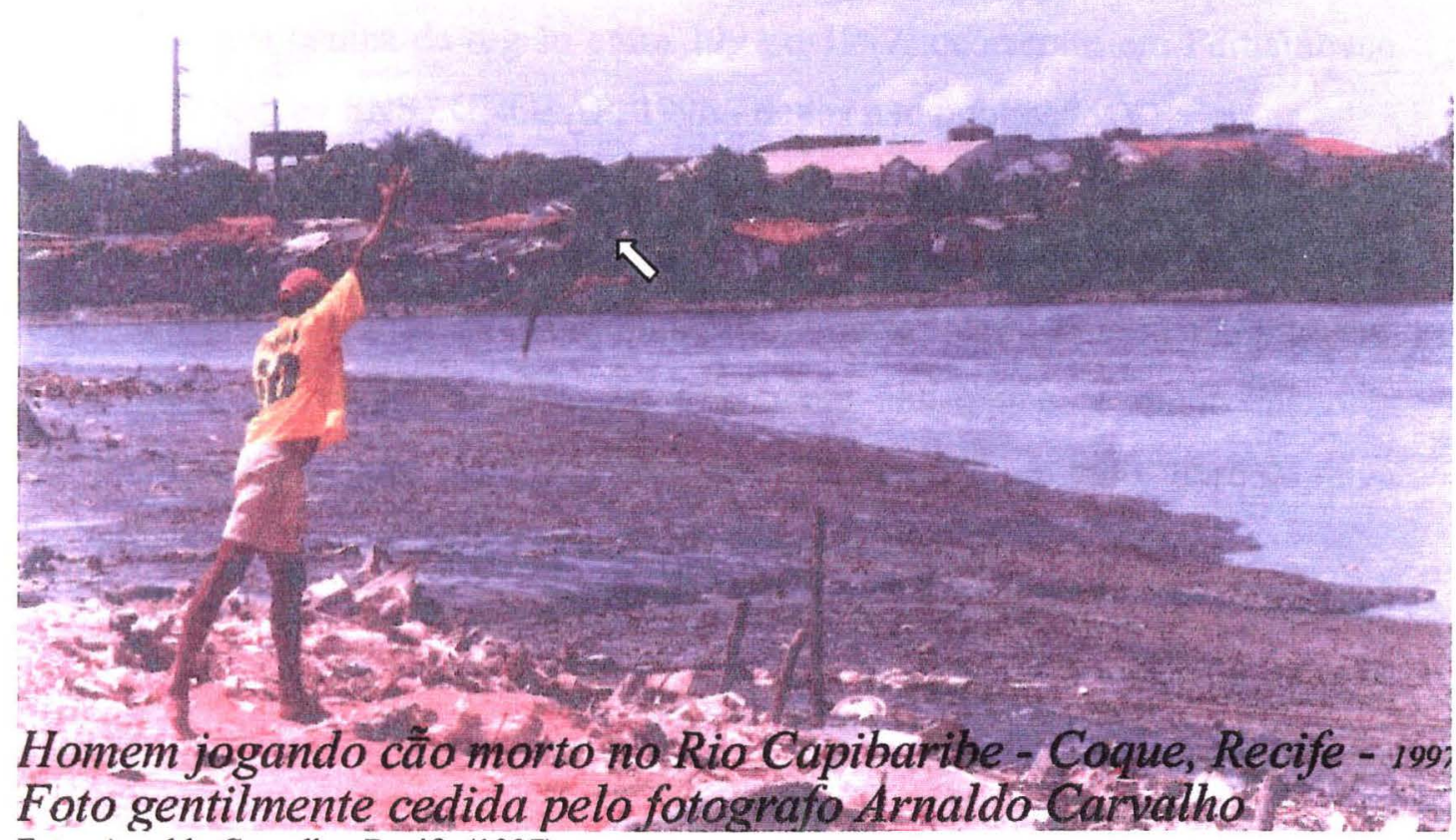

Foto: Arnaldo Carvalho, Recife (1997). 
E finalmente, além dos casos de raiva felina também existentes anualmente, que se somam aos casos de raiva canina confirmados, muitos cães são atropelados diariamente em via pública, sem que posteriormente sejam examinados. Não se pode descartar a hipótese de que uma fração dos mesmos pudesse estar infectada com o vírus rábico, já que animais doentes deambulam e apresentam transtornos neurológicos, tendo portanto maiores chances de serem vítimas de acidentes de trânsito.

O número de casos de raiva humana e animal registrados no Nordeste e em Pernambuco é ainda mais preocupante quando consideramos que o Brasil aumentou a sua participação proporcional no número de casos de raiva humana nas Américas entre os anos de 1989 e 1991 - 50/268 casos: $18,6 \%$; 54/235 casos: $23 \%$; 70/214 casos: $32,7 \%$, respectivamente (OPS, 1993).

A região Nordeste tem participação importante neste quadro, com tendência de crescimento. Esta foi responsável por $61 \%$ dos casos de raiva humana no Brasil entre os anos de 1986 e 1997; entre 1992 e 1997, 24,6\% dos casos de raiva canina, e $29 \%$ dos casos de raiva felina do Brasil, ocorreram no Nordeste. O estado de Pernambuco foi responsável por $17,4 \%$ de todos os casos de raiva humana da região Nordeste entre 1986 e 1997, participando de forma relativamente constante; e $14,4 \%$ dos casos de raiva canina da região entre 1992 e 1997, ocorreram em Pernambuco (Ministério da Saúde / FNS / CNCZAP, 1998 - dados não publicados).

A eliminação da raiva canina em Recife favoreceria uma acentuada redução no número de pessoas que recebem o tratamento, e no número de doses de vacina $\mathrm{e}$ de soro anti-rábico utilizadas na população humana, com benefícios visíveis: menores riscos de reações adversas ao tratamento anti-rábico, e muito menores custos com esse tratamento, além da maior tranqüilidade que o estado 'livre de raiva canina' propiciam à população e aos serviços de saúde pública.

Pode-se tomar como exemplo de tais beneficios, o protocolo de tratamento anti-rábico em humanos adotado no município de São Paulo (SÃO PAULO, 1994), livre da doença desde a década de 80 , o qual considera o conceito de diferentes áreas de risco, além do tipo de animal agressor. 
Bogel e Meslin (1990) avaliaram que do ponto de vista de beneficios e da economia de recursos, a eliminação da raiva canina é mais efetiva do que a intensificação e modernização do tratamento humano.

As principais medidas de controle da raiva animal, adotadas pelo CVA/PCR, consistem em campanhas de vacinação da população canina e felina no mês de setembro, seguindo calendário anual do Ministério da Saúde, captura de cães errantes, e controle em áreas de foco. Apesar do empenho do CVA/PCR , a instituição enfrenta difículdades comuns aos serviços de saúde pública no Brasil, além do antagonismo das associações que visam à proteção dos animais, contrárias à eliminação de cães.

É evidente a destacada importância dos cães no processo de transmissão da raiva nos centros urbanos, e justificada a ênfase que deve ser dada ao estudo da população canina nas investigações direcionadas ao controle da raiva.

Em Recife, tem sido adotada a razão de 1 cão para cada 10 habitantes, para fins de planejamento e avaliação de campanhas de vacinação anti-rábica canina, incluindo a estimativa da cobertura de vacinação. Entretanto, a OPS (1993) recomenda a substituição desse indicador geral, e que sejam realizados estudos da população canina específicos para a localidade.

Os resultados de dois estudos preliminares relacionados ao presente projeto indicavam a estimativa de 1 cão para cada 6,6 habitantes em Recife, um número expressivamente maior do que o oficial. A população canina de Recife poderia ser, então, muito maior do que se admite, o que tem importantes implicações para o planejamento das atividades de controle da população canina, bem como para o planejamento e avaliação das campanhas de vacinação anti-rábica. Tais implicações não se estendem apenas ao problema da raiva, mas também ao controle de outras zoonoses e problemas ambientais e de saúde pública ligados ao cão.

Atualmente, a raiva canina persiste em diversos paises do mundo, em especial nos paises subdesenvolvidos. Esses países têm em comum a existência de peculiaridades socioeconômicas e culturais, condicionantes de características ecológicas da população canina, as quais são desfavoráveis à eliminação da raiva canina. Dentre elas, destacam-se as elevadas densidades de cães e a pouca restrição 
e e cuidados com os animais, favorecendo a disseminação do vírus rábico, mesmo com o emprego de medidas clássicas de controle da doença.

Em função deste quadro, a Organização Mundial de Saúde (OMS) passou a indicar a realização de estudos ecológicos da população canina, em particular nos grandes centros urbanos onde a raiva ainda persiste. A OMS coordenou estudos dessa natureza no Equador, Nepal, Sri Lanka e Tunísia (WHO, 1992), e outros estudos ecológicos foram realizados na América do Sul e Ásia. Estudos dessa natureza são considerados essenciais ao planejamento e avaliação de estratégias de controle e eliminação da raiva canina, favorecendo, em conseqüência, a eliminação da raiva humana, que tem o cão como principal transmissor.

Conclusð̃es particularmente importantes dos estudos ecológicos e de manejo das populações caninas fazem parte do oitavo relatório do comitê de especialistas em raiva da OMS (WHO, 1992):

A colheita de dados e pesquisas operacionais devem continuar em outras áreas e países com diferentes condições ecológicas e sociais; recomendase drásticas mudanças nas medidas de controle da raiva, relativamente àquelas adotadas pela maioria das autoridades de saúde em diferentes países; não há evidências de que a eliminação de cães tenha efeitos duradouros com impacto significativo sobre as densidades populacionais caninas ou disseminação da raiva. A renovação populacional canina pode ser tão alta que, mesmo as mais elevadas taxas de remoção registradas (em torno de $15 \%$ da população canina), são facilmente compensadas pelos aumentos nas taxas de sobrevivência. Adicionalmente, a remoção de cães pode não ser aceita por comunidades locais. Assim, a menos que estudos ecológicos e socioculturais demonstrem a viabilidade da eliminação de cães, a mesma não deve ser adotada em programas de controle de larga escala.

Até recentemente, a eliminação de animais, objetivando reduzir as suas densidades populacionais, era considerado o único meio de controle da raiva em animais silvestres. Cita-se como exemplo, o programa de controle de animais 
silvestres na fronteira entre México e Estados Unidos na década de 50 (PRESSNALL, 1957). Atualmente, entretanto, diversos trabalhos discutem a viabilidade de diferente métodos de controle da raiva, em especial a vacinação e a eliminação de animais, com os seus resultados variados (ANDERSON et al., 1981; COYNE et al., 1989; AUBERT, 1994).

Uma questão fundamental emerge: quais os níveis requeridos de imunização e / ou eliminação de uma população em particular, para a eliminação da raiva ? O uso de modelagem matemática é particularmente útil em tais situações, e estudos dessa natureza já foram realizados com animais silvestres, possibilitando a avaliação da viabilidade do emprego de diferentes medidas (COYNE; SMITH; MCALLISTER, 1989).

A vacinação por exemplo, tem dois principais efeitos no controle e erradicação de doenças infecciosas. Um efeito direto, através do qual uma fração da população hospedeira suscetível é removida diretamente para a classe imune, devido à imunização com sucesso. E um efeito indireto, pois um menor número de infecções implicará numa menor força de infecção, $\lambda$. Os animais suscetíveis estarão indiretamente protegidos, a um certo grau, pela diminuição daqueles animais que podem disseminar a infecção. A imunização em massa em essência, diminui a taxa de reprodutibilidade basal - Ro (ANDERSON e MAY, 1992).

Uma importante conseqüência desses efeitos indiretos é que não é necessário imunizar todos os indivíduos para erradicar a infecção. Uma vez que a cobertura de vacinação atinge um determinado nível, o agente etiológico da doença será incapaz de manter a reprodutibilidade basal acima de uma unidade - condição necessária para a sua perpetuação (ANDERSON e MAY, 1992). A Figura 3 a seguir ilustra este aspecto. 
Figura 3: proporção de cobertura de vacinação ao nascer requerida para interromper a transmissão da doença

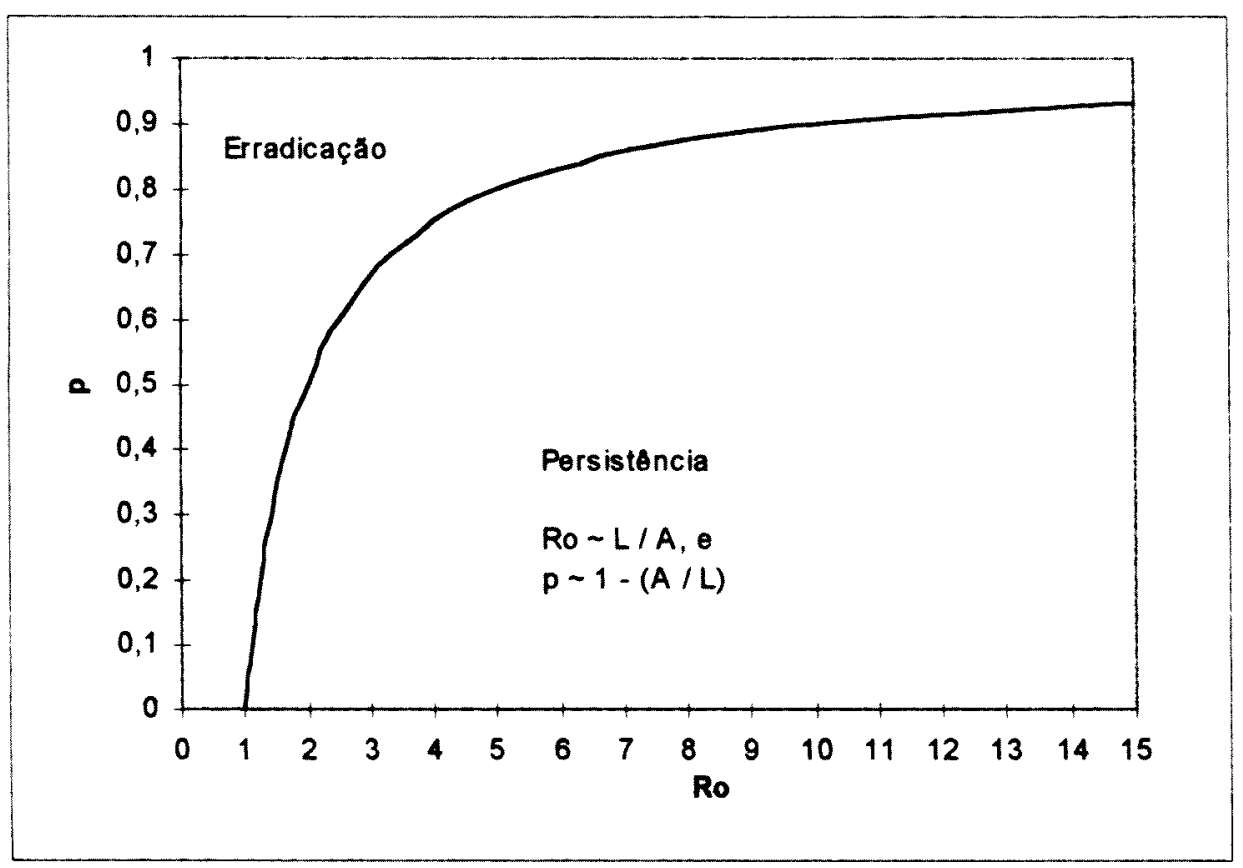

Figura adaptada de Anderson e May (1992). L = expectativa de vida; $A$ = idade de aquisição da infecçăo

Em Recife, resultados preliminares da presente investigação e do estudo piloto indicaram a estrutura etária de uma população canina jovem na cidade. Parecem existir elevadas taxas de renovação populacional, pois aproximadamente 33 \% dos animais vacinados anualmente em campanhas de vacinação anti-rábica estariam recebendo a vacina pela primeira vez.

Com tão elevadas taxas de renovação da população canina, cresce a exigência de maiores esforços para o controle da raiva:

(1) a renovação populacional de aproximadamente $30 \%$ implica na existência de uma elevada fração de suscetíveis à raiva durante boa parte do ano, até a chegada da campanha anual de vacinação no mês de setembro. E este ciclo se repete continuamente. Mesmo que se obtivessem elevadas coberturas de vacinação após a realização da campanha, ao longo do ano, como o processo de renovação 
populacional é contínuo, a mortalidade tenderia a reduzir a fração de animais imunes , e os nascimentos tenderiam a aumentar a fração de suscetíveis na população, resultando em níveis de imunidade populacional insuficientes para interromper o ciclo de transmissão da raiva;

(2) Em menos de quatro anos a maioria da população canina é renovada, e não se consegue manter uma população com elevada proporção de animais que receberam múltiplas doses da vacina anti-rábica.

Estudo realizado recentemente no México (ENG et al., 1994), citado anteriormente, indica que em condições de "campo", uma elevada proporção de cães consistentemente protegidos contra um desafio com o vírus rábico, se vacinados com vacina inativada produzida em cérebro de camundongos lactentes, só é obtida em cães que receberam quatro ou mais doses da vacina. Uma elevada proporção de cães primovacinados não desenvolveram títulos de anticorpos suficientemente altos, e dentre os que desenvolveram, muitos já estavam desprotegidos contra o desafio com o vírus rábico no intervalo de poucos meses. Ressalta-se que tais resultados não foram atribuidos a problemas nutricionais ou de saúde dos cães, mas sim a uma inerente falta de potência das vacinas.

(3) A renovação populacional elevada ganha ainda mais relevância após uma outra constatação. Ao longo dos últimos anos, os níveis de cobertura de vacinação anti-rábica em Recife mantiveram-se constantes e relativamente elevados, mas não alcançaram a marca de $80 \%$ da população canina estimada oficialmente. Não parece ser óbvia a explicação para esse fato . E como já foi mencionado, mesmo que a cobertura de vacinação de $80 \%$ fosse atingida na campanha, e mesmo que a eficiência da imunização fosse de $100 \%$, e que a duração da imunidade fosse de um ano, nos meados da campanha seguinte apenas $56 \%$ dos cães ainda estariam protegidos (realizando uma estimativa linear e simplificada).

Entretanto, há inúmeras evidências da possível ineficiência do processo de imunização anti-rábica, além de problemas com a distribuição espacial dos postos.

No ano de 1993, foi realizada uma investigação durante a campanha de vacinação anti-rábica, a qual viria a se constituir em ponto de partida para a presente 
pesquisa. Como uma das conclusões do estudo de 1993, transcreve-se abaixo texto incluído em relatório que foi enviado à Diretoria de Epidemiologia e Vigilância Sanitária / Secretaria de Saúde do Estado de Pernambuco:

\section{"Animais primo vacinados:}

$\mathrm{Na}$ campanha de 1993, $28 \%$ dos cães estavam sendo vacinados pela primeira vez. As 6 regionais apresentaram as seguintes proporções de cães primo vacinados: $I=50 \% ; I I=27$ $\% ;$ III $=33 \% ; \mathrm{IV}=28 \% ; \mathrm{V}=21 \% ; \mathrm{VI}=26 \%$. O limite inferior do intervalo de $95 \%$ de confiança para a idade dos cães primo vacinados foi igual a 10,6 meses.

Para os gatos, $45 \%$ estavam sendo vacinados pela primeira vez, e de acordo com as regionais, as proporções foram: $I=50 \%$; $\mathrm{II}=50 \% ; \mathrm{III}=60 \% ; \mathrm{IV}=0 \% ; \mathrm{V}=86 \% ; \mathrm{VI}=50 \%$. O valor 0 $\%$ da regional IV pode ser devido ao menor número de proprietários de gatos entrevistados, o que ocorreu para as 6 regionais de uma maneira geral. O limite inferior do intervalo de $95 \%$ de confiança para a idade dos gatos primo vacinados foi igual a 7,7 meses.

Constatou-se que uma elevada proporção de animais foram vacinados pela primeira vez na campanha de 1993, e mais, que ambas espécies estão sendo vacinadas pela primeira vez numa idade superior à provável idade média de aquisição da infecção, o que impossibilita a eliminação da raiva animal na cidade de Recife, mesmo obtendo elevados níveis de cobertura de vacinação.

Tal fato se agrava quando for considerado que um proteção efetiva só será adquirida após um reforço da vacinação anti-rábica. Uma elevada fração de suscetíveis permanecerá circulando na cidade até uma próxima campanha, quando terão oportunidade de receber uma segunda dose da vacina. Entretanto, nesta ocasião, nova quantidade de remanescentes suscetiveis surgirá. Deve se 
considerar ainda a provavelmente baixa expectativa de vida da população de cães e gatos na cidade, a julgar pela baixa média de idade (não existindo motivos para supor que a média de idade da população em geral desses animais seja diferente da média de idade daqueles que participam da campanha de vacinação, ao menos de forma acentuada). Este fato aumenta a importância do contínuo surgimento de suscetiveis através de nascimentos, pois provavelmente a maioria dos donos de animais tenderá a repor $o$ animal perdido por um novo animal. “

A persistência da raiva em Recife parece ter múltiplas origens, envolvendo alguns problemas com disponibilidade de soluções já conhecidas, outros não, por serem peculiares a uma realidade espacial e temporal da cidade e de sua população canina. Têm como ponto central a caracterização da população canina da cidade, e também da eficiência da imunização desta população contra a raiva.

A PARTIR DA AVALIAÇÃO DOS ELEMENTOS AQUI EXPOSTOS, CONSIDEROU-SE A HIPÓTESE DE QUE A PERSISTÊNCIA DA RAIVA NA CIDADE DE RECIFE ESTARIA RELACIONADA A COBERTURAS DE VACINAÇÃO IMPRÓPRIAS PARA O TAMANHO E PARA A VELOCIDADE DE RENOVAÇÃo DA POPULAÇÃo CANINA, E ElEVADA IDADE À PRIMEIRA VACINAÇÃO DOS ANIMAIS, FATORES ESTES CONDICIONADOS POR CARACTERÍSTICAS SOCIOECONÓMICAS E CULTURAIS DA POPULAÇÃO QUE CRIA ANIMAIS. 


\section{OBJETIVOS}

\subsection{Objetivos Gerais:}

Identificar, descrever e analisar os fatores relacionados à persistência da raiva na população canina da cidade de Recife, e avaliar o potencial de êxito de diferentes medidas de controle da população canina e eliminação da raiva.

\subsection{Objetivos Específicos:}

Descrever e analisar aspectos ecológicos da população canina da cidade de Recife, relacionados à eliminação da raiva canina e humana no ambiente urbano.

1. Descrever e caracterizar os casos de raiva canina da cidade de Recife, diagnosticados laboratorialmente.

2. Avaliar aspectos da eficiência do processo de imunização anti-rábica da população canina da cidade de Recife.

3. Avaliar os efeitos de diferentes taxas de imunização, perda de imunidade e mortalidade em cães, sobre a dinâmica populacional da raiva canina, considerando parâmetros específicos da população canina de Recife, incluindo imunidade, mortalidade, natalidade e idade à primeira vacinação.

4. Estimar a prevalência de indicadores em diferentes setores da cidade de Recife, associados à criação e abundância de cães, às atitudes das pessoas em relação aos cães, à frequêencia de vacinação e à restrição dos cães nessas unidades. 


\section{PROCEDIMENTOS METODOLÓGICOS}

\subsection{Estudo transversal da população canina vacinada na campanha de vacinação antj-rábica de Recife, 1995:}

A campanha de vacinação anti-rábica foi realizada em cinco dias da segunda quinzena do mês de setembro de 1995, em sextas-feiras e sábados de três semanas consecutivas.

Planejou-se obter uma amostra de 595 cães, estratificada por Região político administrativa (RPA) segundo divisão da Prefeitura da Cidade de Recife.

Realizou-se o sorteio de 35 postos, a partir de uma lista com 490 postos do $\mathrm{CCZ}$ / PCR, considerando o número médio de animais que foram vacinados em cada posto da cidade de Recife nos dois anos anteriores ao ano do estudo. Nos postos os entrevistados foram selecionados de forma sistemática, de modo a realizar um número esperado de 17 entrevistas por posto. $\mathrm{O}$ intervalo entre animais foi estimado considerando a média de animais vacinados em cada posto nos dois anos anteriores.

Ao menos um entrevistador foi designado para cada posto de vacinação. Foram aplicados questionários padronizados e previamente testados (anexo), com $o$ objetivo de colher informação relacionadas à população canina vacinada, seus proprietários, e planejamento e divulgação da campanha.

Também foram observados e registrados diversos procedimentos relacionados às atividades de campanha nos dias de vacinação. A observação iniciava com a chegada aos Distritos Sanitários (DS) às 6:30 h, de onde havia deslocamento para os postos. O encerramento ocorria com o fechamento dos postos e retorno aos DS.

A estimativa da idade à primeira vacinação em campanha foi comparada à idade à primeira vacinação de cães do inquérito domiciliar, esta última estimada a partir da curva sorológica. Também foram comparadas as pirâmides etárias dos cães vacinados em campanha e dos cães dos domicílios. Estas comparações possibilitaram uma avaliação da confiabilidade de algumas informaçð̃es obtidas no estudo. 
As estimativas foram realizadas no módulo CSAMPLE do programa EPI INFO (Center for Disease Control \& Prevention, World Health Organization, 1997), após cálculo dos pesos individuais dos registros, de maneira apropriada ao desenho da amostra.

Do ponto de vista operacional, os resultados do levantamento durante a campanha objetivaram:

a) Caracterizar a estrutura etária da população de animais que participam das campanhas anuais de vacinação anti-rábica.

b) estimar a idade à primeira vacinação contra a raiva, dos cães que participam das campanhas anuais de vacinação anti-rábica

c) Identificar fatores e procedimentos que podem comprometer o êxito da campanha. 


\subsection{Estudo transversal da população canina em domicilios da cidade de Recife, 1996:}

\subsubsection{Planejamento do estudo transversal e atividades preparatórias}

O estudo da população canina baseou-se em entrevistas durante visitas domiciliares, utilizando questionários propostos pela OMS (WHO, 1987), adaptados para a realidade de Recife e ampliados, segundo os propósitos do estudo.

Numa primeira etapa, foram planejadas as atividades de campo. Elaborou-se um manual de instrução para entrevistadores, utilizado durante o treinamento dos mesmos. A partir de maio de 1995, foram realizadas diversas reuniões e atividades, com periodicidade ao menos semanal, objetivando preparar a equipe para as atividades do projeto. Estas consistiram de estudos dirigidos - abordando tópicos sobre raiva, epidemiologia e saúde pública, treinamento para contenção de animais e colheita de sangue, processamento do material a ser estocado em laboratório, conceitos básicos sobre o programa EPI INFO, aplicação de questionários em círculos familiares e posteriormente em um estudo piloto. Toda equipe era formada por estudantes de Medicina Veterinária da UFRPE, cursando os últimos períodos ou Estágio Supervisionado obrigatório, além de Médicos Veterinários.

No mês de outubro de 1995, foi realizado um estudo piloto nos bairros de Rosarinho e Brasília Teimosa, em dois setores sorteados a partir da lista de setores censitários de Recife. Nesta ocasião, os entrevistadores realizaram as primeiras atividades em condições de campo. A partir desta experiência, foram definidos critérios para conduta diante de possíveis situações durante os trabalhos de campo.

Os dados obtidos no estudo piloto foram armazenados em banco de dados eletrônico, analisados, e com os resultados da análise, foram feitas adaptações nos questionários. Também foram desenvolvidos programas para checagem de consistência das informações (arquivos CHK do EPI INFO), um para cada questionário utilizado.

Também foram realizadas reuniões da equipe de campo com o pessoal técnico do CVA / PCR. 
O CVA / PCR foi utilizado como base para as operações, tendo fornecido transporte, equipe de vacinadores que acompanharam a equipe de trabalhos de campo, além de uma funcionária para o preparo das refeições diárias. $\mathrm{O} \mathrm{CCZ}$ também forneceu materiais para a colheita de sangue, como caixas de isopor, seringas, agulhas, além de alguns acessórios e folhetos educativos. Apenas uma parte do material foi adquirida.

Por motivos diversos, não foi possivel a divulgação antecipada da realização do estudo através dos meios disponíveis, como TV, rádios, associações comunitárias, folhetos, ou correspondência, exceto no caso de condomínios. Para estes últimos, enviou-se antecipadamente oficio pelo correio. Nos dias das entrevistas foram distribuídos folhetos educativos, e realizados contatos com as comunidades locais.

\subsubsection{Plano de amostragem:}

Em 1993 foi realizado um estudo piloto com 347 entrevistas, durante a campanha de vacinação anti-rábica no mês de setembro, cujos resultados contribuíram para a realização de algumas estimativas apresentadas a seguir. Estimou-se, para o ano de 1991, que existiam:

- 1.296.995 habitantes na cidade de Recife (IBGE, CENSO 1991).

- 344.602 domicílios na cidade (IBGE, CENSO 1991)

- 306.633 domicílios particulares ocupados na cidade $(88,98 \%$ ) (IBGE, CENSO 1991)

- aproximadamente 114.067 domicílios com cães na cidade $(37,2 \%)$.

- em média 1,81 cães por domicílio com cão na cidade.

Delimitou-se que, para as estimativas dos parâmetros relacionados à cidade de Recife com interesse para o estudo, considerando desconhecidos os valores para as características sendo investigadas $(\mathrm{P}$ máximo $=0,50$, para estimativa de proporções), o tamanho mínimo da amostra deveria ser de 384 cães, admitindo um erro $\mathrm{d}=0,05$, para um nível de confiança de $95 \%$. As fórmulas para determinação do tamanho da amostra (14 e 15) estão descritas em anexo. Entretanto, como se desejava que algumas estimativas pudessem ser úteis à operacionalização de medidas 
por parte dos serviços de saúde pública, a amostra foi estratificada por região político administrativa (RPA) da cidade, segundo critério da Prefeitura da cidade de Recife (PCR).

Como existia divergência entre o critério de classificação de RPAs da PCR e o critério de RPA utilizado pelo IBGE, foi necessário elaborar uma lista de correspondência, classificando cada setor censitário por bairro, para depois então classificar cada setor censitário por RPA da PCR.

Para obter 384 cães, admitindo uma média de 1,81 cães por domicílio com cão (dados do estudo piloto), estimou-se que seria necessário visitar 213 domicílios com cães, ou aproximadamente 573 domicílios em geral. Admitindo-se uma perda de $20 \%$ e com arredondamento, deveriam ser visitados 717 domicílios.

Entretanto, o tamanho da amostra foi aumentado para 1296 domicílios, sendo 216 para cada uma das 6 RPAs, o que permitiu compensar um possível efeito do desenho sobre a precisão das estimativas realizadas para a população canina de Recife, além de permitir que fossem realizadas estimativas para as RPAs da cidade. Neste último caso, a precisão foi menor, mas ainda assim as estimativas serão úteis para os objetivos a que o trabalho se propõe. Uma amostra de tamanho 96 permite que sejam realizadas estimativas com um erro $\mathrm{d}=0,10$, admitindo um $\mathrm{P}$ máximo, $\mathrm{e}$ com um nível de confiança de $95 \%$, sem considerar o efeito do desenho.

A amostra foi tomada em três estágios. No primeiro estágio, foram selecionados por amostragem sistemática, 6 setores censitários de cada uma das 6 RPAs definidas pela Prefeitura da Cidade de Recife (estratos), com probabilidade proporcional ao número de domicílios em cada setor. Fizeram parte da amostra 36 setores censitários (Unidade Primária de Amostragem), correspondentes a 3,32\% dos 1085 setores censitários de Recife.

No segundo estágio foi tomada uma amostra casual simples de 3 quadras em cada um dos 36 setores censitários sorteados, perfazendo um total de 108 quadras. No terceiro estágio, foram selecionados 12 domicílios em cada quadra, a partir de uma lista de domicílios, que geralmente foi elaborada no dia de cada visita, exceto quando existiam condomínios. Neste caso, as visitas no setor eram realizadas após o envio de ofícios. No total, fizeram parte da amostra 1296 domicílios. Para o sorteio, foram utilizadas tabelas de números randômicos. 
Foram excluidas das listagens as edificações com fins diferentes dos fins residenciais. Domicílios residenciais desocupados foram incluídos nas listagens para sorteio.

As estimativas foram fundamentadas nos procedimentos descritos por KALTON (1983) e manual do Centro Pan-americano de Febre Aftosa (1979), e foram realizadas no módulo CSAMPLE do programa Epi Info (Center for Disease Control \& Prevention, World Health Organization, 1997). Os pesos de cada elemento da amostra foram calculados levando em conta a probabilidade de seleção do mesmo, e o peso de cada estrato.

\subsubsection{Entrevistas e colheita de sangue dos cães}

Cada domicílio da amostra foi visitado por uma equipe de entrevistadores. Os entrevistadores usavam bata, "jeans" (para proteção de ataques dos cães), um crachá de identificação com fotografia, e geralmente um boné para proteção, já que o trabalho foi feito durante os meses do verão. Portavam pranchetas, lápis, canetas, croqui do setor e um ofício expedido pelo coordenador da pesquisa, caracterizando as atividades do projeto e solicitando o atendimento.

Cada equipe usualmente era formada por duas pessoas, que permaneciam juntas no local quando existiam cães. Do contrário uma realizava a entrevista e a outra se deslocava para o domicílio seguinte. Em alguns lugares, por questões de segurança, todo o grupo trabalhava próximo.

Realizou-se colheita de sangue para a obtenção de soro, destinado à pesquisa sorológica de anticorpos contra a raiva, em todos os cães presentes no domicílio no dia da entrevista, desde que o proprietário autorizasse, e quando era possível conter o animal com segurança. Os procedimentos para colheita de sangue, processamento e armazenamento das amostras, foram os mesmos utilizados na pesquisa em cães capturados, e estão descritos em item adiante.

Foram realizadas até duas visitas de retorno para solucionar pendências, após as quais não eram feitas novas tentativas para obtenção de informações ou colheita de material. 


\subsubsection{Informações complementares sobre o estudo transversal}

Do ponto de vista operacional, os dados obtidos a partir do estudo transversal da população canina permitiram:

a) estimar a razão habitantes : cães e a densidade canina por unidade de área.

b) descrever características da população que cria cães.

c) descrever características da população que não cria cães.

d) caracterizar a estrutura da população canina domiciliada quanto a idade, sexo, raça e características reprodutivas.

e) identificar as funções dos cães domiciliados para a população humana.

f) Estimar a taxa de renovação da população canina domiciliada, incluindo aspectos de natalidade e mortalidade.

g) Determinar o nível de restrição dos cães domiciliados.

h) Determinar o nível de dependência dos cães domiciliados.

i) Identificar a origem dos cães domiciliados.

j) Caracterizar as atitudes das pessoas em relação aos cães e em relação às medidas de controle da população canina e campanhas de vacinação, e em especial, identificar motivos de não vacinação dos cães contra a raiva e motivos para não vacinar em campanhas públicas anuais.

k) determinar o estado de vacinação contra a raiva referido pelos proprietários, e em conseqüência a cobertura de vacinação presumida.

1) determinar a presença de anticorpos protetores contra a raiva segundo a idade dos animais da amostra, e deste modo, estimar o estado de proteção efetiva contra a raiva da população canina domiciliada.

m) estimar a idade dos cães domiciliados à primeira vacinação contra a raiva.

n) Estimar a proporção de cães domiciliados vacinados, segundo o local de vacinação, ou seja, em campanha ou por outro meio;

o) Comparar as proporções oficiais de cobertura de vacinação da cidade de Recife, com as proporções de cobertura estimadas no estudo (em campanha e por qualquer meio). 
Planejava-se realizar estimativas da população de cães não restritos em áreas selecionadas da cidade, utilizando o método de recaptura "fotográfica" (BECK, 1973; WHO, 1987). Entretanto, por falta de recursos financeiros, esta meta não foi atingida.

\subsection{Estudo sorológico dos cães capturados pelo CVA/PCR, 1995-} 1996:

Entre a segunda quinzena de dezembro de 1995 e primeira quinzena de abril de 1996 foram realizadas colheitas semanais de sangue em cães provenientes de Recife, capturados e enviados ao canil do CVA/PCR. Foram definidos dois conglomerados (Silva, 1998) de dias da semana (terças e quintas feiras) que permitiriam que todos os cães capturados tivessem possibilidade de pertencer à amostra, o que levou em consideração o tempo regulamentar de permanência dos cães capturados no canil, que é de três dias. Por sorteio foram selecionados os dias de quinta feira. Nestes dias, no turno da tarde e após o período de capturas, as quais são realizadas apenas pela manhã, selecionou-se 1 cão de cada dois cães existentes em cada canil, de forma sistemática, para a colheita de sangue.

Os animais selecionados eram trazidos do canil e colocados sobre uma mesa construída em alvenaria, utilizada para os procedimentos rotineiros do canil. Um auxiliar do CVA realizava a contenção do animal, o qual era amordaçado por um membro da equipe de colheita, devidamente treinado e com indumentária apropriada. Um outro membro da equipe de colheita realizava a punção venosa, fazendo uso de seringas descartáveis de $10 \mathrm{ml}$ e agulhas $25 \times 7$ ou $25 \times 8$, também descartáveis, de acordo com o porte do animal. Para a anti-sepsia utilizaram-se chumaços de algodão embebidos com álcool a $70 \%$ iodado.

Uma vez realizada a colheita, as amostras eram mantidas no interior das seringas com tampa protetora da agulha, e eram devidamente identificadas com uma etiqueta numerada. As seringas eram acondicionadas e transportadas em caixas de isopor até a chegada no laboratório, o que se dava em no máximo 1 hora e meia após o término da colheita. 
Em fichas apropriadas anotava-se o número da amostra, além de grupo etário presumido, sexo, raça e área de captura do animal. Foram considerados os seguintes grupos etários presumidos: filhotes (até 3 meses); jovens ( 4 a 11 meses); adultos ( 1 a 7 anos) e velhos (acima de 7 anos).

Não houve colheita no periodo carnavalesco de 1996, devido à suspensão temporária das capturas.

Esta etapa da investigação permitiu estimar a proporção de indivíduos com anticorpos contra a raiva, segundo grupo etário, dentre os cães capturados nas ruas de Recife.

Deve-se ressaltar ainda que especial atenção foi dada ao treinamento da equipe de colheita, em particular quanto aos itens segurança, higiene e contenção dos animais, além de orientação para boas relaç̃̃es com o pessoal auxiliar do canil. Todo o pessoal da equipe de colheita era, além de treinado, imunizado preventivamente contra raiva.

\subsection{Exames Sorológicos}

\subsubsection{Processamento e armazenamento das amostras}

Uma vez no laboratório, todas as amostras de sangue eram processadas da seguinte maneira:

Removia-se o êmbolo da seringa, e em seguida os coágulos. O soro era então transferido para tubos de ensaio identificados, e centrifugado para remoção de resíduos de coágulos, com a finalidade de minimizar as perdas de material devido a hemólise.

Em seguida, as amostras eram fracionadas de acordo com o volume, e as alíquotas eram colocadas em tubos do tipo ependorf também identificados, os quais eram armazenados em depósitos plásticos para serem estocados em freezer a $-20{ }^{\circ} \mathrm{C}$, aproximadamente. 


\subsubsection{Transporte}

Ao final do período de colheita, as amostras foram encaminhadas ao Laboratório de diagnóstico de raiva do Centro de Controle de Zoonoses $(\mathrm{CCZ})$ do município de São Paulo / SP. Nesta etapa, as amostras congeladas foram transportadas por via aérea, no interior de caixa de isopor contendo gelo reciclável. Chegando ao laboratório, as amostras foram mantidas congeladas a $-20^{\circ} \mathrm{C}$, até a realização das provas sorológicas.

\subsubsection{Testes sorológicos}

Para pesquisa de anticorpos, utilizou-se uma técnica de soroneutralização em cultivo celular (WHO, 1996; Smith et al., 1973), denominada prova rápida de inibição de foco fluorescente, adaptada para a rotina dos laboratórios de diagnóstico de raiva do CCZ. A prova é descrita por Almeida et al. (1997).

Esta prova, juntamente com a prova de neutralização em camundongos, é recomendada pela Organização Mundial de Saúde (WHO, 1992), para a determinação da indução de anticorpos neutralizantes, dentro dos procedimentos para autorização de circulação de vacinas para uso humano.

A técnica consiste em trabalhar diluições sucessivas (em dobro) dos soros em teste, previamente inativados pelo calor (banho maria a $56{ }^{\circ} \mathrm{C}$, durante 30 minutos), às quais se adiciona um volume fixo de vírus rábico PV de título conhecido'. Em cada bateria se utilizam diluições de um soro padrão ${ }^{10}$ com título de anticorpos conhecido, medido em unidades internacionais por unidade de volume (UI / $\mathrm{ml}$ ). Após incubação das diluições de soro + vírus $\left(37^{\circ} \mathrm{C}\right.$ e $5 \%$ de $\mathrm{CO}_{2}$, durante 60 minutos), adiciona-se nas microplacas suspensão de células BHK 21 (ATCC) em meio de cultura ${ }^{11}$, incubando-se novamente as mesmas $\left(37^{\circ} \mathrm{C}\right.$ e $5 \%$ de $\mathrm{CO}_{2}$, durante

\footnotetext{
${ }^{9}$ Foram utilizadas amostras do $\mathrm{CCZ}$ dos lotes PV45/96 (1:16) e PV01/97 (1:8).

10 Instituto Pasteur de Paris (lote R 5672).

11 Minimum Essential Medium Eagle (MEM): Sigma (M1018)
} 
24 horas). Concluida a incubação, o meio líquido é removido cuidadosamente das placas, e as células remanescentes, em camadas, são fixadas com acetona a $80 \%$ gelada (15 minutos), para em seguida serem tratadas com um conjugado de anticorpos anti-vírus rábico e fluoresceína (em câmara úmida a $37^{\circ} \mathrm{C}$, durante 1 hora), preparado no Laboratório do CCZ / SP. Terminado o processamento, as placas são examinadas em microscópio de imunofluorescência.

Foram utilizados soros controle positivos e negativos.

$\mathrm{Na}$ leitura, verifica-se em que diluição do soro ocorreu inibição da formação de focos fluorescentes em aproximadamente $50 \%$ das células. Esta diluição é comparada com aquela observada no soro padrão, e por regra de três simples, estimase o título de anticorpos nos soros testados. Nas diluiçðes utilizadas, o limite inferior estabelecido para o título de anticorpos foi de $0,1 \mathrm{UI} / \mathrm{ml}$, abaixo do qual as amostras eram classificadas na categoria de título inferior a $0,1 \mathrm{U} / \mathrm{ml}$.

Para os propósitos de análise na presente investigação, títulos iguais ou superiores a $0,5 \mathrm{UI} / \mathrm{ml}$ foram classificados como "boa resposta", e para estes mesmos valores utilizou-se o termo "vacinados imunes" nas simulações com modelo matemático. Na modelagem matemática, animais com títulos inferiores a $0,5 \mathrm{UI} / \mathrm{ml}$ foram classificados como "suscetiveis. Este limiar foi adotado como indicador de eficiência da imunização. ". A escolha deste critério será justificada a seguir.

A Organização Mundial de Saúde considera que humanos expostos a risco contínuo devem receber vacinação anti-rábica de reforço quando o título de anticorpos for inferior a $0,5 \mathrm{UI} / \mathrm{ml}$ (WHO, 1992), sendo este portanto o limiar de proteção adotado.

Em diversos estudos sorológicos realizados com cães, têm sido considerados positivos, protetores ou boa resposta, para fins de classificação e análise estatística, os títulos iguais ou superiores a 0,5 UI / ml (Haddad et al., 1985; Chomel et al., 1988; Soares et al., 1992; Delgado e Cármenes, 1997; Meisner et al., 1997).

Adicionalmente, o Ofício Internacional de Epizootias passou a aceitar uma redução no período de quarentena para animais ingressando em áreas livres de raiva, desde que estes sejam vacinados e apresentem títulos de anticorpos contra raiva de ao menos 0,5 UI / ml (Meisner et al., 1997; OIE, 1998). 
No presente estudo, foram testadas 320 amostras de soro de animais domiciliados e 315 amostras de soro de cães capturados pelo CVA / PCR.

\subsection{Modelagem matemática:}

Foi elaborado um modelo de compartimentos determinístico (ANDERSON; JACKSON; MAY et al., 1981; ANDERSON, 1982; SMITH, 1985), representado adiante. As estimativas para as variáveis e constantes do modelo foram baseadas em dados do estudo da população canina de Recife e em dados da literatura.

Os resultados da pesquisa de anticorpos soro neutralizantes permitiu aferir a informação sobre o estado de vacinação dos animais, estimar a fração de suscetíveis na população e também a idade média à primeira vacinação, o que será detalhado adiante.

\subsubsection{Características e suposições do modelo}

- A população total de cães tem tamanho constante. Apenas as categorias Suscetiveis e Vacinados imunes contribuem de forma significante para $o$ crescimento populacional.

- A População canina "domiciliada" é responsável por $80 \%$ dos casos de raiva registrados, aproximadamente.

- A vacinação é anual.

- A idade média à primeira vacinação é de 10 meses.

- Não são considerados possíveis efeitos estacionais nas taxas de nascimentos.

- Não se considera a possível importância da estrutura etária da população na dinâmica populacional, ao menos de forma direta e explicita (as simulações são realizadas com variações em função apenas do tempo, e não tempo e idade).

- A classe imune origina-se apenas a partir de vacinação, não se considerando a possibilidade de desenvolvimento de imunidade naturalmente, após a exposição a amostras de vírus diferentes de vírus vacinais. Em conseqüência, considera-se 
que todos os indivíduos infectados morrem. Os soropositivos serão, portanto, denotados $v(a)$.

- Considera-se homogênea a distribuição de diferentes categorias de indivíduos na população, em relação ao tempo e ao espaço. Assim, supõem-se homogeneidade na probabilidade de contato entre indivíduos na população.

No modelo, a possibilidade de migração não foi considerada.

Utilizou-se o modelo representado na Figura 4, cujas equações diferenciais ( 1 a 5) são apresentadas a seguir. A descrição das variáveis e constantes utilizadas no modelo está apresentada na Tabela 2 adiante.

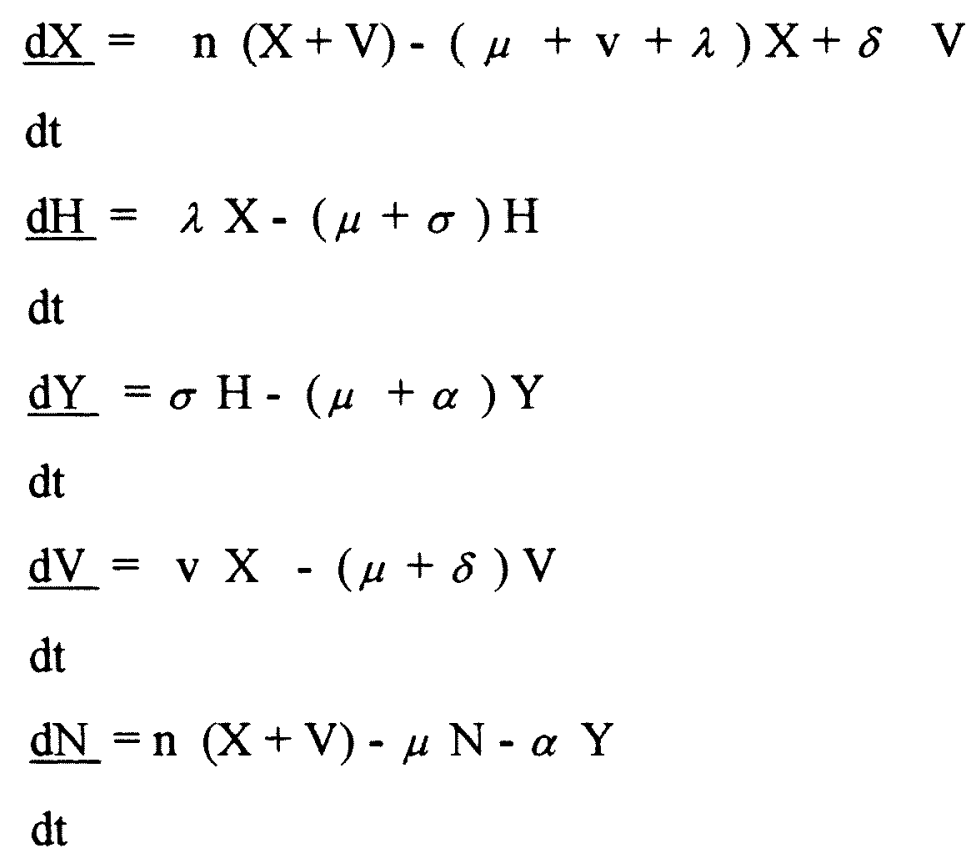

dt 
Figura 4: diagrama representativo do modelo matemático utilizado para as simulaçð̃es numéricas relacionadas à raiva na cidade de Recife / PE.

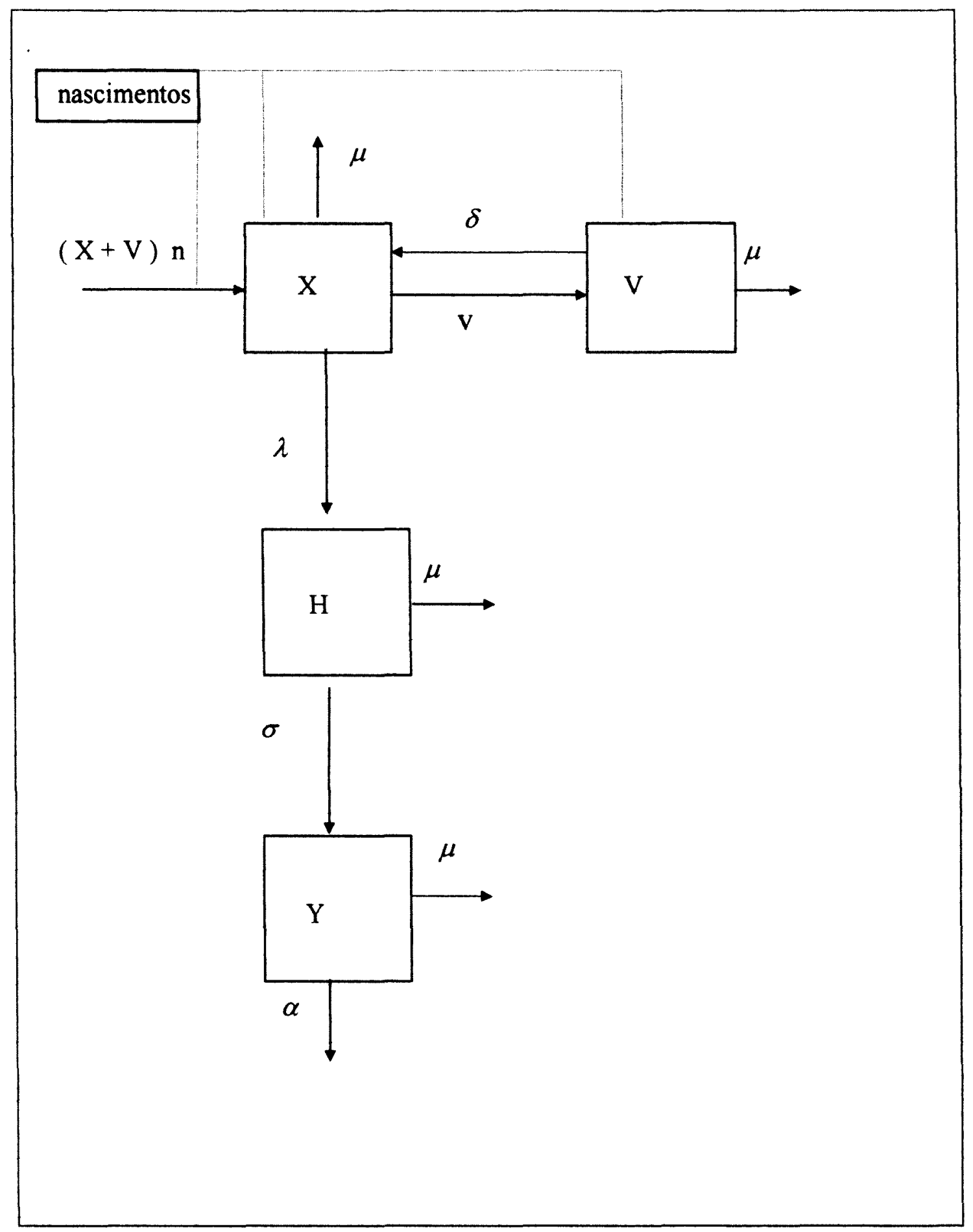


Tabela 2: variáveis, parâmetros, e variáveis de controle utilizados no modelo ${ }^{12}$ :

\begin{tabular}{|c|c|c|}
\hline Variáveis & Descrição & $\begin{array}{l}\text { Valor utilizado } \\
\text { no modelo }\end{array}$ \\
\hline $\mathrm{N}$ & $(=X+H+Y+V)$ Densidade populacional & \\
\hline $\mathrm{X}$ & Densidade de suscetíveis & \\
\hline $\mathrm{X}_{0}$ & Valor inicial da variável $X$ & 0,994 \\
\hline $\mathrm{H}$ & Densidade de infectados não infecciosos & \\
\hline $\mathrm{H}_{0}$ & Valor inicial da variável $H$ & 0,0005 \\
\hline $\mathrm{Y}$ & Densidade de infectados infecciosos ou raivosos & \\
\hline$Y_{0}$ & Valor inicial da variável $Y$ & $\mathbf{0}$ \\
\hline $\mathrm{V}$ & Densidade de Vacinados imunes & \\
\hline $\mathrm{V}_{0}$ & Valor inicial da variável $\mathbf{V}$ & 0,005 \\
\hline $\begin{array}{l}\text { Parâmetro } \\
\text { s }\end{array}$ & (Estimados para a população canina de Recife) & \\
\hline $\mathrm{n}$ & taxa média de natalidade & 0,310310 \\
\hline$\mu$ & taxa média de mortalidade & 0,310000 \\
\hline$r$ & $(=\mathbf{n}-\mu)$ taxa de crescimento intrínseco natural & 0,000310 \\
\hline$\sigma$ & $\begin{array}{l}\text { Taxa per capta de transferência do estado infectado } \\
\text { não infeccioso para o estágio infeccioso. } 1 / \sigma \text { é o } \\
\text { período médio de incubação do vírus rábico em cães }\end{array}$ & 15 \\
\hline$\alpha$ & $\begin{array}{l}\text { Mortalidade de cães atribuível à raiva. } 1 / \alpha \text { é a } \\
\text { duração média do período infeccioso da raiva em } \\
\text { cães }\end{array}$ & 45 \\
\hline$\lambda$ & $\begin{array}{l}\text { Taxa de Infecção. Estimado para recuperar um } \\
\text { número de casos De } 16 / 100.000 \text { cães. }\end{array}$ & $\mathbf{0 , 0 0 2 0 0}$ \\
\hline$\delta$ & Taxa de perda de imunidade & 3,5 \\
\hline $\mathrm{v}$ & Taxa de vacinacão & 1,2 \\
\hline Controles & (variáveis nas simulaçōes) & \\
\hline $\mathrm{v}$ & Taxa de vacinação & Variável \\
\hline$\delta$ & Taxa de perda de imunidade & Variável \\
\hline$\mu$ & taxa média de mortalidade & Variável \\
\hline
\end{tabular}

12 Tabela adaptada de SMITH (1985). 


\subsubsection{Etapas da Modelagem:}

A partir dos dados sorológicos, ajustou-se uma curva etária de soroprevalência, representada pela função

$V(a)=\left[1-\exp ^{-0,063 a}\right] 0,47$

onde $<a>$ representa a idade em meses.

O cálculo da força de vacinação foi realizado a partir da expressão

$\mathrm{v}(\mathrm{a})=\left\{\frac{\delta V(a)+\frac{d V}{d a}}{1-\mathrm{V}(\mathrm{a})}\right\}$

Nesta etapa, considerou-se que a população total é $\mathrm{X}+\mathrm{V}$, isto é, $\mathrm{X}(\mathrm{a})=1$ $\mathrm{V}$ (a), pois o número de doentes em relação à população total é muito reduzido.

O cálculo da idade média à primeira vacinação, estimada em 10 meses a partir dos dados do estudo, foi realizado a partir da expressão

$$
A,=\frac{\int_{0}^{L}[1-V(a)] d a}{\int_{0}^{L} V(a)[1-V(a)] d a} \equiv 10 \text { meses }
$$

Onde L é a expectativa de vida média dos cães da cidade de Recife, estimada em 38 meses.

Estimou-se, interativamente, o valor de $\delta$ da equação (6) que recupera o valor de $\mathrm{A}=10$ meses para a equação (8). Considerou-se que $1 / \delta$ é o tempo médio de duração da imunidade. 


\section{Elaboração do modelo}

Utilizou-se um programa escrito em Turbo Pascal para solução numérica do sistema de equações diferenciais ${ }^{13}$. Nas simulações, foram utilizados os valores descritos na Tabela 2.

Inicialmente, considerou-se que,

$$
\mathrm{N}_{\text {total }}=\text { constante } \Rightarrow n=\frac{\mu N+\alpha Y}{X+V}
$$

Pois há evidências de que existe uma relação aproximadamente constante entre $o$ número total de habitantes e o número total de cães na cidade de Recife, 0 que se constatou para os diferentes estratos da amostra, tornando bastante razoável a suposição de que a densidade da população canina é dependente da densidade da população humana, o seu crescimento acompanha o crescimento da população humana, e em curto prazo, o seu tamanho não sofre alteração significativa. Assim,

Admitindo-se, no início, $N=1, Y=0, X=X_{0}$, e $V=V_{0}$ temos,

$n=\frac{\mu}{\mathrm{X}_{0}+\mathrm{V}_{0}} \therefore \mathrm{n}=\frac{0,310}{0,994+0,005}=0,31031$

\section{Simulações}

\section{Variando $\mathbf{V}$}

Objetivando avaliar o efeito de diferentes valores da força de vacinação sobre o número de animais infectados e infectantes na população. As variações nos valores da força de vacinação podem ser resultantes de diferentes coberturas de vacinação, variação na eficiência da imunização (vacina mais imunogênica por exemplo), ou mesmo ser conseqüência de variações na idade média à primeira vacinação.

${ }^{13}$ Solver 
$\mathrm{Na}$ expressão seguinte, para cada valor de $\mathrm{v}$ calculou-se $\mathrm{o}$ valor de $\mathrm{p}$ de acordo com

$v=\mu\left[\frac{1-\exp [-(\mu+v)]}{1+\exp [-\mu]} \frac{1}{1-p}-1\right] \quad($ Massad et al, 1994)

e calculou-se $\lambda$ pós vacinação por

$$
\lambda_{0}+\mu=\frac{\lambda+\mu}{1-\mathrm{p} \frac{\mathrm{v} \exp [-(\lambda+\mu) \mathrm{a}]}{\mu+\lambda+\mathrm{v}}[1-\exp -(\mu+\lambda+\mathrm{v})]} \quad \text { (Massad et al, 1994) }
$$

Na expressão (10), $\lambda$ 。 (Força de infecção antes da vacinação) é o valor que recupera os dados originais e $\lambda$ (Força de infeç̧ão após a vacinação) é o valor utilizado em cada passo da simulação.

\section{Variando $\delta$}

Tendo como objetivo, avaliar o efeito de diferentes taxas de perda de imunidade, e em conseqüência, o efeito de diferentes períodos de duração da imunidade contra raiva, sobre o número de animais infectados e infectantes na população.

Os valores de v e $\lambda$ foram mantidos fixos, pois são independentes de $\delta$. 


\section{Variando $\mu$}

Um dos aspectos considerados na presente investigação, é de que a estrutura etária da população canina de Recife é condicionada pelas elevadas taxas de natalidade e mortalidade dos cães. Esta etapa teve como objetivo avaliar o efeito de diferentes taxas de mortalidade, e deste modo, indiretamente, o efeito de diferentes valores para a expectativa de vida média dos animais, sobre o quantidade de animais raivosos na população.

Admitiu-se que,

$$
R_{0}=1+\frac{\lambda}{\mu} \quad \text { (Anderson \& May, 1991) }
$$

e que,

$$
R_{0}=\frac{\sigma \beta}{(\sigma+\mu)(\mu+\alpha)} \quad \text { (Anderson \& May, 1982) }
$$

$\Rightarrow \frac{\sigma \beta}{(\sigma+\mu)(\mu+\alpha)}=1+\frac{\lambda}{\mu}$, onde $\lambda=\beta \bar{Y}$ (Anderson \& Mày, 1991)

Portanto,

$$
\left[\frac{\sigma \beta}{(\sigma+\mu)(\mu+\alpha)}-1\right]=\frac{\beta \overline{\mathrm{Y}}}{\mu} \quad \therefore \overline{\mathrm{Y}}=\left[\frac{\sigma \beta}{(\sigma+\mu)(\mu+\alpha)}-1\right] \frac{\mu}{\beta}
$$

Correspondendo a expressão (13) à relação entre $\mu$ (taxa de mortalidade) e o número de casos de raiva canina. 


\subsection{Análises estatísticas:}

\subsubsection{Métodos estatísticos}

A estatística descritiva dos dados obtidos foi efetuada utilizando métodos descritos por BERQUÓ; SOUZA; GOTLIEB (1981), Stevenson (1981), Kazmier (1982) e Vieira (1989), tendo incluído: apresentação tabular e gráfica, análise descritiva de variáveis qualitativas e variáveis quantitativas, testes de associação, coeficientes de correlação e análise de variância.

Os testes não paramétricos foram realizados utilizando metodologia descrita por Siegel (1975).

\subsubsection{Softwares}

Para a realização das análises estatísticas, foram utilizadas rotinas contidas em software de domínio púbico para a área de epidemiologia, o EPI INFO. Também foram montadas planilhas de cálculo para fins específicos ${ }^{14}$. Para os métodos de análise multivariada, foram utilizados dois programas ${ }^{15 \cdot 16}$. Os protocolos para as análises seguiram orientação dos manuais dos respectivos pacotes, e quando não existentes, se basearam em métodos descritos em literatura especializada.

\subsubsection{Análise multivariada}

Os procedimentos de análise de regressão logística foram realizados em software descrito por Campos-Filho e Franco (1989).

Foram construídos modelos para análise discriminante, realizadas em outro programa citado 5 .

\footnotetext{
14 Programa Excel da Microsoft.

15 Programa Multtr (Campos-Filho \& Franco, 1989)

16 Statgraphics
} 
No plano de amostragem, foram selecionadas 36 UPAs, sendo seis para cada RPA (estrato) da cidade. Para cada UPA, e para uma série de variáveis dependentes e independentes relevantes para o estudo, foram estimados valores médios, valores medianos ou proporções, conforme a natureza da variável. Numa etapa posterior, foram estimadas as medianas para as diferentes séries de valores com 36 observações cada.

Cada valor estimado para as diferentes UPAs foi codificado da seguinte maneira: 1 se o respectivo valor, da respectiva variảvel, era igual ou superior à mediana; e 0 , se estes valores eram inferiores à mediana.

Deste modo, para todas as variáveis em estudo, as diferentes UPAs foram classificadas em duas categorias, a saber, aquelas com valores abaixo da mediana, e aquelas com valores iguais ou maiores do que a mediana.

Foram montadas tabelas para testar associações entre as diferentes variáveis dependentes e independentes, uma a uma, considerando o critério de plausibilidade, e todas as variáveis que apresentaram associações estatisticamente significantes no teste $X^{2}$ ou Teste exato de Fisher $(\mathrm{P}<0,05)$, foram utilizadas no procedimento de análise multivariada.

No método de análise multivariada foram avaliadas, considerando as estimativas para as variáveis das unidades primárias de amostragem, as relações entre as variáveis abaixo relacionadas:

Tabela 3: Variáveis utilizadas como fatores de classificação (dependentes) e respectivas definições.

Fator de Classificação Definição

Cria eão:

Cão rua:

Cão Vizinhança:

Carrocinha:

Cães dependentes:

Cães restritos:

Cães vacinados:
Proporção de domicílios que criam cães

Média de cães desconhecidos soltos nas proximidades do domicílio

Média de cães de vizinhança soltos nas proximidades do domicilio

Proporção de entrevistados favoráveis à captura de cães errantes

Proporção de cães dependentes

Proporção de cães restritos

Proporção de cães vacinados contra raiva 
Tabela 4: Variáveis independentes e respectivas definições.

\begin{tabular}{ll}
\hline Variáveis independentes & Definição \\
\hline Área pcf: & Mediana da área do domicilio per capta familiar. \\
Idade 11-17: & Proporção de domicílios com pessoas entre 11 e 17 anos. \\
Instrução: & Proporção de domicilios cujos chefes concluíram o primeiro grau. \\
Lixo: & Proporção de domicilios com colheita regular de lixo. \\
Menor 5 anos: & Proporção de domicílios com pessoas entre 0 e 4 anos. \\
Proteção: & Proporção de domicilios com condições físicas de restringir os cães. \\
Renda pcf: & Mediana da Renda per capta familiar. \\
Saneamento: & Proporção de domicílios com saneamento básico. \\
Tipo domicilio: & Proporção de domicilios do tipo térreo (x tipo apartamento). \\
Agressões: & Proporção de domicilios com registro de agressão por animais. \\
Cão solto: & Média do total de cães soltos, incluindo desconhecidos e de \\
& vizinhança \\
\hline
\end{tabular}

Observação: em todo o texto restante, por questōes de simplificação, serão utilizados os nomes das variáveis em substituição à sua definiç̧̃o.

A análise discriminante fornece uma função, capaz de diferenciar tão bem quanto possível, diferentes grupos, estabelecidos segundo um critério de classificação. As variáveis foram introduzidas nos modelos segundo a probabilidade da associação entre o fator de classificação (variável dependente) e a variável independente.

Aceitou-se, como modelo final, aquele que apresentou coeficiente de correlação canônica com probabilidade inferior a $5 \%$, e classificação correta de um elevado número de unidades de observação, considerando a variável dependente em função das demais variáveis independentes. Quando o acréscimo de uma variável não modificava ou aumentava pouco o valor da correlação, ao mesmo tempo não alterando ou aumentando pouco o poder discriminatório da função, esta variável não era mantida no modelo final.

Com este procedimento, procurou-se diferenciar as áreas da cidade de Recife incluidas na amostra, quanto a fatores relevantes para o estudo. 


\subsubsection{Estudo da estrutura etária, mortalidade e natalidade da população canina}

\section{Pirâmides etárias}

Foram construídas duas pirâmides etárias da população canina de Recife, uma delas a partir de dados obtidos durante o estudo realizado na campanha de vacinação anti-rábica de Recife em 1995, e a outra, com dados do estudo transversal realizado em 1996.

Para construção das pirâmides, foram adaptados os conceitos de LAURENTI et al. (1987), para o caso dos cães da amostra de domicílios.

\section{Coeficientes de natalidade e fecundidade}

O coeficiente geral de natalidade foi obtido por dois modos, o primeiro dos quais através da fórmula abaixo, adaptada a partir de LAURENTI et al. (1987) para o caso da amostra:

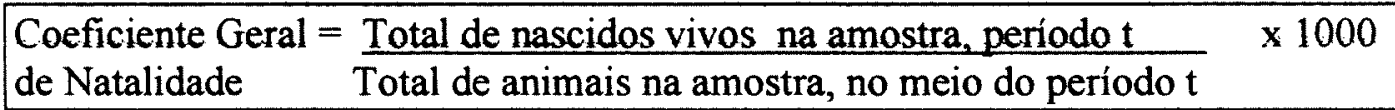

Outro coeficiente foi estimado indiretamente, a partir da combinação dos dados amostrais de: total de animais, proporção de fêmeas, proporção de fêmeas que pariram nos 12 meses anteriores à entrevista e tamanho médio das ninhadas. As estimativas de total de animais na amostra e total de filhotes na amostra daí resultantes, foram combinadas na fórmula acima descrita.

Os coeficientes de fecundidade também foram adaptados a partir de LAURENTI et al. (1987). Considerou-se idade fértil das cadelas as idades compreendidas entre 10 e 120 meses, correspondentes à menor e maior idade das fêmeas da amostra que tiveram cria. Utilizou-se a seguinte fórmula: 
Esta mesma fórmula também foi modificada para estimar os coeficientes de fecundidade segundo grupos etários.

\section{Coeficientes de mortalidade}

Os coeficientes foram calculados segundo definições de LAURENTI et al.(1987), adaptando-se os conceitos para o caso particular da amostra obtida. Portanto, os coeficientes aqui apresentados foram obtidos a partir de dados amostrais.

Para estimativa do número de cães no meio do período de estudo - ou seja, no meio do período de 12 meses que antecedeu a data das entrevistas, considerou-se que não ocorreu importante variação no total de animais dos domicílios da amostra, e que as inclusões e exclusões de animaĩs nestes domicílios, bem como na população em geral, aproximadamente se equilibraram. Assim, utilizou-se o total de cães na amostra, ou seja, 573 animais, como denominador para a estimativa do coeficiente geral de mortalidade. Para os demais coeficientes, foram utilizados os valores incluidos no total amostral, conforme cada caso.

Também é importante ressaltar que o ano, para o qual os coeficientes estão sendo calculados, não é um ano fixo, sendo na realidade um ano correspondente a um período de 12 meses que antecedem a data de cada entrevista.

Para 86 cães $(15 \%)$, a idade foi registrada como grupo etário (Fîhote, Jovem e Adulto). E para 31 animais $(5,4 \%)$, não foi feito qualquer registro de idade. No procedimento de cálculo dos coeficientes específicos por idade, o total de animais em cada faixa etária foi reajustado. O total de animais com registro de idade genérica foi distribuído entre cada faixa etária correspondente, de maneira proporcional ao total de animais com idade conhecida em cada uma destas. Em seguida, o total de animais sem registro de idade foi distribuido entre todas as faixas etárias, proporcionalmente ao total de cada uma delas.

Relativamente à mortalidade de cães, foram registrados 160 óbitos, na totalidade das entrevistas realizadas, independente do fato de serem criados cães no 
domicilio no dia da entrevista. Para os diferentes grupos etários, os óbitos foram organizados segundo grupos de causa presumida pelos entrevistados e / ou entrevistadores, levando em consideração a história de atendimento veterinário, sintomas descritos e compatibilidade dos mesmos com as principais doenças de cães conhecidas na localidade.

A mortalidade proporcional, segundo grupo etário, foi calculada pela fórmula:

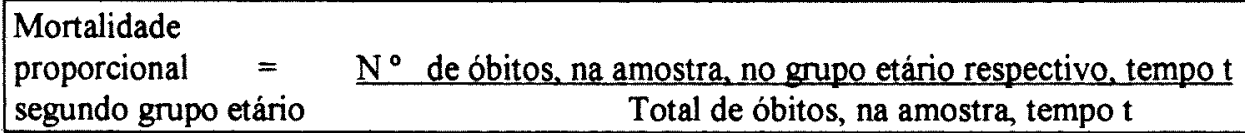

A mortalidade proporcional segundo a causa, e segundo a causa por grupos genéricos de idade, foram calculadas pelas fórmulas a seguir:

Mortalidade

Proporcional =

segundo a causa

Mortalidade Proporcional $=$ segundo a causa e por grupo etário

O coeficiente geral de mortalidade foi estimado a partir da seguinte fórmula :

Coeficiente geral de $=$ mortalidade

$N^{0}$ total de óbitos na amostra $\times 1000$

Total de animais na amostra

Os coeficientes de mortalidade segundo a causa e por grupo etário foram estimados a partir da fórmula abaixo: 
Mortalidade

Especifica $=\mathrm{N}^{\circ}$ de óbitos pela causa na amostra, na idade respectiva $\times 1000$

segundo a

Total de óbitos pela causa, no grupo etário respectiva, na amostra

causa e por

grupo etário

A partir da idéia do Indicador de Guedes (Roquayrol, 1988), elaborou-se um indicador de saúde para os cães, com grupos etários e pesos modificados. Este indicador poderá ser utilizado futuramente para comparações entre populações animais de diferentes épocas e locais.

Para calcular o valor do indicador, multiplicou-se os valores da mortalidade proporcional pelos respectivos pesos em cada grupo etário. Procedeu-se à soma dos produtos, e dividiu-se o resultado da mesma por 10. 


\subsubsection{Análise de séries temporais aplicada aos casos de raiva canina na cidade de Recife:}

A freqüência e distribuição temporal dos casos de raiva animal na cidade de Recife foram registradas a partir dos dados fornecidos pelo CVA / PCR e pelo LAPA / Ministério da Agricultura. Também nestes foram pesquisadas informações sobre as características dos animais com diagnóstico laboratorial confirmado para raiva.

O estudo da distribuição temporal dos casos de raiva canina foi realizado através do método de análise de séries temporais, empregando a abordagem clássica descrita por KAZMIER (1982). Este teve como propósito descrever o comportamento da doença em relação ao tempo, incluindo os fatores segundo o modelo $\mathrm{Y}=\mathrm{T} \times \mathrm{C} \times \mathrm{S} \times \mathrm{I}$. Trata-se de um modelo multiplicativo, onde $\mathrm{T}$ é a componente tendência secular, $\mathrm{C}$ é a componente cíclíca, $\mathrm{S}$ é a componente de estacionalidade e I a componente irregular.

No procedimento, foram identificados e segregados os fatores relacionados com o tempo que influenciam os valores observados na série (KAZMIER, 1982). O autor apresenta as seguintes definições para os componentes da anălise:

Tendência secular ( $T$ ): “ Movimento geral de longo prazo nos valores $(\mathrm{Y}) \mathrm{da}$ série temporal em um grande período de tempo."

Flutuações cíclicas (C): “ Movimentos oscilatórios, para cima e para baixo, com referência à tendência secular, que têm duração de diversos anos. "

Variações sazonais (S) ou estacionais: “ Movimentos para cima e para baixo, em relação à tendência secular, que são completados dentro de um ano e que se repetem anualmente. Tais variações são identificadas, tipicamente, com base em dados mensais ou trimestrais. "

Movimentos irregulares (I): "Variações erráticas a partir da tendência secular que não podem ser atribuídas a influências cíclicas ou estacionais. “ 
Análise de tendência:

Para a análise de tendência, utilizou-se o método dos mínimos quadrados para determinar a equação da linha de tendência, por conveniência, embora do ponto de vista estatístico os valores anuais acumulados não correspondam a uma variável aleatória nem sejam independentes (Kazmier, 1982). A equação da linha de tendência é a seguinte:

$$
\mathrm{Y}_{\mathrm{T}}=a+b \mathrm{X}
$$

Onde $a$ representa o ponto de interseção da linha de tendência com o eixo dos $\mathrm{Y}, b$ representa a declividade da reta, $\mathrm{Y}$ corresponde à variável dependente (casos de raiva) e $\mathrm{X}$ é a variável independente (tempo).

Para viabilizar as operações em diversas etapas do método, os eventuais valores iguais a zero do número mensal de casos de raiva foram igualados a 0,1 , evitando a ocorrência de erros em função de divisões por zero.

\section{Variações estacionais:}

Foram identificadas através de um número índice de estacionalidade para cada mês do ano, os quais indicam influências estacionais positivas e negativas. A média destes 12 números mensais é 100 .

Para tal, utilizou-se o método da razão à média móvel. Primeiro, determinase o quociente entre cada valor mensal e a média móvel de doze meses centrada naquele mês. A razão de um valor mensal para a média móvel pode ser representada simbolicamente por:

$$
\frac{\mathrm{Y}}{\text { Média móvel }}=\frac{\mathrm{T} \times \mathrm{C} \times \mathrm{S} \times \mathrm{I}}{\mathrm{T} \times \mathrm{C}}=\mathrm{S} \times \mathrm{I}
$$

A segunda etapa objetiva cancelar a componente irregular, isolando a componente estacional, que representa a média das razóes de cada mês, obtida após 
exclusão do valor mais alto e do valor mais baixo do mês respectivo. Tal média denomina-se média modificada.

Finalmente, as razões médias modificadas são ajustadas por um fator de correção, de modo que a soma das 12 razões mensais seja 1200.

\section{Projeções baseadas em fatores estacionais e em tendência:}

Esta etapa possibilita a estimativa de dados considerando-se os efeitos tendência e estacionalidade. Estes serão necessários às etapas posteriores de isolamento dos efeitos cíclicos e irregulares.

A equação da reta, que originalmente é estimada a partir de dados anuais, é modificada para projeções mensais. Cada elemento da equação é dividido por 12( por considerar-se que os valores de tendência não estão associados com pontos do tempo, mas com períodos de tempo). Também, o intercepto da equação modificada é reduzido por 5,5 vezes a declividade modificada, para que o ponto inicial esteja localizado no meio do primeiro mês do ano da série, e não no meio do ano (primeiro de julho) como ocorre na equação para dados anuais. A equação resultante é a seguinte:

$$
Y_{T}=\frac{a}{12}-(5,5)\left(\frac{b}{144}\right)+\frac{b}{144} X
$$

Análise das variações cíclicas e irregulares:

Apenas as componentes tendência e ciclo estão representadas nos valores anuais de uma série temporal, pois as componentes estacional e irregular são definidas como influências de curto prazo. Assim, para identificar a componente cíclica, foram divididos os valores observados pelo valor de tendência associado, como representado a seguir:

$$
\frac{\mathrm{Y}}{\mathrm{Y}_{\mathrm{T}}}=\frac{\mathrm{T} \times \mathrm{C}}{\mathrm{T}}=\mathrm{C}
$$


Multiplicou-se a razão por 100 para obter um relativo médio de ciclo igual a 100.

Para identificar a componente irregular, primeiro dividiu-se os valores mensais pelos valores projetados com base nas componentes tendência $\mathrm{e}$ estacionalidade, como representado a seguir:

$$
\frac{\mathrm{Y}}{\mathrm{T} \times \mathrm{S}}=\frac{\mathrm{T} \times \mathrm{C} \times \mathrm{S} \times \mathrm{I}}{\mathrm{T} \times \mathrm{S}}=\mathrm{C} \times \mathrm{I}
$$

Multiplicou-se a razão por 100 para se expressar uma percentagem, e a seguir, calculou-se a média móvel dos valores residuais que representam a componente cíclica e irregular, utilizando períodos de 5 meses. Tal média móvel tende a cancelar a componente irregular de curto prazo, resultando a componente cíclica.

Por último, divide-se os valores residuais pela média móvel que contem apenas a componente cíclica, obtendo-se a componente irregular, como representado a seguir:

$$
\frac{\mathrm{CxI}}{\mathrm{C}}=\mathrm{I}
$$




\section{RESULTADOS}

\subsection{Quem respondeu às entrevistas:}

$\mathrm{Na}$ maioria das vezes, as perguntas das entrevistas foram respondidas por moradores do próprio domicílio, e em parte por empregados dos mesmos (Figura 5). Entretanto, em diversas ocasiões, as informações foram fornecidas por outras pessoas que tinham conhecimento de ao menos uma parte das informações desejadas sobre o domicílio sorteado. Em tais situações, as respostas eram geralmente de natureza parcial, embora muitas vezes vizinhos e / ou parentes que residiam próximo forneciam informações com exatidão bastante razoável. Nestes casos, as perdas de informação foram apenas parciais.

Figura 5: quem foi entrevistado, em estudo da população canina de Recife / PE, 1996

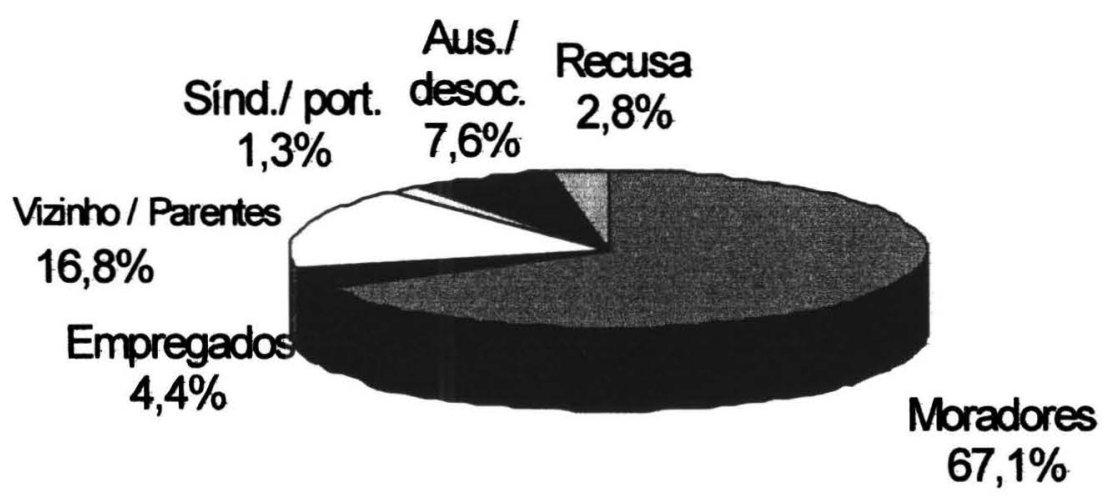

Em certas ocasiões, as entrevistas foram realizadas com síndicos e / ou porteiros dos condomínios, e as informações obtidas eram mais limitadas, como por 
exemplo sobre a existência de animais e a sua quantidade, quantidade de pessoas e faixa etária, dentre outros aspectos de conhecimento mais comum.

Quando as pessoas não estavam presentes, nem havia quem fornecesse informações, a entrevista não foi realizada, caracterizando-se perda total. Em casos de recusa, geralmente a perda era total, embora em algumas ocasiões a recusa se referia apenas a certos aspectos da entrevista e / ou trabalho de colheita.

Finalmente, em domicílios desocupados a inexistência de informações era total. O motivo de se manter nas listas os domicílios desocupados que eventualmente foram sorteados, residiu no fato de ser comum, no momento da elaboração das listas de domicílios a sortear, a existência de domicílios fechados para os quais não se dispunha de informação sobre o estado de ocupação dos mesmos (principalmente em apartamentos). Operacionalmente era inviável conferir previamente esta informação para todos os casos, motivo pelo qual se optou por um tratamento homogêneo para todos os domicilios de natureza residencial. Além do mais, existiam domicílios ocupados apenas por temporada. 


\subsection{Características diferenciais entre as Unidades Primárias de Amostragem (UPA)}

$\mathrm{Na}$ Tabela 5 adiante, estão apresentados os resultados das análise discriminatória. A matriz de correlação entre as variáveis está representada em anexo.

Tabela 5: modelos finais da análise discriminatória aplicada a diferentes variáveis dependentes, em estudo da população canina de Recife / PE, 1996.

\begin{tabular}{|c|c|c|c|c|c|c|}
\hline Vartikd & 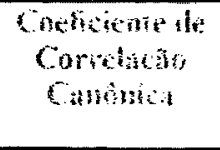 & $\begin{array}{l}\text { Frohatiindate } \\
\text { inferior a: } \\
(1+n)\end{array}$ & 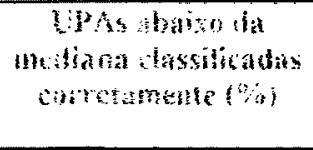 & 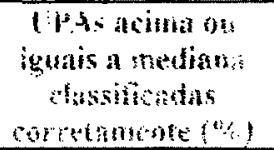 & 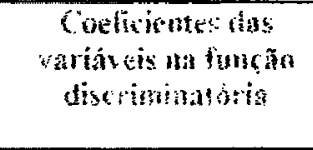 & 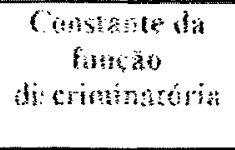 \\
\hline Cria cão & 0,47 & 0,05 & 94,12 & 63,16 & $\begin{array}{l}\text { Idadell-17 anos: } 1,36 \\
\text { Tipo domicílio: } 1,35\end{array}$ & $-1,43$ \\
\hline Cão rua & 0,64 & 0,01 & 72,22 & 77,78 & $\begin{array}{l}\text { Instrução: }-0,67 \\
\text { Lixo: } 1,76 \\
\text { Renda pcf: }-1,64\end{array}$ & 0,37 \\
\hline Cão de vizinhança & 0,85 & 0,01 & 94,44 & 94,44 & $\begin{array}{l}\text { Área pcf: } 0,92 \\
\text { Renda pcf: } 1,71 \\
\text { Saneamento: } 1,62\end{array}$ & $-2,22$ \\
\hline Carrocinha & 0,50 & 0,01 & 72,22 & 77,78 & Cão solto: 2,25 & $-1,19$ \\
\hline Cães dependentes & 0,71 & 0,01 & 88,89 & 83,33 & $\begin{array}{l}\text { Instrução: } 1,42 \\
\text { Renda pcf: } 1,50\end{array}$ & $-1,55$ \\
\hline Cães restritos & 0,72 & 0,01 & 88,24 & 84,21 & Proteção: 2,81 & $-1,41$ \\
\hline Cães vacinados & 0,45 & 0,01 & 66,67 & 77,78 & Renda pcf: 2,19 & $-1,21$ \\
\hline
\end{tabular}




\subsection{Tamanho e densidade da população canina de Recife / PE, 1996}

Na Tabela 6, estão descritas características gerais da população canina de Recife, além de variáveis de interesse para o estudo.

Tabela 6. estimativas de parâmetros da população canina, a partir de dados de uma amostra de domicílios e de dados oficiais, em estudo da população canina de Recife / PE, 1996

\begin{tabular}{|c|c|c|c|c|c|c|c|c|}
\hline 8 & Vatian & & 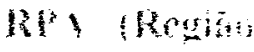 & mitho thes & intabing bis & 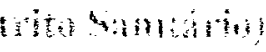 & & IfI \\
\hline & & 1 & II & III & IV & $\mathrm{V}$ & VI & \\
\hline 1 & Area da cidade de Recife (ha) & 1511 & 1479 & 13152 & 4103 & 3049 & 3893 & 27187 \\
\hline 2 & $\begin{array}{l}\text { Domicílios particulares ocupados } \\
\text { em Recife, Censo 1991 }\end{array}$ & 21624 & 45162 & 59408 & 52858 & 54110 & 73451 & 306613 \\
\hline 3 & Habitantes em Recife, Censo 1991 & 82949 & 197794 & 257805 & 222631 & 230986 & 304830 & 1296995 \\
\hline 4 & $\begin{array}{l}\text { Densidade de Habitantes / ha em } \\
\text { Recife, Censo 199l }\end{array}$ & 54,9 & 133,73 & 19,6 & 54,26 & 75,76 & 78,30 & 47,71 \\
\hline 5 & $\begin{array}{l}\text { Média de pessoas por domicílio na } \\
\text { população, Censo } 1991\end{array}$ & 3,84 & 4,38 & 4,34 & 4,21 & 4,27 & 4,15 & 4,23 \\
\hline 6 & $\begin{array}{l}\text { Total de pessoas nos domicilios da } \\
\text { amostra }\end{array}$ & 820 & 922 & 913 & 927 & 818 & 956 & 5356 \\
\hline 7 & $\begin{array}{l}\text { Média de pessoas por domicílio na } \\
\text { amostra }\end{array}$ & $\begin{array}{r}4,02 \\
(3,57 \text { a } 4,47) \\
\end{array}$ & $\begin{array}{r}4,41 \\
(3,93 \text { a } 4,88) \\
\end{array}$ & $\begin{array}{r}4,57 \\
(4,15 \text { a } 4,99) \\
\end{array}$ & $\begin{array}{r}4,52 \\
(4,11 \text { a } 4,92) \\
\end{array}$ & $\begin{array}{r}4,13 \\
(3,72 \text { a } 4,54) \\
\end{array}$ & $\begin{array}{r}4,93 \\
(4,20 \text { a } 5,65) \\
\end{array}$ & $\begin{array}{c}4,50 \\
(4,27 \text { a } 4,73) \\
\end{array}$ \\
\hline 8 & Total de cães na amostra & 73 & 93 & 93 & 109 & 90 & 114 & 572 \\
\hline 9 & Razão habitantes / cão na amostra & 11,23 & 9,91 & 9,82 & 8,50 & 9,09 & 8,39 & 9,14 \\
\hline 10 & $\begin{array}{l}\text { Média de cães por domicilio em } \\
\text { geral na amostra }\end{array}$ & $\begin{array}{r}0,33 \\
(0,21 \text { a } 0,45) \\
\end{array}$ & $\begin{array}{r}0,44 \\
(0,26 \text { a } 0,61) \\
\end{array}$ & $\begin{array}{r}0,45 \\
(0,33 \text { a } 0,57) \\
\end{array}$ & $\begin{array}{r}0,46 \\
(0,30 \text { a } 0,61) \\
\end{array}$ & $\begin{array}{r}0,40 \\
(0,15 \text { a } 0,65) \\
\end{array}$ & $\begin{array}{r}0,56 \\
(0,36 \text { a } 0,70) \\
\end{array}$ & $\begin{array}{c}0,45 \\
(0,38 \text { a } 0,52) \\
\end{array}$ \\
\hline 11 & $\begin{array}{l}\text { Proporção de domicílios com cão na } \\
\text { amostra }\end{array}$ & $\begin{array}{r}23,70 \\
(15,89 \text { a } 31,5)\end{array}$ & $\begin{array}{r}29,59 \\
(19,15 \text { a } 39,97)\end{array}$ & $\begin{array}{r}31,93 \\
(23,46 \text { a } 40,4)\end{array}$ & $\begin{array}{r}28,81 \\
(16,51 \text { a } 41,11)\end{array}$ & $\begin{array}{r}25,95 \\
(14,78 \text { a } 37,12)\end{array}$ & $\begin{array}{r}33,63 \\
(26,36 \text { a } 40,90)\end{array}$ & $\begin{array}{c}29,81 \\
(25,74 \mathrm{a} \\
33,89) \\
\end{array}$ \\
\hline
\end{tabular}




\begin{tabular}{|c|c|c|c|c|c|c|c|c|}
\hline 12 & $\begin{array}{l}\text { Média de cães por domicilio com } \\
\text { cão na amostra }\end{array}$ & 1,38 & 1,48 & 1,45 & 1,70 & 1,61 & 1,63 & 1,55 \\
\hline 13 & $\begin{array}{l}\text { Estimativa da População canina: } \\
\text { Método } 1=(2) \times(11) \times(12)\end{array}$ & 7059 & 19707 & 27564 & 25936 & 22567 & 40228 & 143061 \\
\hline 14 & $\begin{array}{l}\text { Estimativa da População canina: } \\
\text { Método } 2=(2) \times(10)\end{array}$ & 7136 & 19871 & 26734 & 24315 & 21698 & 41133 & 140886 \\
\hline 15 & $\begin{array}{l}\text { Estimativa da População canina: } \\
\text { Método } 3=(3) /(9)\end{array}$ & 7384 & 19951 & 26261 & 26178 & 25414 & 36350 & 141538 \\
\hline 16 & $\begin{array}{l}\text { Estimativa da Média da População } \\
\text { canina: média de } 13,14 \text { e } 15\end{array}$ & 7193 & 19843 & 26853 & 25476 & 23226 & 39237 & 141828 \\
\hline 17 & $\begin{array}{l}\text { Estimativa da Razão Habitantes / } \\
\text { cães: (3)/(16) }\end{array}$ & 11,53 & 9,97 & 9,60 & 8,74 & 9,95 & 7,77 & 9,14 \\
\hline 18 & $\begin{array}{l}\text { Densidade de cães / ha estimada, } \\
\text { Método } 1:(13) /(1)\end{array}$ & 4,67 & 13,32 & 2,10 & 6,32 & 7,40 & 10,33 & 5,56 \\
\hline 19 & $\begin{array}{l}\text { Densidade de cães / ha estimada, } \\
\text { Método 2: (14)/(1) }\end{array}$ & 4,72 & 13,44 & 2,03 & 5,93 & 7,12 & 10,57 & 5,18 \\
\hline 20 & $\begin{array}{l}\text { Densidade de cães / ha estimada, } \\
\text { Método 3: (15)/(1) }\end{array}$ & 4,89 & 13,49 & 2,00 & 6,38 & 8,34 & 9,34 & 5,21 \\
\hline 21 & $\begin{array}{l}\text { Estimativa da Média da Densidade } \\
\text { de cães / ha: média de } 18,19 \text { e } 20 \text {. }\end{array}$ & 4,76 & 13,24 & 2,04 & 6,21 & 7,62 & 10,08 & 5,22 \\
\hline 22 & População de gatos estimada & 8930 & 15124 & 13993 & 18915 & 16074 & 22838 & 95874 \\
\hline 23 & Razão habitantes / gatos estimada & 9,29 & 13,08 & 18,42 & 11,77 & 14,37 & 13,35 & 13,53 \\
\hline 24 & Densidade de gatos / ha estimada & 5,91 & 10,23 & 1,06 & 4,61 & 5,27 & 5,87 & 3,53 \\
\hline
\end{tabular}

* valores entre paréntesis nas colunas de RPAs correspondem aos intervalos de confiança para as estimativas; valores entre parêntesis nas colunas de Variável, correspondem ao número do item de varíável combinada nas operações aritméticas para a realização das estimativas 


\subsection{Características da população canina de Recife / PE, 1996}

Nas Tabela 7 a Tabela 12 a seguir, são apresentados os resultados da avaliação de aspectos particulares da população canina de Recife.

Tabela 7: caracterização dos cães quanto a sexo, estado reprodutivo, origem e idade de aquisição, em uma amostra de domicílios, Recife / PE, 1996

\begin{tabular}{lc}
\hline \multicolumn{1}{c}{ Variável } & Percentual \\
\hline Cães do sexo masculino & 61,5 \\
Razão Machos / Fêmeas & $1,56: 1$ \\
Machos castrados & 0,2 \\
Fêmeas ovariectomizadas & 3,0 \\
Fêmeas gestantes & 5,9 \\
Cães nascidos fora da cidade (migração) & 8,3 \\
Cães adquiridos com idade de até 3 meses & 86,0 \\
\hline
\end{tabular}

A maior parte dos animais foram originários de municípios da região metropolitana de Recife $(52,2 \%$, com predominância dos municípios de Olinda e Jaboatão dos Guararapes ), seguidos por animais de outros municípios do estado de Pernambuco $(11,5 \%)$, estados da região Nordeste $(11,4 \%)$, estados da região Sudeste $(11,4 \%)$, estados da região Sul $(4,5 \%)$, estados da região Centro Oeste $(2,3$ $\%)$, estados da região norte (2,3\%), e animais de países da América do Sul (2,3\%), neste último caso, um animal proveniente de Buenos Aires, Argentina. A fração complementar de aproximadamente $2 \%$ corresponde a animais nascidos fora da cidade, mas com origem não registrada. 
A grande maioria dos cães foram obtidos na forma de presentes, geralmente de vizinhos, parentes ou outras pessoas conhecidas (Tabela 8). Um número expressivo de pessoas retém uma ou mais crias de suas próprias cadelas. Percebe-se que aproximadamente um em cada dez cães foram comprados, e também um entre dez cães foram achados nas ruas próximo de casa ou do trabalho, sendo adotados pelas pessoas.

Tabela 8: forma de aquisição dos cães em uma amostra de domicílios de Recife / PE, 1996

\begin{tabular}{lc}
\hline \multicolumn{1}{c}{ Como o cão foi adquirido } & Percentual \\
\hline Presente & 62,2 \\
Cria da própria cadela & 16,2 \\
Comprado em lojas, canis, outras pessoas & 11,0 \\
Achada na rua ou em outros lugares & 9,1 \\
Outros & 1,5 \\
\hline & TOTAL \\
\hline
\end{tabular}

O Recifense cria cães principalmente por questões afetivas (Tabela 9). A maioria dos cães são animais de estimação e / ou companhia. A segunda principal finalidade dos cães é a proteção do domicílio. Entretanto, grande parte dos cães tem dupla função, sendo cães de estimação e de guarda. As demais finalidades como a caça, por exemplo, são muito pouco freqüentes. 
Tabela 9: finalidade dos cães em uma amostra de domicílios de Recife / PE, 1996

\begin{tabular}{lc}
\hline \multicolumn{1}{c}{ Utilidade do cão } & Percentual \\
\hline Estimação & 65,9 \\
Estimação e guarda & 20,0 \\
Guarda & 11,2 \\
Outros & 2,5 \\
Não sabe & 0,4 \\
\hline & TOTAL \\
\hline
\end{tabular}

Dos cães de Recife, 63 \% são animais sem raça definida (SRD). Dentre os cães de raça da amostra, foram registradas as seguintes raças: Poodle ( $9 \%)$, Pequinês (5\%), Fila Brasileiro (4,7\%), Pastor Alemão (3,2\%), Miniatura Pincher $(2,8 \%)$, Cocker Spaniel $(2,2 \%)$, Dobermann (1,9\%), Dogue Alemão $(1,3 \%)$ e ainda, com freqüência inferior a $1 \%$, as raças Rotweiler, Yorkshire, Akita, Dálmata, Basset, Boxer, Fox "Paulistinha", Husky Siberiano, Dachshund, Fox Terrier, Maltês, Pastor Belga, Perdigueiro, Rodhesian (Fila Indiano) e Setter Irlandês.

Apesar da maior parte dos cães de Recife serem animais aos quais são impostas restrições de movimento, verifica-se que aproximadamente $40 \%$ dos animais são animais com restrição parcial ou não restritos (Tabela 10). 
Tabela 10: categorização dos cães, quanto à restrição e dependência, em uma amostra de domicílios de Recife / PE, 1996

\begin{tabular}{lrc}
\hline CATEGORIZAÇÃO DO CÃO & Percentual \\
\hline RESTRIÇÃO & Não restrito & 7,3 \\
& Semi-restrito & 32,0 \\
& Restrito & 60,7 \\
DEPENDÊNCIA & & \\
& Não dependente & 0 \\
& Semi-dependente & 26,7 \\
& Dependente & 73,3 \\
\hline
\end{tabular}

Os animais semi-restritos são mantidos soltos parte do dia, quando se movimentam livremente pela rua. Eles são soltos por motivos diversos, em geral para defecar e urinar, ou então, no período noturno para guardarem a casa. Como parte desses domicílios não possuem portões ou muros, os cães têm livre acesso à rua.

Há finalmente, aqueles cães que a qualquer momento têm liberdade para sair de casa, que por aquiescência do dono, ou mais uma vez por impossibilidade de restrição do animal.

Todos os animais da amostra de domicílios são dependentes em algum grau de seus donos, a maioria deles totalmente dependentes, principalmente quanto à alimentação e abrigo. No entanto, quase um terço dos cães têm parte de suas necessidades satisfeitas fora do ambiente domiciliar, geralmente devido ao fato dos animais saírem com certa freqüência à rua, quando procuram por alimentos.

Uma pequena proporção dos proprietários deixa seus cães todo o tempo solto exatamente para que os mesmos possam se alimentar, uma vez que não possuem condições financeiras para satisfazer às necessidades dos seus cães. Estas pessoas fornecem abrigo e proteção aos animais, e apenas uma parte da alimentação que necessitam. 
Aproximadamente $16 \%$ dos domicílios entrevistados fornece alimentação para cães da vizinhança ou animais de rua, e outros $15 \%$ dos entrevistados mencionaram que cães da rua comem habitualmente na lixeira da casa, geralmente deixada nas calçadas. Proporção semelhante de entrevistados relataram que domicílios vizinhos fornecem alimentação para os seus cães, para cães de vizinhança ou da rua.

Com base nos resultados da avaliação dos diferentes itens dos questionários, os cães foram classificados em categorias, tomando como base as características de restrição e dependência. Os resultados estão apresentados na Tabela 11.

Tabela 11: classificação dos cães em uma amostra de domicilios de Recife / PE, 1996

\begin{tabular}{lc}
\hline Categoria & Percentual \\
\hline Cão não restrito & 7,3 \\
Cão de vizinhança & 19,4 \\
Cão familiar & 12,3 \\
Cão restrito & 61,0 \\
\hline TOTAL & 100 \\
\hline
\end{tabular}

Por fim, apresenta-se as razões entre o número de habitantes e o número de cães e gatos para as diferentes RPAs da cidade de Recife (Tabela 12).

A RPA I, constituída pelos bairros da região central da cidade, foi a que apresentou menor número de cães em relação ao número de habitantes. Em seguida vêm as RPAs II e III, situadas na zona norte da cidade de Recife, com diversos bairros em áreas de morros e córregos, alguns em áreas de desmatamento e ocupação recentes, outros situados na divisa com o município de Olinda, sendo estes bairros, com freqüência, habitados por populações de baixa renda.

O maior número de cães em relação ao número de habitantes foi encontrado nas RPAs IV, V e VI. A RPA VI, com a maior dessas razões, tem grande parte de sua população residindo no bairro de Boa Viagem, bairro de classes média e alta. 
Como informação complementar, apresenta-se também a razão entre o número de habitantes por gato, para cada RPA da cidade de Recife. Verifica-se que a população felina na RPA I, chega a ser maior do que a população canina ${ }^{17}$. $O$ número gatos é muito maior do que aquele utilizado até recentemente no serviço de controle de zoonoses, que é de 1 gato para cada 30 habitantes.

Tabela 12: razão entre o número de habitantes por cães e por gatos, segundo a região político administrativa, em uma amostra de domicílios de Recife / PE, 1996

\begin{tabular}{ccc}
\hline RPA / Distrito sanitário & Hab / cão & Hab / Gato \\
\hline I & 11,23 & 9,29 \\
II & 9,91 & 13,08 \\
III & 9,82 & 18,42 \\
IV & 8,50 & 11,77 \\
V & 9,09 & 14,37 \\
VI & 8,39 & 13,35 \\
\hline Toda a cidade de Recife & 9,14 & 13,53 \\
\hline
\end{tabular}

17 Nos últimos anos, tem se verificado um aumento substancial no tamanho da população felina vacinada nas campanhas de vacinação anti-rábica, e este fenômeno é atribuido por alguns a fatores econômicos. Em geral, os gatos consomem menos do que os cães, e requerem menor espaço e supervisão direta. Estas características se adequariam às condições de pessoas que querem ter um animal de estimação, mas não possuem renda suficiente para sustentar um consumo elevado, tão pouco para habitarem em locais mais espaçosos, nem para manterem empregados que cuidem dos animais. 


\subsection{Estrutura etária, natalidade e mortalidade na população canina de} Recife / PE, 1996

\subsubsection{Estrutura etária}

A estrutura etária de cães da cidade de Recife, está representada na Figura 6 e na Figura 7.

Figura 6: pirâmide etária de uma amostra de cães vacinados em campanha de vacinação anti-rábica, Recife / PE, 1995

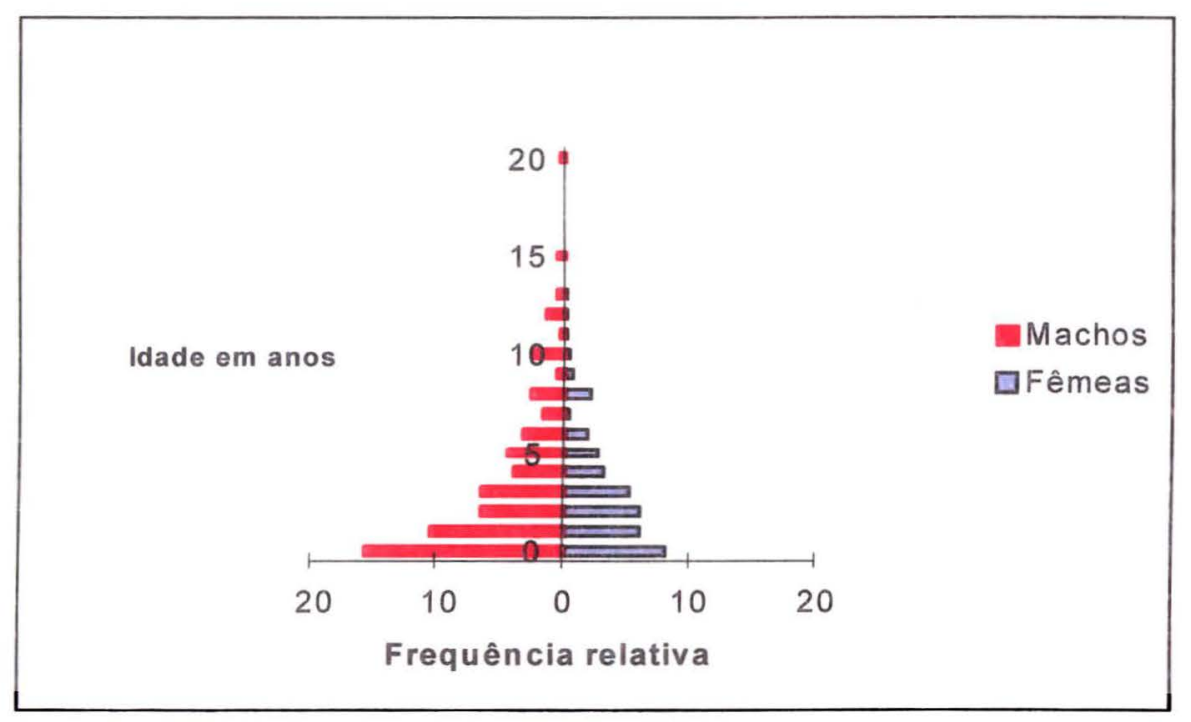

Figura 7: pirâmide etária de cães em uma amostra de domicílios de Recife / PE, 1996

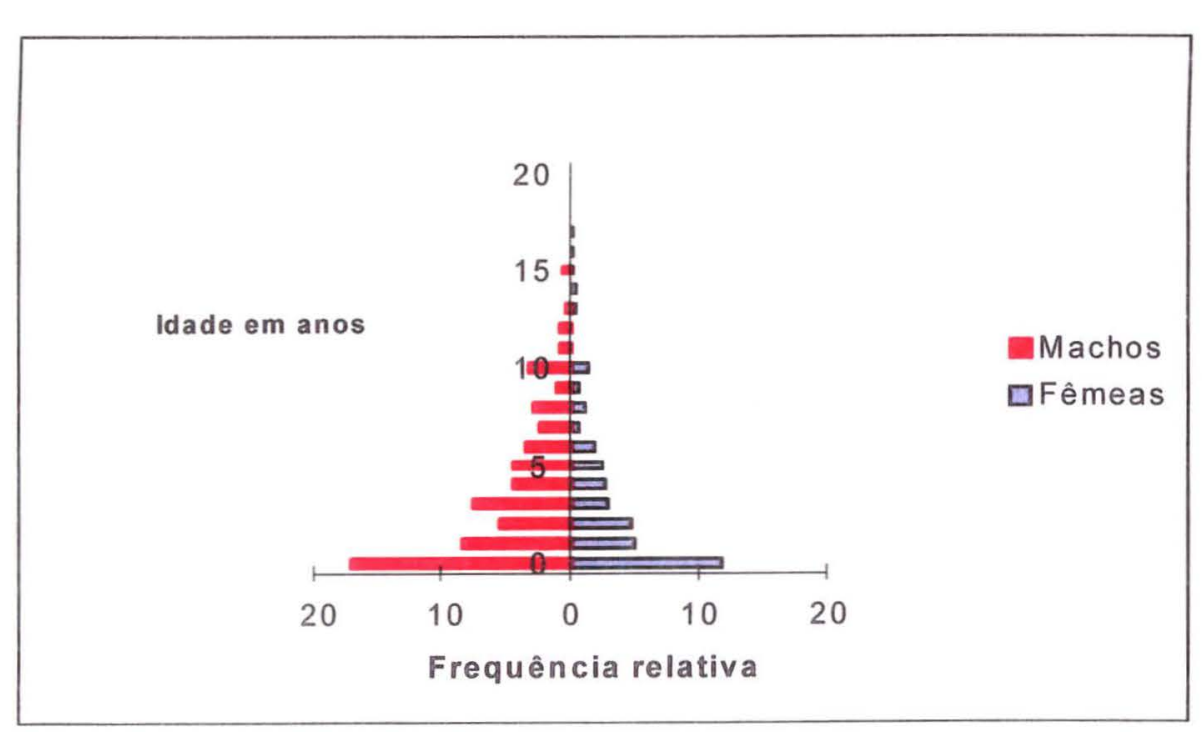


As duas pirâmides são muito semelhantes e traduzem basicamente a mesma realidade: uma população predominantemente jovem, em ambos os sexos, provavelmente resultado de elevadas taxas de mortalidade e natalidade na população canina.

A média de idade foi estimada em 39,84 meses, e a mediana foi igual a 24 meses.

\subsubsection{Natalidade}

$\mathrm{Na}$ amostra, 65,7\% das fêmeas nunca pariram durante a vida. Pariram uma vez no período de 12 meses que antecederam a entrevista $20 \%$ das fêmeas, e duas vezes $3 \%$ destas, resultando em uma média de 1,13 crias por fềmea com cria nos doze meses anteriores à entrevista. A média de filhotes por cria foi igual a 6,37, dos quais 5,73 filhotes nascidos vivos e 0,64 filhotes natimortos. A média do intervalo de tempo entre partos foi de 12 meses. A análise de variância não indicou diferenças significantes entre os tamanhos das ninhadas segundo o grupo etário dos animais.

Os coeficientes gerais de natalidade estimados variaram entre 557 e 600 por mil cães. Deve-se notar, ao comparar os dados de natalidade e mortalidade (a seguir) que a mortalidade perinatal possivelmente foi subestimada.

Os partos tenderam a apresentar uma distribuição de freqüência diferenciada segundo a época do ano (Figura 8). O gráfico inclui todos os partos com data registrada. 
Figura 8: percentual de partos em cães de uma amostra de domicílios de Recife / $\mathrm{PE}$; avaliação retrospectiva de 12 meses no primeiro trimestre de 1996.

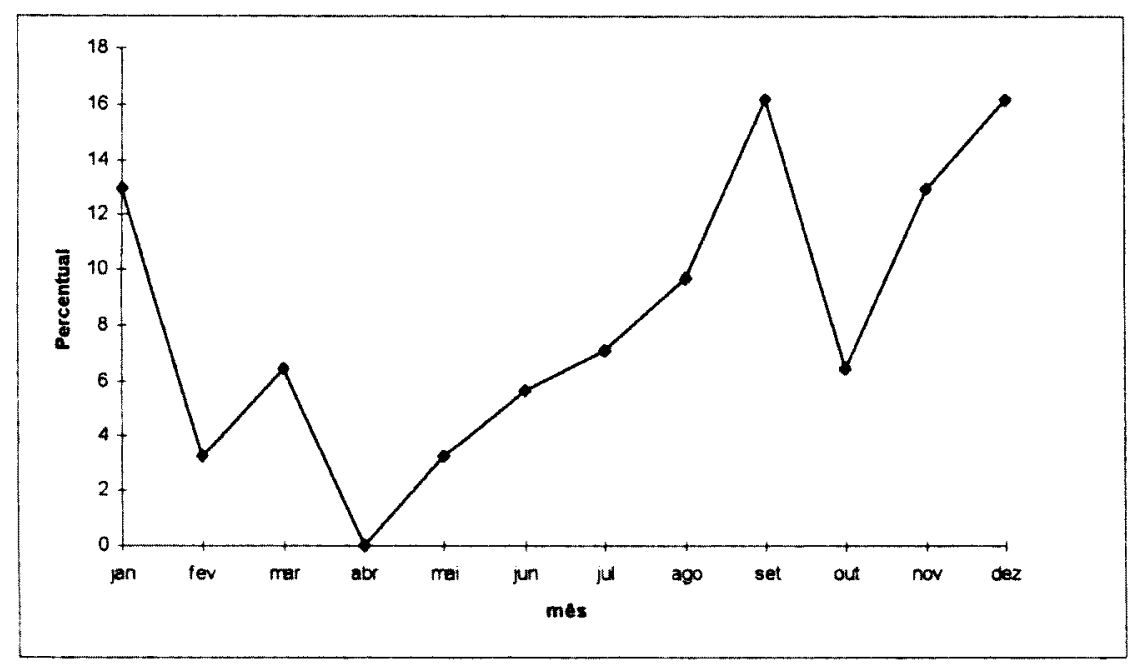

Foram estimados os seguintes valores para os coeficientes de fecundidade:

\section{coeficiente geral de fecundidade:}

2648 filhotes por 1000 cadelas com idade ente 10 e 120 meses

\section{coeficiente de fecundidade segundo a idade das fêmeas:}

10 a 35 meses: 2509 por mil cadelas.

36 a 71 meses: 2978 por mil cadelas.

72 a 120 meses: 1516 por mil cadelas. 


\subsubsection{Mortalidade}

\section{Estimativa dos coeficientes de mortalidade}

$\mathrm{Na}$ Tabela 13 são apresentados os valores para a mortalidade proporcional em cães da amostra.

Tabela 13: mortalidade proporcional em cães, segundo faixa etária, Recife / PE, 1995-6

\begin{tabular}{lc}
\hline Grupo Etário & $\%$ \\
\hline 0 a 3 meses & 33,7 \\
4 a 11 meses & 27,0 \\
1 a 3 anos & 22,8 \\
4 a 6 anos & 4,6 \\
7 a 9 anos & 4,6 \\
10 a 12 anos & 2,7 \\
13 anos ou mais & 4,6 \\
\hline
\end{tabular}

A curva de mortalidade proporcional segunda a idade, para os cães da amostra, está representada na Figura 9. 
Figura 9: curva de mortalidade proporcional para cães de Recife / PE, 1995-6

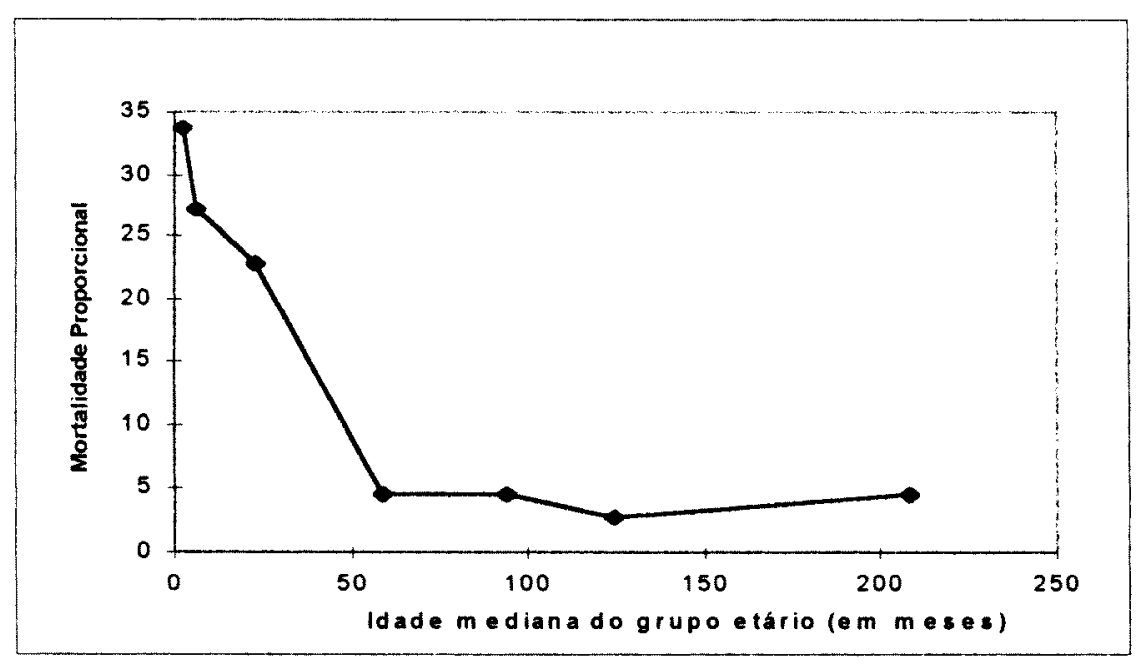

Adaptando-se o conceito e interpretação de curvas de mortalidade proporcional apresentados por Roquayrol (1988), para a situação de uma população canina, este tipo de curva seria classificado como sendo do tipo II, caracterizando um nível de saúde baixo. Esta curva, assemelha-se a um 'Jota' invertido, e nela há predomínio de mortes em animais novos, cujas causas presumidas são apresentadas na Tabela 14 e na Tabela 15.

Em filhotes com 1 a 3 meses, a principal causa presumida de mortalidade são as gastroenterites de origem infecciosa e / ou parasitária, correspondendo a $29 \%$ do total ou $71 \%$ das mortes com causa registrada. O mesmo ocorre com animais jovens, cuja idade varia de 4 a 11 meses, onde esta corresponde a $40 \%$ ou $53 \%$, respectivamente. Neste grupo, os envenenamentos são a segunda principal causa de morte ( $19 \%$ ou $25 \%$, respectivamente), vindo em seguida os atropelamentos (10\% ou $12,5 \%$, respectivamente). As duas principais causas de morte relatadas em Adultos (a partir de 1 ano de idade) são os envenenamentos (16\% ou $22 \%$, respectivamente) e os atropelamentos ( $15 \%$ ou $19,5 \%$, respectivamente). 
Tabela 14: Mortalidade Proporcional (\%) em cães, segundo a causa presumida, e segundo a causa presumida por grupo etário. Recife / PE 1995-6.

\begin{tabular}{|c|c|c|c|c|}
\hline Causa presumida & Filhotes & Jovens & Adultos & Todas \\
\hline Gastroenterites Infecciosas / Parasitárias & 29 & 40 & 7 & 24,4 \\
\hline Envenenamento & 2 & 19 & 16 & 12,5 \\
\hline Atropelamento & - & 10 & 15 & 8,0 \\
\hline Tumor Venéreo Transmissível & - & - & 3 & 1,3 \\
\hline Outras causas & 9 & 7 & 34 & 18,8 \\
\hline \multirow[t]{2}{*}{ Causas não registradas/identificadas } & 60 & 24 & 25 & 35,0 \\
\hline & & & Total $=$ & 100 \\
\hline
\end{tabular}

Tabela 15: Coeficiente Geral de mortalidade e coeficientes específicos por causa presumida, segundo faixa etária, em cães, Recife / PE 1995-6. (x 1000 cães)

\begin{tabular}{lcccc}
\hline Causa presumida & Filhotes & Jovens & Adultos & Todas \\
\hline Gastroenterites Infecciosas / Parasitárias & 198 & 177 & 10 & 68 \\
Envenenamento & 12 & 83 & 25 & 35 \\
Atropelamento & 0 & 42 & 23 & 23 \\
Tumor Venéreo Transmissível & 0 & 0 & 5 & 3,5 \\
Outras causas & 49 & 31 & 53 & 52 \\
Causas não registradas/identificadas & 383 & 104 & 38 & 98 \\
\hline Coeficiente geral de mortalidade $=$ & & & & 279 \\
\hline
\end{tabular}

Os coeficientes de mortalidade específicos por idade estão representados na Figura 10. Observa-se uma altíssima mortalidade em cães com idade de até um ano, após a qual, a mortalidade permanece mais baixa e relativamente constante, voltando a se elevar no grupo etário de 13 a 17 anos. 
Figura 10: coeficiente de mortalidade em cães de Recife / PE, 1995-6. (x 1000)

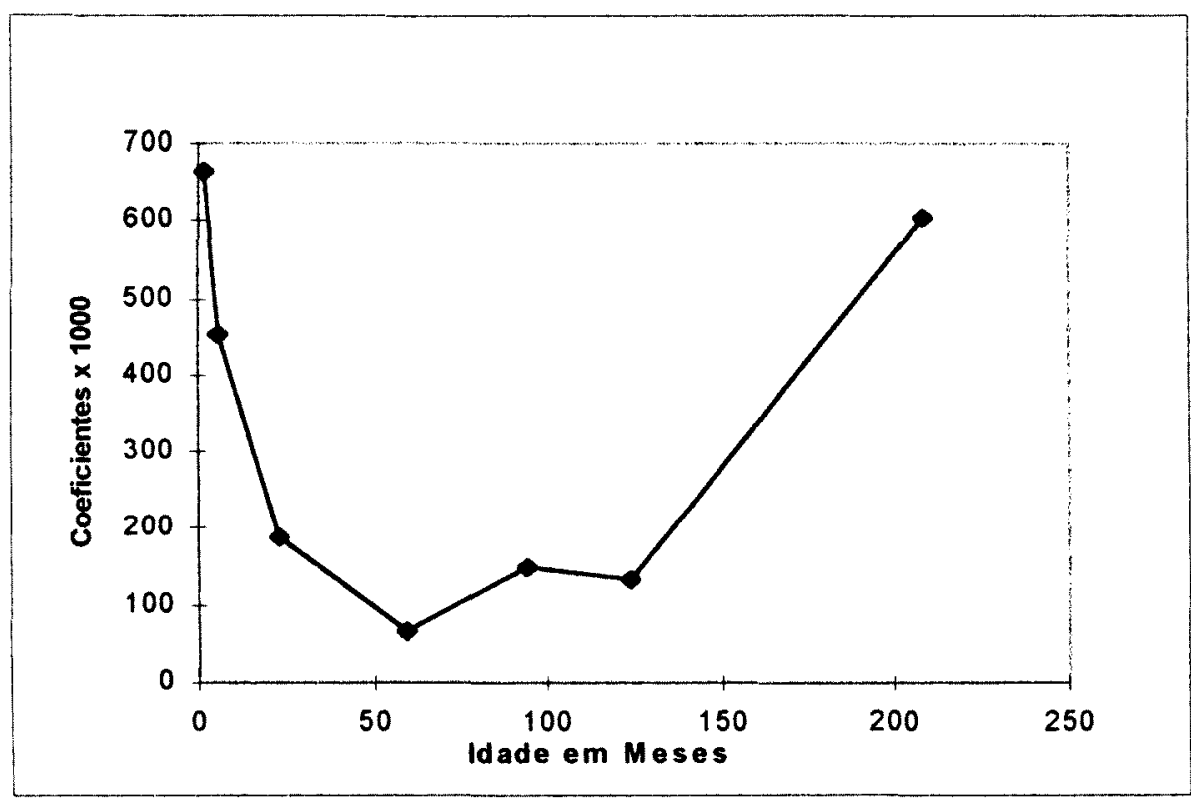

O valor do indicador de saúde para os cães de Recife, proposto no presente trabalho, assim como os pesos utilizados, estão representados numa tabela em anexo. Poderão ser úteis para efeitos de comparações entre diferentes populações e entre diferentes épocas.

\subsection{Caracterização dos casos de raiva canina em Recife, PE}

Entre os anos de 1993 e 1997, foram diagnosticados laboratorialmente 109 casos de raiva animal na cidade de Recife. Os cães representaram 98 destes casos $(89 \%)$, e os demais casos ocorreram nos seguintes animais: 8 gatos $(7,3 \%), 2$ bovinos, 1 sagüim (Callithrix sp.) e um caso em quati (Nasua nasua) do Horto Florestal no Bairro de Dois Irmãos.

A distribuição dos casos de raiva canina na cidade de Recife entre 1993 e 1997, segundo o bairro e RPA da cidade, está descrita na Tabela 16. 
Tabela 16: casos de raiva canina na cidade de Recife / PE, segundo bairro e RPA, entre os anos de 1993 e 1997.

\begin{tabular}{|c|c|c|c|c|c|c|c|c|}
\hline \multirow[b]{2}{*}{ RPA } & \multirow[b]{2}{*}{ Bairro } & \multicolumn{5}{|c|}{ Ano } & \multirow[b]{2}{*}{ Total } & \multirow[b]{2}{*}{ Percentual } \\
\hline & & 93 & 94 & 95 & 96 & 97 & & \\
\hline 1 & BOA VISTA & 1 & 0 & 1 & 0 & 0 & 2 & 2,04 \\
\hline 1 & SANTO AMARO & 1 & 3 & 2 & 0 & 1 & 7 & 7,14 \\
\hline 1 & SÃO JOSÉ & 0 & 0 & 0 & 0 & 2 & 2 & 2,04 \\
\hline 2 & ÁGUA FRIA & 0 & 0 & 0 & 1 & 1 & 2 & 2,04 \\
\hline 2 & BEBERIBE & 0 & 0 & 0 & 0 & 1 & 1 & 1,02 \\
\hline 2 & CAJUEIRO & 0 & 1 & 0 & 0 & 0 & 1 & 1,02 \\
\hline 2 & CAMPO GRANDE & 0 & 1 & 1 & 0 & 0 & 2 & 2,04 \\
\hline 2 & DOIS UNIDOS & 0 & 0 & 0 & 0 & 1 & 1 & 1,02 \\
\hline 2 & FUNDÃO & 0 & 0 & 0 & 0 & 1 & 1 & 1,02 \\
\hline 2 & HIPÓDROMO & 0 & 1 & 0 & 0 & 0 & 1 & 1,02 \\
\hline 2 & LINHA DO TIRO & 0 & 0 & 1 & 0 & 0 & 1 & 1,02 \\
\hline 3 & CASA AMARELA & 0 & 0 & 1 & 1 & 1 & 3 & 3,06 \\
\hline \multirow[t]{2}{*}{3} & CÓRREGO DO & & & & & & & \\
\hline & JENIPAPO & 0 & 1 & 0 & 0 & 0 & 1 & 1,02 \\
\hline 3 & DOIS IRMÃOS & 0 & 0 & 0 & 3 & 0 & 3 & 3,06 \\
\hline 3 & GUABIRABA & 0 & 0 & 1 & 2 & 5 & 8 & 8,16 \\
\hline 3 & MACAXEIRA & 0 & 0 & 1 & 1 & 3 & 5 & 5,10 \\
\hline \multirow[t]{2}{*}{3} & NOVA & & & & & & & \\
\hline & DESCOBERTA & 0 & 1 & 0 & 0 & 1 & 2 & 2,04 \\
\hline \multirow[t]{2}{*}{3} & POCO DA & & & & & & & \\
\hline & PANELA & 0 & 0 & 0 & 0 & 1 & 1 & 1,02 \\
\hline 3 & VASCO DA GAMA & 0 & 0 & 0 & 1 & 1 & 2 & 2,04 \\
\hline 4 & CAXANGÁ & 2 & 0 & 0 & 0 & 5 & 7 & 7,14 \\
\hline \multirow[t]{2}{*}{4} & CIDADE & & & & & & & \\
\hline & UNIVERSITÁRIA & 0 & 0 & 1 & 0 & 1 & 2 & 2,04 \\
\hline 4 & IPUTINGA & 0 & 2 & 0 & 1 & 1 & 4 & 4,08 \\
\hline 4 & PRADO & 0 & 0 & 1 & 0 & 0 & 1 & 1,02 \\
\hline 4 & TORRE & 2 & 0 & 2 & 0 & 2 & 6 & 6,12 \\
\hline 4 & TORRÕES & 0 & 0 & 1 & 0 & 1 & 2 & 2,04 \\
\hline 4 & VÁRZEA & 1 & 0 & 1 & 1 & 2 & 5 & 5,10 \\
\hline 4 & ZUMBI & 0 & 0 & 0 & 1 & 0 & 1 & 1,02 \\
\hline 5 & MANGUEIRA & 0 & 1 & 0 & 0 & 0 & 1 & 1,02 \\
\hline 5 & TEJIPIÓ & 0 & 0 & 0 & 1 & 0 & 1 & 1,02 \\
\hline 6 & BOA VIAGEM & 0 & 0 & 0 & 2 & 3 & 5 & 5,10 \\
\hline 6 & IMBIRIBEIRA & 0 & 1 & 1 & 0 & 12 & 14 & 14,29 \\
\hline 6 & JORDÃO & 0 & 0 & 0 & 0 & 1 & 1 & 1,02 \\
\hline \multirow[t]{2}{*}{6} & PINA & 0 & 1 & 0 & 1 & 0 & 2 & 2,04 \\
\hline & Totais & 7 & 13 & 15 & 16 & 47 & 98 & 100 \\
\hline
\end{tabular}


Observa-se que a doença está presente em toda a cidade (ver figura 2, apresentada em seção anterior), com freqüência crescente ao longo dos anos. Entre os anos de 1996 e 1997, ocorreu um aumento importante no número de casos diagnosticados em todas as RPAs (Tabela 17), exceto na RPA 5, que tem apresentado reduzido número de casos no periodo de 5 anos apresentado. Não se pode entretanto atestar uma situação de baixa freqüência de casos de raiva na RPA 5 , devido à provável subnotificação.

Tabela 17: total de casos de raiva canina na cidade de Recife / PE, segundo a RPA, entre os anos de 1993 e 1997.

\begin{tabular}{llllllll}
\hline & \multicolumn{7}{c}{ Ano } \\
\cline { 2 - 5 } & 1993 & 1994 & 1995 & 1996 & 1997 & Total & Percentual \\
\hline 1 (Centro) & 2 & 3 & 3 & 0 & 3 & 11 & 11,22 \\
2 (Norte) & 0 & 3 & 2 & 1 & 4 & 10 & 10,20 \\
3 (Noroeste) & 0 & 2 & 3 & 8 & 12 & 25 & 25,51 \\
4 (Oeste) & 5 & 2 & 6 & 3 & 12 & 28 & 28,58 \\
5 (Sudoeste) & 0 & 1 & 0 & 1 & 0 & 2 & 2,04 \\
6 (Sul) & 0 & 2 & 1 & 3 & 16 & 22 & 22,45 \\
\hline Total & 7 & 13 & 15 & 16 & 47 & 98 & 100 \\
\hline
\end{tabular}

A situação dos cães em relação a domicílio de referência, está indicada na Tabela 18. A situação de restrição dos cães raivosos não foi incluída no presente trabalho pelas seguintes razões: (1) um elevado número de fichas do CVA / PCR não continha o registro desta variável; (2) durante o período citado, ocorreu mudança de modelo de fichas para inquérito epidemiológico, e os campos relacionados a esta variável poderiam ser interpretados de formas diferentes; (3) existe ambigüidade nos termos utilizados para caracterizar a situação de domiciliação dos animais e a situação de restrição. Entretanto, a maior parte dos animais com dados registrados 
em fichas, aparentemente tinham acesso ao ambiente extra-domiciliar, ao menos durante parte do dia.

O termo "domicílio de referência" é aqui utilizado para caracterizar o cão com dono reconhecido, podendo este animal ter acesso às ruas em diferentes graus. O cão com domicílio de referência é um animal com alguma dependência, e com restrição variável.

Tabela 18: situação de domiciliação dos cães com diagnóstico laboratorial de raiva, entre os anos de 1993 e 1997, Recife / PE.

\begin{tabular}{|c|c|c|}
\hline Situação do cão raivoso & Total & Percentual \\
\hline Com domicílio de Referência, há mais de 2 meses no local & 75 & 76,5 \\
\hline Com domicílio de Referência, há menos de 2 meses no local & 5 & 5,1 \\
\hline Cão errante (dono e / ou local de habitação desconhecido) & 7 & 7,2 \\
\hline Situação não registrada no inquérito & 11 & 11,2 \\
\hline Total & 93 & 100 \\
\hline
\end{tabular}

Dos cães com diagnóstico de raiva, $29(29,6 \%)$ eram vacinados contra raiva, $40(40,8 \%)$ não eram vacinados contra raiva, e os outros 29 animais $(29,6 \%)$ tinham situação de vacinação desconhecida, quer pelos donos ou pela falta de registro na ficha do inquérito epidemiológico.

Apresentam-se na Tabela 19 as idades dos cães com diagnóstico de raiva, e a situação de vacinação dos mesmos. Nesta tabela estão incluídos apenas animais com idade registrada em ficha, e nas colunas de situação de vacinação, estão incluídos apenas os totais conhecidos para os respectivos animais com idade também conhecida. Portanto, não há perfeita coincidência entre os totais por idade e por situação de vacinação. Mais uma vez, a inexistência de registro de idade pode ser explicada pelo desconhecimento dos proprietários ou pela falta de registro na ficha do inquérito epidemiológico. 
Tabela 19: casos de raiva diagnosticados laboratorialmente na cidade de Recife / PE, entre 1993 e 1997, segundo o grupo etário e situação de vacinação contra raiva.

\begin{tabular}{lcccccc}
\hline & & & \multicolumn{2}{c}{ Vacinados } & \multicolumn{2}{c}{ Não vacinados } \\
\cline { 5 - 8 } Idade & Total & $\%$ & $\mathrm{n}$ & $\%$ & $\mathrm{n}$ & $\%$ \\
\hline 1 a 4 meses & 12 & 17,65 & $3(11,11)$ & 27,27 & $8(21,05)$ & 72,73 \\
5 a 11 meses & 8 & 11,76 & $0(0)$ & 0 & $8(21,05)$ & 100 \\
1 ano & 8 & 11,76 & $2(7,41)$ & 28,57 & $5(13,16)$ & 71,43 \\
2 anos & 10 & 14,71 & $5(18,52)$ & 55,56 & $4(10,53)$ & 44,44 \\
3 anos & 13 & 19,12 & $5(18,52)$ & 45,45 & $6(15,79)$ & 54,55 \\
4 a 7 anos & 10 & 14,71 & $6(22,22)$ & 60,00 & $4(10,53)$ & 40,00 \\
8 a 10 anos & 9 & 10,29 & $6(22,22)$ & 66,67 & $3(7,89)$ & 33,33 \\
\hline Total & 70 & 100 & $27(100)$ & 41,54 & $38(100)$ & 58,46 \\
\hline
\end{tabular}

* os valores entre parêntesis correspondem aos percentuais dentro da categoria (coluna). A soma dos totais Vacinados e Não vacinados não correspondem ao Total pois a situação de vacinação não era conhecida para todos os animais.

Os casos de raiva estão ocorrendo em animais de todas as idades, em freqüências não muito diferenciadas. Dentre os cães raivosos com idade e situação de vacinação conhecida, $58 \%$ eram cães não vacinados, restando ainda uma importante fração de animais raivosos com histórico de vacinação.

Os dados disponíveis não permitiram a realização de uma avaliação satisfatória da situação de vacinação dos cães com diagnóstico de raiva, relativamente à comprovação da vacinação, número de doses e tipo de vacina utilizada, local de vacinação, e quanto ao tempo transcorrido entre a data da última vacinação e o diagnóstico da doença, para que fossem identificados possíveis casos de tempo insuficiente para o estabelecimento da imunidade, vacinação em dia, e vacinação vencida (há mais de 12 meses).

Presume-se que os registros na ficha de inquérito epidemiológico, quando indicam estado de vacinado contra raiva, identificam corretamente a situação de vacinação vigente, ao menos na maioria dos casos. 


\subsection{Análise temporal dos casos de raiva canina de Recife}

$\mathrm{Na}$ Figura 11 estão representados os casos de raiva canina, diagnosticados laboratorialmente, entre os anos de 1974 e 1997.

Figura 11: número de casos de raiva canina diagnosticados laboratorialmente na cidade de Recife entre os anos de 1974 e 1997.

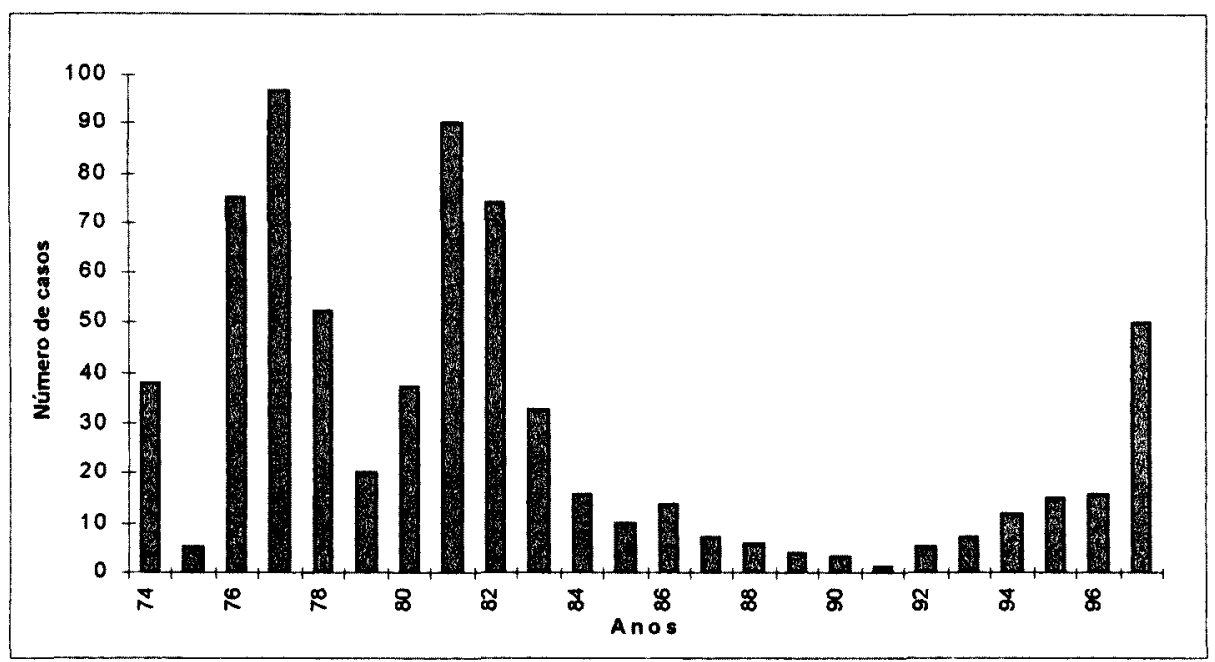

Fonte dos dados: C.V.A.PCR e LAPA

Para uma visualização mais detalhada da série histórica analisada no estudo de séries temporais, os casos diagnosticados entre os anos de 1987 e 1997 foram representados em figura já apresentada no tópico "Caracterização do problema da raiva na cidade de Recife".

\subsubsection{Análise de tendência:}

$\mathrm{Na}$ Figura 12 estão representados os números de casos de raiva canina notificados e os valores esperados. Os valores mensais de tendência foram multiplicados pelos respectivos índices estacionais, resultando em valores esperados baseados em dados de tendência e estacionalidade. Observa-se uma tendência de 
aumento no número de casos de raiva. No ano de 1997 entretanto, o número de casos observados indica um aumento repentino e acentuado do número de casos de raiva canina, o que pode modificar de maneira acentuada o comportamento da raiva nos meses seguintes à série histórica.

Figura 12: casos de raiva canina na cidade de Recife, entre os anos de 1987 e 1997; observados e esperados (baseado em dados de tendência e estacionalidade.

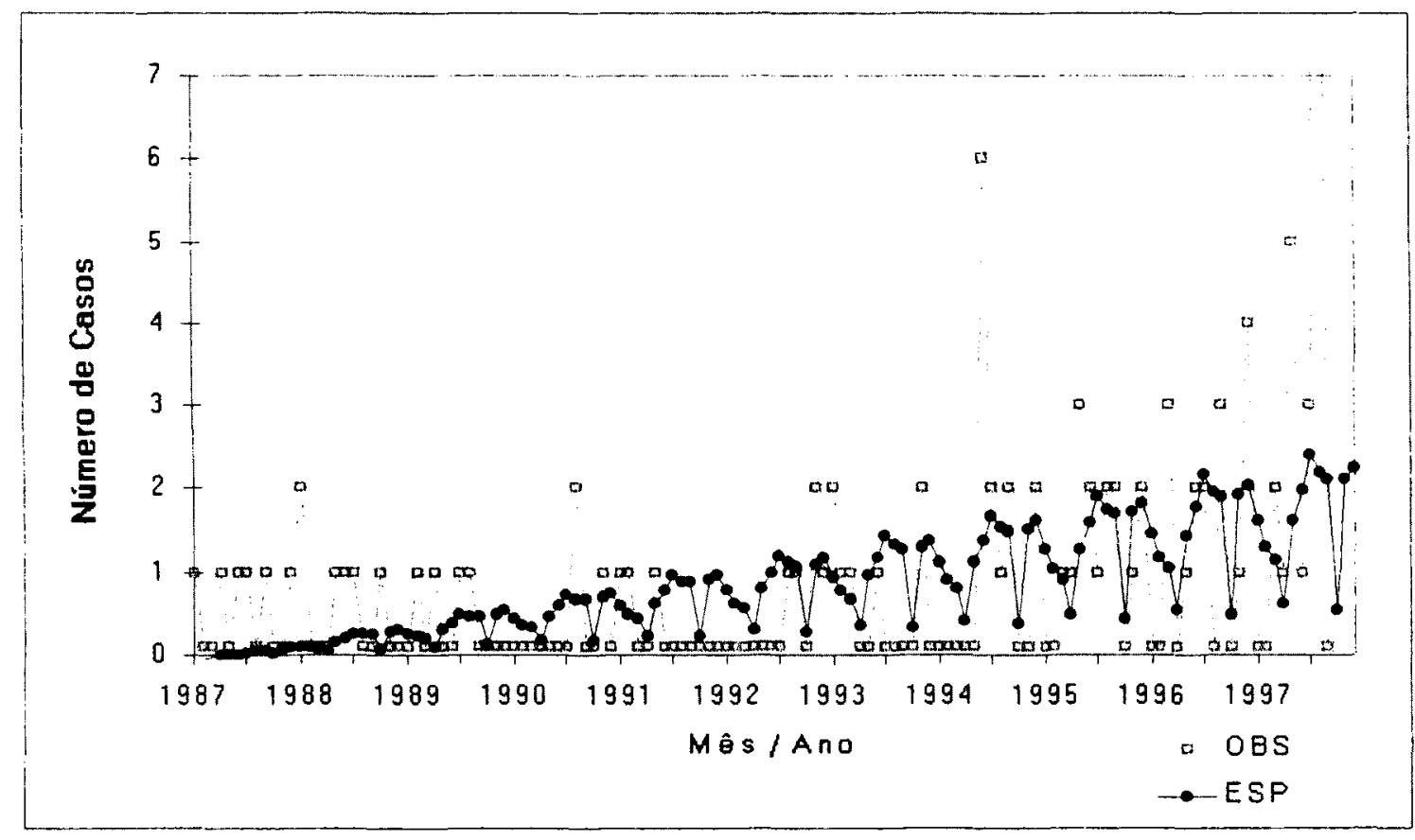

\subsubsection{Indices estacionais:}

Na Figura 13 estão representados os índices estacionais para os casos de raiva canina notificados na cidade de Recife entre os anos de 1987 e 1997. Estes indices variam ciclicamente, e os picos nos valores dos mesmos ocorrem no meio e no final do ano, nos meses de julho e dezembro, respectivamente. Ambos os picos são antecedidos por crescimento gradual dos índices, e são sucedidos por decréscimo gradual dos mesmos. Os menores índices são observados nos meses de abril e outubro, este último, o menor de todos, ocorrendo no mês seguinte ao mês de setembro, quando ocorrem as campanhas anuais de vacinação anti-rábica. 
Figura 13: índices estacionais para raiva canina em Recife / PE, entre os anos de 1987 e 1997.

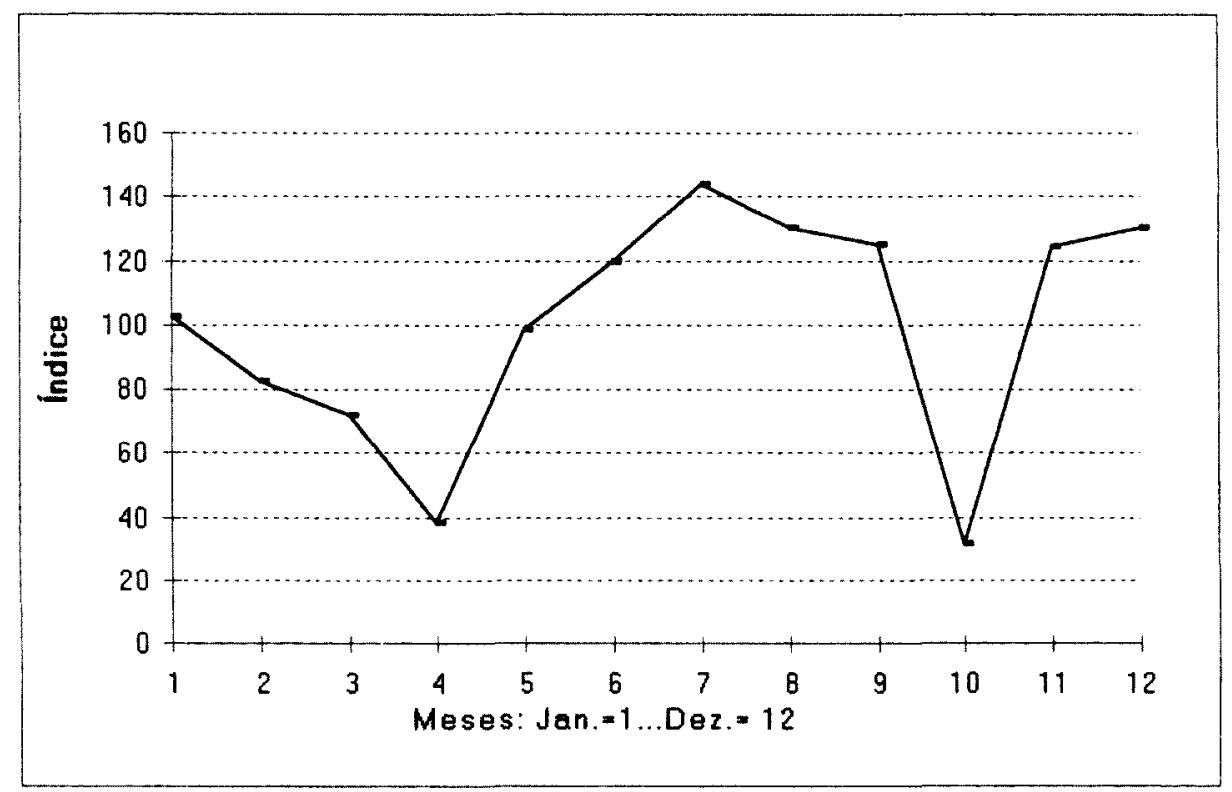

Em busca de uma possível explicação para o comportamento estacional da raiva canina em Recife, foram tabulados os dados relativos às datas da última cria das cadelas pertencentes à amostra do estudo transversal, datas essas relatadas pelos proprietários dos animais. O percentual de crias segundo o mês do ano, juntamente com os índices estacionais de casos de raiva canina, estão representados na Figura 14. 
Figura 14: índices estacionais para casos de raiva canina em Recife / PE (1987 a 1997) e partos em cadelas (\%)

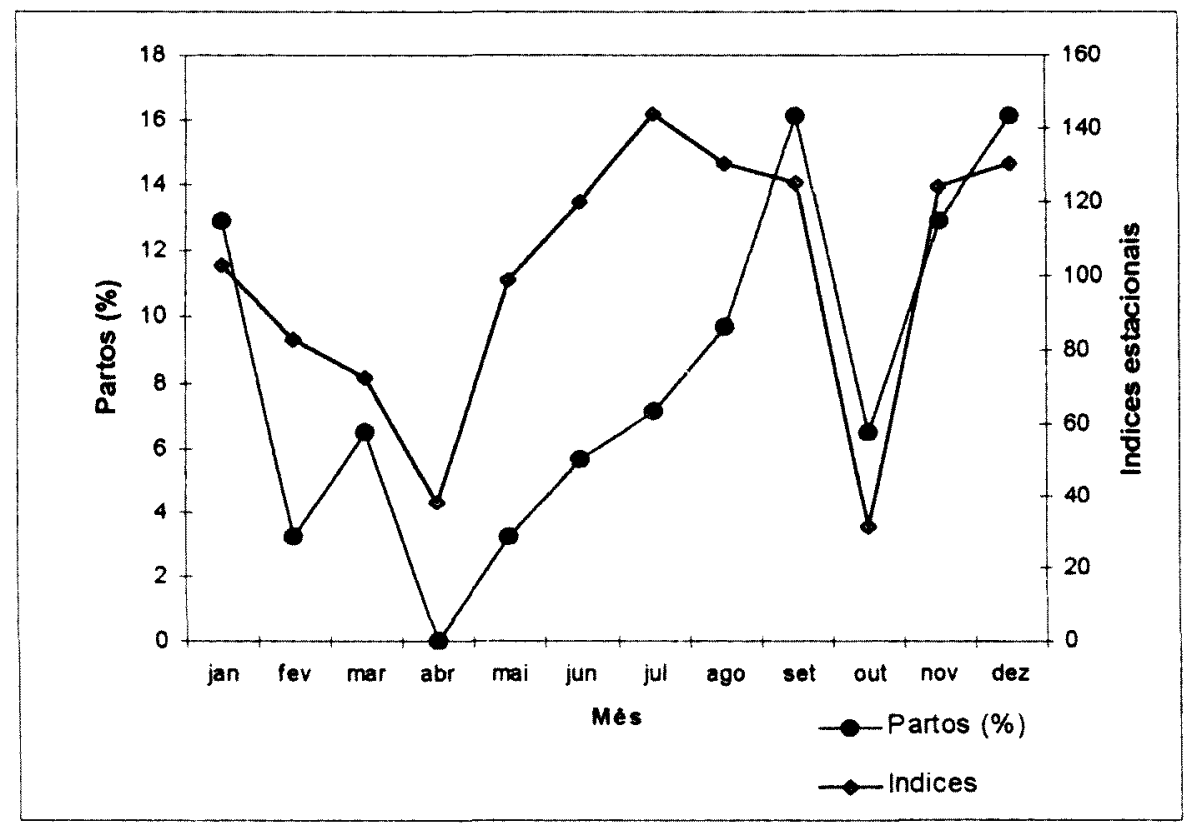

Observa-se que existe semelhança entre as curvas do percentual de partos em cada mês e dos respectivos índices estacionais. Verificou-se que existe uma correlação entre os índices estacionais de raiva e percentuais de nascimentos para cada mês do ano $\left(\mathrm{r}_{\mathrm{s}}=0,73, \mathrm{P}<0,05\right.$; Coeficiente de correlação de Spearman). Valores significantes de correlação foram verificados com o número absoluto de nascimentos para cada mês ou com os respectivos valores percentuais, tanto considerando todos os nascimentos com data registrada ou apenas aqueles ocorridos no período de 12 meses que antecederam a data da entrevista (já que a maior parte das datas recordadas ocorreram em períodos mais recentes, embora haja relatos de datas em anos anteriores). 


\subsubsection{Componente cíclica:}

$\mathrm{Na}$ Figura 15 estão representados os índices cíclicos para os casos de raiva canina notificados na cidade de Recife entre os anos de 1987 e 1997. Observa-se que no último ano da série (1997), ocorreu uma reversão de ciclo, com efeito positivo da componente cíclica sobre a ocorrência de casos de raiva. Até então, a partir de 1989, os índices eram inferiores a 100 , denotando influência negativa do ciclo sobre o número de casos de raiva canina.

Figura 15: relativos de ciclo para casos de raiva canina em Recife / PE, 1987 a 1997.

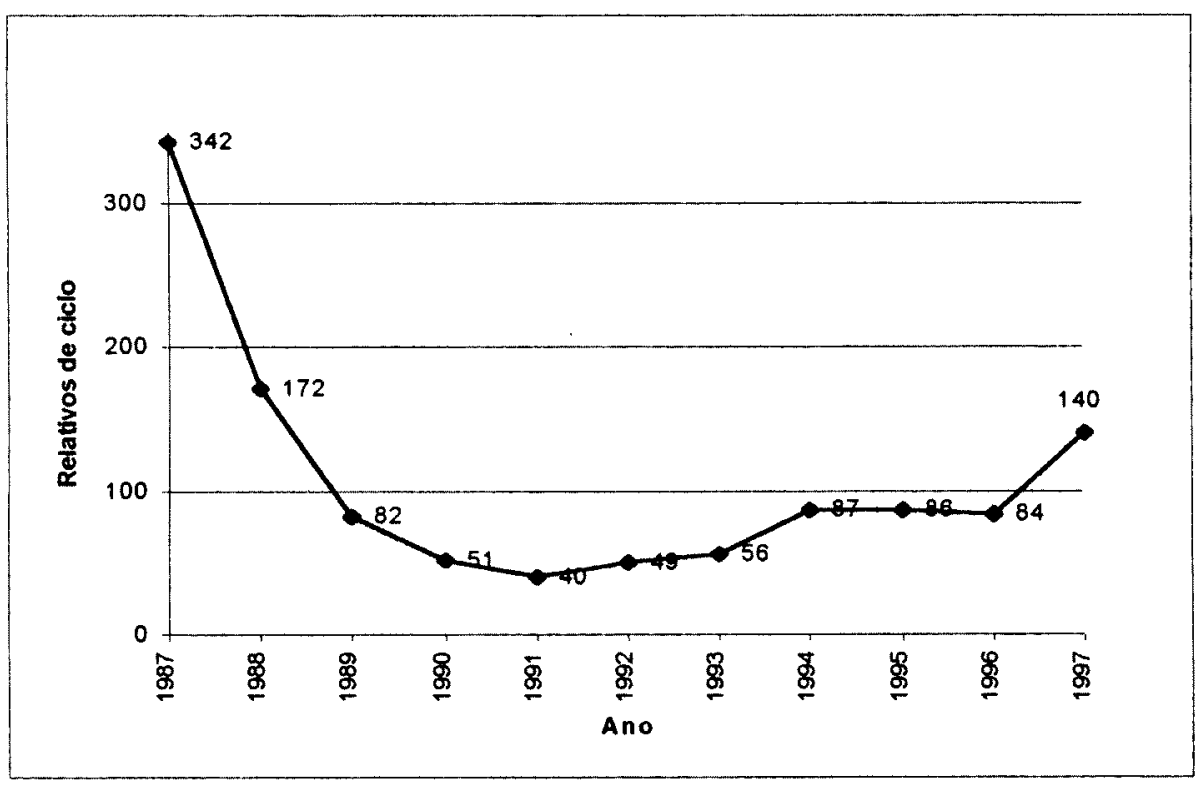

Na Figura 16 pode-se observar o efeito da componente cíclica sobre o número mensal de casos de raiva canina. Observa-se a ocorrência de picos a intervalos regulares, notadamente nos últimos cinco anos da série, a partir de 1993. 
Figura 16: influência percentual dos efeitos cíclicos sobre os casos de raiva canina em Recife / PE, 1987 a 1997.

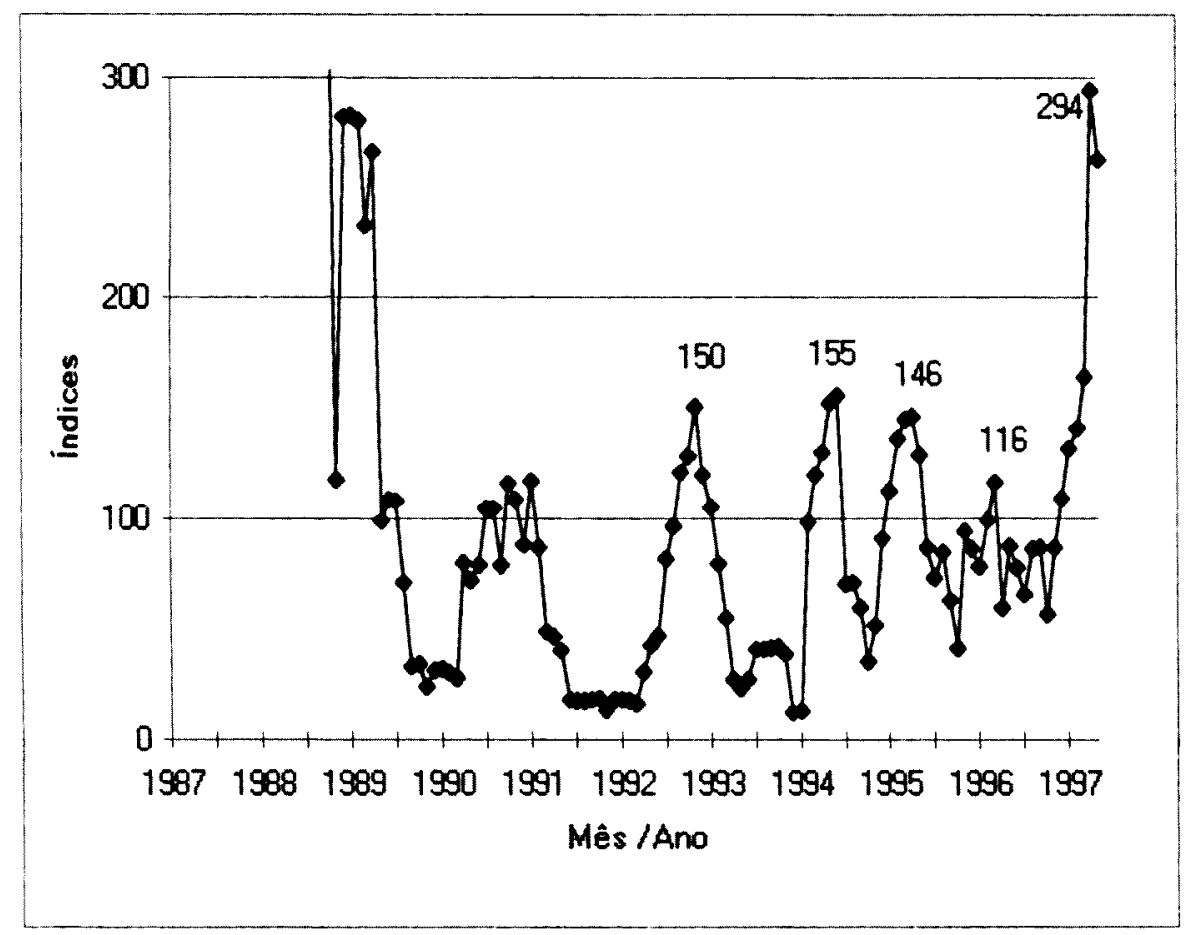

Estes índices ocorreram, respectivamente, em Janeiro de 1993, Agosto de 1994, Junho de 1995, Maio de 1996 e Junho de 1997, e tendem a coincidir com os meses em que ocorrem os maiores índices estacionais. O intervalo entre eles é de 13 meses em média, tendo mediana de 12 meses, correspondente à periodicidade das campanhas, que são anuais. Os picos ocorrem nos meses anteriores e próximos ao mês de setembro, quando ocorre a campanha anual de vacinação anti-rábica canina.

Ressaltam-se dois aspectos importantes à discussão: o primeiro, relativo ao número inesperadamente baixo de casos de raiva canina (e animal) nos anos de 1991 e 1992, quando ocorreram inclusive casos de raiva humana; o segundo, os registros das atividades de controle da raiva existentes no C.V.A / P.C.R. são mais regulares e mais confiáveis a partir de 1994, segundo nossa avaliação. 


\subsection{Avaliação da imunização anti-rábica}

Neste tópico será apresentado um sumário dos principais dados relacionados à imunização contra raiva obtidos a partir do estudo realizado durante a campanha de vacinação anti-rábica de 1995, e também a partir do estudo transversal realizado em 1996. Acrescenta-se também a Figura 17, onde estão representadas as coberturas de vacinação durante o mesmo período de tempo da série histórica analisada. Esta informação é útil para a discussão dos resultados.

Figura 17: cobertura de vacinação em campanhas de vacinação anti-rábica na cidade de Recife, 1987-1997

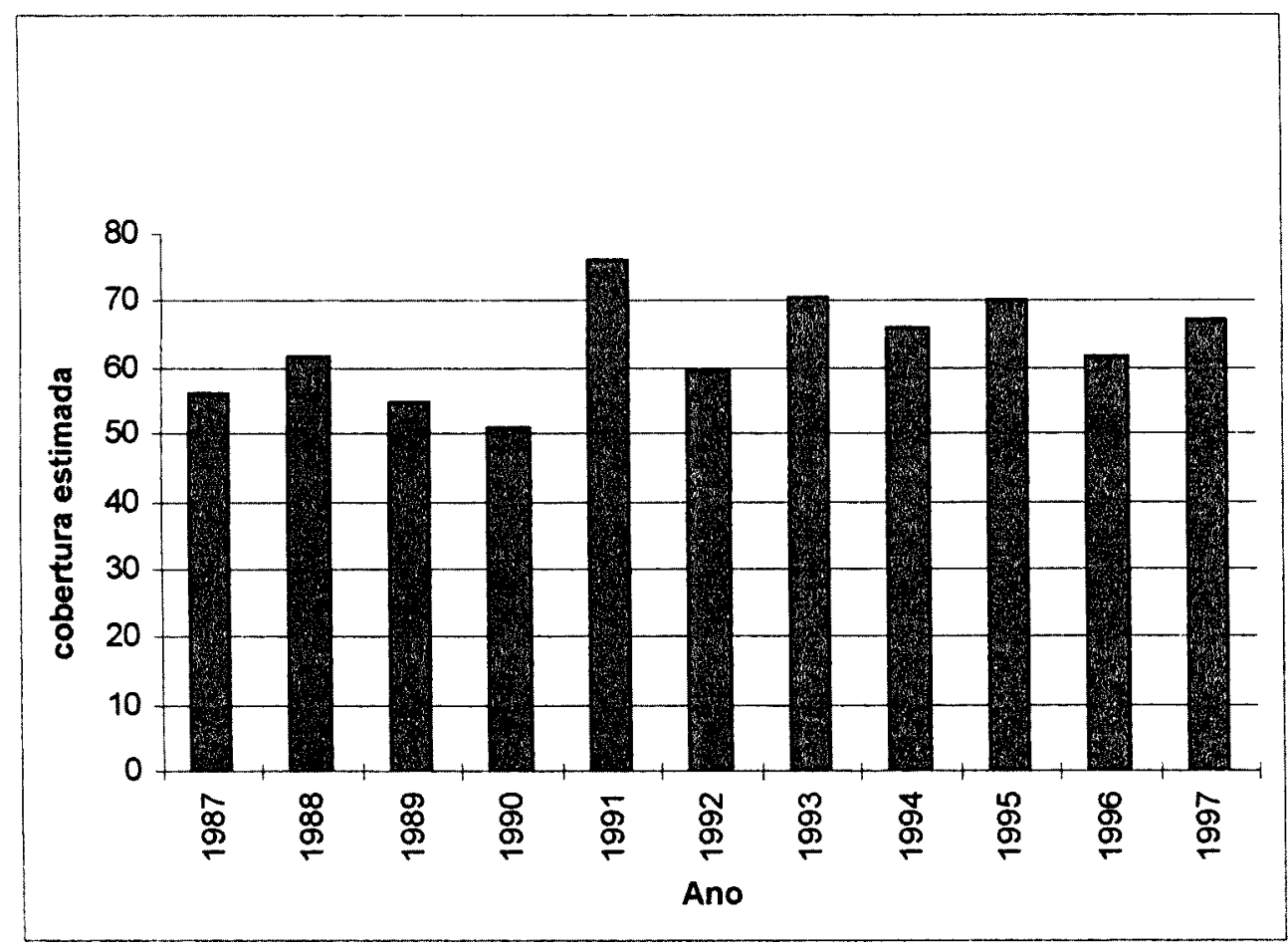

Fonte do dados: CVA / PCR 


\subsubsection{Campanha de vacinação anti-rábica, Recife / PE, 1995}

Foram realizadas entrevistas com 530 cães sorteados, cujos responsáveis foram entrevistados. Apenas dados de interesse direto para as análises foram incluídos nos resultados. A pirâmide etária dos cães vacinados, e a estimativa da idade média à primeira vacinação foram incluídas em outros tópicos dos resultados. Outras informações sobre a campanha de 1995 foram incluídas em relatório a parte, entregue ao CVA / PCR logo após a campanha, juntamente com recomendações.

Algumas estimativas obtidas nesta etapa foram utilizadas para o delineamento do estudo transversal, incluindo determinação do tamanho da amostra.

Nas observações dos trabalhos diários durante a campanha foram identificados, mas não quantificados, inúmeros fatores que podem comprometer a eficiência da imunização anti-rábica em Recife. Estão enumerados a seguir aqueles de maior relevância:

- Conservação inadequada da vacina durante o período de vacinação:

$\checkmark$ exposição demorada da vacina à radiação solar e às altas temperaturas, por deficiência na contenção dos animais;

$\checkmark$ preparação antecipada de seringas com vacina, para adiantar serviço.

$\checkmark$ preparação antecipada das caixas de isopor com gelo, reduzindo o tempo de duração do gelo, o que é agravado pelas altas temperaturas ambientais no mês de setembro.

- Aplicação da vacina incorreta ou ineficiente:

$\checkmark$ aplicação por via incorreta;

$\checkmark$ aplicação de subdoses devido a transfixação da pele, perda de conteúdo para eliminação de bolhas de ar na seringa, ou injeção incompleta do conteúdo.

$\checkmark$ agulhas impróprias, ocasionando demora no preenchimento da seringa ou na inoculação (pequeno diâmetro) ou sangramentos (grande diâmetro).

- Deficiência nas técnicas de contenção e de manipulação dos animais, ocasionando:

$\checkmark$ atraso na vacinação e aumento das filas; 
$\checkmark$ animais retornaram para casa sem vacinação;

$\checkmark$ acidentes com vacinadores e com proprietários, além de risco para terceiros;

$\checkmark$ maus tratos aos animais e traumas;

- Distribuição pouco eficiente e número insuficiente de postos de vacinação:

$\checkmark$ postos com grande afluxo de pessoal, gerando sobrecarga de trabalho, atraso, falta de material e vacinas, o que resulta em atendimento ineficiente.

$\checkmark$ postos com pequeno afluxo de pessoal, ocasionando ociosidade das equipes.

- Apoio deficiente às equipes de vacinação:

$\checkmark$ intervalo prolongado entre visitas do veículo de apoio, ocasionando faltas temporárias ou permanentes de material e vacina.

$\checkmark$ supervisão deficiente e incompleta das atividades.

$\checkmark$ locais de trabalho com conforto, proteção e segurança insuficientes.

- Materiais e equipamentos impróprios:

$\checkmark$ uso de agulhas com diâmetros inadequados.

$\checkmark$ falta de mordaças para cães e de sacos para contenção de gatos.

$\checkmark$ inexistência de kits de primeiros socorros.

$\checkmark$ faixas para identificação dos postos em lugares pouco visíveis.

Ainda foram detectados problemas relacionados a: organização e divisão de tarefas, estabelecimento de diretrizes, insatisfação do pessoal, falta de estímulo à participação comunitária, falhas na divulgação da campanha e falta de notificação de alguns acidentes.

\subsubsection{Estudo transversal}

A situação de vacinação contra raiva dos cães da amostra está sumariada na Tabela 20. Verificou-se uma cobertura de vacinação anti-rábica de 74,5\%, segundo informações dos proprietários, dos quais devem ser excluídos 3,8 \% de animais com vacinação vencida segundo critérios do estudo. Considerou-se vencida a vacinação realizada há mais de doze meses anteriores à data da entrevista. O intervalo médio de tempo entre a data da última vacinação e a data da entrevista foi de 4,5 meses. 92,2 
$\%$ dos animais foram vacinados pela última vez no período de seis meses que antecederam a data da entrevista. O percentual de animais que receberam apenas uma dose da vacina anti-rábica durante a vida foi igual a $23,8 \%$.

Determinou-se a proporção de animais com título de anticorpos $\geq 0,5 \mathrm{UI} / \mathrm{ml}$ em grupos classificados segundo o intervalo de tempo mensal e quinzenal entre a data da última vacinação e a colheita de sangue. Não se observou diferenças no estado de proteção contra raiva entre as diferentes categorias de intervalos de tempo, possivelmente em razão das colheitas terem sido realizadas em um curto período de tempo, insuficiente para permitir que variações importantes nos níveis de anticorpos fossem notadas.

Tabela 20: situação de vacinação anti-rábica em cães de uma amostra de domicílios de Recife / PE, 1996

\begin{tabular}{lc}
\hline \multicolumn{1}{c}{ Situação } & Percentual \\
\hline Vacinado ao menos contra raiva & 74,3 \\
Vacinação anti-rábica vencida (mais de 12 meses) & 3,8 \\
Vacinado, recebeu mais de uma dose da vacina & 78,1 \\
Média de doses de vacina anti-rábica entre os vacinados & 2,85 \\
Cães primovacinados & 23,8 \\
Vacinado em campanha & 82,2 \\
\hline
\end{tabular}

A maior parte dos animais foi vacinada em campanha $(82,2 \%)$, seguida de vacinação por veterinários $(12,5 \%)$, vacinação por agentes públicos no domicílio $(3,6 \%)$, e $1,8 \%$ dos animais foram vacinados pelos próprios donos ou outras pessoas. Durante as entrevistas foram identificados alguns casos de possível vacinação por pessoal não autorizado estranho ao domicílio, embora em número reduzido. A proporção de animais vacinados em campanha apresentou diferenças entre Distritos Sanitários $\left(X^{2}=17,83,5\right.$ g.1., $\left.\mathrm{P}<0,01\right)$, variando entre 76 e $97 \%$.

O número de doses de vacina anti-rábica recebidas durante a vida do animal está correlacionado com a idade dos animais $\left(\mathrm{r}_{\mathrm{s}}=0,84, \mathrm{P}<0,01\right)$, o que reforça a 
informação de que a maior parte dos animais é vacinada e revacinada nas campanhas anuais de vacinação anti-rábica.

Acreditava-se de início que existia temor numa parcela da população em vacinar seus cães contra raiva, por motivos como medo de "transmissão de doenças" e até conceitos sem fundamentos, como o de que "cães vacinados podem transmitir a raiva sem ter a doença". De fato, através das entrevistas constatou-se algumas restrições de pessoas quanto à vacinação em campanhas públicas, geralmente associadas a traumas e doenças dos animais que apareceram após a vacinação em campanha. Entretanto, a maioria destas pessoas ainda vacinavam seus animais em campanha, ou optavam pela vacinação por Veterinários. Dentre os motivos citados para o animal do domicílio não ter sido vacinado, constatou-se que $76,9 \%$ não o fizeram por ser o animal muito novo no período da vacinação, 7,7 \% não vacinaram o cão por estarem há pouco tempo com os mesmos, $7,7 \%$ mencionaram que os animais eram muito bravos, o que impediu a vacinação, e outros 7,7 \% não souberam informar o motivo.

Dentre os cães da amostra de domicílios, apenas $32 \%$ apresentavam títulos de anticorpos contra raiva $\geq 0,5 \mathrm{UI} / \mathrm{ml}$ (boa resposta), e a distribuição de freqüência dos títulos de anticorpos na amostra está representada na Figura 18. 
Figura 18: distribuição de freqüência dos títulos de anticorpos contra raiva, segundo a idade, em cães de uma amostra de domicílios de Recife / PE, 1996

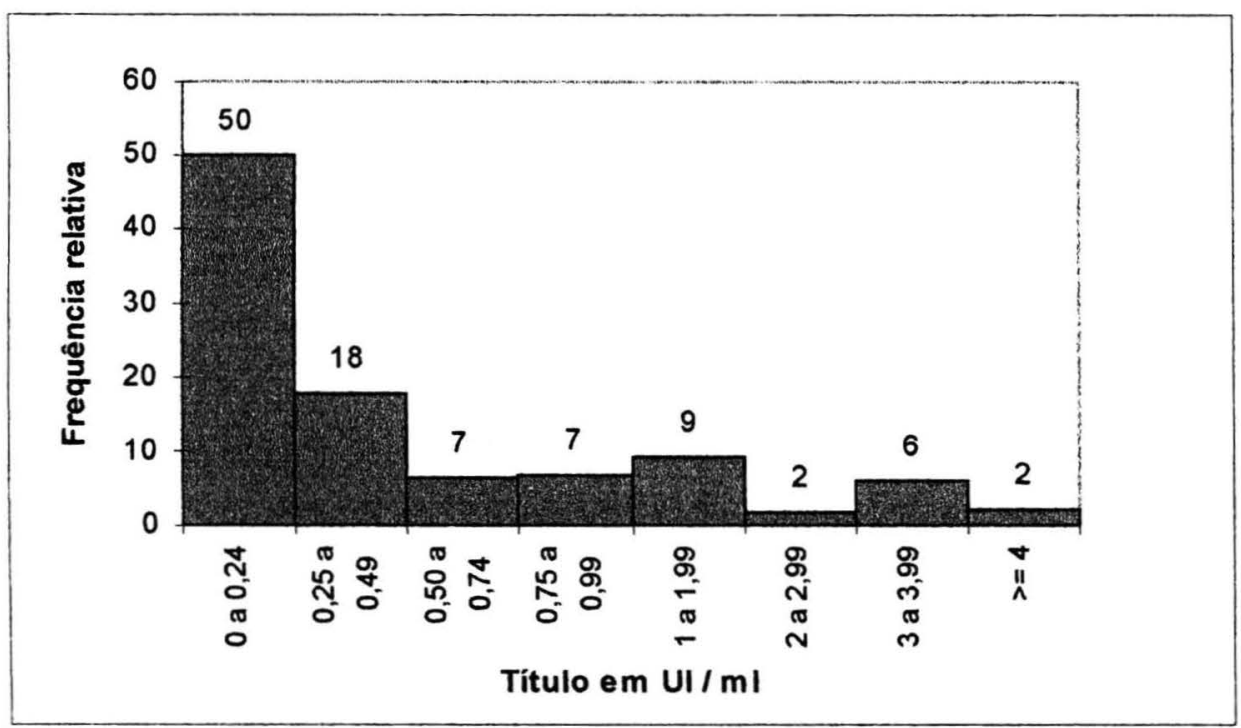

$\mathrm{O}$ percentual de animais com títulos $\geq 0,5 \mathrm{UI} / \mathrm{ml}$, segundo a idade, está representado na Figura 19. Observa-se que à medida que aumenta a idade, aumenta a proporção de animais com boa resposta, embora nenhum grupo etário tenha apresentado este resultado em $50 \%$ ou mais dos animais. Observou-se diferenças significantes entre as medianas dos títulos de anticorpos de animais classificados em grupos etários (Análise de Variância de Kruskal-Wallis $\mathrm{H}=33,9,6$ g.l, $\mathrm{P}<0,01$, Epilnfo). 
Figura 19: proporção de animais com títulos $\geq 0,5 \mathrm{UI} / \mathrm{ml}$ (boa resposta), segundo a idade em meses, em cães de uma amostra de domicílios, Recife / PE, 1996

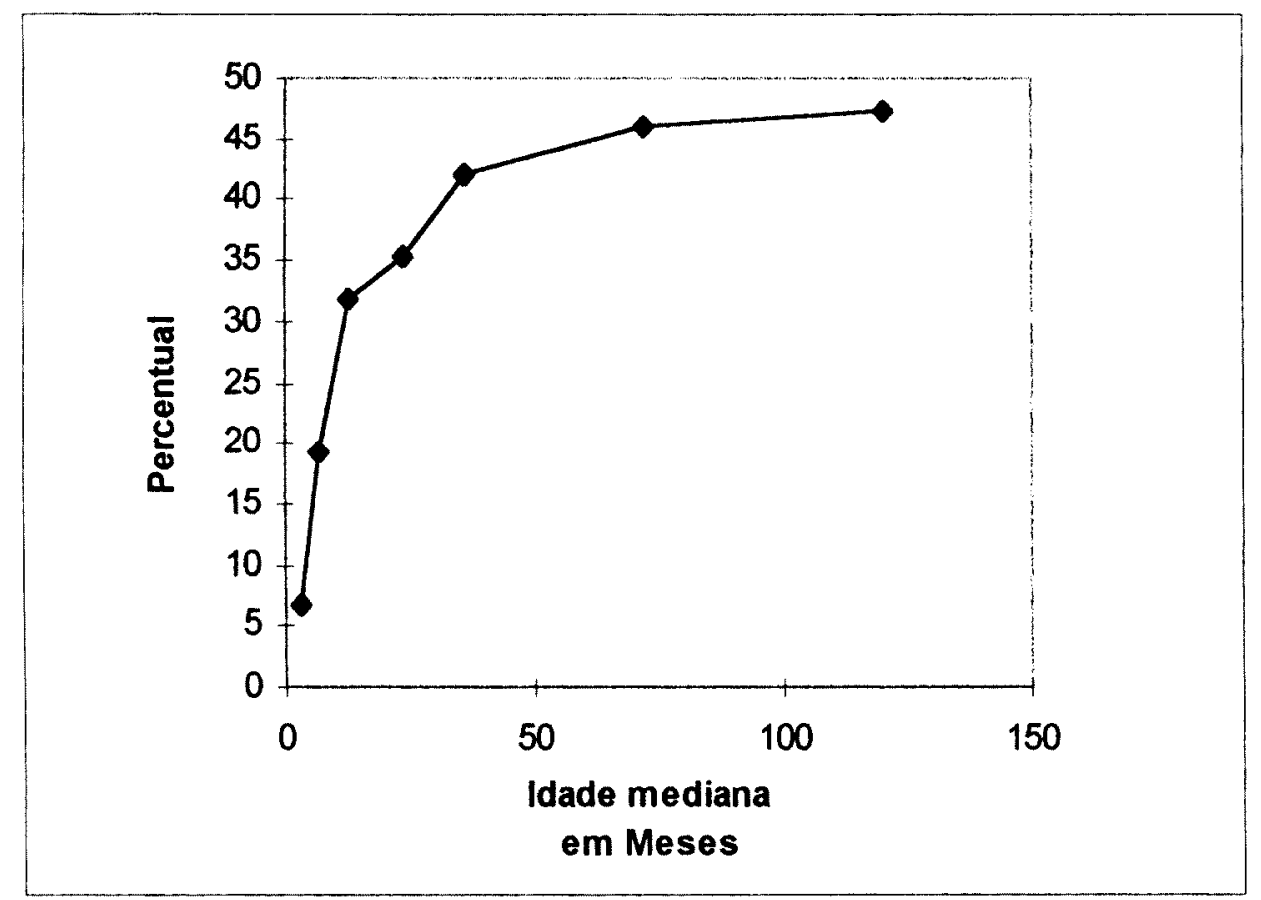

Foram estimados os valores da mediana dos títulos de anticorpos para diferentes categorias de animais classificadas segundo o número de doses de vacina anti-rábica recebidas durante a vida. Verificou-se que existe correlação entre o número de doses de vacina recebidas e a mediana do título de anticorpos contra a raiva das diferentes categorias $\left(r_{s}=0,82, P<0,05\right)$. Existem diferenças significantes entre as medianas dos títulos de anticorpos das diferentes categorias de número de doses (Análise de Variância de Kruskal-Wallis $\mathrm{H}=59,9,14$ g.l., $\mathrm{P}<0,01$, EpiInfo).

As variáveis Idade do animal, número de vezes que estes foram vacinados contra raiva durante a vida e o título de anticorpos estão correlacionadas positivamente.

Avaliou-se através de análise de regressão logística, um modelo considerando o "estado de proteção" contra raiva a variável dependente (boa resposta $=$ título $\geq$ 
0,5 UI $/ \mathrm{ml}$ ), e as variáveis idade e número de doses de vacina como variáveis independentes.

Verificou-se que o número de doses é a variável que melhor explica o estado de proteção contra raiva, não se constatando entretanto diferenças significantes entre categorias que receberam uma ou mais doses da vacina anti-rábica. O tamanho da amostra limita a realização de uma análise por categorias, e a adoção de um limiar de proteção implica em se avaliar de forma diferente as variáveis títulos de anticorpos e estado de proteção contra raiva.

Não se verificou diferenças no estado de proteção contra raiva entre animais de diferentes sexos, níveis de restrição e dependência, categorias, nem entre animais vacinados em campanha ou por veterinários. Entretanto, a mediana do título de anticorpos tendeu a ser maior em animais vacinados por veterinários $(0,4 \mathrm{UI} / \mathrm{ml})$ do que em animais vacinados em campanha $(0,26 \mathrm{UI} / \mathrm{ml})$.

\subsubsection{Estudo dos animais capturados no Centro de Vigilância Animal da Prefeitura da Cidade de Recife}

Cães capturados pelo CVA / SS / Recife estão insuficientemente protegidos, independente da idade, sexo e procedência. Não há diferenças quanto ao estado de proteção entre animais de diferentes idades, sexos e procedências. Apenas 14,5\% dos cães capturados apresentaram títulos de anticorpos $\geq 0,5 \mathrm{UI} / \mathrm{ml}$ de soro. Estes cães possuem títulos cujo valor médio é igual a $0,3 \mathrm{UI} / \mathrm{ml}($ mediana $=0)$

$\mathrm{Na}$ Figura 20 está representada a distribuição de frequência dos níveis de anticorpos em animais capturados pelo CVA. 
Figura 20: distribuição de freqüência dos títulos de anticorpos contra raiva, segundo a faixa etária presumida, em cães capturados pelo Centro de Vigilância Animal da P.C.R., Recife / PE, 1996

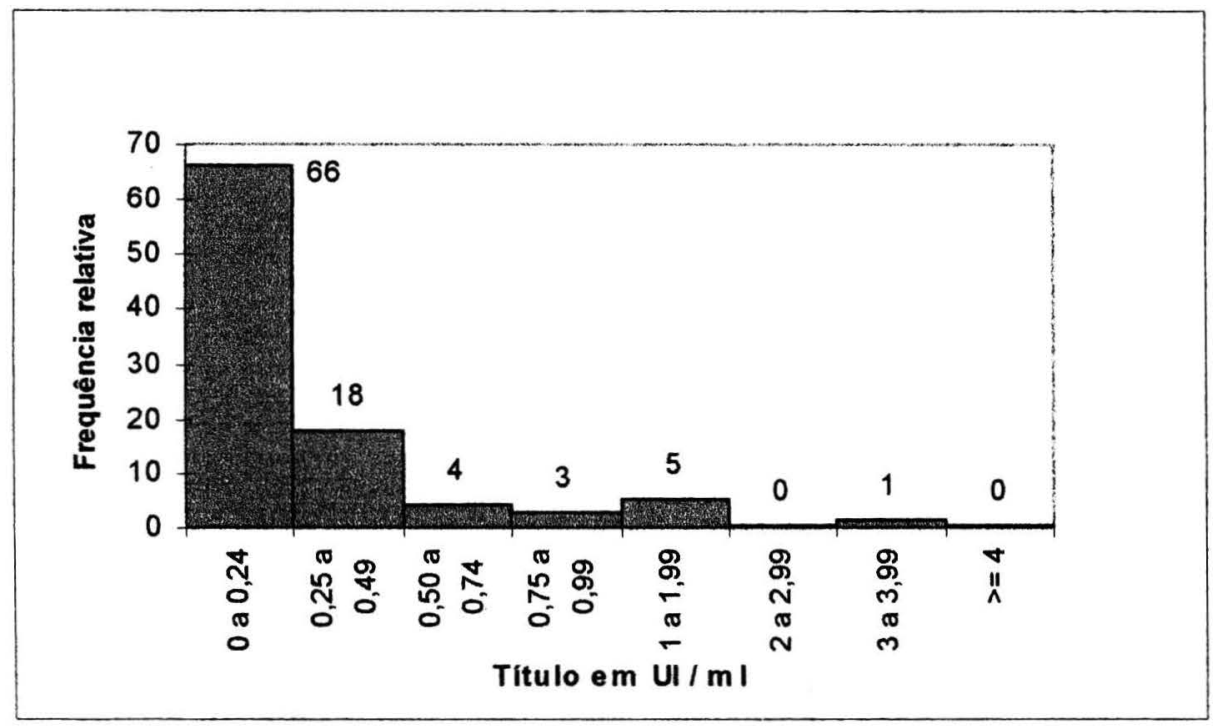

$\mathrm{O}$ percentual de animais com título $\geq 0,5 \mathrm{UI} / \mathrm{ml}$, de acordo com o grupo etário, está representado na Figura 21. Observa-se pelo gráfico que a proporção de animais com título $\geq 0,5 \mathrm{UI} / \mathrm{ml}$ aumenta constantemente, conforme aumenta a idade do grupo etário, mas ela está sempre abaixo de $30 \%$ dos animais da categoria. Entretanto, as diferenças entre os valores das medianas dos títulos de anticorpos dos diferentes grupos etários não são significantes, o que em parte pode ser explicado pelo reduzido número de animais capturados pertencentes às categorias 1 (filhotes de 1 a 3 meses) e 4 (animais velhos, com idade presumida acima de 7 anos). 
Figura 21: proporção de animais com título $\geq 0,5 \mathrm{UI} / \mathrm{ml}$, segundo a faixa etária presumida, em uma amostra de cães capturados pelo Centro de Vigilância Animal da P.C.R., Recife / PE, 1996.

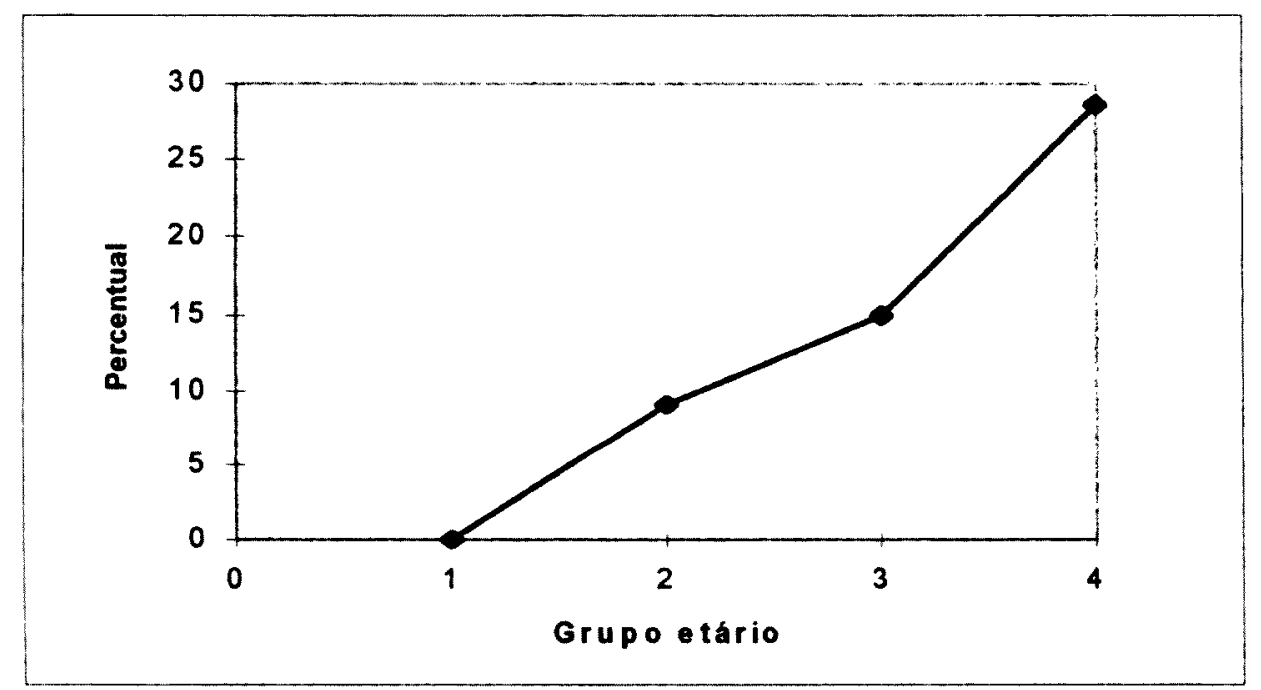




\subsection{Resultados das Simulações}

\subsubsection{Influência da vacinação sobre a dinâmica da raiva}

A curva sorológica dos cães de Recife, ajustada a partir da equação 6, está apresentada na Figura 22. Verifica-se que a proporção máxima de "vacinados imunes" (conforme definido em procedimentos metodológicos) só é atingida em idade tardia, próximo aos 50 meses de idade.

Figura 22: curva ajustada de anticorpos contra raiva em cães de Recife / PE, 1996

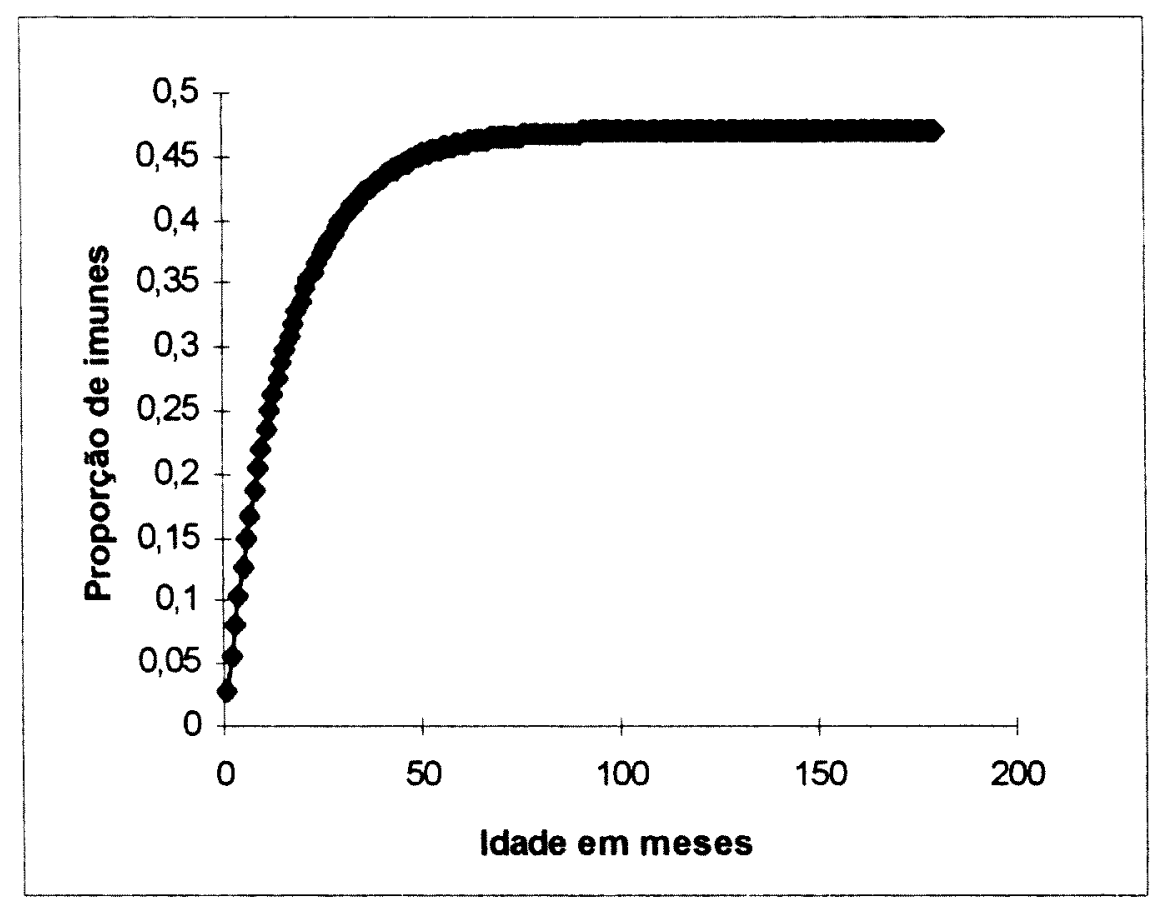

Foram realizadas simulações com taxas de vacinação variando entre 1,2 e 3,0, sendo 1,2 a taxa de vacinação para a população canina de Recife, no periodo de estudo, estimada a partir da curva de soroprevalência. Um aumento de 2,5 vezes na taxa de vacinação produziu uma redução de aproximadamente 24 vezes na taxa de 
infecção $(\lambda)$ e uma redução de aproximadamente 22 vezes no número de animais infectados (não infecciosos e infecciosos - $\mathrm{H} \mathrm{e} \mathrm{Y}$, respectivamente).

Considerando a relação entre a taxa de vacinação e a idade média à primeira vacinação, observou-se que uma redução de 2,5 vezes na idade à primeira vacinação, ou seja, uma redução de 10 meses para 4 meses nesta idade, foi acompanhada por redução nas taxas de infecção e número de infectados, da mesma magnitude observada com a taxa de vacinação.

As Figura 23 e Figura 24 ilustram os relacionamentos observados nesta etapa das simulações numéricas.

Figura 23: relação entre a taxa de vacinação anti-rábica e o número de animais infectados (por 100.000 cães), Recife / PE, 1996.

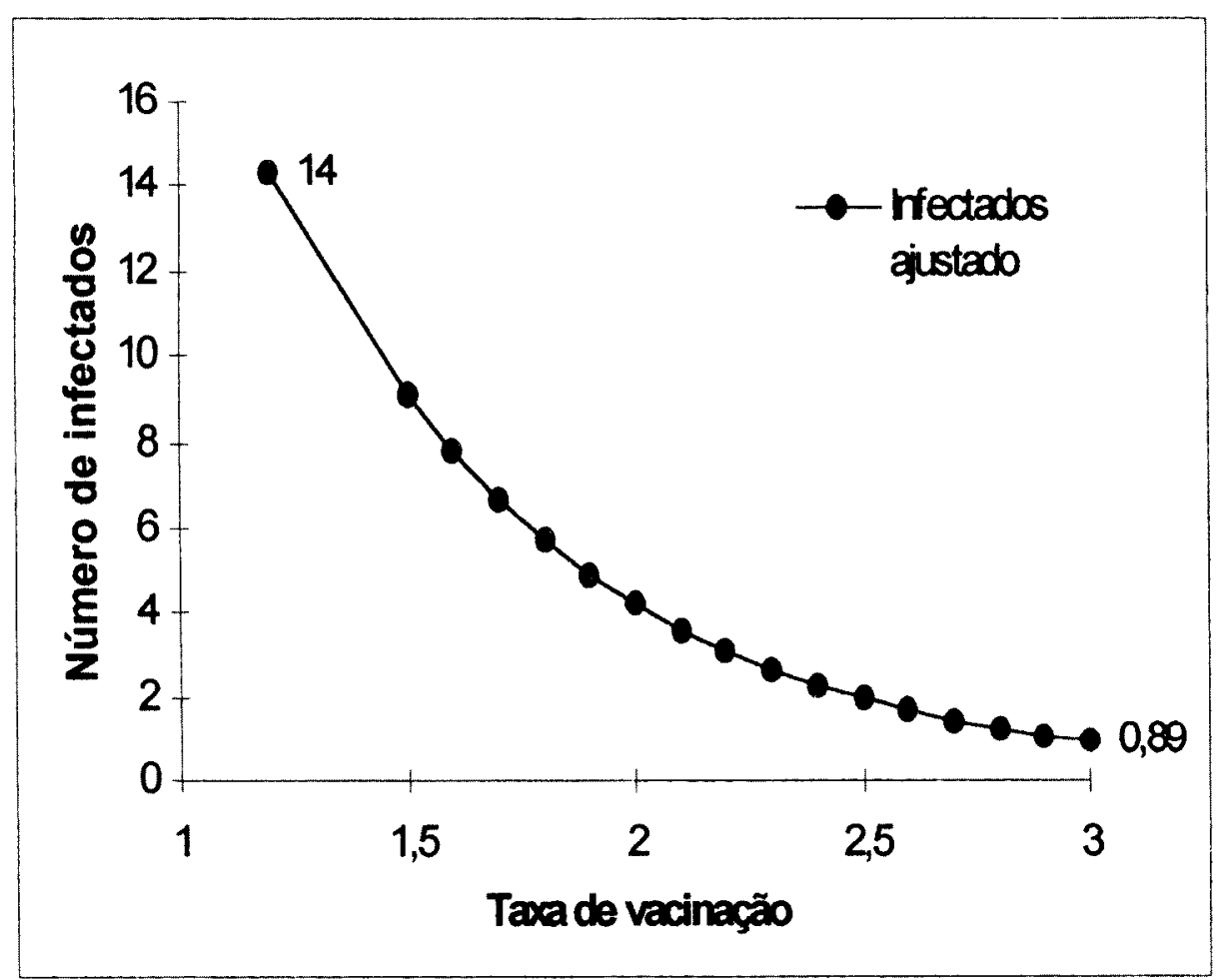


Figura 24: relação entre a idade média à primeira vacinação contra raiva, e a taxa de infeç̧ão pela doença, Recife / PE, 1996

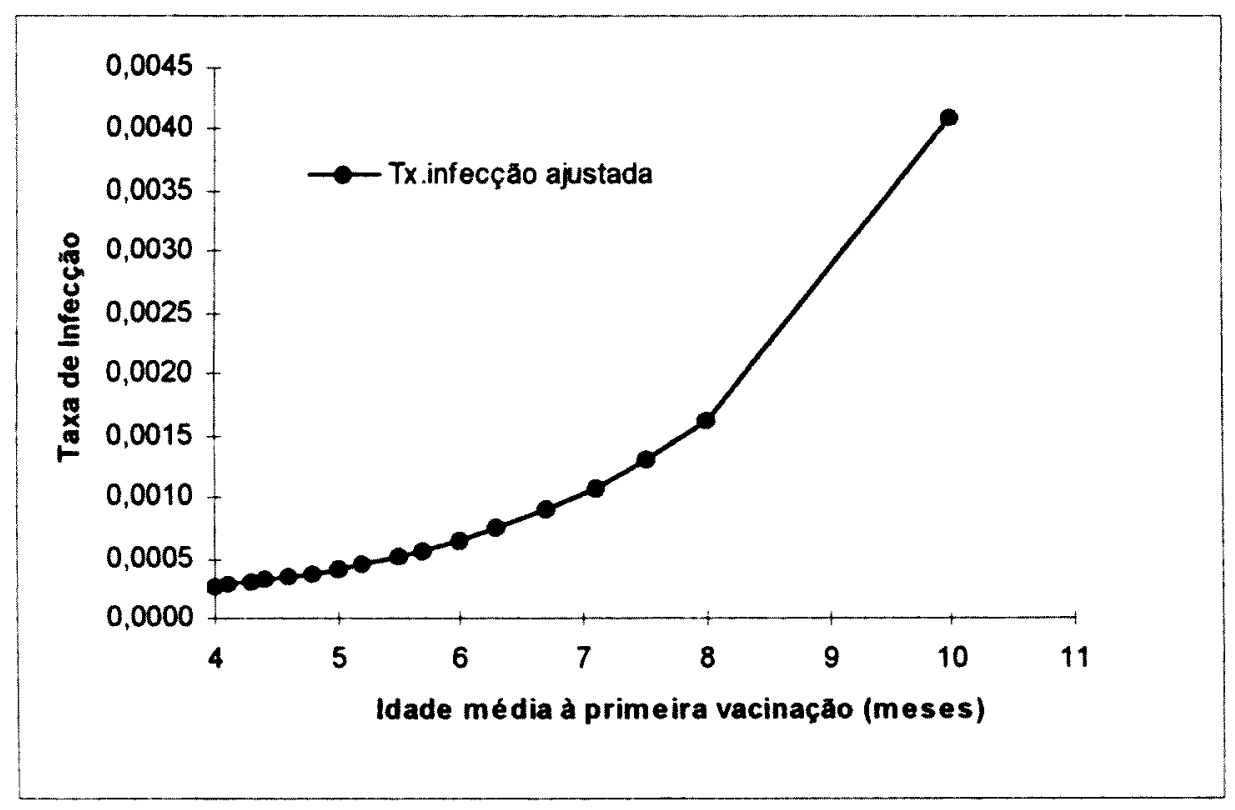

\subsubsection{Influência da perda de imunidade sobre a dinâmica da raiva}

A Figura 25 ilustra a variação no número de animais infectados $(\mathrm{H}+\mathrm{Y}) \mathrm{em}$ função da taxa de perda de imunidade $(\delta)$. Nas simulações, $\delta$ apresentou valores entre 3,5 e 0,5. A taxa de perda de imunidade para a população canina de Recife, no período de estudo, estimada a partir da curva de soroprevalência, é igual a 3,2. O inverso de $\delta$ corresponde à duração média da imunidade, e equivale ao período de 3,75 meses. Uma redução em sete vezes no valor de $\delta$ produziu uma redução de aproximadamente duas vezes no número de animais infectados. 
Figura 25: efeito da taxa de perda de imunidade contra raiva sobre o número de animais infectados (por 100.000 cães), Recife / PE, 1996

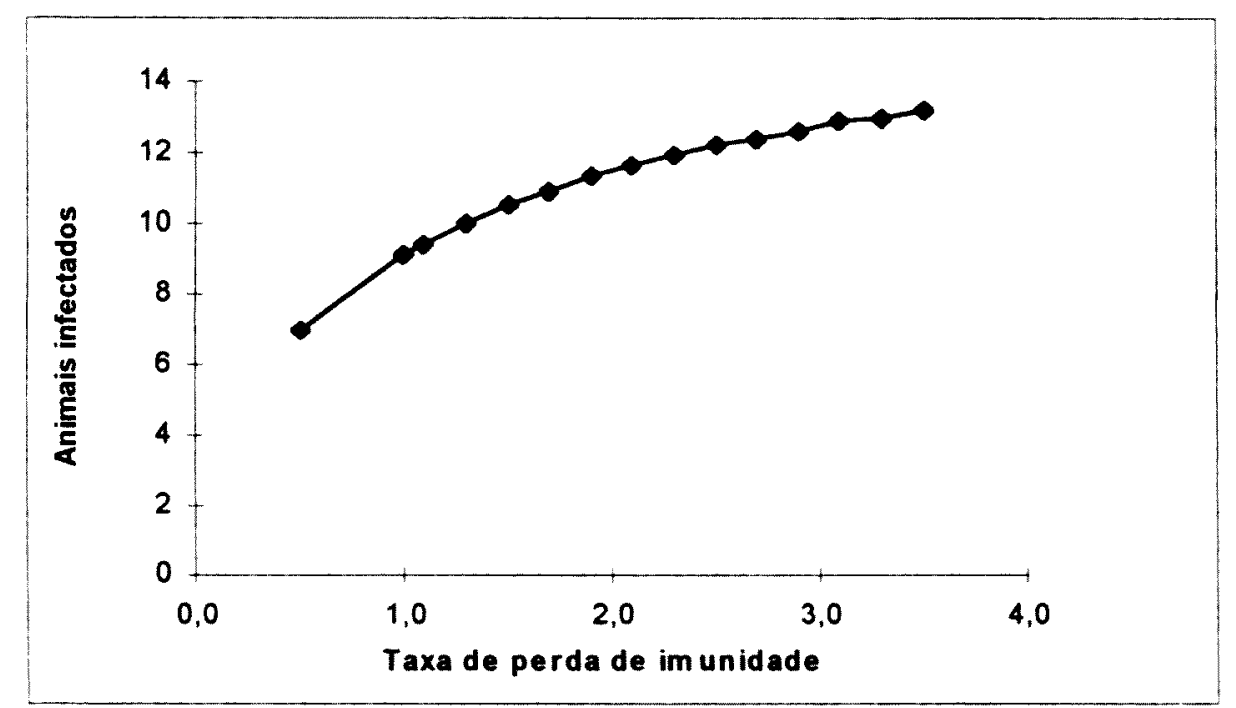

\subsubsection{Influência da mortalidade sobre a dinâmica da raiva}

O número esperado de animais infectados para diferentes taxas de mortalidade ( $\mu$ ) foi estimado a partir da equação 13. Nas simulações, $\mu$ variou entre 0,2 e 0,4 . Estimou-se, para a população canina de Recife, no período de estudo, $\mu=0,31$, que equivale a uma expectativa de vida média de 38,7 meses. Este valor utilizado na simulação foi ligeiramente inferior à estimativa final da idade média de 39,84 meses (resultaria em $\mu=0,301$ ), a qual incluiu animais que foram classificados apenas por grupo etário.

$\mathrm{Na}$ equação 13, o número de animais infectados depende de $\sigma, \beta, \mu$ e $\alpha$. Variando $\beta$ entre 46,6 e 50, e mantendo os demais valores constantes, observa-se que as taxas de mortalidade exercem efeitos variáveis sobre o número de animais infectados, como pode-se observar na Figura 26.

De uma maneira geral, o número de animais infectados tende a aumentar à medida que as taxas de mortalidade aumentam, a partir dos valores mínimos até valores próximos da taxa de mortalidade estimada para a população de estudo, ou 
seja, $\mu=0,31$. A partir dai, com valores menores de $\beta$ as curvas apresentam mudança de tendência, o que deixa de ocorrer à medida que o valor de $\beta$ se aproxima de 50. Ou seja, com valores de $\beta$ se aproximando de 50 , o número de infectados é sempre crescente com o aumento das taxas de mortalidade.

Figura 26: efeito da mortalidade sobre o número de casos de raiva (por 100.000 cães), com valor de $\beta$ variável, Recife / PE, 1996

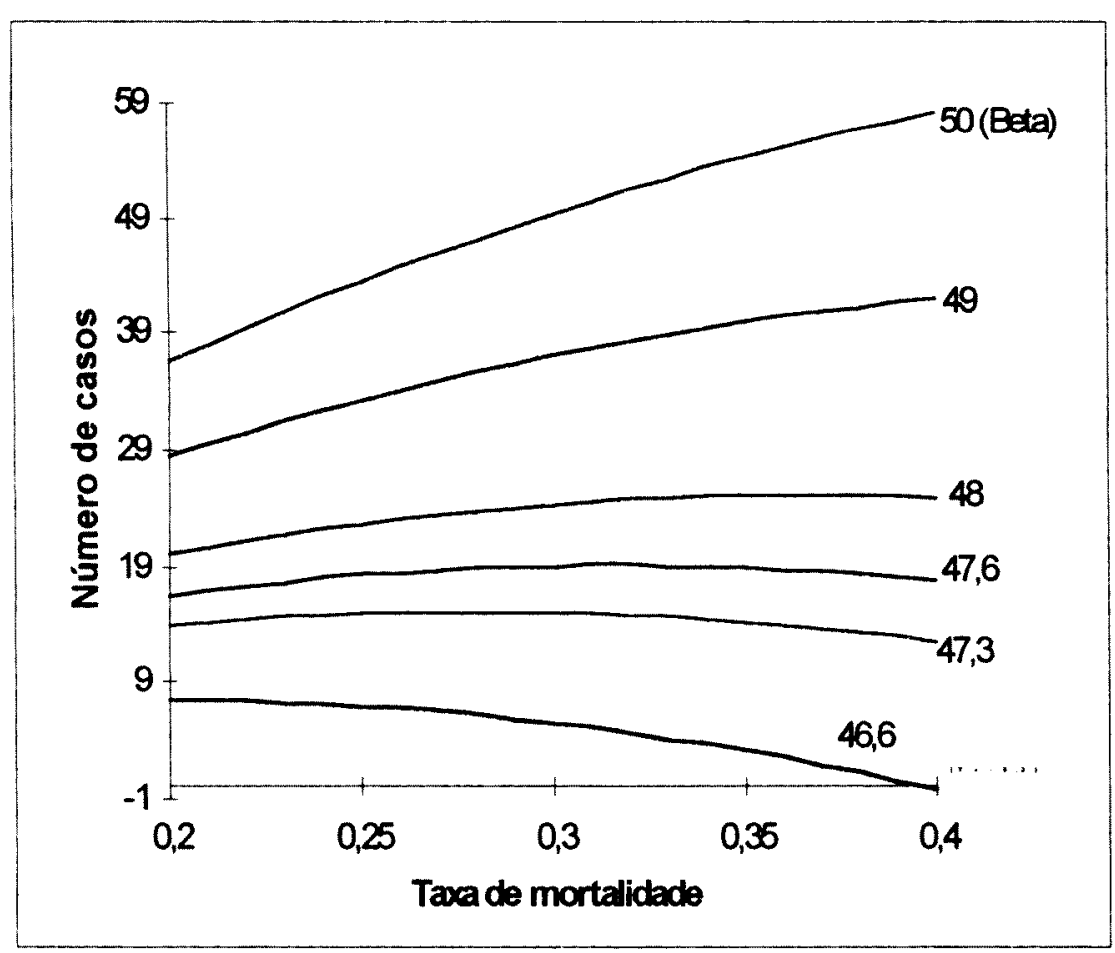




\section{Discussão}

\subsection{Aspectos de representatividade e confiabilidade da amostra}

Alguns aspectos podem ser considerados no momento de avaliar a representatividade da amostra de domicílios.

De uma maneira geral, estimativas realizadas a partir de dados da amostra foram próximas aos dados do último Censo de 1991, embora tenham ocorrido pequenas diferenças.

O intervalo para a média de pessoas por domicílio $(4,27$ a 4,73), não incluiu a média de 4,23 apontada pelo Censo (IBGE, 1991). Além das chances da estimativa diferir do verdadeiro valor populacional, é possível que tenha ocorrido aumento nesta média entre 1991 e 1996. Em função da crise econômica do país, filhos casados e respectivas famílias, além de parentes, poderiam estar vivendo mais com seus pais e / ou familiares em um mesmo teto.

. Neste estudo, $7,14 \%$ dos moradores $(6,3$ a 8,6$)$ da amostra tinham entre 0 e 4 anos de idade, e 18,95\% tinham idade acima de 50 anos $(16,0$ a 21,9), em contraste com $9,9 \%$ e $14,7 \%$, respectivamente, indicados pelo censo do IBGE em 1991. Essas diferenças podem ser casuais ou podem estar ocorrendo pequenas mudanças na estrutura etária da população.

Informações do IBGE obtidas na Base de dados do estado (CONDEPE), indicam as seguintes estimativas para a cidade de Recife, no ano de 1991:

a) Chefes de domicilio com renda de até 1 salário mínimo: $36,7 \%$

b) Chefes de domicílio com renda de até 2 salários mínimos: $56,4 \%$

c) Taxa de analfabetismo em pessoas de 15 anos ou mais: $14,9 \%$.

d) Domicílio particulares urbanos com esgotamento sanitário inadequado: $60,5 \%$

e) Domicílio particulares urbanos com tratamento de lixo inadequado: $17,5 \%$ 
Neste estudo, estimou-se a renda per capita familiar e não a renda do chefe do domicílio, e 17,15\% dos domicílios (13,5 a 20,8) tinham renda per capita familiar de até um salário mínimo, e $36,60 \%$ dos domicílios $(29,9$ a 43,1) tinham renda per capita familiar de até 2 salários mínimos. Deve ser considerado para comparação, que em uma fração dos domicilios da população a renda do chefe da familia é complementada pelos rendimentos de uma ou mais pessoas.

Para este trabalho, a informação de instrução referia-se apenas ao chefe de familia, dos quais $9,26 \%$ não tinham instrução $(6,5$ a 12,0$)$, e 7 \% não tinham instrução formal mas sabiam ler $(5,1$ a 9,0$)$. Estes valores parecem compativeis com os $14,9 \%$ de analfabetismo em maiores de 15 anos apresentados pelo IBGE, pois os chefes de família são uma fração da população com idade a partir de 15 anos, e o analfabetismo deve ser proporcionalmente maior nas faixas de idade superiores.

Estimou-se que $43,45 \%$ dos domicílios não tinham saneamento $(32,2$ a $54,65)$, em contraste com $60,5 \%$ de domicílios particulares com esgotamento sanitários considerados inadequados, apontados pelo IBGE. As diferenças podem indicar casualidade, diferenças de critério de classificação ou mesmo melhoria no serviço de saneamento.

$\mathrm{Na}$ amostra, somando-se colheita irregular de lixo, colheita inexistente e colheita apenas uma vez por semana, obtém-se $13,5 \%$ de domicilios com colheita de lixo inadequada (7,6 a 19,4\%), em contraste com o valor de $17,5 \%$ do IBGE, cujo valor está incluído no intervalo estimado. Mas cabem as observações já feitas anteriormente.

O tempo transcorrido entre a data de realização do último Censo Demográfico e a data de realização do estudo transversal, em um período de grandes mudanças econômicas e sociais, provavelmente explica parte das diferenças encontradas.

Foram encontradas duas áreas, em dois setores censitários, que apresentavam grandes diferenças em relação aos croquis utilizados no Censo de 1991 do IBGE, podendo ter ocorrido um aumento na quantidade de domicílios na cidade de Recife, especialmente aqueles domicílios em áreas subnormais, construídos em áreas invadidas. 
Pouco menos de $70 \%$ das entrevistas foram realizadas com os próprios moradores do domicílio (proprietários ou familiares residentes), subindo este número para $71,5 \%$ quando também são consideradas as entrevistas com empregados dos domicílios. As recusas propriamente ditas (recusa total), constituíram $2,8 \%$ das entrevistas. Considerando os demais casos, excetuando os domicílios desocupados e com pessoas ausentes $(7,6 \%)$, aproximadamente $18 \%$ das entrevistas foram realizadas com terceiros, comumente vizinhos e parentes, como foi descrito anteriormente.

As implicações daí decorrentes foram minimizadas porque as entrevistas com terceiros, em grande parte das vezes, realizaram-se com pessoas que aparentavam um grande conhecimento da situação daquele domicílio em particular e de seus moradores. Nestes casos, os entrevistados eram, muitas vezes, pais, irmãos, parentes ou amigos próximos, os quais eram localizados pelos entrevistadores, nas proximidades do domicílio sorteado, a partir de informações da vizinhança.

Nesta época, ainda existe em diversas áreas de Recife, um tipo de relacionamento mais estreito entre vizinhos, num tipo de convivência que tende a desaparecer pouco a pouco com o crescimento dos centros urbanos. Dentre outras coisas, essas pessoas possuíam acesso ao interior do domicílio cujo dono estava ausente, demonstrando até acessibilidade aos cães porventura existentes. Isto tende a aumentar a confiabilidade das informações obtidas nas entrevistas com terceiros, particularmente devido à natureza das informações utilizadas no trabalho.

\subsection{A amostra e suas caracteristicas : perfil geral dos domicilios, seus habitantes e aspectos relevantes para o estudo}

As estimativas descrevem uma maioria de domicílios do tipo térreo $(71,8 \%)$, o que favorece a criação de animais. Aproximadamente $30 \%$ dos domicílios não contam com proteção adequada, que permita a restrição dos animais, o que foi observado com maior freqüência em áreas pobres, onde as construções eram 
precárias e geralmente inacabadas, além de apresentarem menor área útil geral e relativa ao número de habitantes.

A maioria dos domicílios conta com a existência de serviço de colheita de lixo realizada mais de uma vez por semana $(86,6 \%)$, mas apesar disso, facilita o acesso dos animais aos resíduos domésticos, ao deixar o seu lixo em locais não protegidos $(59,7 \%)$ ou mesmo em locais que além de não protegidos, são completamente impróprios para destinar os resíduos domiciliares (terrenos, rios, etc, em $13,6 \%$ dos casos).

Os locais onde o serviço de colheita de lixo é precário tendem a se concentrar nas áreas pobres da cidade $(\mathrm{P}<0,01)^{18}$, que cresceram desordenadamente, dificultando, desta forma, a prestação de serviços básicos. Muitas casas foram construídas na forma de palafitas, sobre as águas de pequenos canais, sobre o aterro de mangues, ou sobre barreiras ou encostas de morro, e nestes lugares o serviço de colheita de lixo é difícil ou inviável, sobretudo nas épocas chuvosas.

Pelo exposto, verifica-se que ainda existem muitos domicilios na cidade que não são atendidos por um serviço de colheita de lixo, ou ao menos por um serviço de colheita regular. Nos locais em que há colheita regular, na maioria das vezes o lixo é deixado em local desprotegido e de fácil acesso aos animais.

Torna-se evidente o fato de que é comum na população da cidade, o hábito de colocar o lixo em terrenos baldios, ruas, canais, córregos e rios, o que proporciona, além dos graves e nítidos prejuízos ambientais, condições que favorecem a manutenção e multiplicação de cães que não estão submetidos a um regime de supervisão e restrição adequados. Este situação, sem dúvida, favorece a abundância de cães errantes, e em conseqüência, favorece a manutenção do vírus rábico na população canina.

Ainda existem muitos chefes de família analfabetos ou sem instrução formal $(16,3 \%)$, ou que têm apenas formação escolar primária incompleta $(32,4 \%)$. Mais

\footnotetext{
18 Para este e demais valores entre parêntesis neste tópico, ver tabela de correlações entre variáveis estimadas para as diferentes UPAs (Anexo VI).
} 
uma vez, esta característica tende a se concentrar nas áreas mais pobres da cidade $(P$ $<0,01)$.

Este perfil geral aqui descrito, tende a favorecer a criação de animais em condições impróprias de supervisão e restrição, principalmente nos setores mais pobres da cidade $(\mathrm{P}<0,01)$. A população como um todo cria cães, mas grande parte dela não tem condições de atender às exigências mínimas para tal. Como resultado, observamos elevadas densidades de cães, associadas a elevadas densidades de pessoas.

A abundância de lixo e a incompleta restrição dos animais criam um ambiente favorável aos cães errantes, e essas características são mais acentuadas em setores pobres, aqueles que sofrem as maiores conseqüências do fenômeno, muito embora tais efeitos não sejam exclusividade destas áreas, pois os cães não têm movimentação limitada a esses setores mais desfavorecidos. Mais uma vez, ressalta-se que o uso do termo cão errante, neste texto, refere-se a cães com certa liberdade de movimentação, e não necessariamente cães "sem dono" ou "perdidos".

O tipo de domicílio parece favorecer um certo tipo de comportamento da população em relação aos cães. Beck (1973), comenta que em Baltimore, Estados Unidos, início da década de 70, a maioria dos domicílios eram construções de 1 ou dois pavimentos, permitindo o acesso direto dos seus ocupantes às ruas. Era comum, nos princípios de manhã e finais de tarde, a observação de portões abertos e os cães tendo livre acesso às ruas. Os muros, a maioria baixos, e algumas grades com falhas, permitiam que os cães fugissem temporariamente ao saltassem sobre estes.

Segundo Beck (1973), a presença de cães soltos está muito correlacionada às áreas de baixo poder aquisitivo e elevadas densidades populacionais. Este autor cita que observações de campo, entrevistas com autoridades e com a população, sugerem que o aumento da densidade canina está relacionado ao lixo disponível, portões abertos, áreas desocupadas que servem como abrigos para os animais e também está ligada à criminalidade. A maior criminalidade encoraja a criação de cães; o lixo disponível atrai e fornece alimentação aos cães errantes; mais portões abertos significam liberdade de movimentos para os cães de estimação. O acúmulo de lixo está associado a um aumento na atividade dos cães. Em áreas de melhor poder aquisitivo, também se observava um aumento na criação de cães, mas nessas áreas os 
proprietários mantinham os seus cães em quintais fechados, ou dispunham de mais tempo para caminhar com os animais.

Retornando à cidade de Recife, a criação de cães mostrou-se difundida em todas as áreas da cidade, independente de status econômico ou cultural. Inúmeros domicílios que não criavam cães por ocasião da entrevista, no passado, já haviam tido esses animais. Enquanto umas pessoas deixam de criar cães, outras começam a criar, e as "entradas" e "saídas" de cães nos domicílios da população asseguram uma certa estabilidade do tamanho da população canina.

Por outro lado, aspectos econômicos e culturais estão associados às atitudes das pessoas em relação aos cães, como será discutido a seguir.

\subsection{Características diferenciais entre as Unidades Primárias de Amostragem}

No presente estudo, verificou-se que fatores como densidade, tipo e proteção do domicílio, instrução, renda per capita familiar, lixo, presença de pessoas de um grupo etário específico, dentre outros, parecem influenciar determinados aspectos da população canina e o comportamento das pessoas em relação aos cães.

\subsubsection{Criação de cães:}

A criação de cães em Recife está associada ao tipo de domicílio e à presença de pessoas jovens no domicílio, com idade entre 11 e 17 anos. Quanto maior a freqüência de domicílios do tipo casa (térreo com um ou mais pavimentos) em um setor, maior a freqüência de domicílios com cães. Do mesmo modo, quanto maior a freqüência de jovens entre 11 e 17 anos, maior a freqüência de domicílios com cães.

Não há muitos relatos detalhados desta natureza na literatura, mas Beck (1973) sugere a existência de uma relação entre o tipo de domicílio e a criação de cães, como já foi citado anteriormente. 
Franti et al. (1974) verificaram uma associação entre o tipo de domicílio individual e a criação de cães na Califórnia. Estes autores também observaram que os domicílios que tinham animais de estimação apresentavam uma maior quantidade de pessoas com idades entre 5 e 14 anos, maior número de cômodos, além de maior renda per capita familiar.

No Senegal, Akakpo et al. (1990) observaram que os cães são geralmente criados por jovens e adolescentes.

\subsubsection{Abundância de "cães de rua"}

Três variáveis diferenciam melhor os setores estudados quanto à abundância de cães de rua (cães soltos na localidade): instrução dos chefes de família, freqüência de colheita de lixo e renda per capita familiar.

Maiores freqüências de domicílios com renda per capita familiar elevada, e com chefes possuindo elevados níveis de instrução, estão relacionadas a menor abundância de cães de rua. A freqüência de domicílios com colheita de lixo deficiente está relacionada à abundância dos referidos cães.

Possíveis explicações para esses achados já foram citadas anteriormente. As variáveis renda e instrução são variáveis correlacionadas positivamente, e níveis de instrução e renda estão relacionados diretamente à freqüência de colheita de lixo no local, além de melhores condições para restrição dos animais. Some-se a este aspecto, o fato de que áreas ricas tendem a possuir maior quantidade de domicílios do tipo apartamento, onde a criação de cães tende a ser menos comum, e a restrição dos animais maior.

Quando o tipo de cão de rua envolvido são os cães de vizinhança (seus domicílios são conhecidos e estão localizados nas proximidades dos domicílios entrevistados), as variáveis área per capita familiar, renda per capita familiar e saneamento passam a explicar melhor as diferenças entre os setores estudados. A variável área per capita familiar está correlacionada positivamente com a variável renda. Os setores mais pobres são pior servidos pelo serviço de saneamento e possuem menor área domiciliar disponível. 
Fora os aspectos já discutidos, a pequena área do domicílio e a relativamente elevada densidade de pessoas e animais no local podem favorecer o hábito de deixar os animais terem acesso freqüente às ruas, como uma forma de "aliviar" a escassez de espaço. Além do mais, nas áreas pobres, com suas ruas estreitas e domicílios próximos, tende a existir um ambiente de "familiaridade", onde a rua, nas proximidades dos domicílios, parece ser uma extensão da própria residência. Nestes lugares, a figura do cão solto, mas conhecido da vizinhança, será comum.

Nas áreas ricas, onde a freqüência de cães restritos seria maior, e a residência em apartamentos comum, os cães soltos tenderiam a ser desconhecidos dos entrevistados, e nas áreas de renda baixa, o relato de cães de vizinhança soltos tenderia a aumentar.

As condições que favorecem a abundância de cães errantes se concentram nas áreas pobres da cidade, não sendo fácil apontar a causa primária do fenômeno. Provavelmente, existe uma complexa interação entre os diferentes aspectos culturais, econômicos e sociais, resultando numa realidade particular a uma época da cidade de Recife

\subsubsection{Prevalência de cães dependentes e de cães restritos}

Na cidade de Recife, aproximadamente $40 \%$ dos cães com domicílio de referência são animais semi-restritos ou não restritos, o que aponta para um expressivo número de animais com livre acesso ao ambiente extra-domiciliar, sem supervisão do proprietário, ao menos em alguns momentos do dia.

Neste trabalho, o termo restrição é empregado em relação à movimentação do cão, sendo excluída por exemplo, a restrição da atividade reprodutiva imposta intencionalmente pelos donos, muito embora a restrição de movimento implique em restrições da atividade reprodutiva.

A maioria dos cães são totalmente dependentes de seus proprietários, mas $26,7 \%$ são apenas parcialmente dependentes, uma vez que parte de suas necessidades não são satisfeitas pelos donos. 
Instrução e renda são os fatores que melhor explicam os níveis de dependência dos cães, estando estas variáveis correlacionadas positivamente. Já a restrição dos cães, é melhor explicada pela proteção dos domicílios. Os maiores níveis de restrição são observados nas áreas cujos domicilios apresentam melhores condições físicas de restringir os cães, como a existência de muro, grades e / ou portões, sem falhas.

Em relação a estes aspectos, cabem as observações feitas sobre a criação de cães e a abundância de animais soltos.

Em muitos domicílios em geral criam-se cães. Entretanto, famílias pobres, além de viverem em domicílios desprotegidos e localizados em áreas inseguras, têm poucas condições de atender às necessidades básicas dos cães que criam, por limitações econômicas. E por residirem, geralmente, em domicílios pequenos, de construção inacabada e sem proteção adequada, favorecem o acesso dos cães ao ambiente extra domiciliar. Na rua, esses cães realizam suas necessidades básicas e eventualmente podem buscar complementar a sua alimentação.

Por outro lado, o hábito de liberar os cães na rua, embora freqüente em certas áreas da cidade, não é exclusividade das áreas pobres, existindo praticamente em todos os lugares, o que indica permissividade das pessoas e das autoridades.

Não obstante existir uma legislação específica para animais e controle de zoonoses na cidade de Recife (Recife, 1995), esta não é fielmente observada.

Comportamento semelhante em relação aos cuidados com os cães foi verificado no Equador (Beran e Frith, 1988). Em áreas de classe alta, a maioria dos cães, freqüentemente cães de raça, era mantida restrita a maior parte do tempo. Em áreas de classe média, os cães eram mantidos presos enquanto os donos trabalhavam, mas eram soltos nos inícios de manhã e finais de tarde, e eventualmente à noite. Nas áreas de classe baixa, os cães de guarda eram confinados durante a noite, mas tinham liberdade de perambular durante o dia.

Uma observação importante emerge a partir desses achados. Embora altas densidades caninas (tendo a área como referência) sejam notadas em setores de baixo status econômico (que possuem menor área domiciliar per capita), o que é ainda mais perceptível devido à abundância de cães nas ruas, devemos notar que elevados números de cães por habitante, tendem a ser encontradas em setores de renda 
superior, dado que os setores em comparação tenham distribuições semelhantes de tipos de domicílios.

\subsubsection{Cães vacinados contra raiva}

Os setores com maior prevalência de cães vacinados contra raiva se diferenciam daqueles setores com menor prevalência de cães vacinados, por apresentarem maior proporção de domicílios com renda per capita familiar acima da mediana.

A variável renda per capita familiar está correlacionada a inúmeras outras variáveis, e a explicação para este achado pode ser resultado de interações entre diversos fatores, que vão de aspectos culturais a eventuais problemas de acesso ao serviço de vacinação anti-rábica.

Já na avaliação da campanha de vacinação realizada em 1993 (relatório enviado à Diretoria de Epidemiologia e Vigilância Sanitária do Estado), constatou-se problemas de distribuição dos postos de vacinação, e divulgação desigual da campanha em diferentes setores da cidade. Aspectos dos mesmos serão apresentados a seguir:

\footnotetext{
"Distância das residências dos animais aos postos de vacinação:
}

$41,3 \%$ dos entrevistados caminharam 1 quarteirão até $\circ$ posto de vacinação; $29,1 \%$ caminharam 2 quarteirões; $16 \%$ caminharam 3 quarteirões; 7,8\% caminharam 4 quarteirões; $3,2 \%$ caminharam 5 quarteirões; e 2,6\% caminharam 6 ou mais quarteirões. $\mathrm{O}$ maior número de pessoas se concentra numa menor distância dos postos, e vai decrescendo à medida em que aumenta a distância dos postos até as suas residências.

Tais números podem ser explicados de diferentes maneiras: As pessoas que moram mais distante dos postos levariam menos seus animais para vacinar; ou os postos seriam tão numerosos e tão bem distribuídos na cidade que a grande maioria das pessoas não precisariam caminhar mais que dois quarteirões até o posto de vacinação mais próximo. Considerando a provável distribuição radial das residências em relação aos postos, a primeira situação parece ser a mais provável." 
Reforçando a hipótese acima, verificou-se grande heterogeneidade no número de animais vacinados nos postos de diferentes áreas da cidade. Considerando que as áreas pobres freqüentemente estão situadas em locais de acesso dificultado, e que a pessoas residentes nestas áreas têm dificuldades para se deslocarem com seus animais nos dias de campanha, em parte por questões econômicas, é razoável supor que as pessoas que moram em áreas pobres tenham limitado acesso ao serviço de vacinação.

Eng et al. (1993) citam que a maioria dos donos de cães não vacinados em Hermosillo, México, desejavam que seus cães fossem vacinados, mas $13 \%$ deles não podiam levar seus animais às clínicas de vacinação, e portanto, não podiam ser atingidos pelos programas de vacinação baseados em clínicas.

No caso de Recife, aproximadamente $7 \%$ dos entrevistados disseram não vacinar os cães por eles serem bravos, o que dificultava o transporte dos mesmos até os postos de vacinação. Nos postos, constatou-se que muitas pessoas vinham solicitar doses de vacina para vacinar os seus animais em casa, por serem estes animais muito bravos. Algumas vezes, presenciamos os vacinadores se deslocando para vacinar os animais em casa a pedido dos seus donos.

A questão da divulgação da campanha de vacinação anti-rábica, também deve ser considerada. Através de avaliaçð̃es realizadas em 1993, verificou-se que a TV é o principal meio de comunicação através do qual a maioria das pessoas dos diferentes setores tomam conhecimento da campanha de vacinação anti-rábica anual. A tomada de conhecimento da campanha através de outros meios, principalmente os meios escritos, é mais restrita a certos setores da sociedade.

A divulgação mais intensa da campanha, através da TV, só ocorre em um dia, o dia nacional da vacinação anti-rábica, não existindo uma efetiva publicidade local. Através de entrevistas, se constatou que muitas pessoas só tomaram conhecimento da vacinação anti-rábica no dia da campanha, após o início das atividades da mesma, geralmente o fazendo através de outras pessoas ou ao verem pessoas e animais se deslocando até os postos.

Mas como a vacinação anti-rábica em Recife, nos últimos anos, foi realizada em mais de um dia, em fins de semana consecutivos, é provável que uma parcela da 
população, sobretudo a que tem acesso mais limitado a meios de comunicação que não sejam a TV, fiquem parcialmente informadas.

Um outro aspecto a considerar, são os cuidados dispensados aos cães segundo a raça dos mesmos. Beran e Frith (1988) citam que em domicílios de classe alta em Guayaquil, Equador, onde havia maior proporção de cães de raça, estes animais geralmente eram vacinados por iniciativa dos proprietários.

Possivelmente, em áreas ricas, onde os animais de raça são mais numerosos, exista maior empenho dos proprietários em vacinar os animais, não só em campanhas, mas também em clínicas particulares.

\subsection{População canina}

\subsubsection{Tamanho e densidade}

Comparativamente aos achados de Recife, Franti et al. (1974) e Eng et al. (1993), citam maior proporção de domicílios com cão, na Califórnia, Estados Unidos, e em Hermosillo, México, onde aproximadamente $50 \%$ e $47 \%$ dos domicílios criam cães, respectivamente. Valores ligeiramente superiores aos de Recife foram encontrados em áreas urbanas da Nigéria, existindo 38,2\% de domicílios com cão $(32,4$ a $44 \%$ ), com uma média de 0,5 cães por domicílio (Oboegbulem e Nwakonobi, 1989). Em áreas urbanas das Filipinas, encontrou-se maior média de cães por domicílio, igual a 0,612 (Beran et al., 1972).

Os resultados na amostra indicam, para a cidade de Recife, uma quantidade de cães ligeiramente maior do que a quantidade estimada pelos serviços de controle de zoonoses, baseada no indicador oficial de 1:10, resultando em um valor $9,35 \%$ maior que o oficial. Muitos técnicos dizem ser este indicador de 1:10 a "estimativa da Organização Mundial de Saúde". Entretanto, como já foi citado anteriormente no presente trabalho, indicações recentes da OMS sugerem a substituição deste indicador geral, mediante a realização de estudos regionais. 
A estimativa da população canina de Recife difere substancialmente da estimativa realizada por Nunes et al. (1997) em Araçatuba, cidade com 146.000 habitantes na região Noroeste do Estado de São Paulo, onde se estimou um cão para cada 3,57 habitantes $(1: 3,57$ ou $2,8: 10)$.

Em Recife, a quantidade de cães para cada habitante é bastante inferior àquela descrita para Manhattan, Estados Unidos (Nassar e Mosier, 1980). Valores mais próximos aos de Recife, foram encontrados em Guayaquil, no Equador (Beran e Frith, 1988), no México (Eng et al., 1993), e em Dumaguete, nas Filipinas (Beran et al. (1972), sendo, respectivamente 1:7,2 (entre 1:5,8 e 1:11), 1:8 e 1:11,2, expressos em cão : habitantes. Já em áreas urbanas da Nigéria, Oboegbulem e Nwakonobi (1989) citam a razão de um cão para 21 pessoas (entre 1:17 e 1:26).

Considerando as densidades caninas mínimas capazes de manter o vírus rábico (Cleaveland e Dye, 1995), os valores encontrados em diferentes áreas de Recife, variando entre 204 cães $/ \mathrm{km}^{2}$ e 1.324 cães $/ \mathrm{km}^{2}$ (em média 522 cães $/ \mathrm{km}$ ${ }^{2}$ ), são elevados o bastante para suportar a manutenção do vírus rábico, desde que a fração de suscetíveis nesta população possibilite a existência de elevadas densidades de suscetíveis.

Embora apresentando densidades caninas inferiores àquelas do Equador (Beran e Frith, 1988), Recife possui densidades caninas maiores do que as citadas na Nigéria (Oboegbulem e Nwakonobi, 1989), onde há relatos de que a incidência de raiva varia com a densidade de cães.

\subsubsection{Origem dos cães}

Em Guayaquil, Equador, $72 \%$ dos cães foram recebidos como presentes e apenas 3,2\% foram adotados da rua (Beran e Frith, 1988), o que indica um comportamento semelhante à cidade de Recife.

A maioria dos cães de Recife foram presenteados (62,2\%), vindo em seguida as crias nascidas em casa e que foram mantidas, os cães comprados e os cães achados na rua. Esses dados indicam a forma utilizada pela população em geral para dar destino aos animais nascidos em casa, a maioria das vezes de forma não programada. 
À medida em que a ninhada vai crescendo, vai se tornando mais dispendiosa e exige cada vez mais tempo para cuidados e limpeza, e a maneira mais rápida e fácil de dar destino aos cães é presenteá-los a pessoas conhecidas ou relacionadas a estas. Os quase $10 \%$ de cães achados na rua revelam um outro hábito de parte da população abandonar os seus cães na rua, geralmente crias para as quais não acharam destino, e algumas vezes por motivo de doença ou mesmo mudança de domicílio.

Por outro lado, uma fração dos cães de Recife $(8,3 \%)$ são procedentes de outras cidades onde nasceram, a maioria delas situadas na Região Metropolitana de Recife, onde a raiva é endêmica. Isto implica em considerações importantes na escolha de estratégias integradas de controle da raiva em regiões metropolitanas.

\subsubsection{Distribuição quanto ao sexo}

A razão entre sexos ao nascer é igual a 1 para 1 , mas inúmeros trabalhos indicam predominância de cães do sexo masculino, variando a razão fêmeas : machos mais comumente entre 1:1,7 e 1:3 (WHO, 1987). As atitudes da população em geral resultam numa seleção dos cães na população.

Em Recife, observou-se uma maioria de cães do sexo masculino (61\%) ou 1 fêmea : 1,56 machos, à semelhança de achados em outras localidades: Beran e Frith (1988) estimaram $61 \%$ de machos em Guayaquil, Equador ; No Senegal, Akakpo et al. (1990) citam 65,76\% de machos ; Malaga et al. (1976), em Lima, Peru, citam $71 \%$ de machos. No caso de Lima, mais de $50 \%$ das fêmeas são eliminadas logo ao nascer.

Não se verificou evidências de ações para a eliminação de fêmeas como é citado no Peru, e as diferenças entre sexos provavelmente ocorrem devido à maior preferência da população, levando a uma maior chance de sobrevivência de machos.

Contrastando com a maioria dos relatos na literatura, Oboegbulem e Nwakonobi (1989) estimaram $48 \%$ de machos (1 fêmea : 0,9 machos) em áreas urbanas da Nigéria, e uma proporção de machos ainda menor em áreas rurais. 


\subsubsection{Raças de cães}

As raças de cães mais criadas em Recife refletem as finalidades desses animais para a população: uma maioria de raças pequenas e geralmente dóceis, de estimação e companhia, seguida por raças de maior porte utilizadas para guarda ou com dupla finalidade, guarda e estimação.

Beran e Frith (1988) encontraram em Guayaquil, Equador, 17,6 \% cães de raça, existindo diferentes proporções de cães de raça segundo a classe socioeconômica (52,1 \% em domicílios de classe alta, 19,3 \% na classe média e 10,1 $\%$ na classe baixa). À semelhança de Recife, aproximadamente $60 \%$ cães eram SRD (cruzamentos indeterminados).

Oboegbulem e Nwakonobi (1989) descrevem resultados diferentes em áreas urbanas da Nigéria, sendo $34 \%$ raças nativas e $49 \%$ raças exóticas. A maioria dos cães eram de grande porte, sendo as raças adequadas à finalidade predominante de guarda.

\subsubsection{Finalidade dos cães}

Em torno de $66 \%$ dos cães de Recife são cães de estimação e companhia, e aproximadamente três em cada dez cães são criados com finalidade de guarda ou guarda e estimação.

Contrastando com os resultados de Recife, em Guayaquil, Equador, aproximadamente $70 \%$ dos cães foram classificados como cães de guarda, e em torno de $18 \%$ como animais de estimação (Beran e Frith, 1988). Beran et al. (1972) também citam uma maioria de cães de guarda na Filipinas. Oboegbulem e Nwakonobi (1989) descrevem uma maioria de cães de guarda na Nigéria (45\% da população canina), em relação às outras finalidade. Na Nigéria, apenas $30 \%$ dos cães eram mantidos como animais de estimação. Estes últimos autores citam que a insegurança fez aumentar a criação de cães de guarda naquele país. 


\subsubsection{Natalidade e mortalidade}

Pelos resultados, constata-se que o controle reprodutivo é muito pouco utilizado pelos proprietários de cães de Recife. Além do mais, os níveis limitados de restrição total favorecem a falta de controle da reprodução dos cães. Na região metropolitana de Recife, é relativamente fácil presenciar cães acasalando nas ruas (Figura 27).

Figura 27: Cães acasalando livremente na rua, em município da Região Metropolitana de Recife.

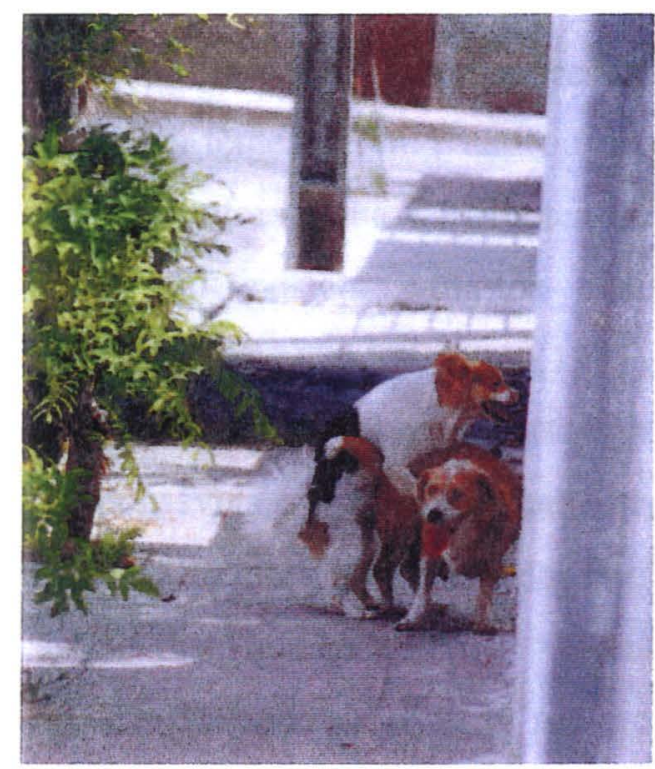

Os coeficientes de fecundidade, apesar de pequenas diferenças, foram elevados em todos os grupos etários estudados. Os baixos níveis de controle da população canina ajudam a confirmar os elevados coeficientes de natalidade e de fecundidade, e indicam que esta população tem plena capacidade de fornecimento rápido e contínuo de novos indivíduos, assegurando, ao menos, a reposição dos indivíduos que são removidos por quaisquer causas, inclusive através de práticas oficiais de controle da população animal. 
Nassar e Mosier (1980) apresentam uma situação muito diferente no Estados Unidos, onde $66,66 \%$ de fềmeas eram ovariectomizadas. A reprodução era muito pouco freqüente em fêmeas a partir de 5 anos de idade. Em função da taxa reprodutiva muito baixa, a estabilidade no tamanho da população canina na cidade era mantida graças a uma elevada introdução de animais oriundos de outras localidades, estimando-se $57 \%$ de imigração.

No Peru, Malaga et al. (1979) encontraram freqüências de partos em cadelas semelhantes às de Recife. Em torno de $71 \%$ das cadelas não tiveram cria em um ano, $25 \%$ tiveram uma cria e $4 \%$ tiveram duas crias. O tamanho das ninhadas também foi semelhante, em média 5,4 filhotes por cria.

Beran e Frith (1988) também descrevem resultados similares, em Guayaquil, Equador, onde $63,6 \%$ das fềmeas com 1 ano ou mais nunca tinham tido cria. $\mathrm{O}$ tamanho médio das ninhadas foi igual a 4,1 filhotes vivos, com 5,8\% de natimortos.

Aparentemente, não existem muitos dados sobre a mortalidade em populações caninas. Nos Estados Unidos, Beck (1975) cita que aproximadamente 12 $\%$ da população canina estimada daquele país é destruída a cada ano. Lá, os automóveis foram responsáveis por aproximadamente $10 \%$ da mortalidade canina. Este autor comenta que a alta mortalidade, em populações com crescimento positivo, implica em redução na distribuição etária. Corroborando com esta afirmação, observou-se que a média de idade de cães de rua era de 2,3 anos, enquanto que a média de idade de cães domiciliados era de 4,4 anos. A maioria dos cães jovens são não imunes, e também são mais suscetíveis às infecções e doenças parasitárias.

A partir dos dados obtidos no estudo da mortalidade dos cães de Recife, e considerando o exposto até o momento, podemos afirmar que:

As taxas de mortalidade são muito elevadas em todas as idades, destacandose entretanto, entre animais filhotes e jovens. Esta mortalidade, juntamente com a natalidade, condicionam uma estrutura etária onde predominam os animais jovens, em uma população com expectativa de vida relativamente reduzida.

As principais causas presumidas de mortalidade, provavelmente são conseqüência direta ou indireta dos baixos níveis de cuidados, supervisão e restrição a que os animais são submetidos, em especial: 
(1) a falta de imunizações, que podem prevenir as principais doenças como viroses e bacterioses, que causam mortalidade em cães, sendo muito comuns aquelas que provocam gastroenterites, como a Parvovirose, Adenovirose, Cinomose, Coronavirose e Leptospirose (Corrêa e Corrêa, 1992); e também a falta de vermifugações periódicas.

(2) a falta de restrição dos cães, favorecendo o contato entre estes e a transmissão de doenças infecciosas; aumentando a chance de exposição dos cães a substâncias tóxicas e letais, em especial os raticidas utilizados extensivamente em terrenos baldios e outros lugares nos grandes centros urbanos; e finalmente, que aumenta as chances de acidentes de trânsito envolvendo os animais;

(3) Alimentação inadequada dos cães, possivelmente por falta de recursos ou por falta de informações, favorecendo a mortalidade por causas infecciosas e parasitárias, bem como estimulando os animais a deixarem o domicílio em busca de alimento;

(4) Falta de assistência veterinária, pelos motivos citados no item anterior, favorecendo a mortalidade pela falta de prevenção de enfermidades ou tratamento adequado das mesmas, além da falta de orientação adequada para os cuidados com os animais.

Elevadas taxas de mortalidade favorecem a renovação populacional, sobretudo se considerarmos que há uma tendência à substituição do animal morto na população. A renovação torna mais jovem a população canina, que por isso tende a ser mais prolífica.

Em relação ao problema da raiva, parte dos animais que morrem era imune à doença, em conseqüência de vacinações anti-rábicas a que foram submetidos. Além do mais, estes animais tendem a apresentar resposta mais rápida, mais intensa e mais duradoura a revacinações, devido à memória imunológica. Já os animais que nascem, em termos práticos, podem ser considerados todos não imunes à raiva, pois 
ao nascer nunca apresentam títulos acima dos limiares mínimos requeridos. A imunidade materna, se existente, logo desaparece.

A estimativa do coeficiente geral de mortalidade aponta para a mortalidade de mais de um quarto da população no período de um ano, valor este que se aproxima daquele observado para a proporção de animais primovacinados em campanha de vacinação anti-rábica anual, e também tende a ser próximo da mortalidade esperada no período de um ano, para uma população com expectativa de vida inferior a 4 anos, conforme foi estimado no estudo.

Assim, as elevadas taxas de mortalidade, associadas às elevadas taxas de natalidade, tendem a originar fatores antagônicos ao controle da raiva, e favoráveis à manutenção e disseminação do vírus rábico.

\subsubsection{Estrutura etária}

A comparação de dados do estudo, com citações da literatura revisada, permite a realização de algumas observações.

Nos Estados Unidos, em Manhattan, Nassar e Mosier (1980) estimaram que apenas $15,9 \%$ dos animais tinha menos de 1 ano, enquanto que $42,6 \%$ tinham menos de três anos. Os animais com idade entre 1-3 anos correspondiam a 26,7\%; $22 \%$ tinham entre 3 e 5 anos; 10,9\% tinham de 5 a 7 anos; e $24,5 \%$ tinham de 7 a 16 anos. Lá portanto, a população possui maior expectativa de vida média, e tende a existir menos animais jovens.

No Equador e no México, os animais apresentaram menor idade média, apontando para uma situação ecológica mais desfavorável, em relação à cidade de Recife. Beran e Frith (1988) estimaram uma expectativa de vida média dos cães de 2,5 anos, em Guayaquil; $32 \%$ dos animais tinham menos de um ano de idade, sendo que $14 \%$ dos cães tinham menos de 3 meses, e $18 \%$ tinham idade entre 3 e 11 meses. Em Hermosillo, no México, a idade mediana dos cães era de 2 anos, com 8 $\%$ dos animais tendo idade inferior a três meses e $27 \%$ menos de um ano (Eng et al., 1993). 
Uma população canina ainda mais jovem foi encontrada na Nigéria (Oboegbulem e Nwakonobi, 1989), onde $57 \%$ dos cães de áreas urbanas tinham menos de 1 ano, $32 \%$ tinham entre um e cinco anos, e $11 \%$ mais de cinco anos. A idade média dos cães era de 2 anos.

Akakpo et al. (1990) também descrevem uma população canina relativamente jovem no Senegal, o que foi considerado uma conseqüência da rápida renovação populacional. Estes autores comentam que a falta de uso de medicamentos não permite aos cães sobreviverem às agressões microbianas e parasitárias, e para eles, 0 tipo de criação dos cães reflete a pobreza dos seus proprietários. Os cães geralmente pertencem a jovens e adolescentes, que não têm condições de fornecer alimentação, nem tratamento, aos animais que adoecem.

Ao analisarmos a estrutura etária da população canina de Recife, cuja população canina é predominantemente jovem, e ao associarmos esses aspectos com os achados de elevadas taxas de natalidade e mortalidade, bem como aspectos do perfil social e econômico da população recifense, podemos supor que a qualidade de vida da população humana tende a influenciar, além dos cuidados gerais com os cães, a natalidade e a mortalidade na população canina, e em conseqüência, a sua estrutura etária.

Esta evidência torna-se mais perceptível através do exame da Tabela 21, adaptada de Wandeler et al. (1988), os quais destacam importantes aspectos relativos à estrutura etária das populações caninas. Nesta, são comparadas as estruturas etárias de populações caninas de países mais desenvolvidos economicamente (Estados Unidos e Suíça), com aquelas de países mais pobres (Sri Lanka, Tunísia, Equador e Brasil). Às informações dos citados autores, foram acrescentados dados de Recife e também de alguns outros trabalhos. 
Tabela 21: composição de grupos etários de cães com proprietários em diferentes áreas geográficas

\begin{tabular}{|c|c|c|c|c|c|c|}
\hline \multirow[b]{2}{*}{ Local } & \multicolumn{6}{|c|}{$\begin{array}{c}\text { Percentual da população canina nos } \\
\text { grupos etários indicados }\end{array}$} \\
\hline & 0|-1 & $1 /-3$ & $3 \mid-5$ & $5 \mid-7$ & 7F- & Referência \\
\hline OHIO, EUA & 19 & 25 & 19 & 12 & 25 & *** \\
\hline CALIFÓRNIA, EUA & 13 & 25 & 22 & 16 & 24 & ** \\
\hline BERNA, SUIÇA & 8 & 20 & 17 & 17 & 34 & $* *$ \\
\hline GALLE, SRI LANKA & 24 & 28 & 21 & 14 & 13 & ** \\
\hline EL KEF, TUNISIA & 36 & 34 & 16 & 9 & 5 & $* *$ \\
\hline GUAYAQUIL, EQUADOR & 31 & 32 & 19 & 9 & 9 & $* *$ \\
\hline RECIFE, PE / BRASIL (1995) ** & 24 & 30 & 19 & 13 & 14 & Tese \\
\hline RECIFE, PE / BRASIL (1996) & 31 & 23,5 & 17 & 12 & 16,5 & Tese \\
\hline MANHATTAN, EUA (1980) & 15,9 & 26,7 & 22 & 10,9 & 24,5 & (A) \\
\hline ARAÇATUBA, SP / BRASIL (1994) & 20,2 & $\mid--56,6$ & -1 & $1--2$ & $2-1$ & (B) \\
\hline HERMOSILLO, MÉXICO (1993) & 27 & H........ & -73 & $\ldots$ & $-\infty$ & (C) \\
\hline NIGÉRIA (1989) & 57 & $\mid--32-$ & -1 & $\mid-1$ & $---\mid$ & (D) \\
\hline
\end{tabular}

\footnotetext{
* Animais vacinados em campanha: animais com menos de um ano, em particular filhotes, e animais velhos, possivelmente foram subestimados, por apresentarem menor probabilidade de comparecerem à vacinação em campanha. ** Tabela adaptada de: Wandeler et al. (1988), com a inclusão de dados de Recife / PE, seguida de outras localidade com referência citada.

(A) Nassar e Mosier (1980); Nunes et al. (1997); (C) Eng et al. (1993); (D) Oboegbulem e Nwakonobi (1989).
}

Observa-se que nos países desenvolvidos, os grupos etários mais velhos têm uma participação relativa maior na população canina, comparativamente aos países não desenvolvidos economicamente, onde os cães jovens, principalmente cães com menos de um ano de idade, são o grupo predominante. Nota-se em Recife, contudo, que o grupo etário de animais com idade a partir de 7 anos já é relativamente numeroso, embora os grupos etários com idades inferiores a 3 anos ainda tenham a maior participação relativa. Talvez este comportamento reflita uma tendência de redução nas taxas de mortalidade em animais que já atingiram uma certa faixa etária, a partir da qual aumentariam as chances de sobrevivência (melhoria na assistência), ainda não acompanhada de uma redução nas taxas de natalidade (controle reprodutivo inalterado), e também de mortalidade entre cães jovens. 
No caso de Recife, verificou-se que a renda per capita familiar mediana nos setores censitários (unidades primárias de amostragem) está correlacionada negativamente com a proporção de cães com menos de um ano de idade no setor $\left(r_{s}\right.$ $=-0,49 ; \mathrm{P}<0,01)$ e está correlacionada positivamente com a idade mediana dos cães no setor $\left(r_{s}=0,40 ; P<0,05\right)$.

Os resultados são sugestivos de que parece haver uma tendência de aumento da idade média da população canina à medida que aumenta o status socioeconômico da localidade, possivelmente condicionando a estrutura etária da população canina.

\subsection{Campanha de vacinação anti-rábica}

Ao se analisar o conteúdo do relatório de avaliação da campanha de vacinação anti-rábica de Recife em 1995 (Anexo IV), verifica-se que muitos problemas parecem ser conseqüência da insuficiência de recursos necessários à organização e execução das atividades de campanha. E neste caso, a menos que a causa do problema seja removida, não haverá solução definitiva.

Por outro lado, percebe-se que muito pode ser melhorado, mesmo nas atuais condições existentes. O planejamento das atividades, e o treinamento do pessoal envolvido na campanha, ocupam posição central. $O$ registro $e$ análise das experiências de campanha, com o adequado aproveitamento das informações nas futuras etapas de planejamento, o que aparentemente não está ocorrendo em Recife, certamente trariam ganhos substanciais.

Merece registro destacado, o manuseio inadequado das vacinas anti-rábicas pelos vacinadores, nos dias de campanha, pois este fator pode estar relacionado à ineficiência da imunização anti-rábica, embora não seja possível mensurar a extensão desses efeitos com os dados disponíveis. Este achado entretanto, não exclui a possibilidade de outros elementos estarem associados aos baixos níveis de imunidade contra raiva observados na população canina de Recife.

Inicialmente, trabalhava-se com a hipótese de que uma das explicações para o problema da raiva em Recife eram as supostas superestimadas coberturas de 
vacinação. Esta afirmação se baseava na possibilidade de a população canina de Recife ser muito maior do que a estimativa oficial, implicando em superestimação das coberturas oficiais. Existiria assim, uma elevada proporção de animais suscetíveis, por falta de cobertura de vacinação.

Combinando os intervalos de confiança para média de pessoas por domicílio, e média de cães por domicílio em geral, observaremos que os respectivos limites superiores e inferiores da razão habitantes : cães não diferem significativamente da estimativa oficial de 1 cão para 10 habitantes. Estes irão variar entre 1 cão : 8,21 habitantes e 1 cão : 12,45 habitantes. É provável que haja elevada quantidade de cães por habitantes em algumas áreas da cidade, mas não o bastante para justificar uma grande discrepância nos índices oficiais de cobertura de vacinação.

Entretanto, a estimativa do tamanho da população canina de Recife, realizada no presente trabalho, pode trazer implicações para a avaliação das atividades de controle da raiva, particularmente as coberturas das campanhas de vacinação antirábica, tanto no município como nos distritos sanitários.

Se considerarmos a razão de um cão para 9,17 habitantes, as coberturas oficiais de vacinação passam a ser superestimadas. A Figura 28 ilustra este aspecto. Esta superestimação será ainda maior se forem considerados valores totais de cobertura de vacinação, incluindo também a população de gatos. 
Figura 28: cobertura de vacinação anti-rábica e eliminação de cães errantes na cidade de Recife, no período de 1987 a 1997.

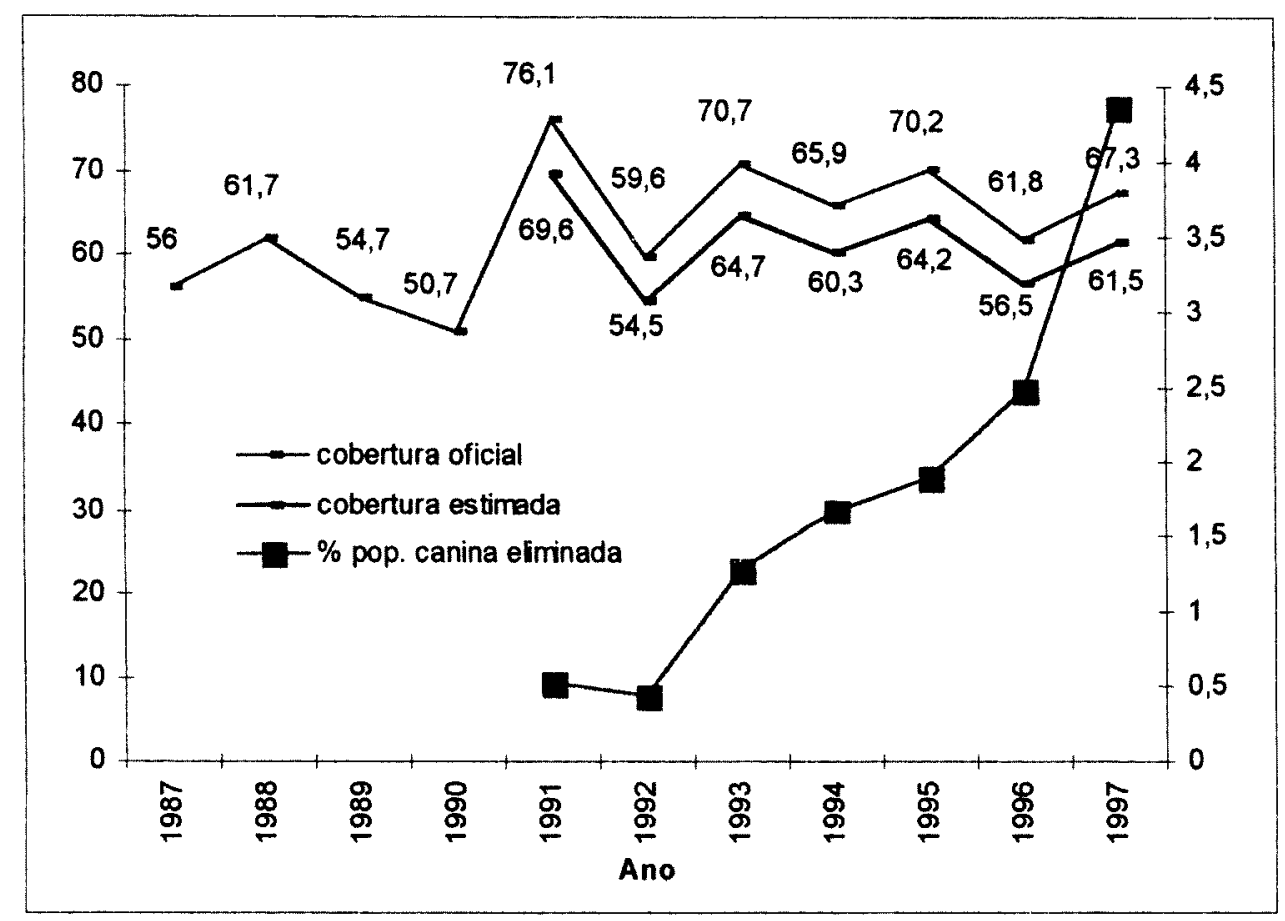

Os novos valores estimados indicam uma média de 61,6\% de cobertura de vacinação anti-rábica nos últimos sete anos (64\% em 1995). Considerando também a elevada renovação populacional e a rápida perda de imunidade em primovacinados (Eng et al., 1994), nos aproximaremos dos resultados da sorologia, que indicam apenas $32 \%$ de animais com boa resposta (títulos $\geq 0,5 \mathrm{UI} / \mathrm{ml}$ ), num período de 4 a 6 meses após a realização da campanha de vacinação de 1995.

Um achado que permite avaliar melhor o novo indicador para a população canina de Recife são os dados de cobertura de vacinação anti-rábica estimados no presente trabalho, os quais se basearam em relatos dos proprietários de cães da amostra de domicílios. No início do ano de 1996 , considerando $74,3 \%$ de cães vacinados contra raiva, menos $3,8 \%$ de animais com vacina vencida, dos quais 82,2 \% teriam sido vacinados na campanha de vacinação anti-rábica de 1995, teremos uma cobertura de vacinação em campanha de aproximadamente $58 \%$. 
Este valor se aproxima das novas coberturas estimadas, sendo inferiores aos dados oficiais. Ainda deve ser acrescentado o fato de que o denominador que foi utilizado para as estimativas oficiais de Recife se basearam num valor constante, considerando, para todos os anos, a razão de 1 cão para 10 habitantes, aplicado ao tamanho da população humana do último censo demográfico que precedeu a campanha, sem considerar taxas de crescimento populacional. Isto tende a aumentar ainda mais a superestimação das coberturas oficiais de vacinação, principalmente à medida em que o ano avaliado se distancia do último censo.

As novas coberturas de vacinação, por terem sido calculadas indiretamente, a partir dos valores oficiais das coberturas de vacinação - considerando uma taxa anual de crescimento populacional publicada pelo IBGE (IBGE, 1991) - ainda tendem a estar ligeiramente superestimadas, pois partem de valores possivelmente superestimados.

Sem considerar o mérito deste novo indicador para o tamanho das populações canina e felina de Recife, é possível que a adoção de valores mais conservadores (admitir maior tamanho da população animal) traga benefícios ao controle local da raiva, uma vez que as avaliações dos programas de controle da raiva não seriam superestimadas.

Nota-se ainda, na Figura 28, que os níveis de cobertura de vacinação têm se mantido relativamente constantes, ao passo que ocorreu importante aumento nas capturas e eliminação de cães errantes. Isto parece indicar um menor empenho no sentido de melhorar as estratégias de vacinação, com opção de incrementar o controle da raiva através de ações de redução da população de cães errantes.

\subsection{Casos de Raiva}

A maior parte dos casos de raiva notificados na década de 90 em Recife, ocorreu em cães com domicílio de referência, dos quais, mais da metade não eram vacinados contra raiva, segundo informações dos proprietários. Como em Recife não existe um trabalho sistemático de recolhimento de animais mortos na rua para 
realização de exames, não é possivel ter uma melhor idéia da ocorrência de raiva em animais errantes.

Não há dúvidas que um aspecto central da persistência da raiva nos centros urbanos, principalmente de países subdesenvolvidos, é a existência de um elevado contingente de animais suscetiveis, sobretudo animais jovens. A ocorrência de casos de raiva em animais jovens e / ou não vacinados é comum (Belcher et al., 1976; Malaga et al., 1976; Kennedy, 1988; Bhatia, 1988; Beran e Frith, 1988; Burnes et al., 1991; Eng et al., 1994). Com freqüência, a maioria dos cães raivosos tinha dono (Belcher et al., 1976; Waltner-Toews et al., 1990; Eng et al., 1994). Outro aspecto a considerar são os diversos relatos de falhas vacinais ou de vacinação (Belcher et al., 1976; Bathia, 1988; Eng e Fishbein, 1990).

Analisando a Tabela 22 a seguir, observa-se que $41,17 \%$ dos casos de raiva canina de Recife ocorreram em animais com menos de dois anos, os quais representam $44,3 \%$ da população canina. A frequeência de casos segundo grupo etário é compatível com a frequêencia do grupo etário na população canina $(\mathrm{P}>0,05)$.

A elevada proporção de casos de raiva em cães não vacinados, freqüentemente cães jovens, coincide com a maior parte dos relatos da literatura, exceto que em Recife, os animais com até um ano não são responsáveis pela maioria dos casos de raiva. E mais, em Recife, a freqüência de casos de raiva em grupos etários mais velhos ainda é alta, e uma considerável fração dos casos ocorreu em animais com história de vacinação. 
Tabela 22: casos de raiva diagnosticados laboratorialmente (com idade registrada), entre 1993 e 1997, segundo o grupo etário, e freqüência de grupos etários de cães em Recife.

\begin{tabular}{lccc}
\hline & \multicolumn{2}{c}{ Casos de raiva canina } & Freqüência do grupo etário \\
\hline Idade & Total & $\%$ & $\%$ \\
1 a 4 meses & 12 & 17,65 & 18,2 \\
5 a 11 meses & 8 & 11,76 & 12,8 \\
1 ano & 8 & 11,76 & 13,3 \\
2 anos & 10 & 14,71 & 10,1 \\
3 anos & 13 & 19,12 & 10,3 \\
4 a 7 anos & 10 & 14,71 & 21,8 \\
8 a 10 anos & 7 & 10,29 & 13,5 \\
\hline Total & 68 & 100 & 100 \\
\hline
\end{tabular}

Ao contrário do que é relatado por Málaga et al. (1979) no Peru, onde a freqüência de casos de raiva diminui progressivamente e de forma consistente com o aumento da idade, em Recife, a freqüência de casos de raiva nos grupos etários mais jovens é proporcional à freqüência de animais nas respectivas idades, e animais com 2 a 3 anos de idade, que representam $20,4 \%$ da população, são responsáveis por $33,83 \%$ dos casos de raiva.

Somente a partir de 4 anos de idade começa a ocorrer uma diminuição relativa na frequêencia de casos, quando $35,3 \%$ da população são responsáveis por 25 $\%$ dos casos de raiva. Estes achados são compatíveis com os resultados da sorologia, que mostram o crescimento da proporção de imunes à medida que a idade aumenta, atingindo estabilidade e valores mais elevados em faixas etárias próximas a 4 anos. No México, Eng et al. (1994) citam que em condições de campo, apenas cães que receberam quatro ou mais doses de vacina inativada, produzida em cérebro de camundongos lactentes, estão consistentemente protegidos contra a raiva. Em São 
Paulo, avaliando cães vacinados em campanha, Almeida et al. (1997) demonstraram claramente a associação entre a resposta imune humoral em cães e o número de vacinações anteriores com a VCCL.

Durante o período entre 1993 e 1997 avaliado, é possível estabelecer dois grupos de animais raivosos: o primeiro, constituído de animais com menos de 2 anos de idade ( $41 \%$ dos animais com idade registrada), dos quais aproximadamente $81 \%$ não eram vacinados contra raiva; o segundo grupo é constituído por animais com idade a partir de 2 anos (59\% dos animais com idade registrada), e dentre estes, aproximadamente $56 \%$ tinham história de vacinação anterior contra raiva.

Mesmo considerando a limitação das informações quanto à história de vacinação prévia dos animais, os dados da pesquisa apontam para a existência de possíveis falhas no programa de vacinação, uma vez que muitos animais raivosos, de diferentes idades, principalmente animais com idade de até um ano, não eram vacinados contra raiva, e também para a existência de insucesso vacinal, devido à existência de casos de raiva em animais com história de vacinação, inclusive com múltiplas doses.

Adicionalmente, a avaliação das fichas dos casos de raiva também tornou evidente a existência de deficiências na condução dos inquéritos epidemiológicos.

\subsection{Imunidade}

\subsubsection{Aspectos relacionados à técnica sorológica}

No presente trabalho, adotou-se o critério de classificação como "boa resposta" / Vacinado imune (este último na modelagem matemática) o título de 0,5 UI / ml, conforme já foi justificado no item "Testes sorológicos". Em comunicados recentes sobre vacinação em cães, é comum o relato de resultados na forma de percentual de animais cujos títulos foram iguais ou superiores a $0,5 \mathrm{UI} / \mathrm{ml}$ (Vos et al., 1998; Aubert et al., 1998; Rupprecht et al., 1998 - citando apenas algumas 
referências), onde este valor é utilizado como referencial para avaliação da eficácia da vacinação em cães.

Smith et al. (1996) consideram que a prova rápida de inibição de focos fluorescentes (RFFIT) é ligeiramente mais sensivel que a prova de neutralização em camundongos, para a deteç̧ão de anticorpos neutralizantes em soros pós-vacinais.

Dentre 512 soros humanos testados por Smith et al. (1973), houve correlação completa entre 487 amostras. Nenhuma amostra positiva na neutralização em camundongos deixou de ser positiva na RFFIT, mas 25 amostras foram positivas na RFFIT e negativas na prova em camundongos. A maioria destas 25 amostras foram positivas quando testadas na diluição de 1:2 na prova em camundongos.

Para Smith et al.(1973), a RFFIT é um sistema comparável à prova de neutralização em camundongos para detectar baixos títulos de anticorpos. Nenhuma amostra dentre 100 soros humanos pré-imunização foi positiva na RFFIT. Esta prova deu resultados negativos em 20 soros normais (negativos) de raposas, guaxinins, jaritatacas (skunk), gambás (opossum), gatos, mangustos (mongoose) e cães, indicando que a mesma sensibilidade e especificidade pode ser esperada com soros de animais. Soros de animais vacinados tendem a apresentar títulos bastante comparáveis entre a RFFIT e a neutralização em camundongos, e a maioria dos soros foi positiva ou negativa em ambos testes.

Dean et al. (1964) citado por Smith et al.(1973, p.540) demonstraram que apenas $3 / 64$ cães vacinados $(4,7 \%)$, com titulos de anticorpos detectáveis no soro, sucumbiram ao desafio com vírus rábico, enquanto 19/21 (90,5\%) de cães utilizados como controle e 63/98 (64,3\%) de cães vacinados, mas sem títulos de anticorpos detectáveis, morreram.

No trabalho de Smith et al. (1973), aproximadamente $10 \%$ dos soros normais de animais (negativos) apresentaram evidência de inibição inespecífica do vírus em diluições menores que 1:5. Os autores sugerem que todos os soros de animais não vacinados ou com títulos esperados abaixo de 1:5 devem ser previamente tratados com kaolin.

No presente trabalho, os soros não foram tratados previamente com kaolin, sendo possivel a ocorrência de falsos títulos positivos. Entretanto, isso parece pouco provável, já que a diluição inicial de trabalho foi 1:5. 
Amostras de soro com hemólise também podem trazer problemas para a técnica em cultivo celular. Dentre todas as amostras testadas no presente trabalho, isto ocorreu com baixíssima freqüência, já que dispensou-se grande atenção aos fatores colheita de sangue, tempo, transporte, manuseio e centrifugação.

\subsubsection{Eficiência da imunização anti-rábica}

Os baixos níveis de anticorpos na população canina de Recife são preocupantes, quando comparados com resultados de avaliações em outros paises. Merecem destaque os achados de Chomel et al. (1988), no Peru, com $97 \%$ de cães possuindo títulos $\geq 0,5 \mathrm{UI} / \mathrm{ml} 12$ meses após a vacinação com vacina de cultivo celular, resultando em proteção semelhante tanto em animais primovacinados quanto em animais com história de vacinação.

Mas há relatos semelhantes aos de Recife, como é o caso de Araçatuba, em São Paulo (Silva et al., 1996), onde se encontrou $47 \%$ de animais com baixos títulos - utilizando a prova de soroneutralização em camundongos - 9 meses após a campanha de vacinação, metade dos quais vacinados contra raiva; São Paulo e Paulínia (Almeida et al., 1997), que encontraram aproximadamente $75 \%$ de animais com baixos títulos um ano após a campanha de vacinação (utilizando a RFFIT); e do Brasil (Germano et al., 1982) - utilizando a soroneutralização e imunofluorescência indireta; México (Eng et al., 1994) - com a RFFIT, sendo negativa a amostra com título < 5 (Reed-Muench) - e Indonésia (Hirayama et al., 1990) - utilizando soroneutralização em cultivo celular, e considerando positivos títulos 1:4 ou maiores (Reed-Muench). Relatou-se um rápido decréscimo no título de anticorpos contra raiva, particularmente em animais primovacinados. Em comum, nas localidades avaliadas se utilizava vacina inativada produzida em cérebro de camundongos lactentes, o tipo de vacina utilizado nas campanhas oficiais de vacinação anti-rábica no Brasil.

O valor imunogênico da VCCL é indiscutivel (Sikes et al., 1971; Fields et al., 1976), principalmente em condiçбes experimentais. Num outro trabalho contemporâneo a este, conduzido sob a supervisão do mesmo orientador deste 
trabalho (dados não publicados), a VCCL produziu curva de anticorpos substancialmente diferente da que foi encontrada em cães de Recife. Os cães de um grande canil, bem mantido, que recebe assistência veterinária e está submetido a um regime de vacinação regular e supervisionado, apresentaram elevados títulos de anticorpos, a partir de idades menores, com maior proporção de imunes nas diferentes faixas etárias.

Há também relatos de controle efetivo da raiva, através do uso da VCCL, como ocorreu na Argentina (Larghi et al., 1986). E também no Brasil, como ocorreu nos municípios de São Paulo e Curitiba, além de muitos outros existentes. Mas é preciso ter em mente que, além das medidas de controle da raiva existentes, em tipos e intensidades variáveis, é provável que em cada uma dessas localidades existissem condições ecológicas da população canina peculiares, possivelmente propícias à eliminação da raiva canina.

Neste trabalho repetidamente apontou-se a possível influência da qualidade de vida das populações humanas sobre a ecologia da população canina. Provavelmente, Buenos Aires, na Argentina, Curitiba, São Paulo, assim como outros municípios das regiões Sul e Sudeste do Brasil, que tiveram maior êxito no controle da raiva, possuiam condições gerais mais favoráveis à eliminação da raiva canina, em comparação com a cidade de Recife, que tem traços característicos do subdesenvolvimento que afeta toda a região Nordeste do Brasil.

Reforçando este ponto de vista, enquanto ocorreram importantes mudanças positivas na evolução do Índice de Desenvolvimento Humano (IDH) nas regiões Sul e Sudeste do Brasil entre as décadas de 80 e 90, a situação de diversos estados da região Nordeste, em particular Pernambuco, sofreu poucas mudanças, permanecendo estacionária em baixos índices (Figura 29). 
Figura 29: Evolução do índice de desenvolvimento humano segundo estados do Brasil, 1970-1996.

Indice de Desenvolvimento Humano (IDH), 1970-1996
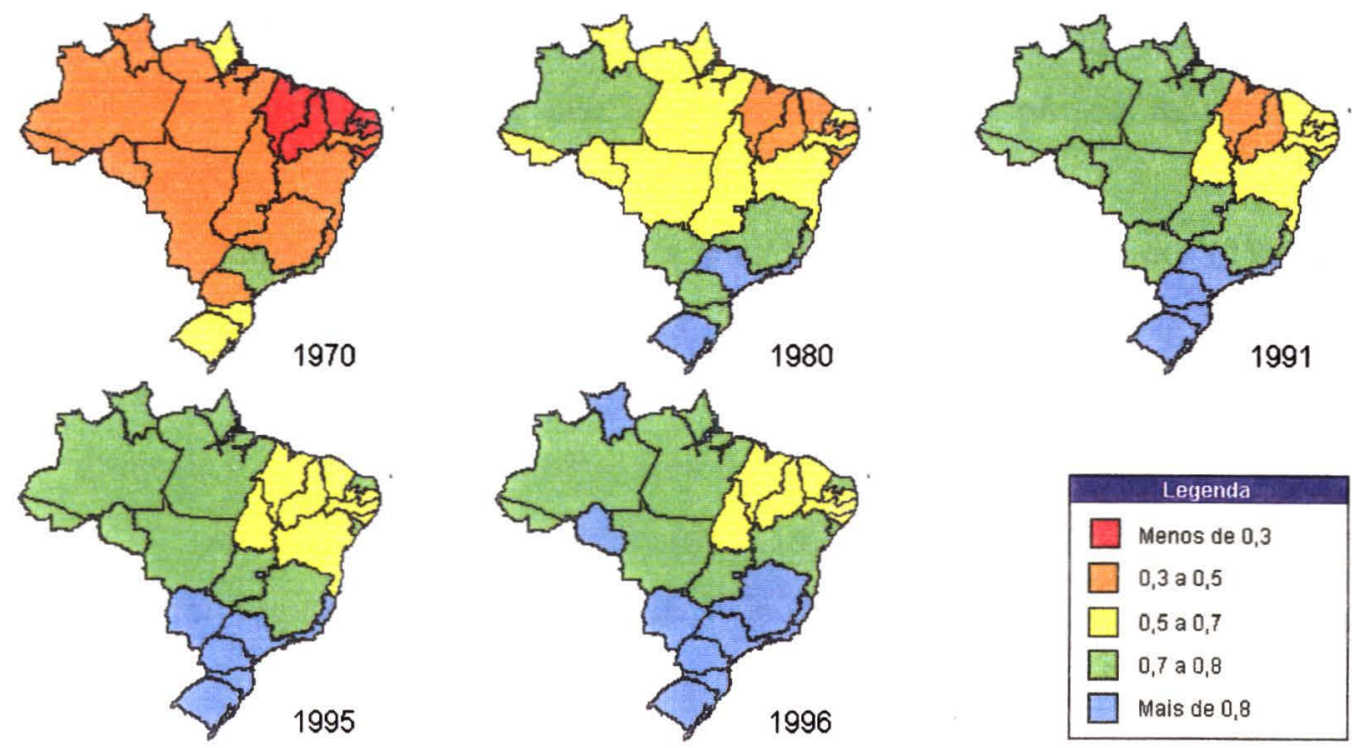

fonte: Martins (1998)

As diferenças são marcantes entre os IDH $^{19}$ das localidades citadas anteriormente. Buenos Aires: 0,887 (PNUD, 1996); Paraná: 0,847; São Paulo: 0,868; PE: 0,615 . Enquanto o IDH da região Nordeste vale 0,608 , este é igual a 0,857 na região Sudeste e 0,860 na região Sul (Martins, 1998).

Um questionamento feito por Almeida et al. (1997) parece se enquadrar neste ponto de vista aqui defendido: "Uma vez que o Município de São Paulo não apresenta casos de raiva há 13 anos, e considerando que os resultados indicam

19 'Três indicadores são usados para o cálculo do IDH. O primeiro refere-se à saúde e é captado por meio da esperança de vida ao nascer. $O$ segundo trata da educação, sendo mensurado com base na taxa de alfabetização de adultos, juntamente com a taxa de matrícula combinada nos três níveis de ensino. $\mathrm{O}$ terceiro visa a aferir a renda das pessoas em seu próprio país, e é medido pelo PIB per capita ajustado para diferenças no custo de vida de cada país, sendo o resultado expresso em PPP\$ (dólar da paridade do poder de compra)." (PNUD, 1997). 
que a maior parte dos cães não apresentam os níveis recomendados de anticorpos 12 meses após a última vacinação, deve-se procurar analisar qual a explicação para a não ocorrência de casos de raiva no município". Estes autores não propõem teorias para o fato, mas fazem considerações sobre o limiar do título de anticorpos que separa o indivíduo classificado como "protegido" daqueles "suscetíveis". É possível entretanto, que as condições ecológicas do município de São Paulo, dentre outras, não sejam mais propícias para a manutenção do ciclo epidemiológico da raiva canina.

Também corroborando com a visão defendida, Schneider (1990) classificou Recife, Fortaleza e Salvador, todas elas grandes capitais da região nordeste, como áreas de alto risco de raiva. São Paulo e Porto Alegre foram caracterizadas como áreas de médio risco, e Curitiba, área de baixo risco.

A classificação de Schneider (1990) se baseia nos aspectos (1) Situação epidemiológica (ocorrência de casos de raiva; vulnerabilidade; receptividade); (2) Ações de controle (relação entre unidades de saúde com tratamento e população; aplicação de soro; percentual de pessoas tratadas em relação a atendidas; percentual de abandono de tratamento; percentual de animais agressores observados; cobertura vacinal; controle de foco; percentual de amostras enviadas em relação à população canina estimada; posto de atendimento animal; controle do morcego hematófago; existência de laboratório de diagnóstico); (3) Condições estruturais (mortalidade proporcional; migração; abastecimento por rede pública de água; renda de até dois salários mínimos; analfabetismo). Esta classificação inclui ainda divisão dos sub itens.

É provável que nas condições prevalentes em alguns grandes centros urbanos, fatores como condições heterogêneas de vacinação, erros de manipulação das vacinas, estrutura etária e mortalidade da população canina, dentre outros, reduzam a eficiência da imunização com a VCCL. Alguns dos citados elementos também podem ocorrer em outras condições, mas o que torna estes eventos relevantes, são justamente as condições ecológicas peculiares desses grandes centros urbanos em regiões pobres, que fazem revelar os efeitos da ineficiência.

Em países da América do Sul e América Latina, há evidências de que uma maior proporção de cães imunes é encontrada em faixas etárias mais velhas, em 
função da maior probabilidade destes animais terem recebido múltiplas doses da VCCL (Málaga et al., 1976; Eng et al., 1994).

Nas condições de Recife, com:

- níveis de cobertura de vacinação apenas razoáveis;

- sendo as campanhas públicas anuais a principal forma de vacinação da grande maioria da população canina;

- com animais vacinados pela primeira vez em idade tardia (média de 10 meses), resultado principalmente do elevado número de nascimentos;

- elevada proporção de animais primovacinados com a VCCL, os quais apresentam rápida perda de imunidade;

- e elevada renovação populacional, com mortalidade de uma fração dos animais imunes e novo aporte de suscetíveis através de nascimentos,

justifica-se a existência de baixos níveis de imunidade populacional.

Na Tunísia, Haddad et al. (1988) mencionam que a duração da imunidade é reduzida pela elevada taxa de renovação da população canina, com 21 a $33 \%$ da população desaparecendo em um ano, e 43 a $52 \%$ em dois anos, à semelhança de Recife.

Parece pouco provável que fatores nutricionais e doenças tenham importância destacada na imunidade populacional. Os cães capturados de Recife estavam ainda mais desprotegidos do que os cães da amostra de domicílios, mas é provável que a maioria destes cães não fosse vacinada contra raiva. Possivelmente, animais capturados apresentam maior probabilidade de estarem sujeitos a menores níveis de restrição e de cuidados por parte dos seus proprietários, além de provavelmente também serem mais jovens, o que aumenta a chance de não serem imunizados, ou terem recebido menor número de doses de vacina anti-rábica.

No Brasil, Soares et al. (1992), se baseiam nos resultados de um estudo experimental para recomendar, veementemente, a eliminação de cães de rua. Estes autores entretanto, extrapolam as conclusões obtidas experimentalmente com animais 
confinados e em más condições de saúde e nutrição, para a população de "cães de rua", o que deve ser avaliado com reservas:

- o termo cão de rua é um termo mal definido;

- supondo que signifique cão errante ou mesmo animais não restritos ou semi-restritos, sabe-se que muitos desses animais possuem donos ou pessoas que os protegem e os alimentam;

- ainda que não haja quem os alimente, o ambiente urbano é rico em alternativas para alimentação de cães errantes;

- animais errantes não são necessariamente desnutridos e doentes, nem tão pouco se conhece que proporção dos animais de rua apresentam tais características, em diferentes localidades.

- Além do mais, existem relatos na literatura, citados neste trabalho, que comprovam a capacidade de cães criados em áreas de baixo status socioeconômico, em condição de saúde e nutrição aparentemente diferente da que se observa entre cães criados em áreas de elevado status socioeconômico, responderem bem à vacinação anti-rábica.

Chomel et al. (1988) no Peru, e Eng et al. (1994) no México, e Almeida et al. (1997) no Brasil, não encontraram evidências de que fatores nutricionais justifiquem uma pobre resposta à vacinação anti-rábica na população. Pelo contrário, nestes dois primeiros trabalhos citados, os autores demonstraram que os cães de áreas de baixo poder aquisitivo, respondem adequadamente a bons imunógenos.

Diante dos diversos aspectos discutidos neste tópico, ganha evidência a importância de se considerar fatores ecológicos da população canina, relacionados a fatores socioeconômicos, nos processos de avaliação de insucessos dos programas de vacinação anti-rábica em algumas localidades do Brasil. Até então, parece ser prevalecente a ênfase no questionamento da (falta de) condução correta dos programas tradicionais, os quais preconizam os métodos clássicos de controle da raiva canina. 


\subsection{Estacionalidade}

A série de casos de raiva canina aqui analisada não permite evidenciar que em Recife a raiva apresenta um comportamento cíclico estável, pois não se avaliou uma série de longo prazo. Entretanto, os efeitos da componente cíclica sobre os casos de raiva canina evidenciaram uma maior influência se repetindo a intervalos anuais.

E mesmo tendo se passado mais de 20 anos da implantação do Programa Nacional de Profilaxia da Raiva no Brasil, a raiva persiste em Recife, com freqüência nitidamente influenciada pela época do ano. Maiores índices estacionais coincidem com maior freqüência de partos em cadelas, embora não se possa estabelecer uma relação de causa e efeito entre estes fatores.

Diversos trabalhos, citados a seguir, relatam aspectos do comportamento estacional da raiva canina em vários países, e possíveis explicações para o mesmo.

Narayan (1985), na Índia, observaram maior freqüência de casos de raiva em certos meses do ano, e sugerem que as oportunidades de contato podem ocorrer mais em certas épocas, influenciado principalmente por fatores fisiológicos. Este autor considera importante o período de desmame, devido à maior suscetibilidade dos animais jovens. Mas o período de estro, quando os animais percorrem longas distâncias e lutam entre si, provavelmente oferece maior probabilidade de transmissão da raiva.

Relatos aparentemente contraditórios foram realizados na Índia. Rajan et al. (1990), observaram maior incidência de casos positivos de raiva nos meses do verão e inverno, sendo que essas estações coincidem com a estação de acasalamento dos cães. Por outro lado, em Delhi, Bhatia et al. (1988) descrevem uma diminuição dos casos de raiva nos meses de verão, e atribuem esta tendência a uma menor atividade dos cães devido ao calor intenso do verão.

$\mathrm{Na}$ Tunísia, Chadli et al. (1982) citam um aumento no número de pessoas mordidas e tratadas contra raiva nos meses quentes, com diminuição deste número nos meses frios. 
Belcher et al. (1976), em Gana, citam picos de raiva canina nos meses de setembro e outubro, e avaliam que se o período de incubação for de 1 a 2 meses, a transmissão deve ter ocorrido nos meses de julho a setembro, meses mais frios, e nos quais os veterinários relatam aumento no comportamento de acasalamento, com machos lutando pelas fêmeas e cães perambulando em grandes quantidades. Para um controle mais efetivo da raiva canina, as campanhas de vacinação teriam de preceder esses períodos.

De maneira oposta, Alonge e Abu (1984) não observaram estacionalidade da raiva canina em Gana. Este autores citam que neste país, a maioria dos cães vagam livremente pelas ruas, tendo livre acesso a todos os domicílios durante todo o ano. Conforme mencionado pelos mesmos, em Gana, o clima é tal que nem a estação chuvosa nem a estação seca restringem o livre movimento dos homens e animais, como ocorre em climas temperados, não havendo, segundo eles, razão para um comportamento estacional da raiva.

Torres (1982), menciona que na fronteira norte do México, nas décadas de 60 e 70, observou-se uma maior incidência de raiva canina nos meses de primavera, com ciclos a cada 5 anos, atribuídos às baixas coberturas de vacinação (devido a um tamanho subestimado das populações caninas).

Em Tamaulipas, também no México, Burnes et al. (1991) citam um aumento de envio de amostras para diagnóstico de raiva nos meses de primavera, explicado pela temporada de acasalamento dos cães, com aglomerações, maior número de agressões e contatos.

No Peru, Málaga et al. (1976) relatam um comportamento estacional da raiva canina, com aumento na primavera (setembro a novembro) e redução no outono e princípio do inverno (maio a julho), explicado pela época do cio nas cadelas, com maior freqüência na primavera, e maior risco de exposição, devido à maior probabilidade de contato entre os animais.

Num outro trabalho realizado no Peru, Malaga et al. (1979) observaram picos de estro nas cadelas entre março e abril e entre setembro e outubro, enquanto os maiores picos de nascimento ocorrem entre abril e junho. Os picos de raiva iniciam em agosto e chegam ao máximo em outubro, sugerindo uma associação entre a mudança de estrutura etária da população canina ao longo do ano - a qual 
influencia a imunidade populacional - e a incidência de raiva canina. Esta explicação é reforçada pela observação de $28 \%$ dos casos de raiva em cães com até 6 meses de idade, e $15 \%$ dos casos em animais com 7 a 11 meses, enquanto que apenas $28 \%$ da população canina tem menos de 1 ano de idade.

Ernst e Fabrega (1989) mencionam que no Chile, durante uma fase de inexistência de programas de controle de raiva, existia uma tendência de aumento do número de casos de raiva canina; nos primeiros 10 anos da implantação de um programa de controle, percebeu-se uma tendência nítida de redução do número de casos; numa fase mais avançada do programa, após os primeiros 10 anos, verificouse um reduzido número de casos de raiva, mas sem tendência significante de redução. Havia comportamento estacional da raiva canina, com picos em outubro e novembro, e menores índices em fevereiro e abril, antes da implantação até os primeiros dez anos de programa. Após os 10 primeiros anos de programa, a estacionalidade desapareceu. Os ciclos a cada cinco anos, anteriormente existentes, deixaram de ser evidentes após os dez anos de programa. Os citados autores concluem que a estacionalidade desapareceu quando a doença passou a ocorrer com baixa freqüência, em conseqüência da captura e eliminação de cães errantes, e redução do número de animais suscetíveis através da vacinação dos cães com domicílio.

Embora haja uma certa tendência de se atribuir maior freqüência de casos de raiva aos meses de primavera e verão, existe maior concordância de que a estação de acasalamento dos cães, que pode ocorrer em meses diferentes nos diversos países, é um período de maior risco de transmissão da raiva.

Entretanto, a maioria dos trabalhos, ao citar maior freqüência de casos de raiva canina coincidindo com as estações de acasalamento, não discutem adequadamente o período de incubação da doença. Parece não haver dúvidas quando ao aumento do risco de transmissão da raiva nos períodos de acasalamento dos cães, mas Alonge e Abu (1984) podem ter razão, ao menos em parte, ao afirmar que, se os cães vagam livremente em qualquer época do ano, em um país com condições climáticas adequadas para tal, parece não haver motivos para que a raiva canina apresente comportamento estacional naquele país, ao menos que sejam justificados pelos contatos durante os acasalamentos. 
Inúmeros fatores podem estar relacionados ao comportamento estacional da raiva em um lugar em particular, dentre eles, os fatores climáticos, as estações de acasalamento, os níveis de restrição a que os cães são submetidos, e também, as ações de controle da raiva, incluindo a captura e eliminação de cães e a vacinação.

A julgar pela associação de evidências até aqui apresentadas, Malaga et al. (1979) são aqueles que melhor explicam o comportamento estacional da raiva, quando sugerem uma coincidência entre elevadas freqüências de suscetíveis na população (nascidos em meses anteriores) e maior incidência de raiva, numa população onde a freqüência de nascimentos varia ao longo do ano.

O cão jovem, estará sujeito a um maior risco de raiva, no momento em que ele começar a ter relações sociais com outros cães. Isto ocorrerá com maior freqüência logo após o desmame, que ocorre comumente aos dois ou três meses de idade, que é a idade em que as pessoas costumar dar os filhotes. Nesta idade, a imunidade passiva porventura existente, também começa a desaparecer. Se a transmissão da raiva ocorre a partir deste período, a doença irá se manifestar aproximadamente entre 20 e 90 dias depois. Se somarmos, a partir do período de acasalamento, dois meses de gestação, mais dois meses de desmame, e outros dois meses de incubação da doença, o desfecho irá ocorrer ao menos 6 meses depois do acasalamento que deu origem àquele animal.

Deste modo, os efeitos dos nascimentos ocorridos em uma estação, decorrentes de uma estação de acasalamentos ocorrida anteriormente, só irão se manifestar meses depois, numa outra estação de casos de raiva.

Considerando os dados obtidos em Recife, entre os anos de 1996 e 1997, observou-se que a frequência de amostras positivas para raiva, para cada mês do ano em particular, são semelhantes nestes dois anos. Os valores médios para a freqüência de amostras positivas está representado na Figura 30 a seguir. Aparentemente, existe uma tendência de aumento de positividade nos meses do final do ano, com picos em agosto e dezembro. 
Figura 30: percentual de amostras de origem canina positivas para raiva, segundo o mês, entre os anos de 1996 e 1997.

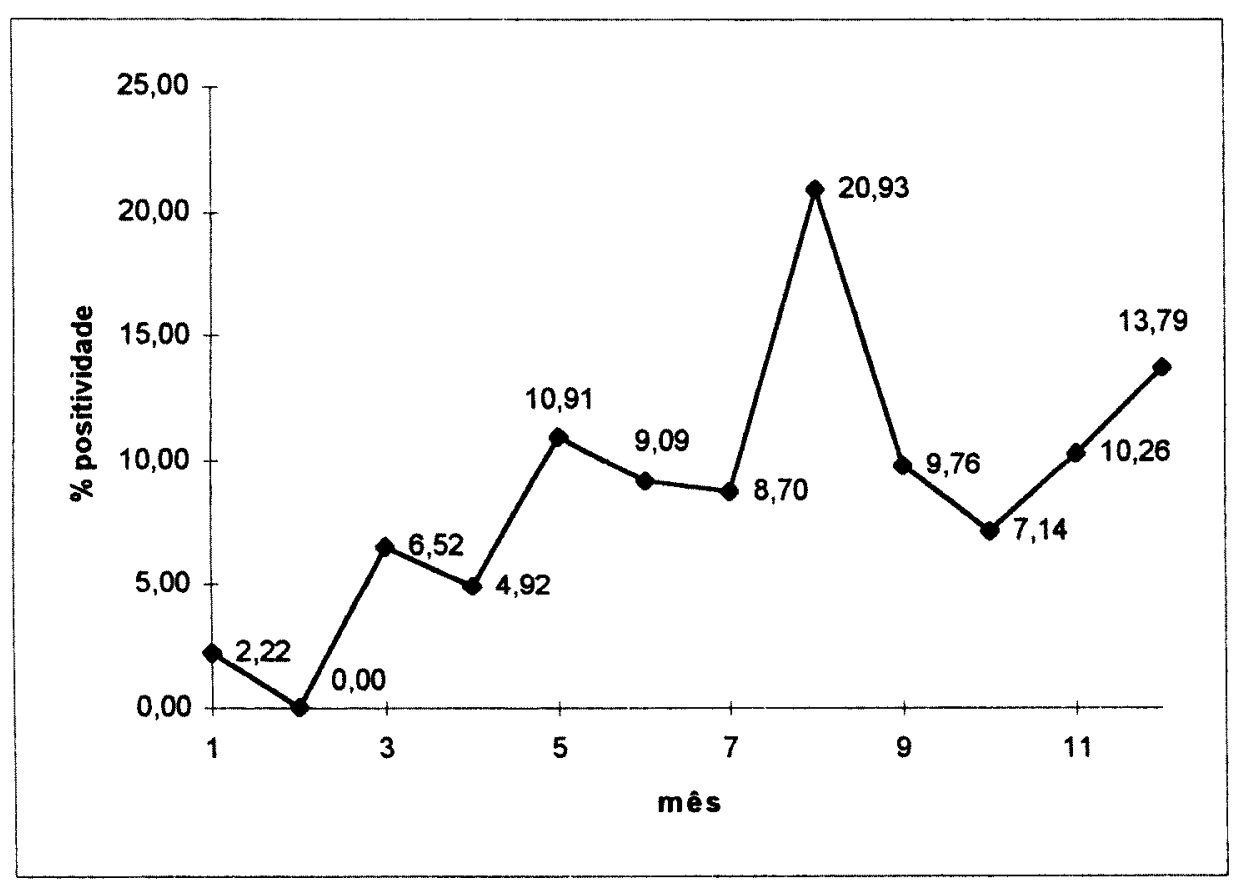

Fonte dos dados: LAPA / Recife.

Associando estes dados aos índices estacionais para raiva, e ao percentual de partos em cadelas, estimados no presente trabalho, obtém-se a Figura 31 a seguir. 
Figura 31: índices estacionais para raiva, percentual de partos em cadelas e percentual de amostras positivas em exame laboratorial para raiva, Recife, PE.

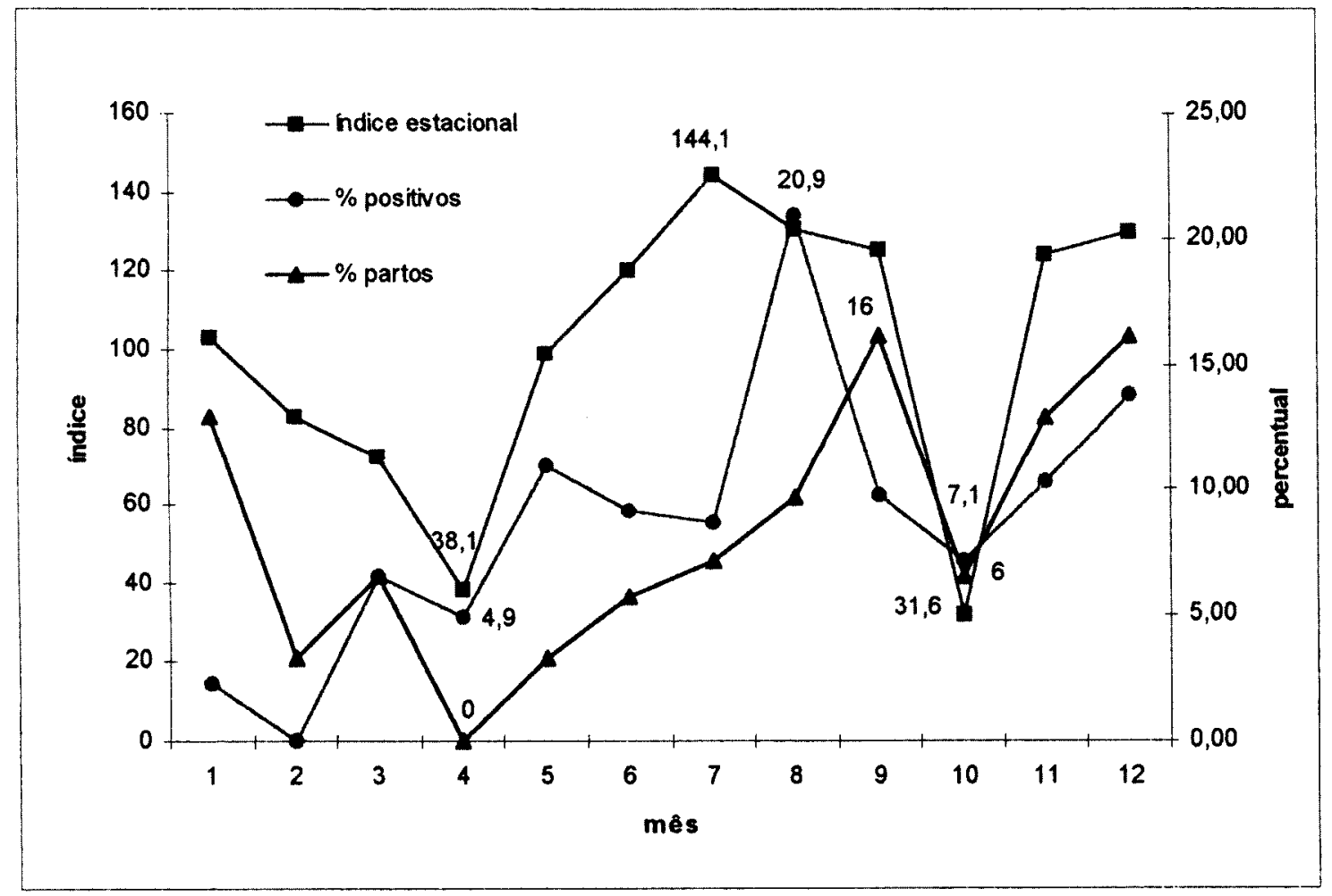

Três aspectos tornam-se evidentes:

(1) o menor índice estacional, uma baixa proporção de amostras positivas em laboratório, e o menor percentual de partos coincidem todos com o mês de abril;

(2) a partir do mês de abril, todos esses três valores se elevam progressivamente, atingindo valores máximos no segundo semestre do ano, antes do mês de outubro;

(3) todos os três valores, coincidentemente, caem abruptamente no mês de outubro, voltando a subir logo depois, até o mês de dezembro, quando iniciam novo decréscimo que vai até o mês de abril. 
Se o pico de partos ocorre em setembro, e se aceitamos que os casos de raiva em animais jovens ocorrerão num período que inicia a partir de seis meses da concepção daquele animal, a doença irá se manifestar, naquele indivíduo, a partir do mês de abril. Neste mês, os índices estacionais e percentual de amostras positivas são mínimos, mas a partir daí estes valores se elevam progressivamente, até o mês de setembro.

O mês de outubro ocorre no mês seguinte à campanha anual de vacinação anti-rábica em Recife. Devemos considerar que se o animal é vacinado em setembro, a imunidade irá atingir o seu limiar entre três e quatro semanas depois, o que ocorre no mês de outubro, explicando o decréscimo abrupto na freqüência de amostras positivas e nos índices estacionais, e indicando uma interrupção temporária no ciclo de transmissão da doença. O crescimento temporário dos casos até o mês de dezembro, seria explicado pela existência de casos tardios em animais já em periodo de incubação anterior à campanha de vacinação. Além disso, durante o período de campanha e nas semanas que antecedem e sucedem a esta, existe uma redução significativa nos esforços de captura de cães errantes. E provavelmente também diminui a vigilância e busca de casos, devido ao deslocamento de pessoal e recursos para as atividades de campanha de vacinação anti-rábica, assim como para a avaliação desta, da qual participam técnicos que atuam na coordenação e execução das atividades mencionadas.

Passado o mês de dezembro, a freqüência de raiva diminuiria em função da redução temporária da população suscetível e das taxas de transmissão. Entretanto, a perda progressiva de imunidade em uma fração da população, juntamente com o crescimento da população de suscetíveis em consequeência dos nascimentos, reiniciaria um novo ciclo.

Embora não possamos pensar nessas considerações hipotéticas como uma fórmula matemática, que inflexivelmente fornecerá resultados exatos, elas parecem ser uma explicação razoável para o comportamento da raiva em Recife.

Considerando o exposto, a análise do comportamento temporal dos casos de raiva canina na cidade de Recife, limitada em função da possível subnotificação dos casos, especialmente em certos períodos da série analisada, indica que, possivelmente, os nascimentos das ninhadas de cães, que parecem ter 
comportamento estacional, são um dos principais fatores condicionantes da doença. Tais nascimentos são responsáveis pelos aumentos periódicos e repetidos na população de animais suscetíveis.

Contribui ainda para o comportamento da raiva em Recife, através do aumento dos suscetíveis na população, a perda de imunidade em animais vacinados, a qual deve ser mais rápida em animais primovacinados. As campanhas de vacinação anti-rábica, repetidas anualmente em um mesmo mês, e sendo a principal opção de vacinação anti-rábica da população canina de Recife, cobrem uma fração limitada desta população, por não atingirem os animais ainda jovens no período da campanha, ou nascidos nos meses subseqüentes à mesma. Este quadro tende a originar um comportamento padronizado de perda de imunidade e surgimento de novos suscetíveis, com crescimento gradual deste contingente ao longo do ano, resultando em padrões cíclicos e estacionais dos casos de raiva canina, ao interagir com os padrões de natalidade e mortalidade desta mesma população.

Assim, entre uma campanha de vacinação e outra, aumenta progressivamente a população de animais suscetiveis, atingindo esta seus valores mais elevados no período que antecede as campanhas de vacinação. Após a campanha, o número de suscetíveis diminui, mas não em quantidade e por tempo suficientes para eliminar o vírus da população. Para tal, contribuem as insuficientes coberturas de vacinação, baixa eficiência da imunização, e insuficiente tempo de duração da imunidade (sobretudo em animais primovacinados, que correspondem a aproximadamente 1/4 da população vacinada), além do relativamente longo período de incubação da doença. Isto deve garantir os limiares suficientes para manutenção do vírus, e em pouco tempo, os nascimentos de suscetíveis, a perda de imunidade, e a mortalidade de animais imunes voltam a aumentar esta população suscetível.

Este fenômeno parece explicar não só a estacionalidade da doença, mas também a manutenção do vírus na população animal. Isto, em associação à biologia da população canina, apresentando elevadas taxas de natalidade e mortalidade, e baixa expectativa de vida, provavelmente está associado ao comportamento cíclico da raiva canina no centro urbano de Recife.

Relativamente ao controle da doença, as campanhas de vacinação têm apresentado resultados de impacto limitado e de curta duração, sendo incapazes, nas 
condições em que são realizadas atualmente, de eliminar o vírus da população canina.

\subsection{A dinâmica da doença}

As simulações que foram realizadas têm como objetivo maior indicar tendências de resposta a possiveis métodos de intervenção. Estas, embora utilizem métodos quantitativos, oferecem respostas mais qualitativas do que previsões quantitativas dos resultados das intervenções.

Em relação à realidade atual da cidade de Recife, as melhores respostas em termos de controle da raiva tendem a ser obtidas através do aumento das taxas de imunização efetiva, e redução da idade à primeira vacinação.

Anderson e May (1992) discutem o efeito da idade à primeira imunização em programas de erradicação de uma infecção. A erradicação se torna mais fácil se os indivíduos forem vacinados na idade mais precoce possivel, sem deixar de levar em conta as complicações dos anticorpos maternais.

Em média, a imunização deve ocorrer antes que $o$ indivíduo adquira a infecção, o que é razoável. A erradicação é simplesmente impossível se a idade média à primeira vacinação for maior que a idade média de aquisição da infecção (Anderson e May, 1992). Deve ser observada a elevada idade média à primeira vacinação contra raiva dos cães de Recife (10 meses), e a elevada freqüência de casos de raiva em cães jovens.

A redução da taxa de perda de imunidade certamente seria positiva, mas não tanto quanto os dois fatores citados anteriormente, em parte devido às elevadas taxas de mortalidade, que diminuem o efeito da imunidade duradoura. A diminuição nas taxas de mortalidade da população canina de Recife tendem a favorecer a eliminação da raiva. 
Aumentos nas taxas de imunização podem ser obtidos de diversas maneiras:

a) aumentando a cobertura de vacinação, o que não ajudará muito se esta vacinação não produzir resultados efetivos; e que também não parece ser muito fácil nas atuais condições existentes em Recife, a julgar pelos resultados constantes ao longo dos últimos anos;

b) utilização de vacinas mais imunogênicas que protejam igualmente os animais, independente da história prévia de vacinação, resultando em imunidade mais intensa e mais duradoura;

c) aumento na freqüência da vacinação anti-rábica, como por exemplo, a realização de vacinações estratégicas em áreas de risco, ou a redução do intervalo entre campanhas, sendo esta última menos factível;

d) ou realização de extensas coberturas em áreas de maior risco, em época diferente da campanha de vacinação anual, já que há restrições quanto à viabilidade de campanhas públicas muito freqüentes. Esta opção traria ainda um outro benefício, que seria a oferta de vacina a animais que não puderam ser vacinados em campanha anterior, geralmente por serem jovens, ou por terem nascido após a campanha anual, como se observou neste trabalho.

A redução da idade à primeira vacinação poderia ser obtida como resultado das campanhas ou ações localizadas, realizadas ao menos duas vezes ao ano, ou ainda através de ações seletivas continuadas ao longo do ano. E no sistema atual de campanhas, seria possível mediante campanha de esclarecimento específica para este fim.

Vacinas mais imunogênicas tenderiam a produzir imunidade duradoura, uma vez que títulos elevados irão demorar mais até que caiam a baixos níveis.

Quanto à mortalidade da população canina, não pode ser vista dissociada da natalidade, já que as taxas de sobrevivência parecem estar relacionadas à capacidade de suporte do meio, que por sua vez deve condicionar os nascimentos. Esta, parece não estar ao alcance direto dos programas de controle da raiva, exceto se existir opção por intensificação da captura e eliminação de cães, como parece estar 
acontecendo em Recife (Figura 28). Os possiveis efeitos de tais ações já foram mencionados no tópico resultados.

Diminuições substanciais nas taxas de mortalidade possivelmente só serão conseguidas no momento em que as populações humanas atingirem melhores niveis de condições de vida, possibilitando a partir dai, estender estas melhorias aos seus animais de estimação.

Certamente, aí reside um dos motivos pelos quais alguns municípios do Brasil conseguiram obter o controle da raiva, empregando as medidas preconizadas pelo Programa Nacional de Profilaxia da Raiva, quando alguns outros, geralmente localizados em regiðes menos favorecidas economicamente, tiveram insucesso, pois ainda não atingiram o limiar necessário à eliminação do vírus rábico na população canina - a partir do qual os resultados dos programas passariam a ser efetivos. 


\section{Conclusões}

- A estimativa oficial do tamanho da população canina de Recife (1 cão para 10 habitantes) não difere significativamente da estimativa do estudo. Como as estimativas na amostra indicam tamanho ligeiramente superior ao estimado oficialmente, particularmente em algumas regiōes da cidade, devem ser consideradas as implicações de uma possível subestimação em relação ao planejamento e avaliação das atividades de controle da raiva.

- A densidade populacional de cães, particularmente a densidade de suscetíveis, é suficiente para manter o vírus rábico na população canina. Como existe elevada proporção de animais sem restrição completa, há uma maior probabilidade de contatos entre animais infectados e suscetíveis, favorecendo a transmissão do vírus rábico.

- As altas taxas de fecundidade, e os baixos níveis de cuidados e de restrição em geral, interagem e implicam em elevadas taxas de natalidade e de mortalidade, originando uma estrutura etária com predominância de cães jovens. Como o fator idade está diretamente relacionado aos títulos de anticorpos contra raiva, estes elementos são responsáveis, em grande parte, pela ineficiência das estratégias de vacinação.

- Em Recife, as deficiências operacionais em campanha devem ser melhor avaliadas, já que é possível que reduzam a eficiência do processo de imunização anti-rábica.

- Os casos de raiva em Recife são em parte, conseqüência da elevada proporção de cães jovens e não imunes ou com baixos títulos de anticorpos, mas também estão relacionados a baixos níveis de proteção em animais adultos, sugerindo a existência de falhas no programa de vacinação ou também insucesso vacinal. Como a grande maioria dos casos foi registrada em animais com domicílio de referência, não se pode 
atribuir o problema exclusivamente à população de cães errantes, cuja maior parte não é acessível às campanhas de vacinação.

- Além de fatores ecológicos, as variações na proporção de animais suscetíveis, ao longo do ano, condicionadas pela natalidade, mortalidade, eficiência e época da campanha de vacinação, provavelmente explicam a persistência da raiva na população canina de Recife, assim como o seu comportamento estacional.

- Dentre as possíveis alternativas para aumentar a eficiência do controle da raiva em Recife, o aumento nas taxas de vacinação, sobretudo associada a um sólido estado de proteção com uma única dose de vacina, e também a redução na idade média à primeira vacinação, para valores tendendo a quatro meses ou menos, são as alternativas com maior potencial de êxito.

- Um aumento na expectativa de vida da população canina tenderá a ser benéfico, por implicar em melhor estado de proteção contra raiva, além de redução na fecundidade. Este aumento deverá ser acompanhado de ações que estimulem a restrição da atividade reprodutiva dos cães, e também restrição da movimentação dos mesmos, cabendo observância das leis.

- Uma vez que os recursos devem ser gerenciados com racionalidade para o efetivo controle da raiva em grandes centros urbanos, os indicadores de tipo de domicílio, renda per capita familiar e instrução de chefes de família, podem ser utilizados para identificar áreas de maior risco de raiva, facilitando a decisão de alocação de recursos.

Espera-se, com esses achados, que novos elementos sejam incluídos nas discussões para elaboração de diretrizes do controle da raiva na região Nordeste e em outras regiões mais desfavorecidas do Brasil. 


\section{REFERENCIAS}

ACHA,P.N.; SZYFRES, B. Zoonosis y enfermedades transmisibles comunes al hombre y a los animales. Segunda edición, Organizacion Panamericana de la Salud, Washington, 1986. [Publicación Científica no. 503]

AKAKPO, A.J. BORNAREL, P.; SARRANDIN, P.; LEYE, S.M. ALAMBEDJI, R. Socio-ethnologie et rôle du chien dans le département de Pikine (Zone suburbaine de Dakar - Sénégal). Dakar Médical, 35(1): 99-105, 1990.

ALMEIDA, M.F.; AGUIAR, E.A.C.; MARTORELLI, L.A.F.; PRESOTTO, D.; BRANDÃO, M.M.; PEREIRA, O.A.C. Resposta imune humoral de cães à vacina inativada, de cérebro de camundongos lactentes, utilizada nas campanhas antirábicas no Brasil. Revista de Saúde Pública, 31(5): 502-507, 1997.

ALONGE, D.O.; ABU, S.A. Rabies in Ghana, West Africa. Int. J. Zoon., 11: 53-58, 1984.

ANDERSON, R.M. The population dynamics of infectious diseases: theory and applications. London, Chapman and Hall, 1982.

ANDERSON , R.M. \& MAY, R.M. Infectious diseases of humans - dynamics and control. Oxford Science Publications, 1992.

ANDERSON, R.M.; JACKSON, H.C.; MAY, R..M. \& SMITH, A.M. Population dynamics of fox rabies in Europe. Nature, 289 (5800): 765-771, 1981.

AUBERT, M. Control of rabies in foxes: what are the appropriate measures? The Veterinary Record, 134 (3): 55-59, 1994.

AUBERT, M.; SEGHAIER, C.; ClIQUET, F.; AOUINA, T.; TLATLI, A.; HAMMAMI, S. Mass vaccination campaign against rabies in Tunisia: are vaccinated dogs correctly immunized ? In: IX Reunion internacional sobre avances en la investigacion y control de la rabia en las Americas. 1998 diciembre 8-12. Puerto Vallarta, Mexico. 1998, p. 44.

BHATIA, R.; BHARDWAJ, M.; SEHGAL, S. Canine rabies in and around Delhi - a 16 years study. J. Com. Dis., 20(2): 104-110, 1988.

BECK, A. The ecology of stray dogs - a study of free-ranging urban animals. Baltimore, York Press, 1973. 98p. 
BECK, A.M. The public health implications of urban dogs. A.J.P.H., 65(12): 1315 $1318,1975$.

BELCHER, D.W.; WURAPA, F.K.; ATUORA, D.O.C. Endemic rabies in Ghana.

The American Journal of Tropical Medicine and Hygiene, 25(5): 724-729, 1976.

BELOTTO, A.J.; LUARCA, E.G.; GOMES, F.J.P.; JÚNIOR, J.B.R. Vacinação anti-rábica canina no Brasil. Revista da Fundação SESP, 22(2):___, 1977.

BELOTO, A.J. A raiva no Brasil eme 1984. Aspectos operacionais e epidemiológicos. Revista da Fundação SESP, RJ, 30(2): 167-182, 1985.

BELOTTO, A.J. Organization of mass vaccination for dog rabies in Brazil. Reviews of infectious diseases, 10(suppl.4): 693-696, 1988.

BERAM. G.W.; FRITH, M. Domestic animal rabies control: an overview. Reviews of infectious diseases, 10 (suppl.4): 672-677, 1988.

BERAN, G.W.; NOCETE, A.P.; ELVIÑA, O.; et al. Epidemiological and control studies on rabies in the Philippines. Southeast Asian J. Trop. Med. Pub. Health, 3(3): 433-445, 1972.

BERQUÓ, E.S.; SOUZA, J.M.P.; GOTLIEB, S.L.D. Bioestatística, la ed. revista, São Paulo, E.P.U.(Editora Pedagógica e Universitária Ltda.), 1981. 350p.

BINGHAM, J.; SCHUMACHER, C.L.; AUBERT, M.F.A.; HILL, F.W.G.; AUBERT, A. Innocuity studies of SAG-2 oral rabies vaccine in various Zimbabwean wild non-target species. Vaccine, 15(9): 937-943, 1997.

BOGEL, K.; MESLIN, F.-X. Economics of human and canine rabies elimination: guidelines for programme orientation. Bull. W.H.O., 68 (3): 281-291, 1990.

BOTA, C.N.; ANDERSON, R.K.; GOYAL, S.M.; CHARAMELLA, L.J.; HOWARD, D.R.; BRIGGS, D.J. Comparative prevalence of rabies antibodies among household and unclaimed / stray dogas as determined by the immune adherence haemagglutination assay. International Journal of Epidemiology, $\underline{16}(3): 472-476,1987$.

BOURHY, H.; LAFON, M.; BERTHONNEAU, M.C.; RENNER, Y.; ROLLIN, P.E.; SUREAU, P. Veterinary Record, 122: 361-362, 1988.

BROOKS, R. Survey of the dog population of Zimbabwe and its level of rabies vaccination. Veterinary Record, 127(24): 592-596, 1990. 
BURNES, J.M.; PAZ, A.M.; SOLARES, A.C. et al. Técnicas comparativas para el diagnóstico de rabia y su incidencia en Tamaulipas en 1987. Rev. Lat-amer. Microbiol., 33: 209-217, 1991.

CAMPOS-FILHO, N.; FANCO, E. L. A microcomputer program for multiple logistic regression by unconditional and conditional maximum likelihood methods. Amer. J. Epidemiol., 129 (2): 439-444, 1989.

CARTER, C.N. Pet population control: Another decade without solutions? Journal of the American Veterinary Medical Association, 197(2): 192-195, 1990.

CASTIGNOLLES, N.; MORGEAUX, S.; GONTIER-JALLET, C.; et al. A new family of carries (biovectors) enhances the immunogenicity of rabies antigens. Vaccine, 14(14): 1353-1360, 1996.

CENTER FOR DISEASE CONTROL \& PREVENTION, WORLD HEALTH ORGANIZATION. Epi Info. A word processing, database and statistics program for public health [programa de computador]. Atlanta: OPAS/WHO; 1997.

CENTRO PANAMERICANO DE FEBRE AFTOSA. Caracterizacion de la poblacion animal, 1979. ( Série de manuales didacticos, $\mathrm{n}^{\circ} 13$ )

CHADLI, A.; BAHMANYAR, M.; CHAABOUNI, A. Epidémiologie de la rage en Tunisie. Etude comparative des résultats de 28 dernières années. Archs Inst. Pasteur, Tunis, 29(1): 5-21, 1982.

CHAMELET, E.L.B. Infectividade da saliva e glândulas salivares submaxilar e parótida de cães raivosos naturalmente infectados. São Paulo; 1986. [Dissertação de Mestrado, Departamento de Epidemiologia, Faculdade de Saúde Pública, USP]. $37 \mathrm{p}$.

CHOMEL, B.B. The modern epidemiological aspects of rabies in the world. Comp. Immun. Microbiol. Infect. Dis. 16(1): 11-20, 1993.

CHOMEL, B.; CHAPPUIS, G.; BULLON, F.; CARDENAS, E.; BEUBLAIN T.D. DE; MAUFRAIS, M.C.; GIAMBRUNO, E. Serological results of a dog vaccination campaign against rabies in Peru. Rev. sci. tech. Off. int. Epiz., 6(1): 97-113, 1987.

CHOMEL, B.; CHAPPUIS, G.; BULLON, F.; CARDENAS, E.; BEUBLAIN, T.D.; LOMBARD, M. AND GIAMBRUNO, E. Mass vaccination campaign against 
rabies: are dogs correctly protected ? The Peruvian experience. Reviews of Infectious Diseases, 10 (suppl. 4): 697-702, 1988.

CIFUENTES, E.E. Program for the elimination of urban rabies in Latin America. Reviews of infectious diseases, 10(suppl.4):689-692, 1988.

CLARK, K.A.; KELLY, V.P.; NEWMAN, E.C.; BILDERBACK, W.R.; NETTLES, W.D.; RHODES, T.S. Rabies vaccination. Field observation during epizootics in dogs. Modern Veterinary Practice, dec.: 907-911, 1981.

COLEMAN, P.G.; DYE, C. Immunization coverage required to prevent outbreks of dog rabies. Vaccine, 14(3): 185-186, 1996.

COMAN, B.J.; ROBINSON, J.L. Some aspects of stray dog behavior in an urban fringe area. Australian Veterinary Journal, 66(1): 30-32, 1989.

COOK, G.C. Canine-associated zoonoses: an unacceptable hazard to human health. Quarterly Journal of Medicine, New Series, 70(261): 5-26, 1989.

CORREAA, W.M.; CORREAA, C.N.M. Enfermidades infecciosas dos mamíferos domésticos. Rio de Janeiro, MEDSI, 1992. 843p.

COYNE, M.J.; SMITH, G.; MCALLISTER, F.E. Mathematical model for the population biology of rabies in raccoons in the mid-Atlantic states. American Journal of Veterinary Research, 50 (12): 2148-2154, 1989.

DAVIS, S.J.M; VALLA, F.R. Evidence for domestication of the dog 12,000 years ago in the Natufian of Israel. Nature, 276(7): 608-610, 1978.

DELLLEPIANE, N.I.; DIAZ, A.M. La rabia. II. Situacion epidemiologica en las Americas. Vacunas e inmunidade. Revista Argentina de Microbiologia, 19: 125$138,1987$.

DELGADO, S.; CÁRMENES, P. Immune response follwing a vaccination campaign against rabies in dogs from northwestern Spain. Preventive Veterinary Medicine, 31:257-261, 1997.

DELPIETRO, H; SEGRE, L.; MARCHEVSKY, N.; BERISSO, M. [Rabies transmission to rodents after ingestion of naturally infected tissues].[Article in Spanish] Medicina (Buenos Aires) 50(4): 356-60, 1990. [Abstract in PubMed].

ENG, T.R.; FISHBEIN, D.B. Epidemiologic factors, clinical findings, and vaccination status of rabies in cats an dogs in the United States in 1988. JAVMA 197(2): 201-209, 1990. 
ENG, T.R.; FISHBEIN, D.B.; TALAMENTE, H.E. et al. Urban epizootic of rabies in Mexico: epidemiology and impact of animal bite injuries. Bulletin of the World Health Organization, 71(5): 615-624, 1993.

ENG, T.R.; FISHBEIN, D.B.; TALAMANTE, H.E. et al. Immunogenicity of rabies vaccines used during an urban epizootic of rabies in Mexico. Vaccine, 12 (14): 1259-1264, 1994.

ERNST, S.N. Epidemiology of rabies in Chile, 1950-1986: a descriptive study of laboratory - confirmed cases. Rev. microbiol, SP, 20(1): 121-127, 1989.

ERNST, S.N.; FABREGA, F. A time series analysis of the rabies control programme in Chile. Epidemiology and infection, 103(3): 651-657, 1989.

FEKADU, M. Pathogenesis of rabies virus infection in dogs. Reviews of infectious diseases, 10(suppl.4): 678-683, 1988.

FEKADU, M.; SHADDOCK, J.H. Peripheral distribution of virus in dogs inoculated with two strains of rabies virus. American Journal of Veterinary Research, 45(4): 724-729, 1984.

FEKADU, M.; SHADDOCK, J.H.; BAER, G.M. Intermittent excretion of rabies virus in the saliva of a dog two and six months after it had recovered from experimental rabies. American Journal of Tropical Medicine and Hygiene, 30(5): 1113-1115, 1981.

FEKADU, M.; NESBY, S.L.; SHADDOCK, J.H.; SCHUMACHER, C.L.; LINHART, S.B.; SANDERLIN, D.W. Immunogenicity, efficacy and safety of an oral rabies vaccine (SAG-2) in dogs. Vaccine, 14(6): 465-468, 1996.

FELDMANN, B.M. The problem of urban dogs. Science, 185(4155): 903.

FERNÁNDEZ, M.; GIL, H.R. I seminario nacional sobre rabia. Situacion Epidemiologica de la rabia humana y canina en Venezuela. Revista del Instituto Nacional de Higiene, VIII(3-4): 133-137, 1975.

FIELDS, M.; AMENT, R.D.; LAMB, D.; BLADES, J. Suckling-mouse-brain rabies vaccine (SMBV): duration of immunity in dogs. Veterinary Medicine / Small animal clinician, jan, 37-40, 1976.

FORATTINI, O. P. Ecologia, Epidemiologia e Sociedade. São Paulo: Artes Médicas: Editora da Universidade de São Paulo, 1992. 
FRANTI, C.E.; KRAUS, J.F.; BORHANI, N.O. Pet ownership in a suburban-rural area of California, 1970. Public Health Reports, 89(5): 473-484, 1974.

FRASER, G.C.; HOOPER, P.T.; LUNT, R.A.; GOULD, A.R., GLEESON, L.J.; HYATT, A.D.; RUSSELL, G.M.; KATTENBELT, J.Á. Encephalitis caused by a Lyssavirus in fruit bats in Australia. Emerging Infectious Diseases 2(4):327-31, 1996. [Abstract in PubMed]

FRONTINI, M.G.; FISHBEIN, D.B.; RAMOS, J.G.; et al. A field evaluation in Mexico of four baits for oral rabies vaccination of dogs. Am. J. Trop. Med. Hyg. 47(3): 310-316, 1992.

FU, Z.F. Rabies and rabies research: past, present and future. Vaccine, 15: s20-s24, 1997.

GARNIER, M.; DELAMARE, V. Dicionário de termos técnicos em medicina. São Paulo, $20^{\mathrm{a}}$ edição, Organização Andrei Editora Ltda., 1984.

GERMANO, P.M.L.; ISHIZUKA, M.M.; NILSSON, M.R.; MIGUEL, O. Avaliação da resposta imunitária da vacina anti-rábica preparada em cérebros de camundongos lactentes aplicadas em cães primovacinados, em condições naturais. Revista da Faculdade de Medicina Veterinária e Zootecnia da Universidade de São Paulo, 19(1): 67-73, 1982.

GOMES, F.J.P. Programa Nacional de Profilaxia da Raiva. Consideraçães sobre o seu desenvolvimento, 1975-1978. Revista da Fundação Sesp, 25(1): ___, 1980.

GOMES, F.J.P. Programa nacional de controle da raiva no Brasil. Revista da Fundação Sesp, 28(2): 165-175, 1983.

GOMES, F.J.P. Programa nacional de profilaxia da raiva. Relatório preliminar 1984. Arq. Biol. Tecnol., 28(2): 319-325, 1985.

GOULD, A.R.; HYATT, A.D.; LUNT, R.; KATTENBELT, J.A.; HENGSTBERGER, S.; BLACKSELL, S.D. Characterisation of a novel lyssavirus isolated from Pteropid bats in Australia. Virus Res. 54(2): 165-87, 1998. [Abstract in PubMed]

GUIDOLIN, R.; BALTAZAR, M.C.; ZELANTE, F. Produção da vacina anti-rábica veterinária em suspensão de células BHK. Revista de Microbiologia, SP, 14(1): 27-35, 1983. 
HADDAD, N.; KHARMACHI, H.; BEN OSMAN, F. Programme de lutte contre la rage canine en Tunisie. Perspectives de lutte contre la rage du chien errant. Bull. Acad. Vét. de France, 61: 395-401, 1988.

HAYASHI, Y.; MORA, E.; CHANDELIER, E.L.; MONTAÑO, J.A.; OHI, M. Estudos de proteção cruzada de 24 cepas de vírus rábico isoladas de diferentes espécimes animais no Brasil. Arq. Biol. Tecnol., 27(1): 27-35, 1984.

HAYASHI, Y.; MORA, E.; MONTAÑO, J.A.; OHI, M. Suckling mouse brain rabies vaccine: some observations on its production and applications after 30 years (1954-1984) of its development by Fuenzalida \& Palacios. Arq. Biol. Tecnol., 28(2): 245-256, 1985.

HAYASHI, Y.; MONTAÑO, J.A.; MORA, E. Situacion de la rabia humana y canina en Brasil - 1984. Arq. Biol. Tecnol., 29(4): 553-570, 1986.

HIRAYAMA, N.; JUSA, E.R.; NOOR, M.A.R.; SAKAKI, K.; OGATA, M. Immune state of dogs injected with rabies vaccines in the west Java, Indonesia. Jpn. J. Vet. Sci., 52(5): 1099-1101, 1990.

IBGE. Sinopse preliminar do censo demográfico - 1991. Número 12 - Pernambuco. Rio de Janeiro, 6: 1-91, 1991. (Secretaria de planejamento, orçamento e coordenação. Fundação Instituto Brasileiro de Geigrafia e Estatística - IBGE)

ITO, F.H.; VASCONCELLOS, S.A.; ERBOLATO, E.B.; MACRUZ, R.; CÔRTES, J.A. Rabies virus in different segments of brain and spinal cord of naturally and experimentally infected dogs. International Journal of Zoonoses, 12: 98-104, 1985.

JAVADI, M.A.; FAYAZ, A.; MIRDEHGHAN, S.A.; AINOLLAHI, B . Transmission of rabies by corneal graft. Cornea 15(4):431-3, 1996. [Abstract in PubMed].

JOHNSON, H.N. Experimental studies on the duration of immunity in dogs vaccinated against rabies. Bulletin of the World Health Organization, 10:725$729,1954$.

KALTON, G. Introduction to survey sampling. Series: quantitative applications in the social sciences, $\mathrm{n}^{\circ} 35$, Sage University Paper, 1983, $96 \mathrm{p}$.

KAZMIER, L. J. Estatística aplicada à economia e administração. São Paulo, Ed. McGraw-Hill, 1982. (p. 328-345) 
KENNEDY, D.J. An outbreak of rabies in north-western Zimbabwe, 1980 to 1983. The Veterinary Record, 122: 129-133, 1988.

KONOLSAISEN, J.F. Estado atual da profilaxia da raiva no Paraná. Arq. Biol. Tecnol., 28(2): 307-312, 1985.

LARGHI, O.P.; ARROSSI, J.C.; CETRÁNGOLO, R.; DÍAZ, A.M.; ELBERGER, D.; JUAN, N. Levels of vaccine potency used in the successful control of rabies in Buenos Aires, Argentina. J. Vet. Med., B, 33: 389-392, 1986.

LAURENTI, R.; MELLO JORGE, M.H.P.; LEBRÃO, M.L.; GOTLIEB, S.L.D., Estatísticas de Saúde, 2 ed., São Paulo, E.P.U., 1987.

LIECHTI, Z.L. Vacinação anti-rábica humana. Aspectos epidemiológicos. Arq. EMV-UFBA, 7(1): 41-55, 1982.

LIECHTI, Z; LOUREIRO, S. Estudo epidemiológico da exposição humana a animais supostamente raivosos em Salvador, Bahia. Arq. EMV-UFBA, 4(1): 133 $152,1979$.

LIECHTI, Z.; LOUREIRO, S. Avaliação do Programa Nacional de Profilaxia da Raiva (PNPR) em centro de saúde, em Salvador-Bahia. Arq. EMV-UFBA, 7(1): 56-81, 1982.

MÁlAGA, H.; RODRÍGUEZ, J.; INOPE, L.; TORRES, J. Epidemiologia de la rabia canina en Lima Metropolitana. Boletin de la Oficina Sanitaria Panamericana, nov: 405-413, 1976.

MÁlAGA, H.; LOPEZ NIETO, E; GAMBIRAZIO, C. International Journal of Epidemiology, 8(3): 243-245, 1979.

MARTINS, E. DESENVOLVIMENTO HUMANO NO BRASIL. [programa de computador]. Versão 1.0. Belo Horizonte(MG): ESM Consultoria / PNUD / IPEA / FJP; 1998.

MASSAD, E.; BURATTINI, M.N.; AZEVEDO NETO, R.S. de; et al. A modelbased design of a vaccination strategy against rubella in a non-immunized community of São Paulo State, Brazil. Epidemiol. Infect., 112: 579-594, 1994.

MASSON, E.; CLIQUET, F.; AUBERT, M.; BARRAT, J.; AUBERT, A.; ARTOIS, M.; SCHUMACHER, C.L. Safety study of the SAG-2 rabies virus mutant in several non-target species with a view to its future use for the immunization of foxes in Europe. Vaccine, 14(16): 1506-1510, 1996. 
MEISNER, F.L.; DAVIS, R.D.; BROWN, M.K.; RUPPRECHT, C.E.; SMITH, J.S.; BRIGGS, D.J. Rabies serological testing in dogs and cats exported to rabies-free countries: does the choice of test make a difference ? United States Animal Health Association WEB, [online Proceedings] 1997:[7 screens]. Available from: <URL: http://www.usaha.org/speeches/rtest97.htmi> [ 1999 Jan 14]

MERRY, D.L.; BROWN, A.L.; BECKENHAUER, W.H. Subcutaneous vs. Intramuscular inoculation of dogs. Veterinary Medicine / Small Animal Clinician, aug, 675-679, 1969.

MONTEIRO, J.M.; PRETO, A.A.; SPRADA, E.R.; GERMANO, P.M.L. Perfil da raiva animal em Curitiba e Área Metropolitana durante o período de 1955 a 1989. Arq. Biol. Tecnol., 35(1): 23-35, 1992.

MOREIRA, E.C.; GONTIJO, M.T.; CASTRO, A.; REIS, R.; VIANA, F.C.; MOREIRA, W.L. Aspectos epidemiologicos del tratamiento antirrabico humano en Belo Horizonte, Minas Gerais, Brasil. Bol. Of. Pan. Saude, jan: 38-44, 1976.

MULLER-HOLVE, W.; LEITRITZ, H.; KNORR, E. [Early development of a child following rabies of the mother during pregnancy].[Article in German] Infection 5(1):49-50, 1977. [Abstract in PubMed].

NAGATA, C.A.; LIMA, M.C.L.F.; LUARCA, E.G. Avaliação laboratorial da raiva urbana em Salvador (1968-1977). Arq. EMV-UFBA, 5(1): 35-45, 1980.

NARAYAN, K.G. Urban dog rabies endemicity and dog physiology. International Journal of Zoonoses, 12: 22-27, 1985,

NASSAR, R.; MOSIER, J.E. Canine population dynamics: a study of the Manhattan, Kansas, canine population. American Journal of Veterinary Research, 41(11): 1798-1803.

NUNES, C.M.; MARTINES, D.A.; FIKARIS, S.; QUEIRÓZ, L.H. Avaliação da população canina da zona urbana do município de Araçatuba, São Paulo, SP, Brasil. Revista de Saúde Pública, 31(3): 308-309, 1997 (Notas e Informações).

OBOEGBULEM, S.I.; NWAKONOBI, I.E. Population density and ecology of dogs in Nigeria: a pilot study. Rev. sci. tech. Off. int. Epiz., 8(3): 733-745, 1989. 
O.I.E. Rabies. [online International Animal Health Code] 1998; Chapter 3.1.5.: [8 screens] Available from: <URL: http://www.oie.int/Norms/Mcode/ A_00047.htm> [ 1999 Jan 14]

OKOH, A.E.J. Canine rabies in Nigeria, 1970-1980 reported cases in vaccinated dogs. International Journal of Zoonoses, 9: 118-125, 1982.

OKOLO, M.I.O. Dubm (paralytic) rabies in dogs in Nigeria. International Journal of Zoonoses, 13: 11-18, 1986.

OPS. Plan de accion para la consolidacion de la fase de ataque final para la eliminacion de la rabia en las Americas - 1993-2000, 1993.

OSMAN, F.B.; HADDAD, N. Experience in field rabies control programs. Reviews of infectious diseases, 10 (suppl.4):703-706, 1988.

PERRIN, P.; MADHUSUDANA, S.; GONTIER-JALLET, C.; et al. An experimental rabies vaccine produced with a new BHK-21 suspension cell culture process: use of serum-free medium and perfusion-reactor system. Vaccine, 13(13): 1244-1250, 1995.

PERRY, B.D.; BROOKS, R.; FOGGIN, C.M.; BLEAKLEY, F.; JOHNSTON, D.H.; HILL, F.W.G. A baiting system suitable for the delivery of oral rabies vaccine to dog populations in Zimbabwe. Veterinary Record, 123: 76-79, 1988.

PINTO, C.L.; ALLEONI, E.S. Aspectos da vigilância epidemiológica da raiva em sub-regiões administrativas do estado de São Paulo, Brasil, 1982-1983._Revista de Saúde Pública, SP, 20(4): 288-292, 1986.

PNUD. Programa de las Naciones Unidas para el Desarrollo. República Argentina. [report online] 1996: [3 screens]. Available from: <URL: http: //www .undp.org.ar/desarro.htm> [ 1999 Jan 19]

PNUD. Relatório do desenvolvimento humano [report online] 1997: [5 screens]. Available from: <URL: http://Www. undp.org.br/rdh7-2.html> [ 1999 Jan 19]

PRESSNALL, C.C. Controle de los animales silvestres vectores de rabia a lo largo de la frontera mexicano-estadunidense. Boletin de la Oficina Sanitaria Panamericana, 43 (2): 159-162, ago., 1957. 
RAJAN, T.S.S.; SUNDARARAJ, A.; PATTABIRAMAN, S.R. Clinico epizootiological observation on canine rabies. Indian vet. J., 67: 1163-1166, 1990.

RECIFE. Código Municipal de Saúde. Lei no 16.004 de 20/01/1995. Título V Populações animais, zoonoses e outros controles. Capítulos I e II.

ROQUAYROL, M.Z. Epidemiologia \& Saúde. Rio de Janeiro, ed. Medsi, $3^{\mathrm{a}}$ ed., 1988. $492 \mathrm{p}$.

ROCHA, L.A. Aspectos da evolução da profilaxia da raiva em Pernambuco. Recife, 1955. [Tese para concurso de docência-livre da cátedra de higiene da Faculdade de Medicina da Universidade de Recife]. 75 p.

RUPPRECHT, C.E.; HANLON, C.A.; SHADDOCK, J.S.; SANDERLIN, D.W.; ORCIARI, L.; NIEZGODA, M.; YAGER, P.; BERTHON, A.; AUBERT, A Safety and efficacy of an oral SAG2 rabies virus vaccine in dogs. In: IX Reunion internacional sobre avances en la investigacion y control de la rabia en las Americas. 1998 diciembre 8-12. Puerto Vallarta, Mexico. 1998. p. 42.

SÃO PAULO. Norma técnica: profilaxia da raiva em humanos. Secretaria de Estado da Saúde, Comissão Técnico-Científica de Controle da Raiva, 1994, 20p.

SCHLOGEL, F.; MONTEIRO, J.M.; WARTELSTEINER, E.M.; KUROWSKI, U.M. Raiva canina e felina no Paraná. Arq. Biol. Tecnol. 28(2): 265-276, 1985.

SCHNEIDER, M.C. Estudo de avaliação sobre área de risco para raiva no Brasil Rio de Janeiro, 1990. [ Dissertação de Mestrado da ENSP / FIOCRUZ] 230 p.

SCHNEIDER, M.C.; ALMEIDA, G.A.; SOUZA, L.M.; MORARES, N.B.; DIAZ, R.C. Controle da raiva no Brasil de 1980 a 1990. Revista de Saúde Pública, 30(2): 196-203, 1996.

SIEGEL, S. Estatística não-paramétrica para ciências do comportamento. São Paulo, McGraw-Hill, 1975. 350 p.

SIKES, R.K. Canine and feline vaccines - Past and present. In: Baer, G.M., ed. The Natural History of Rabies, New York, Academic Press, 1975. p. 177-187.

SIKES, R.K.; PEACOCK, G.V.; ACHA, P.; ARKO, R.J.; DIERKS, R. Rabies vaccines: duration-of-immunity study in dogs. Jounal of the American Veterinary Medical Association, 159(11): 1491-1499, 1971. 
SILVA, L.H.Q.; ITOYAMA, C.T.; BRITTES, A.S. Pesquisa de anticorpos antirábicos em cães de área de foco no município de Araçatuba, SP. A Hora Veterinária, 16(93): 55-57, 1996.

SILVA, N.N. Amostragem Probabilística: um Curso Introdutório. São Paulo: Edusp; 1998.

SIPAHIOGLU, U.; ALPAUT, S. [Transplacental rabies in humans]. [Article in Turkish] Mikrobiyol. Bul. 19(2):95-9, 1985. [Abstract in PubMed].

SMITH, A.D.M. A continuous time deterministic model of temporal rabies. In: Philip. J. Bacon, ed., Population Dynamics of Rabies in Wildlife, Academic Press; 1985. p. 131-146.

SMITH, J.S.; SEIDEL, H.D. Rabies: a new look at an old disease_ Progress in Medical Virology, 40: 82-106, 1993.

SMITH, J.S.; YAGER, P.A.; BAER, G.M. A rapid reproducible test for determining rabies neutralizing antibody. Bulletin of the World Health Organization, 48: 535$541,1973$.

SMITH, J.S.; YAGER, P.A.; BAER, G.M. A rapid fluorescent focus inhibition test (RFFIT) for determining rabies virus-neutralizing antibody. In: F.-X.Meslin, F.X.; Kaplan, M.M.; Koprowski, H., ed. Laboratory techniques in rabies, 4th ed., Geneva, World Health Organization, 1996. p. 181-192.

SOARES, I.C.G.; SOUZA, M.M.; LEMOS, H.N.; SERUFO, J.C.; ABREU, V.L.V.; REIS, W.; DE CAMPOS, H.H.V. Immunization for dog rabies. Arq. Biol. Tecnol., 35(1): 139-151, 1992

SOUTO MAIOR, M.; SILVA, L.D. O RECIFE, quatro séculos de sua paisagem.

Recife, FUNDAJ, Editora Massangana; PCR/SEC, 1992.

STEVENSON, W.J. Estatística aplicada à administração. São Paulo, ed. HARBRA Ltda, 1986. 495p.

STEELE, J.H. History of rabies. In: Baer, G.M., ed. The Natural History of Rabies, New York, Academic Press, 1975. p. 1-29.

SUMMA, M.E.L.; CARRIERI, M.L.; FAVORETTO, S.R.; CHAMELET, E.L.B. Rabies in the State of São Paulo: the rodents question. Rev. Inst. Med. Trop. São Paulo, 29(1): 43-58, 1987. 
[anonymus] THE AMERICAN HERITAGE DICTIONARY [CD ROM. Copyright (O) 1994 Softkey International Inc.] Third Edition version 3.6a. Para Windows e Macintosh, HOME PC, Editora Abril.

THRUSFIELD, M. Veterinary Epidemiology. London, Butterworth \& Co. (Publishers) Ltd, 1986.

TIMENETSKY, J.; CHAMELET, E.L.B.; MENDES, N.F.; PEREIRA, O.A.C. Cell mediated immune response in canine antirabies vaccination. Revista do Instituto de Medicina Tropical de São Paulo, 27(1): 1-5, 1985.

TORDO, N. Characteristics and molecular biology of the rabies virus. In: F.X.Meslin, F.-X.; Kaplan, M.M.; Koprowski, H., ed. Laboratory techniques in rabies, 4th ed., Geneva, World Health Organization, 1996. p. 28-51.

TORNERO, N.L.; SHIBAYAMA, K.K. Avaliação de um serviço de rotina (vacinação anti-rábica) no centro de saúde de Londrina, Paraná, Brasil. Revista de Saúde Pública, SP. 8: 359-367, 1974.

TORRES, J.G.R. Rabia en la frontera norte de Mexico, 1969-1979. Bol. Of. Sanit. Panam., 93(2): 142-148, 1982.

VIEIRA, S. Introdução à Bioestatística, Rio de Janeiro, ed. Campus, $6^{\mathrm{a}}$ reimpressão, 1989. $294 \mathrm{p}$.

VOS, A.; AYLAN, O.; NEUBERT, A.; GUZEL, N. A mass dog vaccination campaign including oral vaccination with SAD B19 in Turkey. In: IX Reunion internacional sobre avances en la investigacion y control de la rabia en las Americas. 1998 diciembre 8-12. Puerto Vallarta, Mexico. 1998. p. 42.

WALTNER-TOEWS, D.; MARYONO, A.; AKOSO, B.T.; WISYNU, S.; UNRUH, D.H.A. An epidemic of canine rabies in Central Java, Indonesia. Preventive Veterinary Medicine, 8: 295-303, 1990

WANDELER, A. I; MATTER, H.C.; KAPPELER, A; BUDDE, A. The ecology of dogs and canine rabies: a selective review. Rev. Sci. Tech. Of. Int. Epiz., 12 (1): 51-71, 1993.

WANDELER, A. I. et al., Dog ecology and dog rabies control. Reviews of Infectious Diseases, 10 (suppl. 4): S684-S688, 1988. 
WASI et al. Progress and achievement of rabies control in Thailand Vaccine 15(suppl.): s7-s11, 1997.

WHITBY, J.E.; JOHNSTONE, P.; PARSONS, G.; KING, A.A.; HUTSON, A.M. Ten-year survey of British bats for the existence of rabies. Veterinary Record 139(20):491-3, 1996.

WHO. Dog rabies elimination. A trend analysis and programme proposal prepared by a WHO Working Group. International Journal of Zoonoses, 9: 97-112, 1982.

WHO. Guidelines for dog rabies control , 1987. [WHO / VPH / 83.43 Rev. 1]

WHO. Report of WHO consultation on dog ecology studies related to rabies control, 1988. [WHO / Rab.Res./88.25]

WHO. Guidelines for dog population management, 1990. [WHO / ZOON / 90.165]

WHO. WHO expert committee on rabies, 1992. [WHO technical report series no. 824 , eight report, Geneva, Switzerland, 87 p.]

WHO. Laboratory techniques in rabies, ed. Meslin, F.-X.; Kaplan, M.M.; Koprowski, H. 4th ed., Geneva, World Health Organization, 1996. 


\section{ANEXOS}




\subsection{ANEXO I - Definição operacional das variáveis utilizadas no trabalho}

- abundância de cães: quantidade de cães num local em particular, considerada em termos absolutos e em relação ao número de pessoas, em relação a uma unidade de área, ou em relação a outros parâmetros que resultem em indicadores úteis.

- acessibilidade dos cães: define a percentagem de cães em uma dada população, a qual pode ser apanhada por uma pessoa sem esforço especial - (i) quando domicílios de referência podem ser identificados, (ii) quando colar ou outras marcas indicam responsabilidade pela propriedade do cão, (iii) quando os cães reagem amigavelmente ao toque de um estranho (p.e., o entrevistador). (WHO/Rab.Res./88.25, pág. 10).

- acesso dos cães ao ambiente extra-domiciliar: avaliado pela possibilidade e freqüência de saída do cão do ambiente domiciliar, com ou sem a supervisão direta de uma pessoa.

- áreas de risco de raiva: refere-se a áreas onde existem uma ou mais condições que favorecem à ocorrência e / ou manutenção da raiva, quais sejam elevada densidade canina, elevada proporção de animais suscetiveis, elevada proporção de animais não restritos, dentre outras.

- atitudes das pessoas em relação aos cães, controle da população de cães através da captura e eliminação dos cães errantes, e campanhas de vacinação: tratase das informações fornecidas pelas pessoas entrevistadas no que diz respeito aos motivos de criar ou não cães, cuidados a eles dispensados, em especial no que diz respeito às medidas de prevenção da raiva, opinião sobre o trabalho da "carrocinha", vacinação ou não dos cães contra a raiva, e participação ou não de campanhas públicas de vacinação, com os motivos referidos.

- cão errante: o termo "cão errante"(do inglês 'stray dog') deve ser reservado exclusivamente para definir o cão que não está de acordo com os requerimentos reguladores locais, p.e., medidas veterinárias para controle de raiva tal qual confinamento, uso de coleira, imunização, etc. (WHO/Rab.Res./88.25, pág. 11). 
- características reprodutivas: relaciona-se à situação reprodutiva de um cão em particular, como p.e. se uma cadela já teve cria, se é gestante, se está com filhotes ou não mais está apta para a reprodução.

- categoria de cães: em número de cinco, resulta da combinação das variáveis dependência e restrição dos cães. Tal combinação resultaria em 9 categorias de cães, mas algumas delas não existem em termos práticos, p.e., cães completamente dependentes e não restritos (WHO/Rab.Res./88.25, pág. 13).

São as seguintes as categorias de cães:

1) Restrito (supervisionado): completamente dependente e completamente restrito.

2) Cão familiar: completamente dependente, semi-restrito.

3) Cão de vizinhança: semi-dependente, semi-restrito.

4) Não restrito: semi-dependente, não restrito.

5) Cão "selvagem" (do inglês "feral"): independente, não restrito.

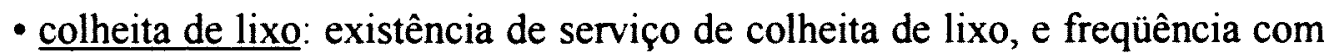
que o mesmo é realizado.

- estado de vacinação dos cães contra a raiva: informação de que o animal recebeu ou não vacina contra a raiva, e há quanto tempo, fornecida por moradores do domicílio do cão.

- funcões dos cães para os homens: refere-se ao motivo de possuir um cão em particular, apontado pelo entrevistado, como por exemplo, criar cães para guarda, como animal de estimação ou companhia, para comercialização (reprodução), dentre outros.

- instrução (escolaridade): escolaridade do chefe da família, representada pela atual formação escolar da pessoa, condição de alfabetização e anos de estudo.

- mortalidade: resultante da informação de mortes fornecidas pelas pessoas entrevistadas, conhecida a estimativa do tamanho da população de estudo. Pode ser estimada indiretamente, a partir da estimativa do crescimento populacional intrinseco. 
- dependência: refere-se à dependência dos cães quanto a cuidados fornecidos intencionalmente: alimento, abrigo, saúde, necessidades sociais. A dependência pode ser classificada em completa, parcial ou nenhuma. No estudo será avaliado se o cão recebe alimento no domicílio, se lá ele é abrigado, se recebe vacinação contra a raiva e assistência veterinária.

- $\underline{\text { restrição: }}$ refere-se à restrição imposta ao cão intencionalmente pelos humanos. A restrição pode ser classificada em completa, parcial ou nenhuma.

- origem dos cães: refere-se à procedência do animal, se ele nasceu no próprio domicílio, se foi comprado, se foi presenteado, se era um cão de rua que foi adotado, dentre outras.

- renda per capta familiar: somatório da renda das pessoas que constituem um domicílio em particular, dividido pelo respectivo número de pessoas.

- renovação populacional: é o resultado dos processos de entrada e saida de cães em uma população em particular, resultante sobretudo dos fatores natalidade $\mathrm{e}$ mortalidade.

- saneamento básico: condições de saneamento de um domicílio em particular.

- taxa de natalidade: resultante da informação de nascimentos fornecidas pelas pessoas entrevistadas, conhecida a estimativa do tamanho da população de estudo.

- tipo de domicílio: refere-se à classificação do domicílio em tipos úteis para os propósitos do estudo. 


\subsection{ANEXO II - Fórmulas para determinação do tamanho da amostra, objetivando a estimativa de médias e proporçōes populacionais (Stevenson, 1986)}

a) Estimativa de proporção:

$$
\mathrm{n}=\mathrm{z}^{2}\left[\mathrm{p}(1-\mathrm{p}) / \mathrm{e}^{2}\right]
$$

onde:

$\mathrm{n}=$ tamanho da amostra

$\mathrm{z}=$ desvio padrão normal

$\mathrm{p}=$ proporção populacional estimada que apresenta a característica em estudo

( 1-p ) = complemento de $p$, ou seja, é a fração remanescente da população que não apresenta a característica em estudo.

e $=$ erro tolerável.

Para a determinação do tamanho amostral mínimo a ser utilizado no estudo, foram utilizados os seguintes valores: $z=1,96$ (correspondente ao nível de confiança de $95 \%$ ); $p=$ 0,50 ( $\mathrm{P}$ máximo, considerando desconhecidas as proporções das características a serem estudadas), além de $e=0,05$. Obtém-se então:

$$
\mathbf{n}=1,96^{2}\left[0,50(1-0,50) / 0,05^{2}\right]=384
$$

b) Estimativa de Média:

$$
n=\left[z\left(s_{x} / e\right)\right]^{2}
$$

onde:

$\mathrm{n}=$ tamanho da amostra

$\mathrm{t}=$ desvio padrão da distribuição $\mathrm{t}$ (próximo a $\mathrm{z}$, para valores de $\mathrm{n}$ grandes)

$\mathrm{s}_{\mathrm{x}}=$ desvio padrão da amostra, em substituição ao desvio padrão populacional

e $=$ erro tolerável

A quantidade de cães que se espera obter na amostra, permitirá a realização de estimativas de algumas importantes médias para a investigação, com os seguintes erros, aproximadamente, considerando valores obtidos num estudo realizado em Recife no ano de 1993 e o nível de confiança de $95 \%$ :

e $<0,20$ pessoas por domicílio com cão

$\mathrm{e}<0,15$ pessoas por domicílio em geral 
e $<0,15$ cães por domicílio com cão

e $<2,0$ meses para a idade média à primeira vacinação contra raiva

e $<2,5$ meses para a idade média dos cães

Para exemplificar: encontrando-se uma proporção de domicílios com cães variando entre $37,5 \%$ e $42,5 \%$, uma média de cães por domicílio com cães variando entre 1,725 e 1,875 , em uma cidade com 345.000 domicílios, tendo em média 4,5 habitantes por domicílio, estimaríamos, para a cidade, 1.552 .500 habitantes, 223.172 a 274.922 cães, e uma razão habitantes : cães entre 6.96 e 5.65, amplitude esta aparentemente satisfatória. 


\subsection{Anexo III - Questionário da CAMPANHA DE VACINAÇÃO ANTI-RÁBICA DA CIDADE DO RECIFE}

NOME DO SUPERVISOR

REGIONAL: BAIRRO

POSTO

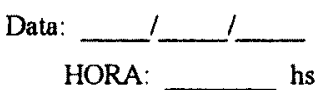

(Para qualquer item ou sub item desconhecido, preencha com interrogação, se não houver outra opção. Traço(-) para valor zero)

1) IDENTIFICAÇÃO: () cão () gato / () Masc. () Fem. / Raça

2) Idade do dono ? () criança/jovem < 17 anos () adulto ou jovem $>17$ anos () é de todos () não sabe

3) Qual a função dele? () estimação () guarda () caça () reprodução () outros () não sabe

4) Já teve cio ou cruzou ? () sim () nào / Quantas vezes pariu até hoje ?__ Quantos filhotes até hoje ?

5) $\mathrm{O}$ animal está gestante? () sim () não/Quantas vezes pariu últ. 12 meses ? _ Quantos fillhotes $12 \mathrm{~m}$ ?

6) Qual é a idade do seu animal ? __ anos, e __ meses

() não sabe idade (indique então Filhote [até 3 meses], Jovem [<1 ano], ou Adulto )

7) É A PRIMEIRA VEZ QUE ELE E VACINADO CONTRA RAIVA ?

() $\operatorname{sim}$ () não () não sabe Se a resposta é não, quantas vezes já foi vacinado ?

8) QUANTOS OUTROS ANIMAIS VOCE TEM EM CASA (Na casa do animal: indicar por sexo)?

() nenhum __ cães __ cadelas ___ filhotes __ gatos __ gatas _ _ gatinhos () não sabe

9) Onde você adquiriu esse cão / ou gato ? () comprou canil () comprou em loja () comprou a outras pessoas

$\begin{array}{lllll}\text { () presente de alguém conhecido () achado na rua () cria propria cadela } & \text { () outros } & \text { () nảo sabe }\end{array}$

9.a) De que local adquiriu ? () Recife () outra cidade, qual ?

10) Quantas pessoas moram na casa do animal ? total _ $0-4 \ldots$ S-10_ 11-17 _ $18-50 \_>50$

11) Quantos cães da casa morreram nos últimos 12 meses? Relacione idades:

12) A SUA CASA (de onde o animal que está sendo vacinado veio) fica a quantos QUARTEIROES deste POSTO ?

$\begin{array}{llllll}\text { () } 1 & \text { () } 2 & \text { () } 3 & \text { () } 4 & \text { () } 5 & \text { () } 6 \text { ou mais quarteirões }\end{array}$ Quantos metros aproximad?

13) COM QUE FREQUÉNCIA ESSE ANIMAL VAI AO VETERINÁRIO ?

(não indicar as alternativas ao entrevistado. Deixar resposta espontânea; indicar item que melhor se enquadre à resposta)

() uma vez ao ano () mais de uma vez ao ano () só quando precisa () nunca foi () não sabe

14) OS SEUS 2 (DOIS) VIZINHOS MAIS PRÓXIMOS CRIAM QUANTOS CÃES OU GATOS ?

(no primeiro vizinho + no segundo vizinho: registrar cada um separadamente; não sabendo de algum, preencher com interrogação)

() nenhum dos dois __ cães __ _ gatos

15) Qual o total de pessoas que moram nas casas de cada um dos dois vizinhos (registrar separadamente) ?

__+ pessoas (no primeirotno segundo vizinho) obs: não sabendo um e/ou outro, use internogação local respec.

16) COMO VOCÊ FICOU SABENDO QUE HOJE É DIA DE VACINAÇÃO?

(não indicar as alternativas ao entrevistado. Deixar resposta espontânea. Pode marcar mais de um item)
() cartazes
() carro de som
() rádio
() $\mathrm{tv}$
() outras pessoas
() outro meio, quais?
// 16.a) Quando ficou sabendo ?

17) VOCÊ SABE O QUE FAZER COM UM ANIMAL SUSPEITO DE RAIVA ?

(não indicar as altemativas ao entrevistado. Deixar resposta espontânea. Pode indicar mais de um item)
() enviar para o canil da Prefeitura
() enviar para o LAPA
() vai ao veterinário
() enviar para a Universidade em Dois Irmãos
() năo sabe

() não apresentou nenhuma destas respostas. Qual ?

18) Você teve alguma dificuldade para trazer o animal para vacinar hoje ? () NÃO () SIM,

Qual ?

19) Você é a favor ou contra o trabalho da CARROCINHA ?
() é a favor
() é contra
() não sabe
() não opinou

20) Você tem alguma SUGESTÃO para MELHORAR (registrar no verso)

21) Conhece alguém que não vacina os próprios cães ou gatos contra raiva ?

() não () sim: Qual o motivo ?

Qual a renda familiar : indique salários minimos ou $\mathrm{R}$ (se aproximada, usar $\operatorname{sinal}>$ ou $<$ ) 


\subsection{AnEXO IV - QUESTIONÁRIO DO DOMICÍLIO}

DATA:
Endereço:
Quem respondeu ? () dono ou dona da casa () outro adulto () jovern, Idade do jovem:
$\begin{array}{lll}\text { (OBS) Tipo de domicilio: () casa independente () casa em área fechada ou semi-fechada comum / condomínio } \\ \text { () apartamento em prédio residencial () apartamento sobre prédio comercial }\end{array}$
$\begin{array}{llll}\text { () barraco de madeira ou barro () cortiço () outros: }\end{array}$

(OBS) Proteção do domicilio: () com muro/grade e portão () com muro/grade, mas sem portão () sem muro/grade e sem portão () cercado que não impede saida do cão () cercado que impede saída do cão () outros:

(OBS) Na chegada ou durante a visita, o portão estava: () aberto () fechado

(OBS) Estado do portão: () não permite a saida do cão () permite a saida do cão por estar quebrado ou com falhas

(OBS) Na chegada ou durante a visita, cães da casa estavam na rua: () sim () não () não há cães

Número de CÃES no DOMICILIO: () nenhum _ fêmeas ad. / jov. _ machos ad./ jov. _ filhotes (até 3 meses) Número de GATOS no DOMICILIO: () nenhum _ fêmeas ad. / jov. — machos ad./ jov. _- filhotes (até 3 meses)

(NT) Se o domicilio não tem căo, já teve antes? () não () sim

(NT) Se o domicilio nåo tem cão, explicar o mottvo: $\quad$ () barulho $\quad$ () sujeira $\quad$ () doenças () despesas

() agressões / mordidas () não gosta de cães () não gosta de animais () outros:

Costuma ver cães sem os donos nas proximidades de casa ? () não () sim Quantos? Da vizinhança Desconhecidos

Cães de fora vêm comer na sua casa ? () sim, alimentados pelos residentes () sim, comem na lixeira da casa, do lado de fora () sim, entram para comer em casa/quintal, mas sem permissão () não

Alguém da casa foi mordido por cães ou outros animais nos últimos 12 meses ? () não () cāes () outros

OBS: se a resposta é sim, preencher questionário de agressões.

Quantos cães você adquiriu nos últimos 12 meses ?

Quantos cães você perdeu, se desfez, deu, etc, nos últimos 12 meses?

Oque ocorreu $\quad$ Indique idades $\quad$ Ouantidade

Ouantos desses cães foram para lugares fora de Recife ?

Quantos desses cães foram para lugares fora de Recife?

Você é a favor ou contra o trabalho da carrocinha ?() é a favor () é contra () não sabe () não opinou

(c) FÊM Quantas vezes as suas cadelas pariram e quantos filhotes tiveram nos últimos 12 meses ?_ ninhadas, __ filhotes

(c) Você vacina os seus animais contra a raiva? () sim () não. Se não, qual o motivo ?

(C, G ) Quando tem campanha em setembro, você leva seus cães (ou gatos, caso nāo tenha ç̄es) para vacinar contra raiva ? () sim () não. Motivo: () distância () medo de o animal pegar doença () não usam seringas descartáveis outros:

(c) Com que freqüência leva os cảes ao veterinário ?
() uma vez ao ane
() mais de uma vez ao ano $<5$ anos $\quad 5-10$ anos

Número de pessoas no domicilio:

O domicilio é próprio ? () sim () năo

Qual o tempo de residência no local?

Colheita de lixo: () diária () mais de uma vez por semana () uma vez por semana () esporúdica, irregular () não há

Onde o lixo é colocado: () local protegido () embalagem não protegida: muro, calçada... () terrenos, córregos, etc. () coletor

A casa tem saneamento? () sim () não

Qual a ocupação do chefe da familia ?

O chefe da familia tem quantos anos de Estudo (ao todo)?

Qual o nivel de instrução do chefe da familia ? () pós-graduado () superior completo () superior inc.

$\begin{array}{llll}\text { () } s e g \text { grau comp. } & \text { () seg. grau inc. } & \text { () prim.grau comp. () prim.grau inc. }\end{array}$

() sem instrução, sabe ler () sem instrução, não sabe ler

Qual a renda familiar:

salários mínimos ou RS (se aproximada, usar sinal > ou $<$ )

PESSOASTEMPO no domicilio:

(todos moraram

durante últ. 12 meses 


\subsection{Anexo V-QUESTIONÁRIO INDIVIDUAL DOS ANIMAIS}

DATA: Entrevistador:

NÚMERO questionário do domicilio:

Quem respondeu ? ( ) dono ou dona da casa ( ) outro adulto ( ) jovem. Idade: ___ anos

Quem é o dono do cão: () homem adulto () mulher adulta () menor de 18 anos. Idade_/E o dono da casa ? S () N ()

Raça:

Sexo: () macho () macho castrado () fêmea () fêmea gestante () rêmea com filhotes () fêmea castrada

Idade atual: anos, meses.

Se Idade ñ̃o precisa, () fllhote até 3 meses () jovem $<1$ ano () adulto

Já teve cio ou cruzou ? () não () sim

Origem do cão: () cria da própria cadela () presente de vixinhos, parentes, etc () comprado em canil
( ) comprado em loja
() comprado de outras pessoas
() achado na rua

() outros:

O cão nasceu em Recife ou em outra cidade ? () Recife () outra cidade Qual cidade ?

$O$ animal foi adquirido com que idade ? ___ anos, ___ meses.
Se idade não precisa,
() Filhote até 3 meses () jovem $<1$ ano
() adulto

Qual a finalidade do cĩo ? () estimação () guarda () estimação/guarda () caça () reprodução () outros () não sabe Onde o cão urina e defeca ?

Ele vai sozinho (se na rua )? () Sim () Não

Como o cão sai de casa ?
() não sai
() com alguém, acorrentado
() com alguém, solto
() só ou c/alguém
() sozinho
() pula muro

Ele pode sair de casa quando quer ? ( ) não ( ) sim

Comumente o cão fica preso: () durante o dia $\begin{array}{lllll}\text { () à noite } & \text { () dia e noíte } & \text { () só as vezes () flca sempre solto }\end{array}$

$O$ cäo permanece de costume:

$\begin{array}{lll}\text { Dentro de casa? } & \text { () } \operatorname{sim} & \text { () não } \\ \text { No canil ? } & \text { () } \operatorname{sim} & \text { () não } \\ \text { Acorrentado jardim/quintal ? () } \operatorname{sim} & \text { () não } \\ \text { Solto no jardim/quintal ? } & \text { () } \operatorname{sim} & \text { () não } \\ \text { Na rua sozinho? } & \text { () } \operatorname{sim} & \text { () não }\end{array}$

Quanto tempo?
Quanto tempo?
Quanto tempo?
Quanto tempo?
Quanto tempo?

Onde o seu cảo se alimenta ? () só em casa () em casa e na rua

() só na rua

Algum vỉinho alimenta cães ? () o cão da pesson entrevistada () outros cães () não

O seu cão também come na rua ? () não () sim Onde ?

Quem trata ou brinca com o cão ? (podem indicar mais de um item)
() dono
() adultos da casa
() crianças da casa
() amigos e vizinhos
() estranhos
() ninguém

$O$ cão é vacinado contra: (pode indicar mais de um item)
() nada
() raiva
() vacina tríplice [cinomose, hepatite canina, leptospirose]
() parvovirose

(SE) Ele é vacinado contra raiva, Quando recebeu a última vacina ?

(SE) Já recebeu vacina contra raiva mais de uma vez ? () não, só uma vez () sim, Quantas ?

(SE) Onde ele foi vacinado? () no posto em campanha () a prefeitura vacinou em casa () veterinário () outros

Obs: (SE) for CADELA, responder perguntas a seguir, CASO CONTRÁRIO, ENCERRAR este questionário. FEM Quantas vezes a cadela pariu até hoje? Quantos filhotes teve até hoje?

FEM Quantas vezes a cadela pariu nos últimos 12 meses?

FÊM Qual foi a data da última cria (se não exata, aproximada)

FÊ Informaçốes sobre a última cria:

nascidos vivos Quantos filhotes nos últ.12 meses?

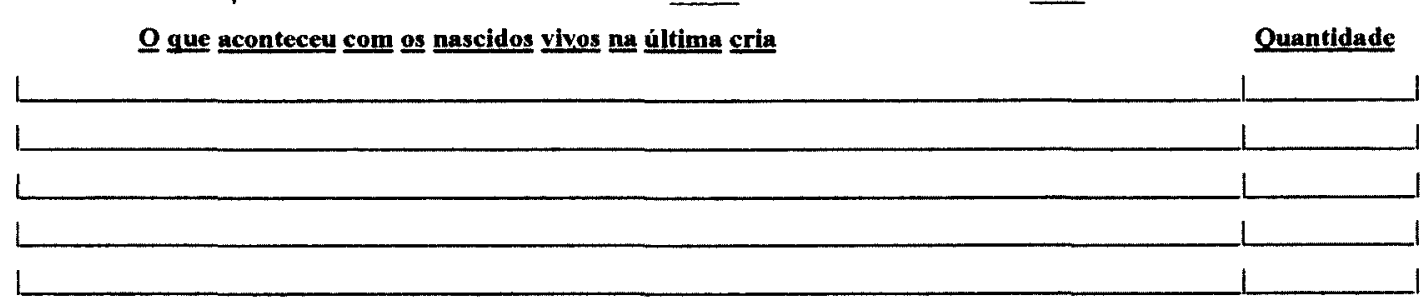




\subsection{Anexo VI-Correlação entre as variáveis censitárias}

Tabela 23: correlação entre as variáveis dependentes e independentes do estudo: coeficiente de correlação (probabilidade <n)

\begin{tabular}{|c|c|c|c|c|c|c|c|c|c|c|c|c|c|c|c|c|c|c|c|c|}
\hline VARIÁVEIS & 1 & 2 & 3 & 4 & 5 & 6 & 7 & 8 & 9 & 10 & 11 & 12 & 13 & 14 & 15 & 16 & 17 & 18 & 19 & 20 \\
\hline 1) Agressóes & 1 & & & & & & & & & & & & & & & & & & & \\
\hline 2) Cria cão & $\begin{array}{c}0,35 \\
(0,05)\end{array}$ & 1 & & & & & & & & & & & & & & & & & & \\
\hline 3) Cão rua & $\begin{array}{c}-0,18 \\
\text { ns } \\
\end{array}$ & $-0,26 \mathrm{~ns}$ & 1 & & & & & & & & & & & & & & & & & \\
\hline 4) Cão Vizinhança & $\begin{array}{r}0,40 \\
(0,05) \\
\end{array}$ & $0,30 \mathrm{~ns}$ & $|-0,30 \mathrm{~ns}|$ & 1 & & & & & & & & & & & & & & & & \\
\hline 5) Cảo solto & $\begin{array}{c}0,37 \\
(0,05) \\
\end{array}$ & \begin{tabular}{|c|}
0,37 \\
$(0,05)$ \\
\end{tabular} & $0,24 \mathrm{~ns}$ & $\begin{array}{c}0,79 \\
(0,01) \\
\end{array}$ & 1 & & & & & & & & & & & & & & & \\
\hline 6) Carrocinha & $-0,07 \mathrm{~ns}$ & $-0,29 \mathrm{~ns}$ & $-0.10 \mathrm{~ns}$ & $0,08 \mathrm{~ns}$ & $0,10 \mathrm{~ns}$ & 1 & & & & & & & & & & & & & & \\
\hline \begin{tabular}{|l|l|l|l|l} 
Căes \\
dependentes
\end{tabular} & $-0,16 \mathrm{~ns}$ & $-0,15 \mathrm{~ns}$ & $0,19 \mathrm{~ns}$ & $\begin{array}{l}-0,69 \\
(0,01)\end{array}$ & $\begin{array}{l}-0,43 \\
(0,01)\end{array}$ & $-0,00 \mathrm{~ns}$ & 1 & & & & & & & & & & & & & \\
\hline 8) Cảes restritos & $-0,27 \mathrm{~ns}$ & $-0,17 \mathrm{~ns}$ & $0,18 \mathrm{~ns}$ & $\begin{array}{r}-0,72 \\
(0,01) \\
\end{array}$ & $\begin{array}{c}-0,51 \\
(0,01)\end{array}$ & $-0,09 \mathrm{~ns}$ & $\begin{array}{c}0,93 \\
(0,01) \\
\end{array}$ & 1 & & & & & & & & & & & & \\
\hline 9) Cães vacinados & $0,07 \mathrm{~ns}$ & $0,18 \mathrm{~ns}$ & $-0,03 \mathrm{~ns}$ & $-0,29 \mathrm{~ns}$ & $\begin{array}{c}-0,40 \\
(0,05) \\
\end{array}$ & $-0,04 \mathrm{~ns}]$ & $0,30 \mathrm{~ns}$ & $0,31 \mathrm{~ns}$ & 1 & & & & & & & & & & & \\
\hline 10) Cria gato & $0,20 \mathrm{~ns}$ & $\begin{array}{c}0,34 \\
(0,05) \\
\end{array}$ & $-0,28 \mathrm{~ns}$ & $\begin{array}{c}0,71 \\
(0,01) \\
\end{array}$ & $\begin{array}{c}0,55 \\
(0,01)\end{array}$ & $0,11 \mathrm{~ns}$ & \begin{tabular}{|l}
$-0,56$ \\
$(0,01)$ \\
\end{tabular} & $\begin{array}{c}-0,63 \\
(0,01)\end{array}$ & $-0,27 \mathrm{~ns}$ & 1 & & & & & & & & & & \\
\hline 11) Área pcf & $-0,23 \mathrm{~ns}$ & $0,23 \mathrm{~ns}$ & $0,11 \mathrm{~ns}$ & $\begin{array}{c}-0,55 \\
(0,01)\end{array}$ & $\begin{array}{c}-0,47 \\
(0,01)\end{array}$ & $-0,04 \mathrm{~ns}$ & $\begin{array}{c}0,43 \\
(0,01) \\
\end{array}$ & $\begin{array}{c}0,44 \\
(0,01) \\
\end{array}$ & $0,21 \mathrm{~ns}$ & $\begin{array}{l}-0,50 \\
(0,01)\end{array}$ & 1 & & & & & & & & & \\
\hline 12) Idade $11-17$ & $-0,21 \mathrm{~ns}$ & $\begin{array}{c}0,39 \\
(0,05) \\
\end{array}$ & $-0,27 \mathrm{~ns}$ & $0,25 \mathrm{~ns}$ & $0,25 \mathrm{~ns}$ & $-0,10 \mathrm{~ns} \mid$ & $-0,04 \mathrm{~ns}$ & $-0,07 \mathrm{~ns}$ & $-0,19 \mathrm{~ns}$ & $\begin{array}{c}0,49 \\
(0,01)\end{array}$ & $-0,21 \mathrm{~ns}]$ & 1 & & & & & & & & \\
\hline 13) Instruçăo & $-0,25 \mathrm{~ns}$ & $-0,19 \mathrm{~ns}$ & $0,12 \mathrm{~ns}$ & $\begin{array}{l}-0,85 \\
(0,01)\end{array}$ & $\begin{array}{l}-0,70 \\
(0,01)\end{array}$ & $-0,07 \mathrm{~ns}$ & $\begin{array}{c}0,76 \\
(0,01) \\
\end{array}$ & $\begin{array}{c}0,82 \\
(0,01)\end{array}$ & $0,30 \mathrm{~ns}$ & $\begin{array}{l}-0,76 \\
(0,01)\end{array}$ & $\begin{array}{c}0,68 \\
(0,01)\end{array}$ & $-0,26 \mathrm{~ns}$ & 1 & & & & & & & \\
\hline 14) Instrução & $-0,30 \mathrm{~ns}$ & $-0,23 n s$ & $0,16 \mathrm{~ns}$ & $\begin{array}{r}-0,84 \\
(0,01)\end{array}$ & $\begin{array}{c}-0,67 \\
(0,01)\end{array}$ & $-0,09 \mathrm{~ns}]$ & $\begin{array}{c}0,75 \\
(0,01) \\
\end{array}$ & $\begin{array}{c}0,81 \\
(0,01)\end{array}$ & $0,29 \mathrm{~ns}$ & $\begin{array}{c}-0,76 \\
(0,01)\end{array}$ & $\begin{array}{c}0,70 \\
(0,01)\end{array}$ & $-0,30 \mathrm{~ns} \mid$ & $\begin{array}{c}0,97 \\
(0,01) \\
\end{array}$ & 1 & & & & & & \\
\hline 15) Lixo & $-0,18 \mathrm{~ns}$ & $-0,17 \mathrm{~ns}$ & $-0,03 \mathrm{~ns}$ & $\begin{array}{c}-0,56 \\
(0,01)\end{array}$ & $\begin{array}{c}-0,50 \\
(0,01)\end{array}$ & $0,07 \mathrm{~ns}$ & $\begin{array}{c}0,47 \\
(0,01) \\
\end{array}$ & $\begin{array}{c}0,52 \\
(0,01)\end{array}$ & $0,29 \mathrm{~ns}$ & $\begin{array}{c}-0,42 \\
(0,05) \\
\end{array}$ & $0,22 \mathrm{~ns}$ & $-0,04 \mathrm{~ns}$ & $\begin{array}{c}0,52 \\
(0,01)\end{array}$ & $\begin{array}{c}0,51 \\
(0,01) \\
\end{array}$ & 1 & & & & & \\
\hline 16) Menor 5 anos & $\begin{array}{c}0,45 \\
(0,01) \\
\end{array}$ & $018 \mathrm{~ns}$ & $|-0,25 \mathrm{~ns}|$ & $\begin{array}{c}0,73 \\
(0,01)\end{array}$ & $\begin{array}{c}0,50 \\
(0,01)\end{array}$ & $-0,06 \mathrm{~ns}$ & $\begin{array}{c}-0,65 \\
(0,01) \\
\end{array}$ & $\begin{array}{c}-0,72 \\
(0,01)\end{array}$ & $-0,18 \mathrm{~ns}$ & $\begin{array}{c}0,66 \\
(0,01)\end{array}$ & $\begin{array}{c}-0,55 \\
(0,01)\end{array}$ & $0,13 \mathrm{~ns}$ & $\begin{array}{c}-0,78 \\
(0,01)\end{array}$ & $\begin{array}{c}-0,77 \\
(0,01)\end{array}$ & $\begin{array}{c}-0,45 \\
(0,01) \\
\end{array}$ & 1 & & & & \\
\hline 17) Proteção & $-0,26 \mathrm{~ns}$ & $-0,12 \mathrm{~ns}$ & $\begin{array}{c}0,37 \\
(0,05) \\
\end{array}$ & $\begin{array}{c}-0,62 \\
(0,01)\end{array}$ & $\begin{array}{c}-0,36 \\
(0,05)\end{array}$ & $-0,24 \mathrm{~ns}$ & $\begin{array}{c}0,61 \\
(0,01) \\
\end{array}$ & $\begin{array}{c}0,70 \\
(0,01)\end{array}$ & $\begin{array}{c}0,34 \\
(0,05) \\
\end{array}$ & $\begin{array}{c}0,58 \\
(0,01)\end{array}$ & $\begin{array}{c}0,48 \\
(0,01) \\
\end{array}$ & $-0,08 \mathrm{~ns}$ & $\begin{array}{c}0,66 \\
(0,01) \\
\end{array}$ & $\begin{array}{c}0,68 \\
(0,01)\end{array}$ & $\begin{array}{c}0,43 \\
(0,01)\end{array}$ & $\begin{array}{c}-0,68 \\
(0,01) \\
\end{array}$ & 1 & & & \\
\hline 18) Renda pcf & $-0,24 n s$ & $-0,19 \mathrm{~ns}$ & $-0,09 \mathrm{~ns}$ & $\begin{array}{c}-0,74 \\
(0,01)\end{array}$ & $\begin{array}{c}-0,74 \\
(0,01)\end{array}$ & $-0,04 \mathrm{~ns}$ & $\begin{array}{c}0,65 \\
(0,01)\end{array}$ & $\begin{array}{c}0,68 \\
(0,01) \\
\end{array}$ & $0,27 \mathrm{~ns}$ & $\begin{array}{c}-0,68 \\
(0,01)\end{array}$ & $\begin{array}{c}0,66 \\
(0,01)\end{array}$ & $-0,23 \mathrm{~ns}$ & $\begin{array}{c}0,91 \\
(0,01)\end{array}$ & $\begin{array}{c}0,84 \\
(0,01)\end{array}$ & $\begin{array}{c}0,44 \\
(0,01)\end{array}$ & $\begin{array}{c}-0,65 \\
(0,01)\end{array}$ & $\begin{array}{r}0,55 \\
(0,01)\end{array}$ & 1 & & \\
\hline 19) Saneamento & $-0,13 \mathrm{~ns}$ & $-0,24 \mathrm{~ns}$ & \begin{tabular}{|c|}
0,33 \\
$(0,053)$ \\
\end{tabular} & $\begin{array}{c}-0,81 \\
(0,01)\end{array}$ & $\begin{array}{c}-0,60 \\
(0,01)\end{array}$ & $-0,04 \mathrm{~ns}$ & $\begin{array}{c}0,65 \\
(0,01) \\
\end{array}$ & $\begin{array}{c}0,68 \\
(0,01)\end{array}$ & $\begin{array}{c}0,42 \\
(0,05)\end{array}$ & $\begin{array}{c}-0,62 \\
(0,01)\end{array}$ & $\begin{array}{c}0,56 \\
(0,01) \\
\end{array}$ & $-0,30 \mathrm{~ns}$ & $\begin{array}{c}0,82 \\
(0,01)\end{array}$ & $\begin{array}{c}0,82 \\
(0,01)\end{array}$ & $\begin{array}{c}0,47 \\
(0,01)\end{array}$ & $\begin{array}{c}-0,65 \\
(0,01)\end{array}$ & $\begin{array}{c}0,65 \\
(0,01)\end{array}$ & $\begin{array}{r}0,66 \\
(0,01) \\
\end{array}$ & 1 & \\
\hline 20) Tipo Domicilio & $0,17 \mathrm{~ns}$ & $0,30 \mathrm{~ns}$ & $-0,05 \mathrm{~ns}$ & $\begin{array}{c}0,69 \\
(0,01) \\
\end{array}$ & $\begin{array}{c}0,63 \\
(0,01)\end{array}$ & $0,03 \mathrm{~ns}$ & $\begin{array}{l}-0,55 \\
(0,01)\end{array}$ & $\begin{array}{l}-0,63 \\
(0,01) \\
\end{array}$ & $\begin{array}{l}-0,33 \\
(0,05)\end{array}$ & $\begin{array}{c}0,57 \\
(0,01)\end{array}$ & $-0,28 \mathrm{~ns}$ & $0,10 \mathrm{~ns}$ & $\begin{array}{l}-0,80 \\
(0,01)\end{array}$ & $\begin{array}{l}-0,72 \\
(0,01)\end{array}$ & $\begin{array}{l}-0,42 \\
(0,05)\end{array}$ & $\begin{array}{r}0,55 \\
(0,01)\end{array}$ & $\begin{array}{l}-0,44 \\
(0,01)\end{array}$ & $\begin{array}{c}-0,73 \\
(0,01)\end{array}$ & $\begin{array}{l}-0,63 \\
(0,01)\end{array}$ & 1 \\
\hline
\end{tabular}




\subsection{Anexo VII - Indicador de saúde da população canina}

Tabela 24: cálculo do indicador de saúde para a população de cães de Recife / PE

\begin{tabular}{lcccc}
\hline Grupo etário & $\begin{array}{c}\text { Média de idade } \\
\text { (em meses) dos } \\
\text { animais na faixa } \\
\text { etária }\end{array}$ & $\begin{array}{c}\text { Mortalidade } \\
\text { proporcional }\end{array}$ & Peso & $\begin{array}{c}\text { Cálculo do } \\
\text { Indicador }\end{array}$ \\
\hline 0 a 3 meses & 2 & & & \\
4 a 11 meses & 6 & 34 & -4 & -135 \\
1 a 3 anos & 23 & 27 & -3 & -82 \\
4 a 6 anos & 59 & 23 & -2 & -46 \\
7 a 9 anos & 94 & 5 & -1 & -5 \\
10 a 12 anos & 124 & 5 & 2 & -9 \\
13 ou mais anos & 208 & 3 & 3 & 8 \\
\hline
\end{tabular}

* obs: valores na tabela estão arredondados 


\subsection{Anexo VIII - Metas educacionais e sociais estabe/ecidas para o projeto}

$\mathrm{O}$ autor do presente trabalho considera que outros propósitos além dos objetivos cientificos, devem permear as metas de um projeto de pesquisa. Por este motivo, relata aqui intenções e realizações com as quais se procurou conferir traços educacionais e sociais às diversas atividades relacionadas ao projeto "Dinâmica Populacional e Raiva Canina na Cidade de Recife".

Durante a realização do projeto integrado, o qual foi fomentado pela PCR / SS / CVA e FACEPE, foram promovidas ações educativas e de divulgação do estudo, como a distribuição de folhetos aos entrevistados e envio de textos aos jornais, participação em programa interativo de rádio AM e participação em diversas mesas redondas com profissionais ligados à prática de saúde pública e medicina veterinária, além de reuniões técnicas com representantes de órgãos oficiais, do estado de Pernambuco e também do Ceará.

A experiência desenvolvida em Recife foi, ainda, apresentada e discutida na Reunião Nacional dos Coordenadores Estaduais de Zoonoses, promovida pela Coordenação Nacional de Controle de Zoonoses e Animais Peçonhentos / FNS em São Paulo, no mês de abril de 1998, podendo vir a contribuir para a definição de diretrizes e politicas de controle da raiva na região Nordeste.

Também foram apresentadas palestras e trabalhos nas seguintes reuniões: encontro comemorativo dos $\mathbf{9 5}$ anos do Instituto Pasteur de São Paulo (julho de 1998); Congresso Latino-americano de Bem Estar Animal (São Paulo, outubro de 1998); Congresso Brasileiro de Zoonoses (Vitória / ES, novembro de 1998); e "IX Reunion internacional sobre avances en la investigacion y control de la rabia en las americas", promovida pela OPS (México, dezembro de 1998).

Uma dos principais objetivos estabelecidos inicialmente, e considerado de grande relevância, foi a formação de recursos humanos. Atualmente, médicos veterinários são contratados pelos serviços de saúde pública estadual e municipais, geralmente sem qualquer treinamento e com inadequada formação para atividades de saúde pública. 
Dentre os profissionais que participaram das reuniões de treinamento para o projeto, três deles se vincularam ao curso de residência em saúde pública junto ao Núcleo de Estudos em Saúde Coletiva / Fiocruz / Recife. Dois deles realizaram estágio supervisionado obrigatório (ESO) dentro das atividades do projeto, e outros dois realizaram ESO em atividades de saúde pública após a conclusão das atividades de campo. Grande parte continuou envolvida com atividades de saúde pública. Este é sem dúvida alguma um dos aspectos mais positivos relacionados direta ou indiretamente ao projeto, já que sem estímulo as vocações e interesses não são despertados.

No âmbito do Departamento de Medicina Veterinária da UFRPE, a realização do projeto ajuda a fortalecer as atividades de Saúde Pública Veterinária, até então desprestigiadas. É importante a consolidação de uma linha de pesquisa em Saúde Pública na UFRPE, com possibilidades de capacitação e treinamento de estudantes a nivel de graduação, quer em estágios ou atividades de iniciação científica, e também estudantes de pós-graduação, no curso de Mestrado atualmente existente e também no curso de Doutorado em processo de criação.

Sob a influência deste, teve início o planejamento da criação de um Núcleo de Saúde Pública Veterinária na UFRPE, com propósitos diversos, dentre eles o estímulo à profissionalização em atividades de Saúde Pública Veterinária. Plano que se espera concretizar.

Finalmente, procurou-se ajudar a consolidar o relacionamento já existente entre o Departamento de Medicina Veterinária da UFRPE e as instituições de saúde pública federais, estaduais e municipais, com vantagens para o pleno desempenho dos diferentes papéis institucion ais, almejando benefícios à saúde coletiva em Recife e no estado de Pernambuco. 